\title{
Os jovens e a História Brasil e América do Sul
}

\author{
Luis Fernando Cerri (org.)
}

CERRI, L.F., ed. Os jovens e a História: Brasil e América do Sul [online]. Ponta Grossa: Editora UEPG, 2018, 332 p. ISBN: 978-85-7798-248-6. https://doi.org/10.7476/9788577982486.

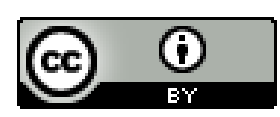

All the contents of this work, except where otherwise noted, is licensed under a Creative Commons Attribution $\underline{4.0 \text { International license. }}$

Todo o conteúdo deste trabalho, exceto quando houver ressalva, é publicado sob a licença Creative Commons Atribição 4.0.

Todo el contenido de esta obra, excepto donde se indique lo contrario, está bajo licencia de la licencia Creative Commons Reconocimento 4.0. 


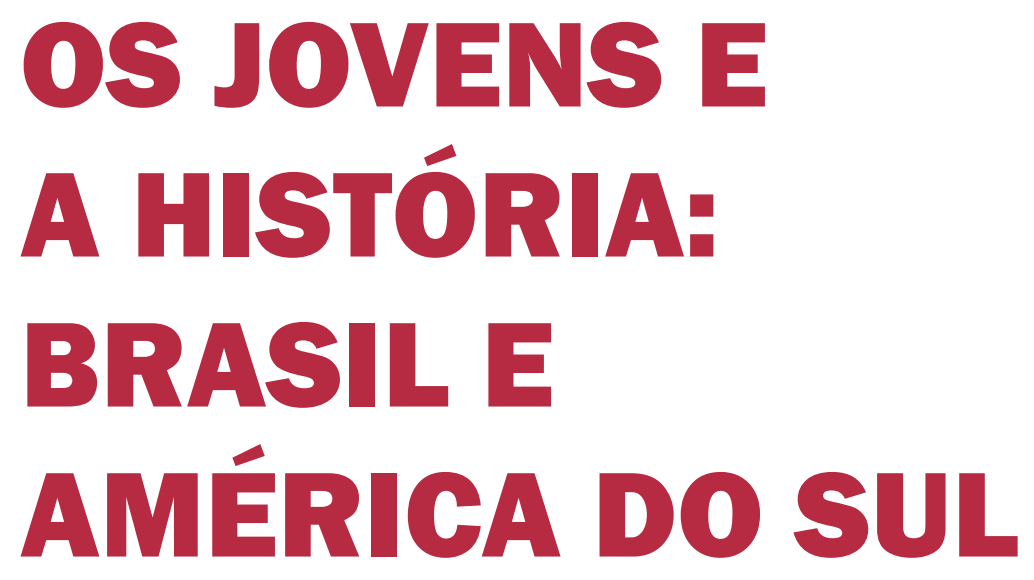




\title{
UNIVERSIDADE ESTADUAL DE PONTA GROSSA
}

\author{
REITOR EDITORA UEPG \\ Carlos Luciano Sant’Ana Vargas Lucia Cortes da Costa \\ VICE-REITORA CONSELHO EDITORIAL \\ Gisele Alves de Sá Quimelli Lucia Cortes da Costa (Presidente) \\ Augusta Pelinski Raiher \\ PRÓ-REITORA DE EXTENSÃo Bruno Pedroso \\ E ASSUNTOS CULTURAIS Dircéia Moreira \\ Marilisa do Rocio Oliveira Ivo Mottin Demiate \\ Jefferson Mainardes \\ Jussara Ayres Bourguignon \\ Marilisa do Rocio Oliveira \\ Silvio Luiz Rutz da Silva
}


LUIS FERNANDO CERRI (org.)

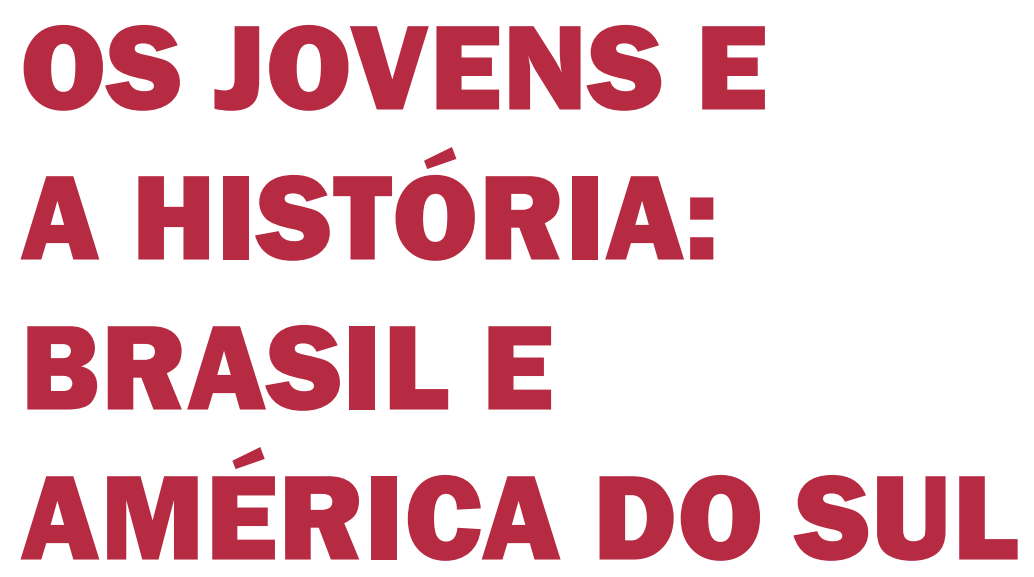

Editora

UEPG 


\title{
Copyright @ by Luis Fernando Cerri Org. \& Editora UEPG
}

Nenhuma parte deste livro, sem autorização prévia por escrito da Editora, poderá ser reproduzida ou transmitida, sejam quais forem os meios empregados: eletrônicos, mecânicos, fotográficos, gravação ou quaisquer outros.

\author{
Equipe Editorial \\ Coordenação editorial Lucia Cortes da Costa \\ Revisão de Português Elita Medeiros \\ Imagem capa Waldece Wagner Alexandre de Sousa \\ Capa, Projeto gráfico e Diagramação $\quad$ Marco Wrobel
}

Ficha Catalográfica Elaborada por Maria Luzia Fernandes Bertholino dos Santos - CRB 9/986

J86 Os jovens e a História: Brasil e América do Sul/ Luis Fernando Cerri (Org.). Ponta Grossa: Ed. UEPG, 2018.

332 p.; il.

ISBN: 978-85-7798-236-3

1. História- América Latina. 2. Jovem- consciência histórica. 3. Jovem - cultura histórica. 4. Jovem - Cultura política. 5. Identidade. I. Cerri, Luis Fernando (Org.). II. T.

CDD: 980

Depósito legal na Biblioteca Nacional

Editora filiada à ABEU

Associação Brasileira das Editoras Universitárias

\section{Editora UEPG}

Praça Santos Andrade, n. 1

84010-790 - Ponta Grossa - Paraná

Fone: (42) 3220-3306

e-mail: vendas.editora@uepg.br 


\section{SUMÁRIO}

Apresentação

Jovens do Mercosul e suas ideias sobre presente, passado e

futuro: notas sobre a formação de sentido histórico 15

Cristiani Bereta da Silva e Luciana Rossato

Concepções de ensino e aprendizagem de História entre jovens estudantes de Florianópolis/SC

Nucia Alexandra Silva de Oliveira

Ensino de História e formação para a cidadania: reflexões sobre a intencionalidade no ensino de História como elemento de formação histórica, política e cidadã.

Marizete Lucini

Sentidos da História atribuídos por jovens em diálogo com aspectos de uma cultura política e histórica emergentes

na cultura escolar 85

Lana M. de C. Siman, Herbert de Oliveira Timóteo, João Andrade e

Mariano A. Diniz Filho

Quais são os sentidos da História? De como alguns jovens latino-americanos avaliaram fatores de mudança na História recente 115

Caroline Pacievitch

Representações de estudantes sobre heróis nacionais:

histórias conectadas de Argentina, Brasil, Chile e Uruguai

Flávia Eloisa Caimie Letícia Mistura

Heróis velhos em uruguaios jovens

Federico Alvez Cavanna e Gabriel Quirici

Jovens, identidade e consciência da integração latino-americana... 187

Léia Adriana da Silva Santiago

América Latina, identidade latino-americana e ideologia neoliberal.. 211 Wilian Carlos Cipriani Barom 
Pensar e viver a História nas fronteiras: os jovens, a história (ensinada) e as imagens sobre o continente americano no contexto mato-grossense 259

Renilson Rosa Ribeiro, Luís César Castrillon Mendes e

Osvaldo Rodrigues Junior

0 que todo estudante de História gostaria que seu professor soubesse, mas tinha medo de dizer.

Luis Fernando Cerri

Apêndice A - Amostra detalhada por cidade ...................................... 299

Apêndice B - Questionários .............................................................. 317

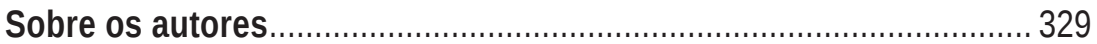




\section{APRESENTAÇÃO}

Parece um truísmo dizer que esta é uma obra coletiva. Para ser justo, os resultados de pesquisa em forma de livro que chegam ao leitor, neste momento, tensionam e esgarçam a definição de coletivo. Mal é possível entrever, por entre as centenas de páginas desta obra, as milhares de horas de trabalho e as centenas de pesquisadores envolvidos, desde o surgimento da ideia, passando pela produção, distribuição, aplicação, devolução, tabulação dos dados, discussões, estudos, encontros, escrita, revisão, até chegar, finalmente, ao livro que aqui se apresenta.

A pesquisa buscou identificar e analisar, comparativamente, elementos de cultura histórica, cultura política e consciência histórica de jovens estudantes entre 15 e 16 anos no Brasil e em outros quatro países da América do Sul. A metodologia consistiu na análise estatística aplicada às Ciências Humanas de dois bancos de dados, produzidos a partir das respostas de milhares de estudantes e centenas de professores de História a um extenso questionário para cada grupo, aplicado entre agosto de 2012 e maio de 2013. O estudo permitiu a produção de reflexões no campo da Teoria da História, consideradas as condições sociais de produção, circulação e uso do conhecimento histórico enquanto questões atinentes à teoria, segundo a formulação de Klaus Bergmann (1989/1990). São contempladas, ainda, as dimensões da formação do profissional de História, tanto pensando o ambiente cultural que condiciona a sua formação e interesses como historiador, quanto sua condição de professor, através dos questionários para esse grupo. Em suma, não sendo um projeto de produção de historiografia usual, baseado no estudo de fontes primárias que remetem ao passado, constitui um esforço de produção teórica em História também de modo pouco usual, baseado em material empírico consistente, que informa uma história recente do pensamento histórico na sociedade, preocupado com as dimensões do ensino e da aprendizagem, e o papel do historiador nesse quadro.

A inspiração clara deste trabalho encontra-se em um projeto de pesquisa desenvolvido na Europa nos anos 1990, intitulado Youth and 
History, sobre a aprendizagem e a consciência histórica dos jovens (ANGVIK; BORRIES, 1997) baseado em três grandes temas/categorias-chave: a) o estado atual do Ensino de História e os resultados da aprendizagem histórica; b) a consciência histórica dos jovens; e c) a cultura política dos jovens e seus professores. O projeto foi desenvolvido nos países europeus a partir de 1994, com base na rede European Standing Conference of History Teachers Associations, e procurou dar respostas a esse tipo de questão com um estudo comparativo de amplo alcance, baseado em um questionário respondido por jovens de 15 anos de 25 países europeus, mais Israel e Palestina, e seus professores de História, versando sobre conteúdos, métodos e concepções de História e cidadania, com sustentação no conceito de consciência histórica. Esta pode ser definida sumariamente como "o grau de consciência da relação entre o passado, o presente e o futuro" (ANGVIK; BORRIES, 1997, p. 403), embora uma descrição mais detida do conceito seja necessária para que se embase uma proposta metodológica, o que tem sido feito por diversos autores. Para Rüsen (2001), a consciência histórica inclui as operações mentais (emocionais e cognitivas, conscientes e inconscientes), através das quais o tempo experienciado em forma de memória é usado como meio de orientação na vida diária. O levantamento europeu conseguiu em torno de 31.000 respondentes. A pesquisa constituiu-se da elaboração, aplicação e tabulação de um questionário para estudantes e outro para professores, definido após várias reuniões entre as dezenas de pesquisadores de toda a Europa, liderados por Magne Angvik e Bodo von Borries (1997).

Seguindo a estratégia da pesquisa europeia, os questionários utilizados na presente investigação organizaram vários temas, que se desdobraram em afirmações, às quais os estudantes responderam assinalando um dos itens da escala Likert de valoração (de concordo totalmente a discordo totalmente, passando por concordo, indeciso e discordo ou seus equivalentes). Os estudantes responderam, além de informações para contextualizar cada indivíduo, sobre a sua concepção da história e a importância que a ela conferem, credibilidade em fontes de conhecimento histórico, descrição e aproveitamento das aulas de história assistidas, concepções de futuro, conhecimentos cronológicos, interesse por períodos da História, assuntos 
ou temas históricos, conhecimento e avaliação de fatores de mudanças históricas atuais e futuras, avaliação e imagens atribuídas aos períodos e personagens da história, atribuição de causas às mudanças, expectativas de futuro pessoal e de futuro, motivos da divisão das sociedades em classes, perguntas de reações pessoais caso vivesse situações do passado (como casamentos forçados, por exemplo), fatores de composição da nacionalidade e da soberania sobre um território, preservação de patrimônio histórico, conceitos de nação, posicionamentos políticos controversos quanto a questões prementes nos países ou no continente. Os professores responderam a questões de contextualização do indivíduo nos países, de formação acadêmica, experiência docente em anos, particularidades curriculares no ensino da História, avaliação da capacidade intelectual dos estudantes, significado de religião e de política para a vida cotidiana do professor, seu posicionamento político, períodos da História enfatizados, conceitos mais importantes ensinados, métodos de ensino-aprendizagem, objetivos do ensino da História, interesse dos estudantes, principais problemas do ensino de História no país segundo a visão do professor, fatores de mudança histórica que consideram mais relevantes e projeção de futuro quanto a fatores de mudança histórica. Destaque-se que algumas das questões foram idênticas às do instrumento para os estudantes, o que permitiu diversas análises comparativas.

Os instrumentos que geraram as bases de dados usados nesta pesquisa resultaram de uma adaptação dos questionários europeus às necessidades sul-americanas. A manutenção de boa parte das questões está inserida dentro da prática científica de replicação das pesquisas em outros contextos, embora não se trate, aqui, de buscar validar a pesquisa europeia, dada a distância cronológica e geográfica das amostras, embora sejam possíveis algumas colaborações quanto ao método, diante dos objetivos estabelecidos. Em geral, as perguntas elaboradas para o estudo europeu mantêm sua validade e interesse para a investigação proposta para os países envolvidos. No que se refere às diferenças entre os questionários, foram eliminadas questões que faziam pouco sentido para o novo contexto. Foram retiradas, por exemplo, questões referentes a conflitos étnicos ou de imigração 
recente, mudanças nos países socialistas do Leste Europeu, pagamento de reparações a ex-colônias ou referências ao processo colonizador sob a perspectiva das metrópoles, assim como questões que se referiam a um passado ausente na América (como igrejas medievais). Por outro lado, foi incluída uma série de questões pertinentes para nosso contexto, mas não contempladas satisfatoriamente no questionário europeu, das quais as perguntas sobre heróis nacionais, as ditaduras militares e o papel das mulheres são os exemplos mais destacados.

A reforma dos questionários ocorreu uma primeira vez em 2007, momento inicial do projeto piloto, em uma sessão de trabalhos de dois dias inteiros no Brasil, com a presença do professor Gonzalo de Amézola e dos membros do Grupo de Estudos em Didática da História (GEDHI). Houve um esforço para fazer com que as perguntas tomadas do questionário europeu (para o qual se utilizou a versão portuguesa publicada por PAIS, 1999) fossem modificadas para atender nossos interesses de investigação, mas para que também tivessem sentido para os professores e alunos dos países envolvidos no projeto piloto (inicialmente apenas Brasil e Argentina, com a agregação subsequente de uma amostra uruguaia), de acordo com nossas experiências como docentes. Para tanto, foi feita uma tradução do português de Portugal para o português do Brasil, bem como adaptados termos e exemplos para maior compreensibilidade dos enunciados para o público-alvo.

Terminada a pesquisa piloto, o questionário foi revisto a partir da avaliação da primeira experiência, novamente em uma reunião no Brasil, com a participação do coordenador geral e do GEDHI, bem como do Prof. Amézola (Argentina), o Prof. Gabriel Quirici (Uruguai), o Prof. Luis Caputo (Paraguai) e o Prof. Ramón Casanova (Venezuela), em uma reunião de três dias, em Ponta Grossa - PR, em julho de 2011. A partir da nova conformação dos instrumentos, as traduções para o espanhol procuraram dar conta das especificidades linguísticas e culturais de cada um dos países envolvidos: Argentina, Uruguai, Paraguai, Chile e Venezuela. Por motivos alheios à vontade dos pesquisadores, a amostra da Venezuela nunca chegou a ser coletada. 
No Apêndice A estão disponíveis os questionários para estudantes e para professores, em sua versão em português, na forma exata em que foram aplicados, incluindo os erros de digitação, numeração, etc.

A amostra elaborada é não probabilística, ou seja, não é estatisticamente representativa, mas construída segundo um desenho que permite conclusões significativas pelo tamanho da amostra. Em outros termos, as suas conclusões só podem ser generalizadas para a própria amostra (cerca de 4 mil questionários de alunos e 300 de professores), embora as dimensões atingidas permitam considerar que é bastante provável que se aproximem dos dados que obteríamos caso fosse feita uma amostra probabilística.

Esta opção facilitou a coleta de dados e a viabilidade financeira da pesquisa, pois os dados foram coletados onde havia parcerias disponíveis, não sendo necessário usar critérios de aleatoriedade (sorteio, etc.). Entre as desvantagens, não é possível generalizar os resultados para todo o universo pesquisado (não podemos afirmar, por exemplo, que as conclusões são válidas para todos os estudantes da mesma idade em Ponta Grossa, ou do Amazonas, ou do Uruguai, respectivamente), e não é possível estabelecer margens de erro.

Em cada escola selecionada aplicou-se o questionário durante uma aula de História, e a maioria dos alunos precisou de em torno de 45 minutos para respondê-lo. Responderam o questionário alunos de 15 a 16 anos, com os questionários colhidos em uma única sala de aula. Esta opção de idade refere-se a um esforço de uniformização mínima de respondentes, alunos que estejam no final de sua escolarização obrigatória e já tenham acesso à maioria dos conteúdos escolares de História.

No caso do Brasil, em que a amostra foi mais ampla, não foram computados os questionários com respondentes com menos de 15 ou mais de 16 anos. Nos outros países, todos os questionários foram incluídos; os que estão fora da faixa etária serão utilizados apenas em análises nacionais. Entre professores, aplicou-se o questionário ao docente da turma em que se aplicam os questionários para alunos, e mais dois professores de História da mesma escola, sempre que possível. 
Em cada estado brasileiro buscou-se que os questionários fossem coletados em até 3 tipos de cidades: grande (capital nacional, que é a referência administrativa, econômica e social para o país), média (capitais regionais, consideradas polo regional em seu estado e regiões de estados vizinhos) e pequenas (com menos de 50 mil habitantes e que são referência, no máximo, para poucas cidades vizinhas menores). Em cada cidade participante do projeto foram abordadas 7 escolas, sempre que possível, conforme a descrição a seguir:

- Escola pública de excelência -mantida pelo poder público municipal, estadual ou federal, posicionada entre as melhores públicas do município no ranking do ENEM de 2010 ou 2011 (www.inep.gov.br), geralmente caracterizada por exame de admissão;

- Escola pública central - a referência é geográfica: trata-se de uma escola pública comum, que se localiza no centro da cidade ou bastante próxima a ele, independente de quem são seus principais frequentadores;

- Escola pública de periferia - referências geográfica e social: trata-se de uma escola pública em um bairro distante do centro e geralmente habitado por pessoas de renda baixa;

- Escola rural - geralmente pública, não há problema se a mantenedora for privada, caracteriza-se por se localizar fora da área urbana, embora possa estar em distritos ou bairros rurais, seu principal público é o de filhos de trabalhadores em atividades do setor primário da economia: agricultura, pecuária, pesca, atividades extrativistas ou mineração;

- Escola privada laica - caracteriza-se por ser mantida por instituição privada com objetivo de lucro, em que os alunos pagam pelo serviço educacional que recebem e, por isso, ela também pode ser caracterizada como escola-empreendimento; 
- Escola privada religiosa - caracteriza-se por ser mantida por instituição religiosa, independente da confissão (embora preferencialmente católica, porque se trata da confissão religiosa numericamente mais expressiva), em que seja bastante provável encontrar alunos cujos pais professam a mesma fé da instituição mantenedora;

- Escola privada alternativa - trata-se de escola cooperativa de professores e/ou pais, ou que foge do padrão empresarial em favor de uma pedagogia alternativa ou experimental.

Nem sempre uma cidade teve todos os tipos de escolas listadas acima. Nesse caso, não se coletaram dados em duas escolas de mesmo tipo. Omitiuse ou foi feita a coleta em uma cidade de mesmo tipo que tinha aquele de escola faltante. Por exemplo, em cidades pequenas, escolas particulares em município próximo de mesmo perfil e, no caso de capitais conurbadas, escolas rurais em um município da conurbação.

Por se tratar de uma pesquisa quantitativa na área de Ciências Humanas, a discussão sobre ética em pesquisa quanto a essa especificidade ainda é incipiente. Os dados não são conhecidos ou trabalhados por um sujeito particular, mas pela base de dados em que o interesse é dado pelo aspecto coletivo. Mesmo assim, alguns cuidados quanto a esse aspecto foram tomados: nenhum dos participantes foi identificado pessoalmente, e nenhuma das escolas participantes foi identificada nominalmente. Os pesquisadores asseguraram o anonimato a todos os respondentes, orientando para que não se identificassem no questionário e informando que, caso não permitissem a utilização dos seus dados coletados na pesquisa, não deveriam responder ao questionário, pelo que todos os participantes ficaram à vontade para responder ou não. No Apêndice B deste livro está disponível uma tabela detalhada com o desenho da amostra.

Os temas da base de dados permitiram diversos estudos, tanto no que se refere a cada uma das variáveis consideradas, quanto no que tange ao cruzamento entre elas, e ainda a criação de construtos de segunda ordem ou índices. As variáveis envolvem informações dos sujeitos pesquisadores referentes à História ensinada, aos dados sobre o pensamento dos jovens (a 
próxima geração politicamente ativa no MERCOSUL) quanto aos sistemas políticos, hierarquização de grupos de solidariedade e visão dos outros países e, ainda, as suas formas de conceber a identidade pessoal e coletiva no tempo, de modo a traçar planos de ação de curto, médio e longo prazo (ou seja, sua consciência histórica em ação). Os impactos e benefícios esperados a partir dos resultados que agora apresentamos envolvem a produção de conhecimento para subsidiar políticas públicas nos países envolvidos (por exemplo, no que se refere a currículos e programas, livros e outros materiais didáticos, campanhas educativas e outras), como para fornecer elementos passíveis de utilização por professores nas escolas e para formadores de professores, nas faculdades e universidades, orientando e otimizando os esforços educacionais. Este último propósito, relevante em todos os países é, também, urgente no Brasil, diante da necessidade de problematizar o ensino de História em particular e as humanidades no caso geral, em um momento em que os métodos avaliativos do ENEM se apresentam como uma nova baliza de organização curricular. Dados que se preocupem com um estudo de caso brasileiro se fazem mais prementes para problematizar as escolhas deste processo. Trata-se, enfim, de um livro destinado a professores de História e gestores da Educação, diante da necessidade cada vez mais premente de conhecer, com mais e mais profundidade, nosso interlocutor, o estudante.

\section{REFERÊNCIAS}

ANGVIK, Magne; BORRIES, Bodo von (eds.) Youth and History. A comparative European survey on historical consciousness and political attitudes among adolescents. Hambourg: Edition Körber-Stiftung, 1997. Vol. A.

BERGMANN, Klaus. A história na reflexão didática. São Paulo. Revista Brasileira de História, v.9, n. 19, p. 29 - 42, set 1989/fev. 1990.

PAIS, José Murilo. Consciência histórica e identidade. Oeiras: Celta, 1999. RÜSEN, Jörn. Razão histórica. Fundamentos da ciência histórica. Brasília. UNB. 2001. 


\section{JOVENS DO MERCOSUL E SUAS IDEIAS SOBRE PRESENTE, PASSADO E FUTURO: NOTAS SOBRE A FORMAÇÃO DE SENTIDO HISTÓRICO}

Cristiani Bereta da Silva

Luciana Rossato

\section{INTRODUÇÃO}

Analisamos, neste capítulo, questões sobre a formação de sentido histórico por meio das respostas dadas por jovens brasileiros, uruguaios, argentinos, paraguaios e chilenos, com idade entre 15 e 16 anos, às perguntas relacionadas ao tempo e à História. Mesmo com idades tão próximas, os jovens, aos quais nos referimos, são bastante diferentes, uma vez que são de países, culturas, escolas diversas. Não obstante a isto, observa-se que possuem uma característica comum: são todos estudantes. Para este capítulo, privilegiamos as respostas dadas por estes estudantes a 9 questões (PROYECTO ZORZAL, [s.d.]) específicas, entre as 43 questões do questionário aplicado na pesquisa. Recortamos essas perguntas, pois nosso interesse é identificar como a noção de futuro aparece nas respostas dos estudantes em suas relações com o passado e com o presente e, a partir de então, problematizar questões sobre a consciência histórica e a formação de sentido histórico desses jovens.

O universo abordado trata de uma amostra que não é probabilística, nem estatisticamente representativa dos jovens do Mercosul. Isto significa que, muito embora a pesquisa lide com quase 4 mil respostas, as análises não podem servir a generalizações. Contudo, justamente porque lidam com um universo tão amplo, podem contribuir para estudos e reflexões sobre os jovens e suas ideias históricas; no limite, também podem fornecer pistas sobre a formação de sentido histórico. O trabalho com dados quantitativos, no campo da História, ainda causa desconfianças e estranhamentos entre os pares, que chamam a atenção para os limites do alcance de algumas análises construídas por meio de dados matemáticos. Defendemos, 
contudo, que o trabalho com dados probabilísticos tem potencialidades e desafios, tanto quanto outros métodos de pesquisa, que se utilizam de outras linguagens que não a matemática. Abordagens de amplo espectro - como a da pesquisa citada - podem contribuir para uma aproximação da realidade observada, conquanto que saibamos que nunca serão suficientes para a compreensão dessa mesma realidade. Mas esses limites e desafios também estão presentes em outras abordagens consideradas qualitativas, como bem pontuam Maria Cecília Minayo e Odécio Sanches (1993), sobre o tratamento quantitativo e qualitativo nas pesquisas.

Sobre esse ponto, também acompanhamos Luis Fernando Cerri (2014), em sua defesa da possibilidade de captar evidências sobre consciência histórica em pesquisas que lidam com dados estatísticos. Seu argumento assenta-se no seguinte pressuposto: se a consciência histórica se expressa em narrativas (RÜSEN, 2007, 2009; 2014), é plausível supor que, ao responder uma questão - mesmo que fechada, de um questionário - o sujeito busque referências de narrativas conhecidas para expressar sua opinião. Para Cerri (2014, p. 183), quando o sujeito pesquisado decide diante de uma história e escolhe uma das alternativas apresentadas, ele "permite que o observador entreveja o exato momento em que a orientação temporal da consciência histórica atua, estabelecendo o elo dinâmico entre o passado que experienciou e o futuro que projeta, na ação que escolhe". Se concordamos que, mesmo se diferenciando em aspectos importantes, a "consciência histórica é uma forma específica de memória histórica” (RÜSEN, 2009, p. 168), e se assumimos o pressuposto que ela está "estreitamente ligada com a memoração" (RÜSEN, 2014, p. 99); ou seja, com o ato de lembrar, é válido supor que é na sua experiência de vida, na interpretação de narrativas, na percepção e orientação temporal, bem como de pertencer a um coletivo, que o sujeito busca elementos para argumentar ou atribuir resposta a uma pergunta feita. Nesta clave, consciência histórica é constituição de sentido sobre a experiência do tempo, e é inseparável da formação histórica. Formação tomada, aqui, como competências acionadas pelo sujeito para interpretar o mundo em que vive e a si próprio, articulando "o máximo de orientação do agir com o máximo de autoconhecimento, possibilitando 
assim o máximo de auto-realização [sic] ou de reforço identitário" (RÜSEN, 2007, p. 95).

A discussão sobre a consciência histórica e a formação de sentido histórico inclui, necessariamente, pensar tanto "nos modos de representação que dão ao passado a forma distintiva de história" (RÜSEN, 2009, p. 168), como no inter-relacionamento do passado, presente e futuro contidos nessa mesma representação. A relação temporal é sempre mediada, quando se trata de consciência histórica, pois esta significa a compreensão da experiência do tempo para a interpretação do presente e a orientação para o futuro.

A abordagem sobre o tempo é irrenunciável na discussão proposta, e implica um diálogo não apenas com a didática da História, também com a filosofia da História. A didática da História, tomada com base nos estudos de Rüsen (2007) e Bergmann (1990), constitui parte indissociável da teoria da História. A didática da História estuda não apenas a realidade escolar, também os processos e funções da consciência histórica elaborados pelos sujeitos a partir de orientações formais e escolares, bem como informais e extraescolares. A teoria da História e a didática convergiriam quanto às operações e aos processos existenciais da consciência histórica, sendo elaboradas, porém, de maneiras distintas. Para Klaus Bergmann (1990, p. 30-32), as pesquisas orientadas desse campo devem incluir, entre os objetos de suas investigações, as recepções extraescolares ou extracientíficas de história, que atravessam o cotidiano e constituem o vivido dos indivíduos das mais diferentes formas. Entre esses objetos, que possuem seus efeitos para a formação histórica, estão a televisão, o cinema, a imprensa, as conversas cotidianas, os museus, a literatura histórica, as propagandas históricas, as representações científicas e populares sobre o passado, os livros didáticos, os monumentos, os edifícios e nomes de ruas que lembram eventos históricos, entre outros.

A filosofia da História fornece princípios importantes para a compreensão do tempo na configuração da existência. Para Paul Ricoeur (2007), a temporalidade constitui a característica principal do ser que somos, assinalando distinções no modo de ser que somos a cada vez, nas maneiras de surgir nos cenários do mundo, de existir e habitar esses mundos de 
diferentes formas. A partir do diálogo estabelecido com Heidegger em Ser e Tempo, Ricoeur (2007) discute sobre os três modos de temporalização e as perspectivas inéditas que essa forma de ordenar a experiência temporal abriria para o confronto entre a filosofia e a epistemologia da História. $\mathrm{Na}$ tripartição proposta por Heidegger, temporalidade (orientação para o futuro), historicidade (o intervalo que se estende ou que se estica entre um acontecimento e outro), intratemporalidade (evidenciaria a preocupação com o presente), Ricoeur (2007) vê a preocupação com o futuro como fundamental, mesmo que não possa prescindir da correlação dos três níveis. O futuro, nesse processo, teria função preponderante, posto que seria a relação com o futuro que induziria a sequência das outras determinações temporais da experiência histórica. Encetando diálogo também com Koselleck, sobre o "horizonte de expectativa e espaço de experiência", Ricoeur (2007, p. 374) destaca que a noção "de estar em dívida" seria o "conceito ponte", o elo entre futuridade e preteridade, pois "a resolução antecipadora só pode ser um assumir a dívida que marca nossa dependência do passado em termos de herança." Se a ideia de futuro é marca indelével na configuração do sentido da existência humana, não seria diferente na configuração da consciência histórica, que "sempre tem o futuro como ponto de referência” (RÜSEN, 2014, p. 97), mesmo que sua função orientadora ocorra a partir da experiência do passado. Isto porque ela está sempre em processo de imbricamento do "horizonte de experiência, no qual o passado está presente de diferentes modos, e o horizonte de expectativa, no qual o agir (e o sofrer) se projeta(m) de modo finalista" (RÜSEN, 2014, p. 97). A orientação para o passado da consciência histórica estaria constantemente provendo esse direcionamento com expectativas normativamente carregadas, ou seja, com orientação para o futuro. A expectativa da discussão que propomos é justamente pensar o futuro acionado nas respostas desses jovens e, assim, compreender a própria relação que essa geração estabelece com as temporalidades.

\section{JOVENS: ALGUMAS QUESTÕES}

Quem são os jovens que responderam aos questionários? Quais as características desse grupo de indivíduos, que são identificados como jovens 
e/ou adolescentes ${ }^{1}$ ? Este grupo é visto de modo homogêneo, se considerado a partir do recorte de idade, mas é marcado por heterogeneidade, se for analisado a partir da composição dos indivíduos, devido as suas características socioeconômicas, de gênero e étnico-raciais. Pierre Bourdieu (1983, p. 2) escreve que a

idade é um dado biológico socialmente manipulado e manipulável; e que o fato de falar dos jovens como se fossem uma unidade social, um grupo constituído, dotado de interesses comuns, e relacionar estes interesses a uma idade definida biologicamente já constitui uma manipulação evidente.

Os estudos sobre juventude salientam que este conceito é marcado pela imprecisão e ambiguidade. Apesar de um dos ordenadores sociais ser a idade (junto com o sexo), este grupo não pode ser definido somente por este aspecto. Infância, juventude e velhice são recortes imprecisos, que variam conforme o contexto histórico, e são marcados por grandes diferenças, conforme a classe, o gênero, a religião e a etnia. Juventude é um conceito que pode ser definido como uma etapa da vida (de preparação, no qual, aos jovens, é permitida uma indefinição não permitida em outros períodos etários), como um período de moratória e, também, por seu valor simbólico ou como um produto (MARGULIS; URRESTI, 1996).

Os jovens que estamos analisando constituem um grupo que, além de terem a mesma idade, têm sua identidade marcada por outra característica comum: todos são estudantes, uma vez que a pesquisa foi realizada em escolas no Brasil e em outros países do Mercosul. No entanto, apesar destes dois aspectos, este grupo é heterogêneo, pois a pesquisa foi realizada

\footnotetext{
${ }^{1}$ A juventude e a adolescência, apesar de muitas vezes tratadas como sinônimos, diferenciam-se de acordo com definições de faixa etária, representação social e áreas de conhecimento. O termo adolescente foi definido a partir dos estudos sobre as transformações biológicas e psicológicas pelas quais passam os indivíduos entre os 12 e 18 anos de idade. Este termo, forjado pela Biologia e Psicologia, acabou se difundindo entre os educadores. Já o termo jovens/juventudes é analisado a partir do olhar sociológico e histórico, e tem como foco as características socioeconômicas e culturais. Existem variados recortes etários para estabelecer uma faixa da população como jovem. A OMS e a UNESCO adotam o recorte de 15 a 24 anos. Tal recorte foi convencionado em 1964, na Conferência de Grenoble, baseando-se em dois limites: a) idade mínima para adentrar no mercado de trabalho; b) expectativa para a conclusão da escolarização formal. Porém, mais recentemente, alguns países, incluindo o Brasil, através da SNJ e do CONJUV, adotaram um recorte mais extenso: 15 a 29 anos (Lei 12.852/2013, BRASIL, 2013). Já a adolescência é reconhecida, tanto por órgãos internacionais como pelo governo brasileiro, como perfazendo o intervalo entre os 12 e os 18 anos. A lei no 8.069, de 13 de julho de 1990 (BRASIL, 1990), criou o ECA, legislação para menores de idade em vigor no Brasil.
} 
em diferentes escolas: públicas e privadas, de municípios grandes, médios e pequenos, centrais e de periferia, laicas e religiosas, além de ter sido realizada em 5 países diferentes. Os estudantes/as pesquisados são jovens que vivenciam esta fase de sua vida de diferentes formas, bem como vivenciam o processo de escolarização de modos diversos. Para Juarez Dayrell (2007), os jovens que chegam às escolas públicas, atualmente, são muito distintos dos jovens de gerações anteriores, uma vez que existem diferentes formas de vivenciar a condição juvenil. Os jovens nascidos na década de 1990 em diante estão inseridos em uma sociedade que ressignifica constantemente sua relação com o tempo e o espaço, devido às transformações decorrentes da difusão do uso da internet.

Outro aspecto a ser considerado é que uma grande parcela dos jovens brasileiros ${ }^{2}$ não usufrui da moratória em relação ao trabalho, o que é muito comum entre os jovens europeus. No entanto, a inserção dos jovens no mercado de trabalho não é fácil, em decorrência das relações precárias de trabalho e dos altos índices de desemprego que afetam, principalmente, aqueles pertencentes às classes populares. Muitos jovens precisam conciliar o estudo e o trabalho, o que afeta sua trajetória educacional, uma vez que a possibilidade de viver a condição juvenil passa pela necessidade de trabalhar para ter acesso ao lazer e ao consumo (DAYRELL, 2007).

O processo de escolarização, no Brasil, tem passado por muitas transformações nas últimas décadas. No decorrer da década de 1990, ocorreu a expansão das escolas em diferentes níveis de ensino, o que significou uma mudança no perfil dos estudantes, que se tornou mais heterogêneo, pois crianças e jovens das classes populares, que antes não tinham acesso (ou eram expulsos das escolas), passaram a ser inseridos no ambiente escolar. Esta inserção dos jovens no processo de escolarização ainda não foi concluída no Brasil, apesar da obrigatoriedade do Ensino Médio, instituído através da lei 12.061/2009 (BRASIL, 2009). Esta mudança no perfil dos estudantes significou novas demandas e novos desafios para os que estão envolvidos nos processos educacionais nas escolas.

\footnotetext{
${ }^{2}$ As relações que estabelecemos com o contexto educacional serão feitas a partir dos dados no Brasil, uma vez que não conhecemos em profundidade a realidade dos jovens e da Educação nos outros países da pesquisa.
} 
Figura 1 - Como são os jovens de nosso país? Marque apenas uma alternativa, a que você considerar mais importante (em porcentagens)

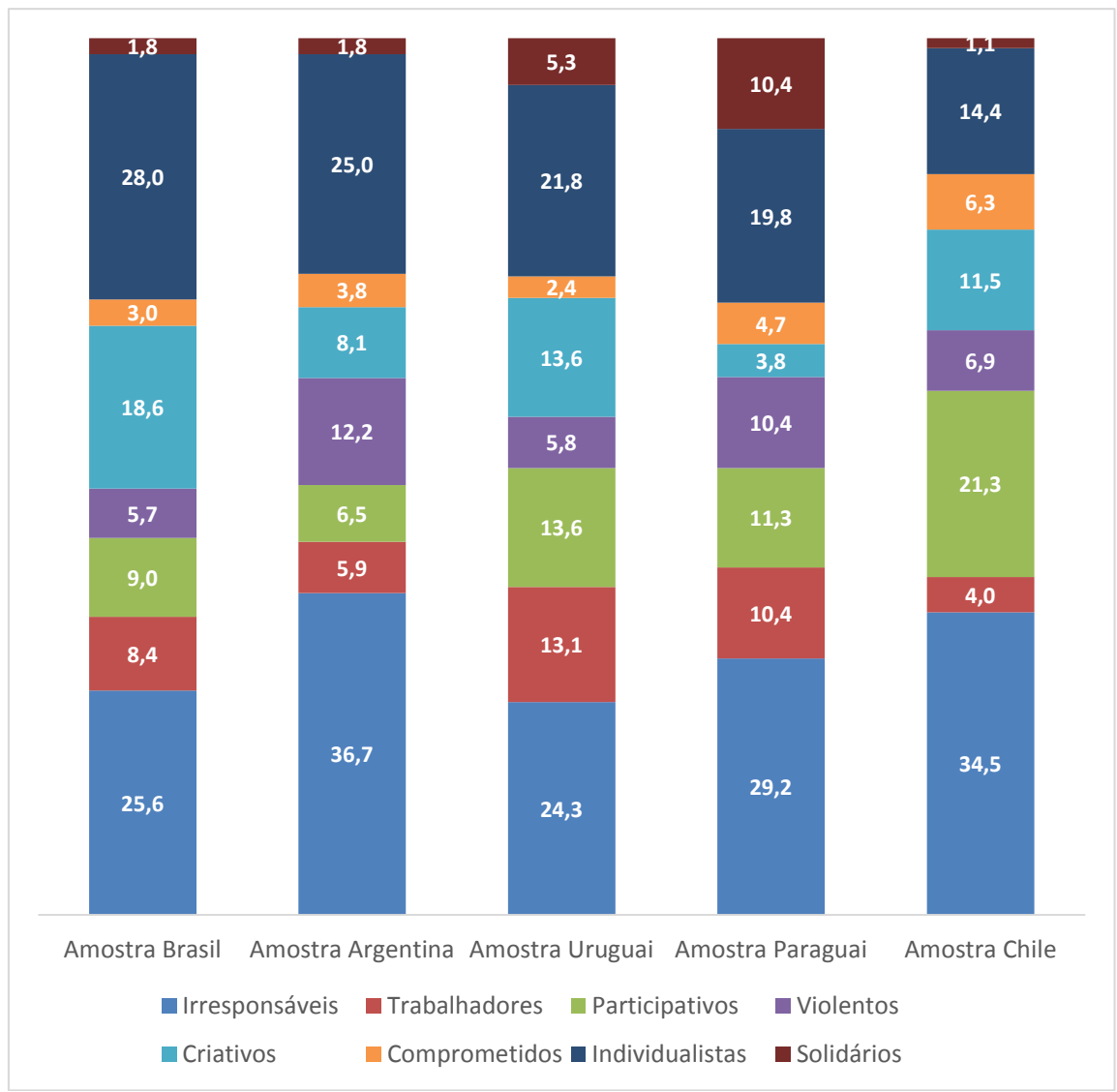

Fonte: Dados do projeto Jovens e a História. Questão ํo38 (2013). Disponível em: <http://proyectozorzal.org>. Acesso em: 22 jul. 2017.

A partir de duas questões respondidas pelos estudantes, a questão $\mathrm{n}^{\circ} 38$ - Como são os jovens de nosso país? Marque apenas uma alternativa, a que você considerar mais importante ${ }^{3}$ - e a questão $\mathrm{n}^{0} 42$ - Marque apenas uma alternativa, a que você considerar mais importante: em sua opinião, a juventude deve: ${ }^{4}$ - é possível entender como os jovens se auto identificam e qual deve ser sua atuação na sociedade atual nos diferentes países pesquisados. Em relação a auto representação dos jovens, constata-se que estes se identificam

\footnotetext{
${ }^{3}$ Para o espanhol, a pergunta foi vertida da seguinte forma: ¿Cómo es la gente joven de nuestro país? ${ }^{4}$ Para o espanhol, a pergunta foi vertida da seguinte forma: ¿En tu opinión, la juventud debe...?
} 
de modo negativo. Irresponsáveis e individualistas foram os itens mais votados em todos os países analisados. Criativos, violentos e participativos alternam-se em $3^{\circ}$ lugar, em diferentes países. No Brasil, a característica que obteve maior percentual foi o individualismo, com $28 \%$; seguido de irresponsáveis, com $25,6 \%$; e de criativos, com $18,6 \%$. Já entre os argentinos, chama a atenção o alto índice dos que afirmam que os jovens são irresponsáveis, o maior entre os países, com $36,7 \%$. Se somarmos este número com os $12,2 \%$ dados para violentos, e os $25 \%$ para individualistas, teremos um índice de 73,9\% de entrevistados que definem os jovens por seus defeitos. Os dados dos outros países não são tão dramáticos como, por exemplo, no Brasil, onde 59,3\% dos jovens se identificam negativamente, mas chama a atenção o fato de, em todos os países os entrevistados, terem se auto identificado de forma negativa.

Esta representação negativa da juventude, pelos próprios estudantes pesquisados e que são jovens, pode ser entendida de melhor forma se refletirmos à luz das representações sobre os jovens e a juventude que se difunde nos meios de comunicação. Estas representações estão assinaladas em pesquisas desenvolvidas, principalmente pelos sociólogos, no decorrer do século XX.

A juventude - como categoria social - surgiu com força no pós-guerra nos EUA, e muda a forma como este período da vida passa a ser percebido, tanto pelos adultos como pelos próprios jovens ${ }^{5}$. Na década de 1950, a juventude passou a ser vista como um período difícil, de questionamento e contestação. Isto é bastante veiculado por meio do cinema como, por exemplo, no filme Juventude Transviada, de 1955. Naquele momento, a rebeldia passou a ser vista como um estado pelo qual todos os jovens passariam, e não mais só os que integrariam as chamadas classes perigosas. A rebeldia deixou de ser demonizada, como restrita às classes perigosas, e passou a ser vista como normal, até mesmo como fonte de inovação e revigoramento social, desde que devidamente controlada através da recondução, após um tempo, destes rebeldes, aos padrões de normalidade estabelecidos socialmente.

\footnotetext{
${ }^{5}$ Sobre isto, ver os capítulos 29 e 30 de SAVAGE, Jon. A criação da Juventude: como o conceito de teenage revolucionou o século XX. Rio de Janeiro: Rocco, 2009.
} 
Já na década de 1960 e de 1970, os movimentos juvenis proliferaram e se ampliaram. Os jovens que participavam destes movimentos questionavam as organizações políticas, sociais, culturais e a moralidade das sociedades ocidentais. Eles se recusavam a se enquadrar. No Brasil, uma parcela dos jovens se envolveu nos movimentos contrários à ditadura civil-militar, e participou de movimentos culturais que questionavam os padrões culturais e morais. Segundo Helena Abramo (2007, p. 82), os "jovens apareciam como uma fonte de energia utópica do que propriamente pessoas capazes de levar a cabo efetivamente tal transformação". Salienta-se que esta imagem positiva dos jovens, dos anos 60 e 70 (idealistas, rebeldes, inovadores, utópicos), vai se construir, posteriormente, na década de 1980, quando os jovens serão vistos como apáticos, desinteressados e desmobilizados. Um exemplo desta representação sobre os jovens brasileiros dos anos 80 pode ser encontrado na música Terra de Gigantes, interpretada pela banda Engenheiros do Hawaii e composta por Humberto Gessinger, em 1987.

Já na década de 1990, os jovens passaram a se envolver com ações individuais e coletivas, ações fragmentadas, violentas, de desvio e desregramento. Os jovens passaram a ser vistos como vítimas, bem como promotores da dissolução social. A proclamação do ano de 1985, como Ano Mundial da Juventude pela ONU, e a promulgação do Estatuto da Criança e do Adolescente em 1990 (BRASIL, 1990) fez com que a questão da juventude se tornasse um tema de discussão pelo estado brasileiro, que iniciou uma série de políticas públicas voltadas para esta parcela da população brasileira que, anteriormente, somente era atendida a partir de sua inserção no espaço escolar (ABRAMO, 2007, KEHL, 2004, ABRAMO, 2008, PERALVA, 2007, DAYRELL 2007).

A imagem dos jovens na atualidade, como irresponsáveis, individualistas, desinteressados e apáticos é recorrente, também entre os/as professores/as, que reproduzem, de certo modo, uma representação repetida reiteradamente pelos meios de comunicação, principalmente a partir da década de 1990, quando a juventude passou a ser mais do que uma fase da vida, mas um signo possível de ser alcançado através do consumo. Um signo que passou a ser considerado o padrão cultural a ser atingido por 
todos, e que é marcado pelo individualismo, pelo efêmero, pelas relações descompromissadas, pela despreocupação com o futuro.

Enquanto a questão $\mathrm{n}^{0} 38$ queria saber como era, na opinião dos entrevistados, a juventude em seu país, a questão $\mathrm{n}^{0} 42$ - Em sua opinião, a juventude deve... - procura mapear qual a opinião dos estudantes sobre como deve ser a juventude e quais devem ser suas preocupações. As opções de respostas contemplam o compromisso com o social (lutar por suas ideias/ ideais e assumir responsabilidades trabalhando), a realização pessoal (formarse para o futuro e definir objetivos de vida para si) e uma opção hedonista (divertir-se e curtir a vida).

Figura 2 - Em sua opinião a juventude deve... (em porcentagens)

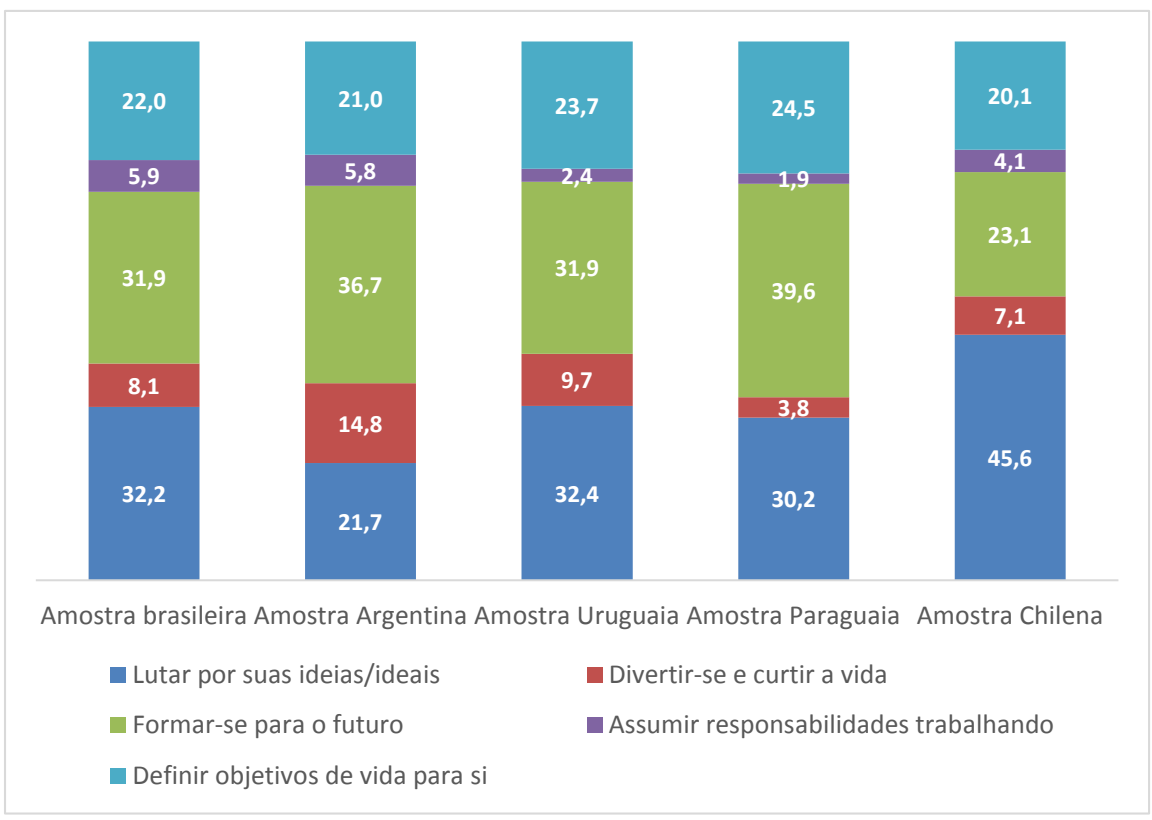

Fonte: Dados do projeto Jovens e a História. Questão n 42 (2013). Disponível em: <http://proyectozorzal.org>. Acesso em: 22 jul. 2017.

As respostas, no geral, mostram que os estudantes se dividiram entre as demandas pessoais, de se preparar para o futuro, e uma preocupação com o coletivo, de lutar por suas ideias/ideais. No entanto, aos analisarmos as respostas por países, identifica-se que, entre os brasileiros e uruguaios, estes dois itens obtiveram resultados muito próximos, o que mostra que os 
estudantes estão divididos entre as preocupações com o coletivo e com as demandas individuais. Já entre os argentinos e os paraguaios, a preocupação com o futuro individual foi predominante. O que chama a atenção é o resultado entre os chilenos, no qual $45 \%$ dos respondentes assinalaram que a luta por suas ideias/ideais é o aspecto que deve ser a prioridade da juventude. O que se salienta é a diferença entre a juventude que se apresenta nessas respostas e a imagem extremamente negativa sobre os jovens, indicada nos resultados da questão $\mathrm{n}^{\circ} 38$. Os resultados mostram que, o que se espera da juventude, é uma postura de responsabilidade com o futuro individual e mesmo com o coletivo, com uma baixa porcentagem (em torno de 5\%) dos entrevistados assinalando o item $42 \mathrm{~b}$, divertir-se e passar bem. Isto contradiz a imagem negativa sobre os jovens, que aparece nos resultados gerais da questão $\mathrm{n}^{\circ} 38$, quando a maioria assinalou, como característica predominante da juventude, a irresponsabilidade. Ao comparar as respostas das questões $n^{\circ} 38$ e $n^{\circ} 42$, pode-se inferir que os jovens incorporaram o discurso que circula, principalmente na mídia e entre os professores, de que eles são os responsáveis pelo futuro, mas que, no presente, eles são irresponsáveis. Os jovens são alvo de confiança (no futuro) por parte dos adultos, mas são alvo de desconfiança e medo (no presente). Este discurso maniqueísta é tão enraizado no senso comum que, mesmo os jovens, alvo deles, o reproduzem.

\section{OS JOVENS E O TEMPO PRESENTE, PASSADO E FUTURO}

Quando a um jovem é perguntado sobre a história ou sobre o passado de seu país, a orientação para o futuro é tão preponderante quando perguntado sobre o futuro, observando-se, claro, a relação mediada e inter-relacionada entre passado, futuro e presente. Como já informado, para este capítulo foram recortadas 9 questões específicas, com o objetivo de analisar a consciência histórica e a formação de sentido histórico entre os jovens estudantes. A pergunta $\mathrm{n}^{\circ} 2$ do questionário aplicado aos estudantes queria saber - dentre três alternativas apresentadas: a) Conhecer o passado; b) Compreender o presente; c) Buscar orientação para o futuro - qual seria a mais importante como objetivo ao se estudar a História. Os 
estudantes precisaram escolher, para cada uma delas, as seguintes variações: muito pouca; pouca; alguma; importante, muito importante, como se pode observar na tabela abaixo.

Tabela 1 - Em sua opinião, qual a importância de cada um dos objetivos ao se estudar a História: (em porcentagens)

\begin{tabular}{|c|c|c|c|c|}
\hline & & $\begin{array}{l}\text { Conhecer } \\
\text { o passado }\end{array}$ & $\begin{array}{l}\text { Compreender } \\
\text { o presente }\end{array}$ & $\begin{array}{l}\text { Buscar } \\
\text { orientação } \\
\text { para o futuro }\end{array}$ \\
\hline \multirow{5}{*}{$\begin{array}{l}\text { Amostra } \\
\text { Brasil }\end{array}$} & Muito pouca importância & 5,6 & 5,0 & 6,1 \\
\hline & Pouca importância & 3,0 & 5,2 & 8,5 \\
\hline & Alguma importância & 11,8 & 15,1 & 17,6 \\
\hline & Importante & 46,1 & 41,0 & 33,8 \\
\hline & Muito importante & 33,5 & 33,8 & 33,9 \\
\hline \multirow{5}{*}{$\begin{array}{l}\text { Amostra } \\
\text { Argentina }\end{array}$} & Muito pouca importância & 2,7 & 1,6 & 6,6 \\
\hline & Pouca importância & 6,2 & 7,3 & 15,9 \\
\hline & Alguma importância & 17,6 & 19,1 & 19,0 \\
\hline & Importante & 48,4 & 41,9 & 26,7 \\
\hline & Muito importante & 25,0 & 30,2 & 31,8 \\
\hline \multirow{5}{*}{$\begin{array}{l}\text { Amostra } \\
\text { Uruguai }\end{array}$} & Muito pouca importância & 1,4 & 0,9 & 6,0 \\
\hline & Pouca importância & 0,9 & 5,0 & 14,3 \\
\hline & Alguma importância & 16,5 & 15,8 & 26,3 \\
\hline & Importante & 49,5 & 39,6 & 30,4 \\
\hline & Muito importante & 31,7 & 38,7 & 23,0 \\
\hline \multirow{5}{*}{$\begin{array}{l}\text { Amostra } \\
\text { Paraguai }\end{array}$} & Muito pouca importância & 4,2 & 1,7 & 2,6 \\
\hline & Pouca importância & 3,4 & 4,3 & 3,4 \\
\hline & Alguma importância & 8,5 & 22,6 & 17,1 \\
\hline & Importante & 51,7 & 41,7 & 26,5 \\
\hline & Muito importante & 32,2 & 29,6 & 50,4 \\
\hline \multirow{5}{*}{$\begin{array}{l}\text { Amostra } \\
\text { Chile }\end{array}$} & Muito pouca importância & 1,9 & 1,2 & 1,8 \\
\hline & Pouca importância & 1,9 & 1,8 & 7,1 \\
\hline & Alguma importância & 6,3 & 13,5 & 17,8 \\
\hline & Importante & 43,4 & 32,2 & 36,1 \\
\hline & Muito importante & 46,5 & 51,5 & 37,3 \\
\hline
\end{tabular}

Fonte: Dados do projeto Jovens e a História. Questão no 2 (2013). Elaboração das autoras. 
Como era previsível, a maior parte das respostas dos jovens reportouse à importância do passado. Quando se considera o conjunto de todas as amostras, $78 \%$ deles responderam que o estudo da História é importante ou muito importante para conhecer o passado. O que não era tão previsível foi $75 \%$ dos jovens consideraram que a História é importante ou muito importante, também, para compreender o presente, e que $65 \%$ opinaram que é importante para buscar orientação para o futuro. Nos diferentes países, a tendência se assemelha, ainda que com variações de intensidade. Neste caso, para além de ponderar que os jovens opinaram considerando a resposta que eles achavam que os pesquisadores esperavam, também se pode cogitar que essas perspectivas (presente e futuro) têm sido enfatizadas nas aulas de História desses países.

No Brasil, apesar dos livros didáticos ${ }^{6}$ trazerem os conteúdos históricos majoritariamente organizados a partir da lógica cronológica linear (MIRANDA; LUCA, 2004), a presença de outras concepções de História, como a história-problema da Escola dos Annales, tem ampliado a concepção sobre o papel da História escolar. Este questionamento ocorreu a partir do retorno da História como disciplina autônoma nos anos de 1980, com a reabertura política, e que vai estabelecer, como função do ensino de História, a formação para a cidadania, o que se fortalece com a publicação dos Parâmetros Curriculares Nacionais (PCN) em 1996, que definiu, como fundamental para a aprendizagem histórica, a discussão de conceitos como tempo, fato histórico, sujeito histórico, e o estabelecimento de temas transversais, entre os quais, cidadania.

Além disso, a aprovação, em 2003, da lei 10.639 (que estabeleceu a obrigatoriedade do ensino de História e cultura africanas e afro-brasileiras e uma educação das relações étnico-raciais na escola, BRASIL, 2003), modificada pela Lei 11.645/2008 (que incluiu a obrigatoriedade do ensino de História indígena, BRASIL, 2008), trouxe para o debate questões como a pluralidade cultural, as discussões sobre as relações étnico-raciais e o questionamento da história eurocêntrica. Na Argentina e no Chile, a discussão pública sobre o período dos governos militares é muito distinta do

\footnotetext{
${ }^{6}$ A maioria dos estudantes brasileiros tem acesso a eles através do Programa Nacional do Livro Didático (PNLD), do Ministério da Educação (MEC).
} 
que ocorre no Brasil. No caso argentino, os debates públicos, denúncias e questionamentos em relação ao governo militar começaram após a derrota na Guerra das Malvinas, em 1982. No campo educacional, dois eventos da última ditadura militar tornaram-se efemérides escolares, momentos para refletir sobre um passado doloroso: o 24 de março (aniversário do golpe) e o 16 de setembro (aniversário da Noite dos Lápis) ${ }^{7}$. Além disso, na década de 1980 começaram a ser julgados os abusos cometidos pelo Estado argentino através dos órgãos de repressão, o que fez com que o tema dos desaparecidos políticos fosse amplamente divulgado pela imprensa (LORENZ, 2007).

As questões 19 e 20 incidem diretamente sobre estas perspectivas, buscando indícios mais concretos sobre o ensino de História nas escolas e a formação de sentido histórico. A questão de $\mathrm{n}^{\circ} 19$ colocava em perspectiva o passado em relação ao presente - Que influência você acha que tiveram os seguintes fatores na mudança na vida das pessoas desde 1970 até hoje? ${ }^{8} \mathrm{E}$ outra colocava a perspectiva do futuro em relação ao presente, $\mathrm{n}^{\circ} 20$ - Que influência você acha que terão os seguintes fatores na mudança da vida das pessoas de agora até 2050 ? $^{9}$ Ambas vinham acompanhadas de 15 alternativas, desde invenções técnicas e inovações (19a), desenvolvimento da ciência e do conhecimento (19f), passando por guerras e conflitos (19g), até migrações (191) e cientistas e engenheiros (19o). As respostas nos cinco países apresentam, com alguns matizes, a mesma tendência, e os resultados não diferem, em grande medida, entre uma e outra questão.

\footnotetext{
${ }^{7}$ A Noite do Lápis refere-se ao sequestro de 10 estudantes secundaristas da cidade de La Plata, iniciado na noite de 16 de setembro de 1976, durante o governo militar de Jorge Rafael Videla. As vítimas eram, em sua maioria, vinculadas à União Estudantil Secundária. Os estudantes sequestrados, exceto uma, tinham se mobilizado no ano anterior para obterem passagem estudantil com tarifa preferencial, o que foi cancelado após o golpe de março de 1976. Durante o cativeiro, os jovens foram torturados, o que levou a maioria deles a óbito. O fato ficou conhecido quando um dos sobreviventes, Pablo Díaz, fez seu depoimento no Juízo às Juntas em 1985, e foi amplamente divulgado na imprensa, através de um livro e do filme La noche de los lapices, que estreou em 1986.

${ }^{8}$ Para o espanhol, a pergunta foi vertida da seguinte forma: ¿Qué influencia encontrás que tuvieron los siguientes factores en el cambio de la vida de las personas en la historia más reciente?

${ }^{9}$ Para o espanhol, a pergunta teve a seguinte configuração: 20. ¿Qué influencia pensás que tendrán los siguientes factores en el cambio de la vida de las personas en los próximos 40 años?
} 
Figura 3 - Que influência você acha que terão os seguintes fatores na mudança da vida das pessoas de agora até 2050? (médias)*

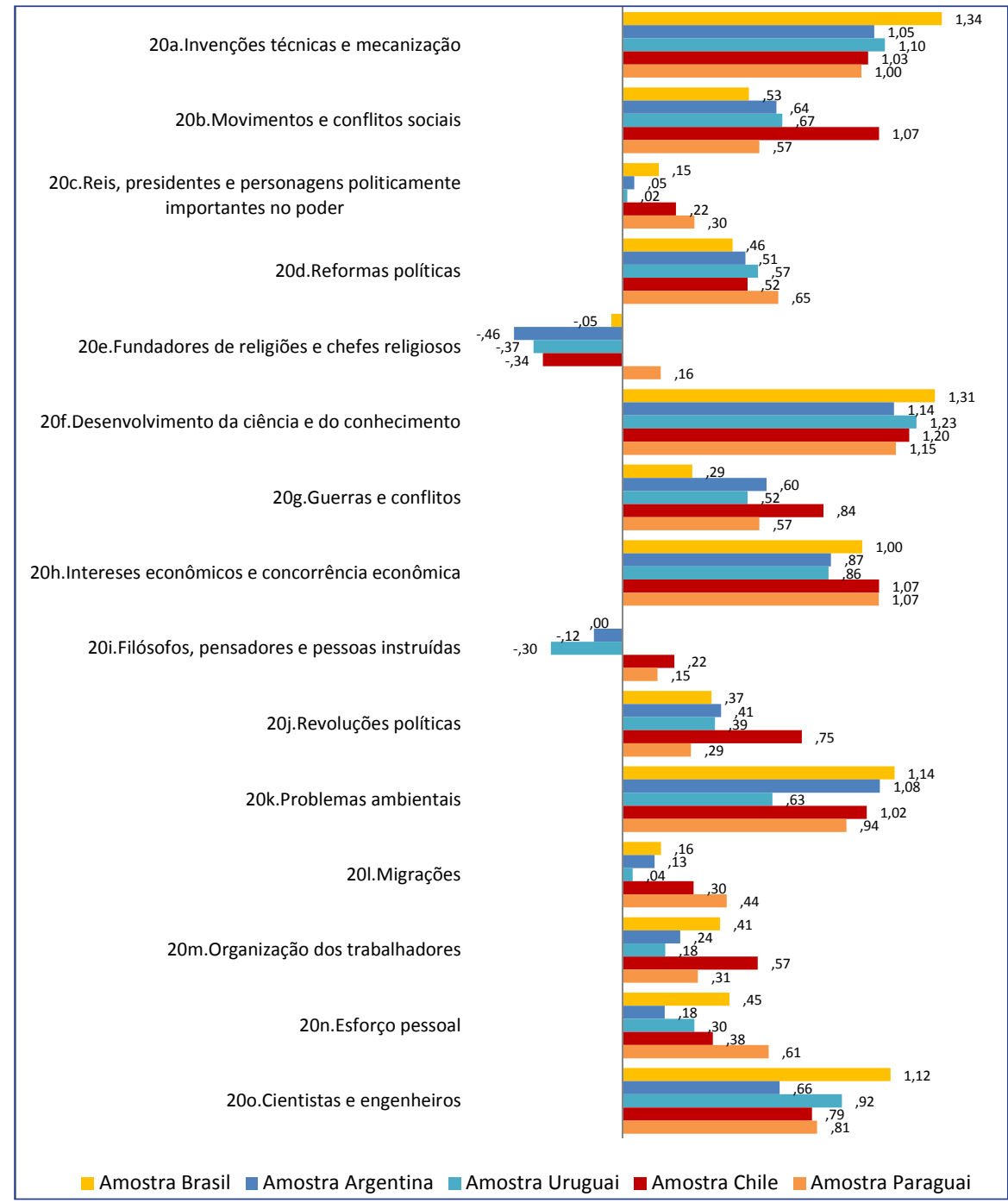

Fonte: Dados do projeto Jovens e a História. Questão no 38 (2013). Disponível em: <http://proyectozorzal.org>. Acesso em: 22 jul. 2017.

* As médias indicadas no gráfico foram compostas a partir da transformação das respostas, da escala Likert para uma escala numérica (muito pouca $=-2$; pouca $=-1$; média $=0$; grande $=1$; muito grande $=2$ ), sobre a qual se calculou a média aritmética das repostas em cada item.

As respostas informam que os estudantes privilegiam, de modo significativo, a contribuição da ciência e do conhecimento, bem como as inovações tecnológicas como as variáveis capazes de explicar o mundo 
atual. As opções sobre as invenções técnicas e a mecanização (20a), e o desenvolvimento da ciência e do conhecimento (20f) destacam-se em ambas as respostas. Contudo, no caso da questão $n^{0} 20$, pode-se afirmar que o resultado é mais incisivo, já que a alternativa de importância muito grande é mais selecionada do que na questão de $\mathrm{n}^{0} 19$.

As respostas indicam algumas hipóteses iniciais. Tal percepção poderia estar mais ancorada em ideias aprendidas fora da escola do que nela. Isto porque, muito embora nos últimos tempos, diferentes países tenham incorporado perspectivas mais variadas ao estudo do passado, ainda se observa certo centramento nos processos políticos e nos fatos históricos de um passado que não é recente. Deste modo, poderia ser lícito supor que a percepção da importância da ciência, da tecnologia e do conhecimento seja influenciada mais pelo que se aprende sobre mudanças e processos fora da sala de aula, por meio, principalmente, dos meios de comunicação de massa, do que na escola. Um aspecto que pode ser atribuído às mudanças no ensino de História, ainda que se considere, também, a influência extraescolar, é a importância relativamente alta atribuída aos movimentos e conflitos sociais (19b) para o presente. Os dados favorecem a hipótese de que a escola é apenas mais um fator - e não é o mais importante - nas representações do passado, que predominam nas percepções dos jovens.

Ao mesmo tempo, percebe-se a importância dada pelos jovens às questões tecnológicas nas transformações pelas quais passamos/passaremos. Constata-se, a partir das respostas a questão $\mathrm{n}^{\circ} 19$, a presença, também, das questões políticas e sociais nas transformações recentes. Os entrevistados consideraram como grande a influência, na História recente, a atuação dos presidentes e personagens politicamente importantes (19c), os movimentos e conflitos sociais (19b), as reformas políticas (19d), os interesses econômicos e competência econômica $(19 \mathrm{~h})$, bem como as questões referentes à organização dos trabalhadores $(19 \mathrm{~m})$ e as revoluções políticas (19j). Estes resultados se devem ao enfoque da História aprendida na escola? História que, apesar das mudanças nas últimas décadas, ainda mantém um grande espaço para as questões políticas e incorporou as discussões econômicas e os novos personagens, como os trabalhadores e os movimentos sociais sem, no entanto, deixar totalmente de lado uma História personalista. 
A novidade apresentada na questão de $\mathrm{n}^{0} 20 \mathrm{diz}$ respeito aos problemas ambientais, que passaram a ser considerados, pelos jovens, como um fator de impacto muito grande nas transformações nas próximas décadas, ficando lado a lado com os outros itens mais votados, que foram invenções técnicas e mecanização, e desenvolvimento da ciência e do conhecimento. Chama a atenção esta mudança, uma vez que, na questão $n^{\circ} 19$, que perguntava qual a influência dos mesmos fatores nas transformações ocorridas nas últimas décadas, o item problemas ambientais aparece como um fator de média e muito grande importância para a maioria dos respondentes da pesquisa, totalizando pouco mais de $30 \%$ das respostas em cada item.

A questão 26 seguiu investindo na busca de indícios sobre a percepção do tempo pelos jovens:

Figura 4 - Muitas vezes se olha a história como uma linha do tempo. Qual das seguintes linhas você pensa que descreve melhor o desenvolvimento da história? (em porcentagens)

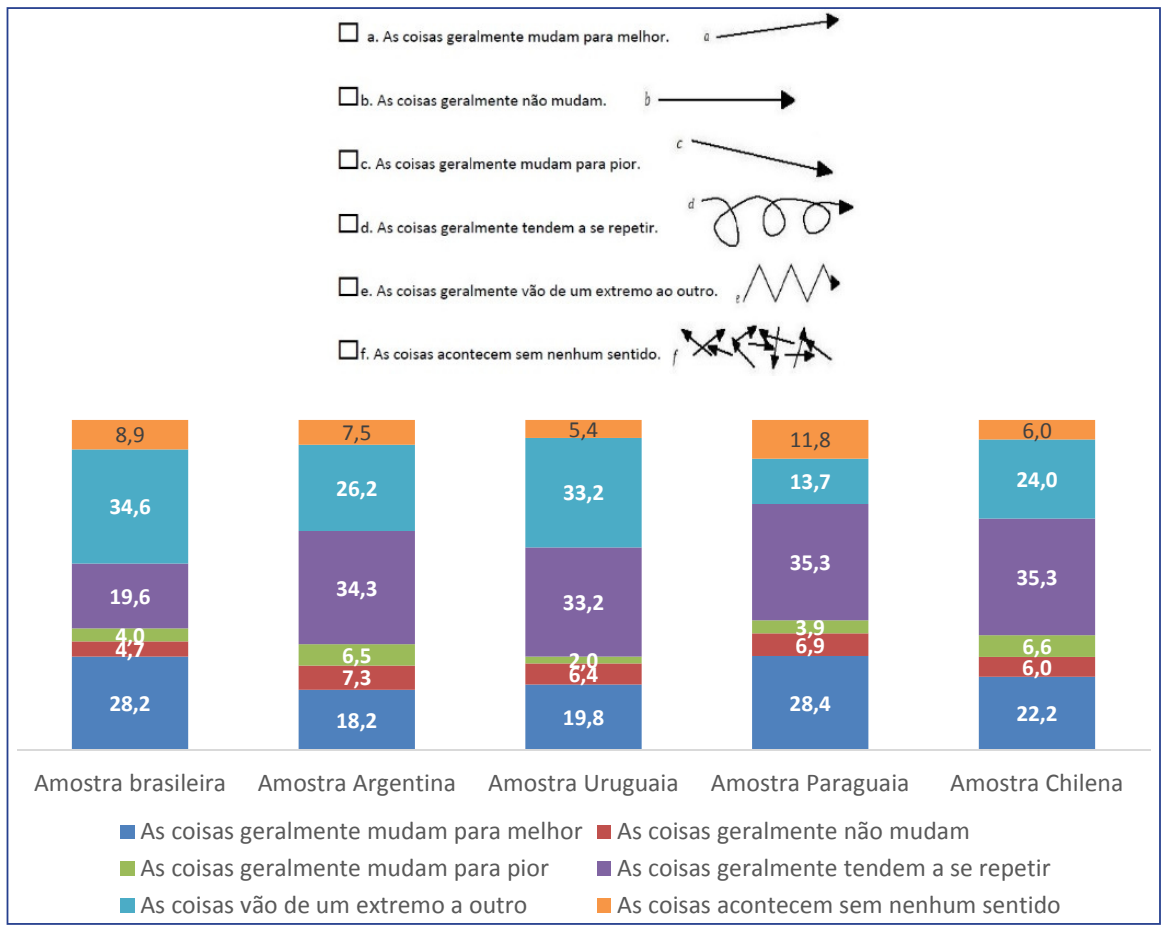

Fonte: Dados do projeto Jovens e a História. Questão № 26 (2013). Disponível em: <http://proyectozorzal.org>. Acesso em: 22 jul. 2017. 
A análise do total dos dados mostra que cerca de um quarto dos jovens consideram que as coisas mudam tendendo a melhorar no futuro, o que evidencia a longa duração da ideia de progresso, que ganhou força com o pensamento moderno e teve sua maior vigência entre 1750 e 1900. Essa visão otimista do futuro é mais forte entre os jovens do Paraguai e do Brasil, e mais fraca nos jovens da Argentina. Dentro das escolhas majoritárias encontra-se, também, as coisas geralmente tendem a se repetir, e no caso do Brasil, é uma alternativa que teve apenas 19,6\%, enquanto a média, nos demais países, foi em torno de $35 \%$. As alternativas foram minoritárias, mas as coisas geralmente não mudam parece mostrar uma visão fatalista, na qual ganhadores e perdedores da história estão predeterminados, e as coisas geralmente mudam para pior poderia ser considerada uma visão ainda mais negativa e extrema, que ressalta a incerteza do futuro. Nesta questão, chama a atenção a diferença entre o Brasil e os outros países, principalmente a Argentina, em relação às seguintes respostas: as coisas geralmente mudam para melhor e as coisas geralmente tendem a se repetir. Enquanto os jovens brasileiros podem ser considerados otimistas, uma vez que $28,2 \%$, contra $18,2 \%$ entre os argentinos, têm uma percepção de avanço e melhoria do presente em relação com o passado. No item as coisas geralmente tendem a se repetir ocorre o inverso: $34,3 \%$ dos argentinos versus $19,6 \%$ dos brasileiros. A ideia de repetição, o que pode remeter tanto a uma noção de tempo cíclico, como a noção de que a sociedade não aprende com suas experiências, é muito mais presente entre os jovens do país vizinho do que entre os jovens brasileiros. Este fator se complementa, no caso dos jovens brasileiros, ao identificarmos que $34,6 \%$ responderam que as coisas geralmente vão de um extremo a outro, o que remete a uma noção de instabilidade muito grande entre os nossos jovens. Nesta questão, o item $\mathrm{f}$, as coisas ocorrem sem nenhum sentido, não foi marcada pelos respondentes da pesquisa, o que denota que, para os jovens, as transformações temporais, seja de que modo se apresentam, possuem um sentido.

As questões 27, 28 e 29 buscaram respostas que confrontam perspectivas do passado e do futuro em relação ao presente dos jovens. A questão $\mathrm{n}^{\circ} 27$ quis saber: Como você pensa que era a vida do seu país há 40 anos? A 
de $\mathrm{n}^{\circ} 28$ - Como você acha que será a vida do seu país daqui a 40 anos? E a de $\mathrm{n}^{\circ} 29$ - Como você acha que será a sua vida daqui a 40 anos? As questões 27 e 28 repetem as 7 alternativas que vão desde Pacífica a Agitada por conflitos políticos, bem como as opções para cada uma delas que vão de muito difícil a muito provável. Esse conjunto de perguntas seguiu querendo conhecer as representações dos jovens sobre o passado recente e as perspectivas de futuro em relação aos seus países e a sua própria vida.

Figura 5 - Como você pensa que era a vida do seu país há 40 anos?

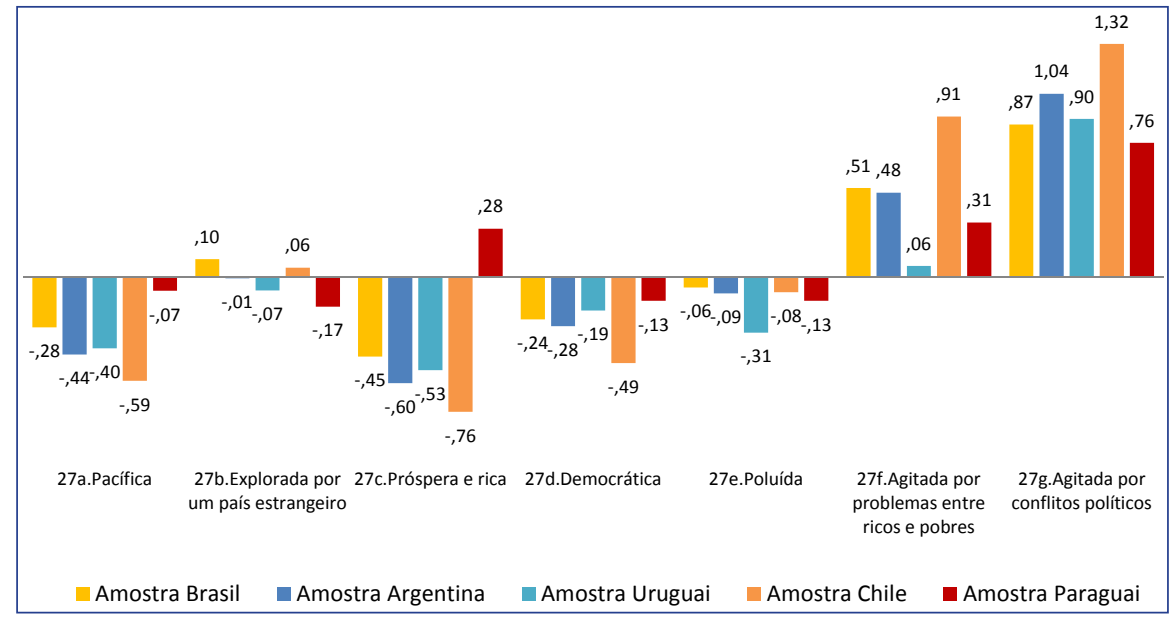

Fonte: Dados do projeto Jovens e a História. Questão no 27 (2013). Disponível em: <http://proyectozorzal.org>. Acesso em: 22 jul. 2017.

* As médias indicadas no gráfico foram compostas a partir da transformação das respostas, da escala Likert para uma escala numérica (muito dificilmente $=-2$; dificilmente $=-1$; talvez $=0$; provavelmente $=1$; muito provavelmente $=2$ ), sobre a qual se calculou a média aritmética das repostas em cada item.

Apesar da maior parte dos jovens ter assinalado o item talvez, o que remete provavelmente a uma insegurança e/ou desconhecimento sobre o passado do seu país em um período mais recente, podemos identificar a presença de algumas certezas: a constatação entre os jovens de que seus países não eram ricos e prósperos, bem como não eram pacíficos e/ou democráticos, que eram agitados por conflitos políticos e, em menor grau, pelas diferenças sociais. Com exceção da Argentina, conteúdos históricos mais recentes sobre a história nacional são pouco trabalhados nas aulas de História. No caso brasileiro é frequente, entre os professores de História, 
a constatação de que os conteúdos são muitos e que raramente conseguem trabalhar de modo mais aprofundado temas como a ditadura militar (19641985) e o processo de redemocratização.

Figura 6 - Como você acha que será a SUA vida daqui a 40 anos?

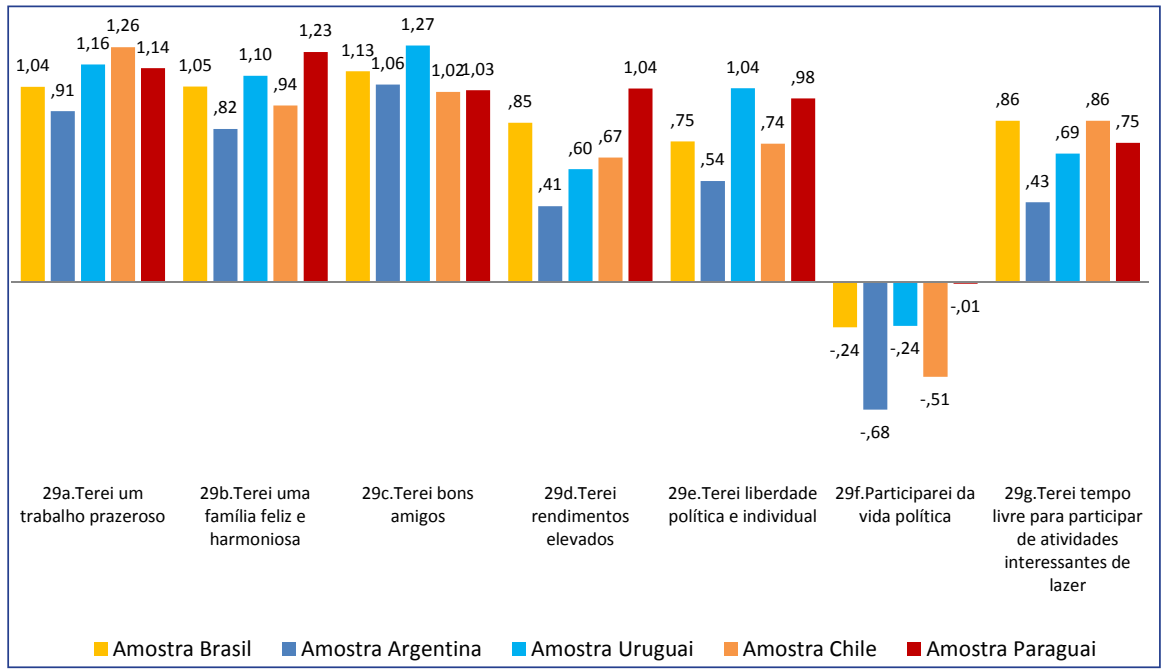

Fonte: Dados do projeto Jovens e a História. Questão № 29 (2013). Disponível em: <http://proyectozorzal.org>. Acesso em: 22 jul. 2017.

* As médias indicadas no gráfico foram compostas a partir da transformação das respostas, da escala Likert para uma escala numérica (muito dificilmente $=-2$; dificilmente $=-1$; talvez $=0$; provavelmente $=1$; muito provavelmente $=2$ ), sobre a qual se calculou a média aritmética das repostas em cada item.

Já na questão 29, ao falar do futuro, de como pensa que será sua vida nos próximos 40 anos, constata-se um grande otimismo em relação às conquistas pessoais, principalmente aquelas relacionadas às sociabilidades, como a construção de uma família e o estabelecimento de boas relações de amizade, e a confiança em relação à conquista de um trabalho que seja prazeroso e que lhe permita ganhos financeiros suficientes para poder gozar de tempo livre. A ênfase em um futuro que lhe permita ter prazer no trabalho, bem como ter tempo para o ócio, a recreação e as atividades interessantes é uma resposta (ou um desejo) em relação ao tempo presente, no qual os jovens, como estudantes, são obrigados a se dedicarem a atividades que não foram definidas por eles, e das quais muitos não gostam? Nas respostas a esta questão, identifica-se um grande otimismo, o que demonstra grande 
confiança dos jovens em si mesmos enquanto indivíduos, o que não se constata quando das respostas à questão 28 , quando é perguntado Como você acha que será a vida do seu país daqui a 40 anos? Nas respostas aos itens desta questão, identificou-se a continuidade do pessimismo em relação ao futuro coletivo. Esta contradição entre pessimismo em relação ao futuro do país e forte otimismo em relação a seu futuro pessoal talvez possa ser entendida a partir da percepção de um hiato entre o coletivo, o público e o individual, o privado. Para a maior parte dos jovens, a participação na vida política não é um horizonte de expectativa, ao mesmo tempo em que uma relativamente grande parte dos jovens respondeu talvez ao item 29e. Terá liberdade política e individual. Esta também é a conclusão a que chegam Miriam Abramovay, Mary Castro e Julio Waiselfisz na pesquisa Juventudes na Escola, Sentidos e Buscas: Por que frequentam? desenvolvida no ano de 2013 em 5 capitais e 5 municípios do interior nos estados do Rio de Janeiro, Bahia, Paraná, Mato Grosso e Pará com jovens entre 14 e 30 anos, na qual foram ouvidos jovens estudantes no Ensino Médio, EJA e Projovem Urbano ${ }^{10}$. A pesquisa foi desenvolvida a partir "de questões propostas pelos pesquisadores em questionários, possibilitando análise extensiva, parte do survey, como apreender práticas discursivas, [...] e em grupos focais e debates coletivos" (ABRAMOVAY; CASTRO; WAISELFISZ, 2015, p. 20). Uma das conclusões é de que as expectativas apresentadas pelos jovens, em relação a seu futuro, não fogem ao senso comum, e se restringem à inclusão nas regras do sistema, o que significa a busca por estudos que os habilitem ao acesso a um trabalho bem remunerado e a outros desejos, como constituir família e ser feliz. Segundo os pesquisadores, "os discursos sugerem uma juventude que, mesmo crítica da escola, e até das oportunidades sociais, não ousa relacionar seu futuro a outro futuro, o da sociedade" (ABRAMOVAY; CASTRO; WAISELFISZ, 2015, p. 235).

\section{CONSIDERAÇÕES FINAIS}

Esta pesquisa com os jovens possibilita algumas reflexões acerca da relação que eles estabelecem com o passado e com o futuro. Algumas das

\footnotetext{
${ }^{10}$ Entre os jovens entrevistados, $69,9 \%$ têm entre 15 e 19 anos de idade, 55,3\% são mulheres e 44,7\% são homens, e 63,5\% identificaram-se como pardos ou pretos.
} 
questões analisadas mostram que os jovens são vistos pela sociedade e por eles mesmos de modo dúbio. Apesar de os jovens terem uma representação negativa de si mesmos, se considerando como irresponsáveis e individualistas, eles também consideram que é sua função não somente se prepararem para o futuro, através da formação, mas também participarem das demandas do presente através da defesa de seus ideais. Ou seja, no presente, suas perspectivas dividem-se entre o individualismo e a preocupação com as demandas sociais. Sobre o papel do ensino de História, eles consideraramno importante para conhecer o passado, também muito importante para compreender o presente e orientar-se para o futuro. O que se constata é a permanência da noção de progresso, o que leva os jovens a uma postura positiva em relação ao futuro, principalmente ao seu futuro pessoal. No que se refere ao futuro coletivo, os jovens têm uma perspectiva distinta, alguns são marcadamente negativos, como os argentinos; outros bem mais otimistas, como os brasileiros e paraguaios.

Nas últimas décadas e cada vez mais, os jovens interpretam passado e futuro sob um presente alargado, hipertrofiado, o que impõe desafios ao ensino de História nas escolas por alterar de modo significativo a consciência temporal. O historiador franco-polonês Krzysztof Pomian (2013) analisa essa mudança, destacando que o futuro não é mais orientado pelo passado distante. Não que o passado não exista; ao contrário, é onipresente. Mas esse passado, para toda uma geração de jovens, acaba sendo depósito de eventos exóticos, estranhos. Ele é interessante e atrativo como conteúdo de filmes, novelas, romances, mas não como orientação temporal para um futuro coletivo. Assim, o ensino de História só seria relevante se o futuro fosse significado no presente, pois o passado distante não faria mais sentido para os jovens.

A orientação temporal centrada no presente é o mais difícil de superar como desafio, pois vai além do entendimento do tempo como histórico, cobrindo aspectos filosóficos e de constituição e significação da existência. Como tempo histórico, o presente se constrói em contraposição ao passado, e o passado é sempre reconstruído no presente. A diferença entre um e outro está no contraste, que é, também, uma operação mental, intelectual, 
emocional e, ao mesmo tempo, puramente arbitrária e subjetiva. Isto porque presente e passado são intervalos de tempo com comprimentos variáveis, ou seja, são durações que variam segundo escalas próprias e irredutivelmente plurais (POMIAN, 2013). Depreende-se que qualquer alteração na percepção de um desses tempos implica imediatamente a alteração da significação do outro.

\section{REFERÊNCIAS}

ABRAMO, Helena Wendel. Condição juvenil no Brasil contemporâneo. In: ABRAMO, Helena Wendel; BRANCO, Pedro Paulo Martoni (orgs.). Retratos da juventude brasileira. São Paulo: Editora Fundação Perseu Abramo, 2008, . p. 37-72.

ABRAMO, Helena Wendel. Considerações sobre a tematização social da juventude no Brasil. In: Juventude e contemporaneidade. Brasília: UNESC, MEC, ANPEd, 2007, p. 73-90.

ABRAMOVAY, Miriam; CASTRO, Mary; WAISELFISZ, Julio (org.). Juventudes na escola, sentidos e buscas: por que frequentam? BrasíliaDF: Flacso-Brasil, OEI, MEC, 2015. Disponível em: <http://flacso.org. $\mathrm{br}$ /?publication=juventudes-na-escola-sentidos-e-buscas-por-quefrequentam>. Acesso em: 25 set. 2016.

BERGMANN, Klaus. A História na reflexão didática. Dossiê História em Quadro-Negro: escola, ensino e aprendizagem. Revista Brasileira de História. São Paulo: vol. 9, n. 19, set. de 1989/fev. de 1990, p.30-32.

BOURDIEU, Pierre. A “Juventude” é apenas uma palavra. In: BOURDIEU, Pierre. Questões de sociologia. Rio de Janeiro: Marco Zero, 1983, p. 112-121. BRASIL. Estatuto da Criança e do Adolescente. Lei no 8.069, de 13 de julho de 1990. Disponível em: http://www.planalto.gov.br/ccivil_03/leis/18069. htm. Acesso: 26 jun. 2018.

. Lei $n^{\circ} 10.639$, de 9 de janeiro de 2003. Disponível em: http://www. planalto.gov.br/ccivil_03/Leis/2003/L10.639.htm. Acesso: 26 jun. 2018. 
. Lei $n^{\circ} 11.645$, de 10 de março de 2008. Disponível em: http:// www.planalto.gov.br/ccivil_03/_ato2007-2010/2008/lei/111645.htm. Acesso: 26 jun. 2018.

. Lei $n^{\circ} 12.061$, de 27 de outubro de 2009. Disponível em: http:// www.planalto.gov.br/ccivil_03/_ato2007-2010/2009/lei/112061.htm. Acesso: 26 jun. 2018.

Estatuto da Juventude. Lei no 12.852, de 5 de agosto de 2013. Disponível em: http://www.planalto.gov.br/ccivil_03/_ato2011-2014/2013/ lei/112852.htm. Acesso: 26 jun. 2018.

CERRI, Luis Fernando. Tipos de geração de sentido histórico - um ensaio com dados quantitativos. In: SCHMIDT, Maria A.; BARCA, Isabel.; URBAN, Ana C.. (Org.). Passados possíveis: a educação histórica em debate. Ijuí: Ed. Unijuí, 2014, p. 179-194.

DAYRELL, Juarez. O jovem como sujeito social. In: Juventude e contemporaneidade. Brasília: UNESC, MEC, ANPEd, 2007, p. 155-176.

KEHL, Maria Rita. A juventude como sintoma da cultura. In: NOVAES, Regina; VANNUCHI, Paulo (orgs.) Juventude e sociedade: trabalho, educação e participação. São Paulo: Editora Fundação Perseu Abramo, 2004, p. 89-114. LORENZ, Federico Guillermo. O passado recente na Argentina: as difíceis relações entre transmissão, educação e memória. In: CARRETERO, Mario; ROSA, Alberto; GONZÁLEZ, Maria Fernanda (orgs.) Ensino da história e memória coletiva. Porto Alegre: Artmed, 2007, p. 229-242.

MARGULIS, Mario; URRESTI, Marcelo. La juventud es más que una palabra. In: Margulis, M. (org.). La juventud es más que una palabra. Buenos Aires, Biblos, 1996, p. 19-32.

MINAYO, Maria Cecília. S; SANCHES, Odécio. Quantitativo-Qualitativo: Oposição ou Complementaridade? Cadernos de Saúde Pública, Rio de Janeiro, v. 9, n. 3, p. 239-262, jul/set. 1993. Disponível em: <http://unisc.br/ portal/upload/com_arquivo/quantitavivo_qualitativo_oposicao_ou_ complementariedade.pdf $>$. Acesso em: 17 set. 2016. 
MIRANDA, Sonia Regina; LUCA, Tânia Regina de. O livro didático de história hoje: um panorama a partir do PNLD. Revista Brasileira de História. São Paulo, v. 24, n 48, 2004, p. 123-144.

PERALVA, Angelina T.. O jovem como modelo cultural. In: Juventude e contemporaneidade. Brasília: UNESC, MEC, ANPEd, 2007, p. 13- 27.

POMIAN, Krzysztof. Partir du Présent. Le Débat, Éditions Gallimard, n 175 p.79-92, mai/out. 2013. Disponível em: <http://www.le-debat. gallimard.fr/articles/2013-3-partir-du-present>. Acesso em: 14 agost. 2014. PROYECTO ZORZAL, [s.d.]. Disponível em: 〈http://proyectozorzal.org〉. Acesso em: 22 jul. 2016.

RICOEUR, Paul. A memória, a história, o esquecimento. Campinas/SP: Unicamp, 2007.

RÜSEN, Jörn. História viva. Teoria da História: formas e funções do conhecimento histórico. Tradução de Estevão de Rezende Martins. Brasília: UNB, 2007.

RÜSEN, Jörn. Como dar sentido ao passado: questões relevantes de meta-história. História da Historiografia, n.2, p. 163-209, março 2009. Disponível em: <https:/www.historiadahistoriografia.com.br/revista/ article/view/12/12>. Acesso: 20 set. 2016.

RÜSEN, Jörn. Cultura faz sentido. Orientações entre o ontem e o amanhã. Tradução de Nélio Schneider. Petrópolis/RJ: Vozes, 2014.

SAVAGE, Jon. A criação da juventude: como o conceito de teenage revolucionou o século XX. Rio de Janeiro: Rocco, 2009. 


\section{CONCEPÇÕES DE ENSINO E APRENDIZAGEM DE HISTÓRIA ENTRE JOVENS ESTUDANTES DE FLORIANÓPOLISISC}

Nucia Alexandra Silva de Oliveira

\section{CONSIDERAÇÕES INICIAIS}

Em livro já referenciado por diversas gerações de historiadores, Marc Bloch (2001) fala sobre a curiosa indagação de seu filho sobre a utilidade da História. Diante do questionamento infantil, o mestre coloca-se a pensar e apresenta uma densa e relevante análise sobre o ofício do historiador. Muitos de nós já estivemos neste mesmo lugar, diante das mesmas indagações - sejam elas feitas por crianças do círculo privado ou, ainda, por estudantes. Hoje, mais do que nunca, cabe colocar a questão: Para que serve a História? Ou ainda: Para que serve estudar História?

Vivemos tempos de incertezas quanto ao futuro desta disciplina e sobre o papel de professores junto a ela. Nossas falas, muitas vezes parecem vigiadas e vivem o absurdo da ameaça de criminalização! Mas já experimentamos tempos de muita turbulência e, se no passado eles foram superados, cabe, agora, grande empenho para que a atual situação de crise também seja vencida e que, assim, o ensino de História possa ser vivenciado de forma autônoma, propiciando os debates tão necessários a nossa profissão e à disciplina.

Foi pensando nas indagações de jovens estudantes quanto à necessidade de aprender História e nas tantas demandas que são colocadas aos professores que iniciamos a reflexão apresentada no presente artigo. Afinal, não existe possibilidade de estudar o ensino de História sem colocar, como protagonistas, estudantes e professores!

Para a análise aqui apresentada, optamos por problematizar os dados coletados com os questionários preenchidos por estudantes da cidade de Florianópolis/SC. Compreendemos que a análise da amostra local permitirá que sejam conhecidos elementos importantes para a reflexão sobre a percepção desses estudantes sobre a disciplina, e paralelo a isso, pode instrumentalizar, também, para a formação de professores. Ainda pode 
ajudar aos professores de História a pensar os objetivos de seus planejamentos e atividades.

Para dar conta de tal reflexão, serão analisadas as questões que, de algum modo, permitam conhecer a opinião desses jovens sobre o significado do ensino de História e dos seus objetivos, bem como sobre os processos que o envolvem. Além disso, também questões que tratam das temáticas e do desenvolvimento metodológico das aulas serão observadas para mapear as leituras que os estudantes fazem da dinâmica delas.

O objetivo do texto é, assim, analisar as experiências de aprendizado expressas nas respostas apresentadas pelos estudantes entrevistados em Florianópolis e, na medida do possível, compará-las aos demais dados obtidos com a pesquisa Jovens e a História. Resumindo, portanto, o que será lido, aqui, é um esforço no sentido de identificar como jovens estudantes compreendem a função do ensino de História e que leituras fazem desse processo. Tratando, ainda de, ao analisar as compreensões desses/ as jovens estudantes, conhecer nuances importantes da História como disciplina escolar.

Em relação à pesquisa, cabe abrir espaço para ressaltar que a realização de um mapeamento tão abrangente e ambicioso, em termos geográficos e em seus objetivos é, sem dúvida, um desafio. Mas o esforço em captar e sistematizar os dados é plenamente justificado pela riqueza e diversidade de observações que podem ser feitas com as respostas dadas por estudantes e professores de História. As aproximações com as reflexões propostas da Didática da História são estreitas e, neste sentido, a pesquisa é um compromisso com o Ensino de História e as formas de articulação/vivência do aprendizado histórico na Educação Básica, e também na vida dos estudantes.

Pessoalmente destacamos que, em princípio, a possibilidade de lidar com gráficos e escalas nos pareceu bastante difícil. Professores de História não são, em sua maioria, muito íntimos de números e gráficos, mas, aos poucos, as tabelas foram se mostrando mais familiares, e dialogar com elas mostrou-se, por fim, uma tarefa quase tranquila. Do susto à tranquilidade, devemos dizer que o caminho foi construído quando as tabelas, números e porcentagens deixaram de figurar como dados e passaram a compor o que 
chamamos de quadro de respostas. Entendendo os dados como retratos de um cotidiano construído na vivência escolar, o processo tornou-se mais próximo e, assim, foi-se desenvolvendo a atividade de dar vida aos números. Um dado que julgamos importante afirmar é que não nos ocupamos apenas em analisar aquilo que os gráficos apontavam como resposta da maioria. As hegemonias foram, sim, notadas e consideradas. Contudo, é preciso lembrar que cada uma das torres dos gráficos é formada por informações dadas por estudantes. Ou seja, são exemplares de um todo e de parte dele. Assim, se em uma sala de aula não podemos prestar atenção apenas no grupo de alunos que mais participa, também consideramos importante olhar para os dados menos assinalados, para os desvios padrões presentes nos índices dos gráficos. Afinal, cada um desses índices diz respeito a diferentes tipos de respostas/compreensões, ou dúvidas dos estudantes e, como tal, tem muito a dizer.

Antes de passar à análise dos dados, vale trazer algumas informações sobre o lugar onde a amostra problematizada neste artigo foi construída.

Florianópolis, capital do Estado de Santa Catarina tem, segundo dados do censo realizado em 2010 Instituto Brasileiro de Geografia e Estatísticas (IBGE), uma população de quase 500 mil habitantes. Ainda de acordo com o Instituto, a cidade conta com 2.712 docentes de Ensino Fundamental, 1.242 de Ensino Médio e 1.248 no Ensino Pré-Escolar. Sobre o número de matrículas, os dados são os seguintes: 48.627 estudantes matriculados no Ensino Fundamental, 16.937 no Ensino Médio e 10.874 no Ensino PréEscolar ${ }^{1}$. Tratamos, portanto, de uma capital de dimensões que poderiam ser definidas como medianas. Vale informar que se trata de uma cidade com a peculiaridade de ter seu espaço geográfico dividido entre Ilha e Continente, e onde os bairros apresentam caraterísticas muito específicas e diferentes, como é o caso, por exemplo, do badalado balneário de Jurerê Internacional (bairro de praia onde uma população local de camadas média e alta divide espaço com visitantes que vêm veranear em suas casas luxuosas), ou de

\footnotetext{
${ }^{1}$ Os dados sobre o município de Florianópolis estão disponíveis no site do IBGE. Disponível em: <http://cidades.ibge.gov.br/xtras/perfil.php?lang=\&codmun=420540\&search=santa-catarina $\mid \mathrm{f}$ lorianopolis|infograficos:-informacoes-completas>. Acesso em: 15 nov. 2016. O site do IBGE foi reformulado e atualmente os dados estão disponíveis em:https://cidades.ibge.gov.br/brasil/sc/ florianopolis/pesquisa/13/5902
} 
bairros como Ratones ou Vargem Grande (menos movimentados em termos turísticos e com maior número de moradores locais).

Respeitando as indicações da pesquisa, no momento de distribuir os questionários entre as escolas da cidade, deve-se afirmar que se procurou atentar para as peculiaridades da cidade, portanto, visando a tornar a amostra o mais perto possível da representatividade diversa de sujeitos do espaço florianopolitano.

\section{FORMAS, CONTEÚDOS E REPRESENTAÇÕES DA HISTÓRIA}

“O que significa a História para você?” A questão que abre o questionário foi, também, a primeira a ser analisada para este texto, e as respostas a ela despertaram grande curiosidade, afinal compreender o significado dado à disciplina, pelos estudantes, mostra-se como questão central para o processo de ensino e aprendizagem, bem como para uma reflexão sobre os usos que farão dela. Vamos começar a análise apresentando a representação gráfica que dá visibilidade aos dados comparativos da amostra florianopolitana, em relação com a amostra brasileira (Figura 1).

Percebe-se que os índices nacionais e de Florianópolis têm pouca variação para a questão e, neste sentido, ambas as amostras já sinalizam para a compreensão de que os/as estudantes de História comungam de uma compreensão muito semelhante/homogênea do que seja a História e do que é a sua finalidade como disciplina escolar. Para uma compreensão mais abrangente, cabe mapear as alternativas elencadas para a questão de № 1 em Florianópolis.

Como podemos notar, analisando as respostas dadas às 8 alternativas/ definições apresentadas, percebe-se que a maioria discorda que História seja apenas uma matéria da escola e nada mais, assim como concorda que ela possibilita a compreensão sobre o passado, sobre modos de vida do passado e sobre a própria vida do sujeito. 


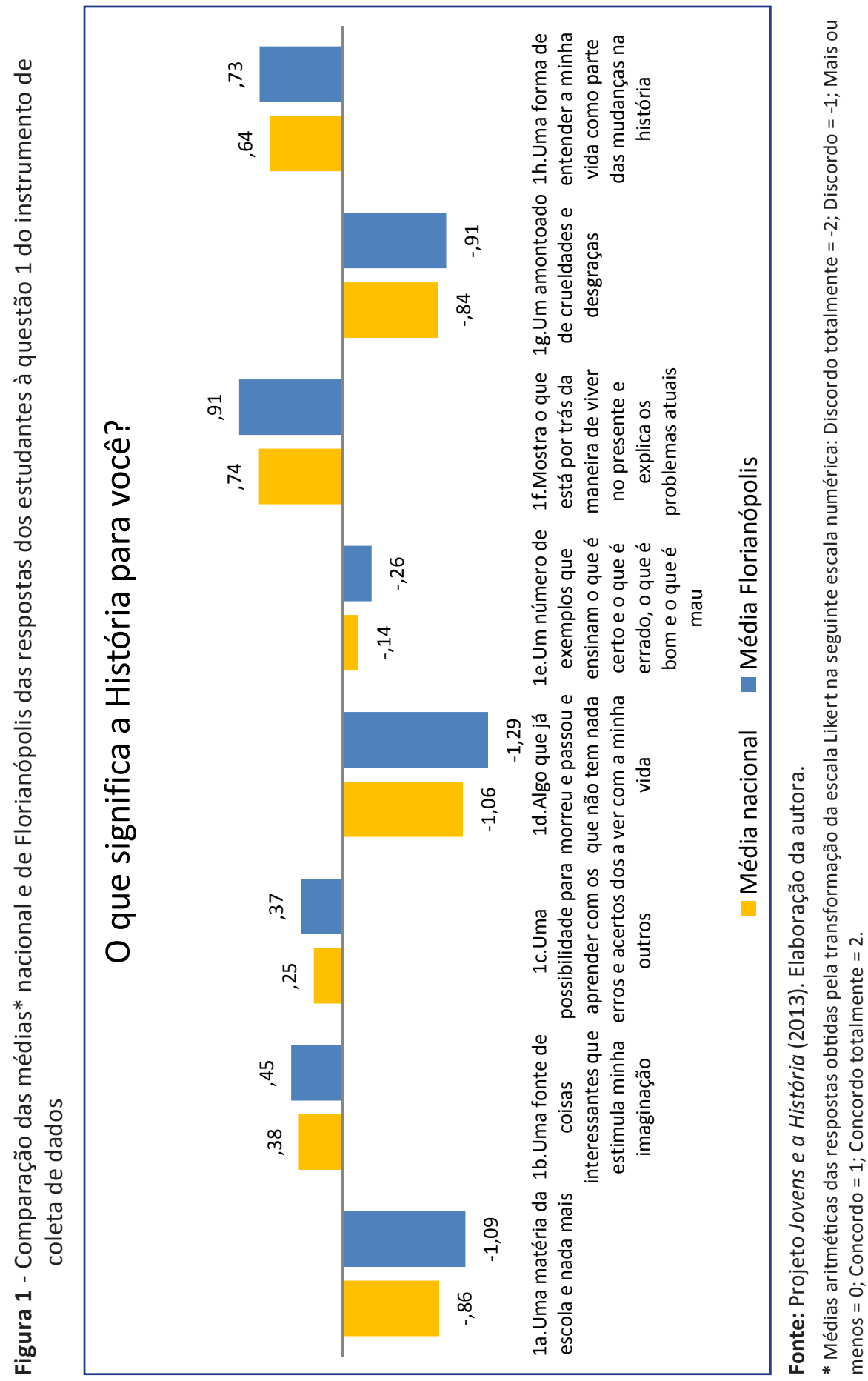


Figura 2 - Dados obtidos em Florianópolis das respostas dos estudantes à questão 1 , alternativa $A$ do instrumento de coleta de dados

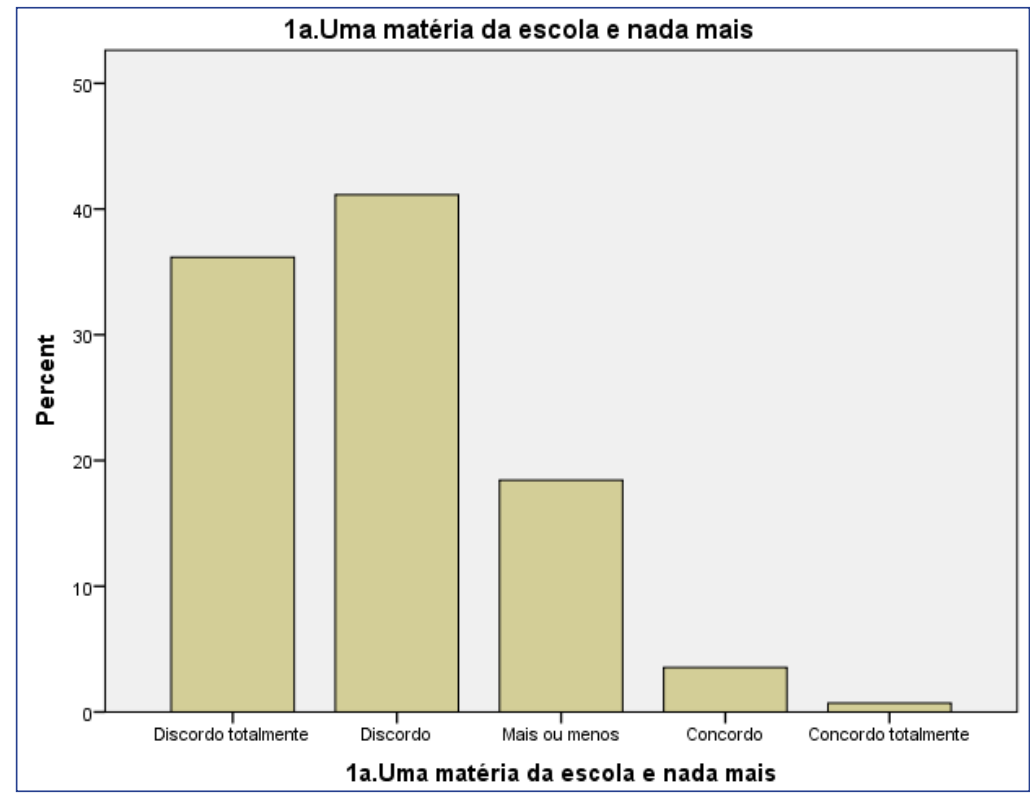

Fonte: Projeto Jovens e a História (2013).

O dado obtido para a alternativa A (figura 2) é o que evidencia a discordância quanto à afirmação de que a História é apenas uma matéria da escola e nada mais. Agregando as alternativas discordo totalmente e discordo, temos por volta de $75 \%$ de discordantes desta afirmação. Voltando ao gráfico anterior, vê-se que esse dado é bastante semelhante ao número nacional, e leva à reflexão, portanto, de que há um entendimento da História como algo para além da escola.

Por sua vez, a alternativa $C$ (Figura 3 ) pergunta aos entrevistados/ as se a História é uma possibilidade para aprender com os erros e acertos dos outros. As respostas a esta questão trazem uma tendência de concordância com a frase, onde $39 \%$ concordam e $10 \%$ concordam totalmente. Ou seja, evidencia-se a concordância de que a História tem possibilidade de servir de exemplo/modelo, ensinando ao presente, acertos e erros do passado. Contudo, não se pode fechar os olhos para o fato de que $34 \%$ assinalaram a opção neutra, indicada na expressão mais ou menos. O que este dado indica? Dúvida quanto à função do aprendizado por parte dos estudantes? 
Questionamento ao fato de que a disciplina tem mesmo como nos ensinar com erros e acertos do passado? É difícil formular hipóteses para estes questionamentos. Cremos, assim, que vale indicar que os/as estudantes dividem-se em relação à compreensão da disciplina ter o poder de ensinar/ mostrar os erros/acertos dos outros.

Figura 3 - Dados obtidos em Florianópolis das respostas dos estudantes à questão 1 , alternativa $C$ do instrumento de coleta de dados

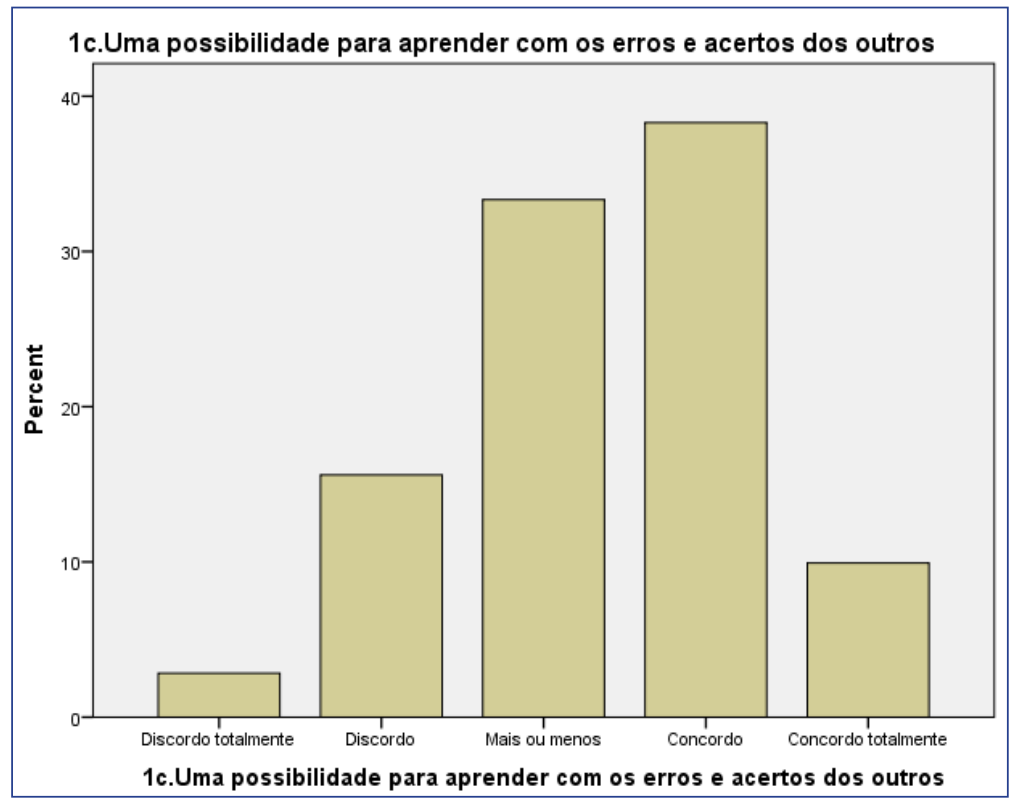

Fonte: Projeto Jovens e a História (2013).

A alternativa E (Figura 4) questiona se História seria "um número de exemplos que ensinam o que é certo e o que é errado, o que é bom e o que é mau". De certo modo, volta à questão de aprender com erros e acertos, mas, polarizando-os, coloca os estudantes frente a uma situação mais concreta da experiência de aprender com o passado. As respostas dadas a esta questão apontam para a dúvida/neutralidade dos estudantes, porque a maioria (49\%) assinalou a resposta neutra mais ou menos. Novamente, percebe-se que eles têm grande dúvida sobre o fato de que a História ensina através da exposição de erros/acertos dos outros. Sobre concordar/ discordar, é possível afirmar que houve certo equilíbrio, com vantagem para as opções que discordam da frase. Vejamos no gráfico: 
Figura 4 - Dados obtidos em Florianópolis, das respostas dos estudantes à questão 1, alternativa $\mathrm{E}$ do instrumento de coleta de dados

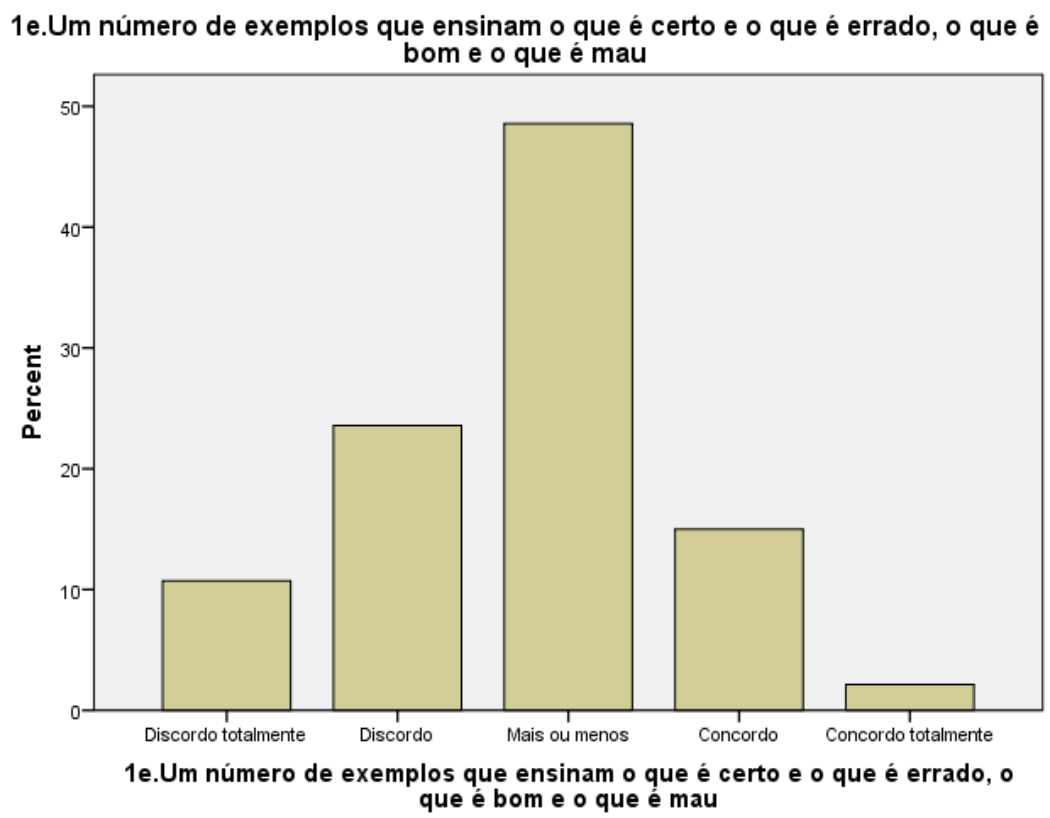

Fonte: Projeto Jovens e a História (2013).

A análise destes dados em conjunto leva a pensar que os estudantes tendem a concordar que há algum aprendizado com os erros e acertos do passado, mas têm certa dúvida sobre como essa relação se opera. Por outro lado, evidenciam que não acreditam que essa relação se equacione entre certo/errado, bom/mau.

Ainda na $1^{\mathrm{a}}$ pergunta, são relevantes as alternativas $\mathrm{F}$ e $\mathrm{H}$, que fazem os entrevistados refletirem sobre o significado da História frente a sua vida e à compreensão dos problemas atuais. Houve uma grande concordância com a afirmativa F, de que a História explica problemas atuais, onde predominaram as respostas concordo e concordo totalmente. Ocorre de modo semelhante em relação à assertiva de que é uma forma de entender a minha vida como partes das mudanças na história (alternativa $\mathrm{H}$, também predominância das respostas concordo e concordo totalmente). Relacionando as duas respostas, pode-se inferir que os estudantes de Florianópolis entendem que o estudo da História permite uma compreensão dos modos de vida 
e dos problemas atuais, bem como compreender que a sua própria vida é parte de tais mudanças.

Pelas respostas dadas à questão 1 , de modo geral, compreende-se que os/as estudantes que responderam aos questionários em Florianópolis entendem que a História lhes possibilita o aprendizado sobre questões do passado, sobre os modos de vida das pessoas e sobre a sua própria experiência como sujeitos. Contudo, parecem ter dúvidas ou rejeitar a ideia de que esse aprendizado seja feito através do ensino de certo/errado e bom/mau.

Vale insistir que tais dados, em comparação aos dados da amostra brasileira, trazem muitas semelhanças, indicando aspectos sobre os quais é importante refletir. Afinal, são indícios de uma maneira, de certo modo, homogênea de definir/significar a História na cultura escolar. Voltaremos a esta questão mais à frente, mas cabe alertar para o dado. E neste sentido, afirmar que as semelhanças da amostra de Florianópolis com a amostra brasileira não é exceção. Por exemplo, em texto que observa as resposta a esta mesma questão, dada por estudantes de Araguaína/TO, os pesquisadores Luís Fernando Cerri, Norma Lucia da Silva e Dafny Candido Machado concluíram que os estudantes da referida cidade também compreendem a História como matéria escolar que "abre seus olhos para o passado, adverte sobre sua existência, de modo que não passa despercebida" (CERRI; SILVA; MACHADO, 2016, p. 48).

Por sua vez, as pesquisadoras Virginia Cuesta e Cecília Linares, analisando e comparando as amostras de 4 países envolvidos na pesquisa, Brasil, Argentina, Uruguai e Chile, compreendem que, quanto à questão do significado da História, os jovens apresentaram tanto coincidências quanto alguns distanciamentos. Por um lado, concordam que a História mostra o que está por trás da maneira de viver no presente e explica os problemas atuais. Outra aproximação ocorre no entendimento de que a História é uma maneira de entender suas vidas como parte das mudanças que acontecem com o passar do tempo. Mas por outro, as pesquisadoras apontam que, se os brasileiros são mais neutros no que se refere ao entendimento de que a História representa um modo de aprender com os erros do passado, as amostras chilena, uruguaia e argentina indicam respostas mais assertivas para a questão (CUESTA; LINARE, 2014). 
Diretamente relacionada à primeira pergunta, a segunda questão indagou aos entrevistados qual sua opinião sobre os objetivos de estudar História. Nesse caso, ao preencherem suas respostas, deveriam opinar sobre a relação do ensino de História frente aos aprendizados possíveis sobre o passado, o presente e o futuro. Uma análise bastante significativa, ao colocar em questão as dimensões de análise frente ao tempo (Figura 5).

Figura 5 - Distribuição das respostas na amostra de Florianópolis à questão 2 do instrumento de coleta de dados (em porcentagens)

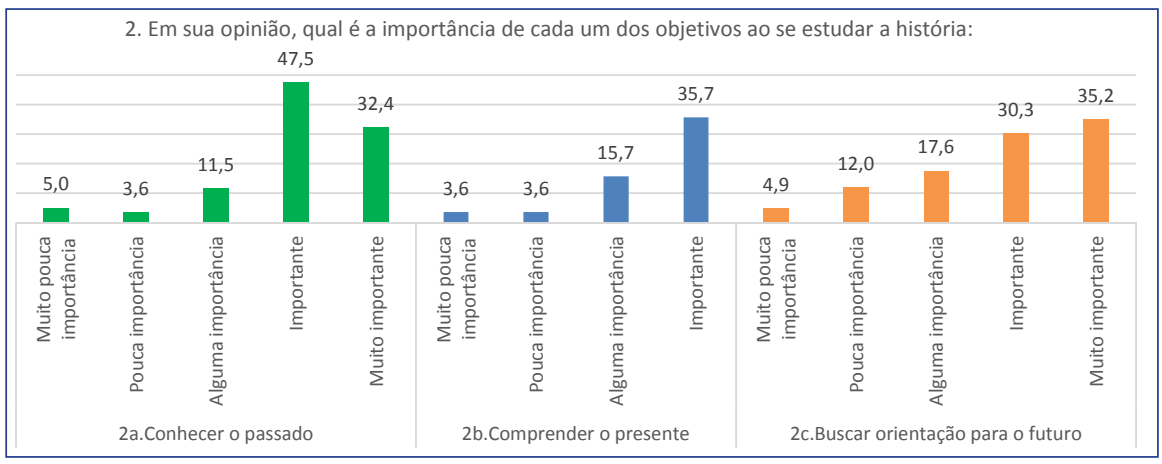

Fonte: Dados do Projeto Jovens e a História (2013). Elaboração da autora.

As respostas dadas à alternativa $\mathrm{A}$, e que se referem ao objetivo Conhecer o passado evidenciam uma concordância com a importância da relação da História com o passado. Não é um dado novo, mas não deixa ser relevante registrar o reconhecimento de que $80 \%$ dos estudantes concordam que estudar História, para conhecer o passado, é importante, e que este número aumenta para 90\%, se juntar as duas opções (importante e muito importante). Analisando a alternativa B (que indaga sobre o presente), constata-se que os estudantes também concordam que o estudo da História é importante para conhecer questões dos dias atuais, com uma pequena diferença que, neste dado, a alternativa muito importante foi a mais assinalada. Por fim, constatando a alternativa $C$, que destaca a relação História-orientação para o futuro, há, também, uma parcela significativa que concorda que esse estudo seja importante (31\%) ou muito importante (35\%). Contudo, chama atenção que, neste item, as respostas muito pouca importância, discordo e alguma importância que, juntas, representam $1 / 3$ das respostas, denotam mais discordância do que o observado nas alternativas 
A e B. Ou seja, ao que indicam os dados, os estudantes tendem a relacionar História-passado-presente-futuro, mas este último é alvo de dúvida para alguns.

Ainda considerando as questões relativas às impressões sobre a disciplina, as questões 3 e 4 perguntam sobre que formas em que a História aparece mais agradam e despertam confiança dos estudantes. Esses dados dimensionam opiniões diversas sobre materiais didáticos presentes no cotidiano da escola, também sobre aqueles que tematizam a História fora do espaço escolar. Analisar esses dados em conjunto mostra algumas questões importantes. A análise sobre gosto/confiança mostra que os livros escolares são vistos como confiáveis, embora os estudantes declarem pouco gosto por eles. Neste caso, vale afirmar que dados locais são próximos aos encontrados nacionalmente.

De forma semelhante, é grande a confiança em documentos e outros vestígios, com uma curiosidade: eles confiam mais do que gostam de documentos e outros tipos de vestígios. Isto considerando que as respostas gosto pouco, muito pouco e a alternativa mais ou menos foram pouco assinaladas.

Romances históricos, novelas e minisséries não são vistos como confiáveis. O gosto dos estudantes em relação a eles é bastante equilibrado, variando entre o gosto e gosto pouco. Com relação aos filmes, as respostas são positivas, no que diz respeito ao gosto, mas são tensas em relação à confiabilidade. Em outras palavras, há uma tendência forte para gostar dos filmes ( $80 \%$ gostam ou gostam muito) e para confiar neles, mas as respostas que denotam a não confiança não podem ser desconsideradas (por volta de $33 \%$ assinalaram confiar pouco/muito pouco e $35 \%$ optaram pela resposta neutra - mais ou menos). Ainda sobre linguagens audiovisuais, cabe informar que os documentários de TV são apreciados por parcela significativa, e que também são vistos como confiáveis.

Os dados sobre o gosto/confiança em relação às falas dos professores trazem uma indicação de apreciação por parte de $62 \%$, mas o índice de confiança é maior quando postas juntas as expressões confio e confio muito, pois se chega a $81 \%$ das respostas. As falas de outros adultos são apreciadas também, mas, neste caso, o grau de confiabilidade é menor, tanto na própria relação gosto/confiança, quanto se comparadas com o 
grau de confiabilidade com os professores. Sobre os índices obtidos nesta questão, vale apontar para a centralidade de função docente no processo de ensino e ressaltar, ainda, a importância das escolhas dos professores, visto que elas têm grande influência no modo como os estudantes percebem a História. Os professores são vistos com falas autorizadas pelo grupo de estudantes e, como tal, justamente o ponto de partida para um aprendizado significativo da disciplina.

Se os dados analisados aqui alcançam as impressões e interesse/ gosto dos estudantes, outras questões trazem algumas dimensões sobre o processo da aula de História. Analisar esses dados traz importantes questões sobre como estudantes percebem a aula e como a leem enquanto processo de ensino. Neste sentido, cabe refletir, também, sobre as questões 5 e 6, verificando pontos específicos de intersecção entre elas. Vejamos:

A pergunta 5 (Figura 6) pediu que respondessem: O que normalmente acontece durante as aulas de História? As oito (8) alternativas dispostas propunham ponderações sobre diferentes atividades: desde ouvir exposições dos professores, discutir diferentes explicações, pesquisar/fazer trabalhos de teatro ou visitas a museus, usar livros e recordar/reinterpretar eles próprios. Observa-se que as exposições dos professores sobre o passado figuram como metodologia mais utilizada, sendo assinalada como frequente ou quase sempre por aproximadamente $82 \%$.

Outro dado visto como frequente/quase sempre é a utilização de algum material didático, como livro, apostila ou xerox: também numerado acima dos $70 \%$. O uso de documentos - lembrando que eles foram atestados como algo que os estudantes confiam - não parece ser muito comum. Os índices às vezes/quase nunca e nunca, somados, são maiores do que o anunciado nas opções frequentemente/quase sempre. O uso de filmes, música e $C D$ também trazem maior indício de ser utilizado esporadicamente. Por sua vez, atividades interdisciplinares e/ou artísticas e visitas a museus parecem ser ainda mais reduzidas, como se verifica nas respostas compiladas. Um dado importante quanto a dinâmicas das aulas precisa ser destacado: os estudos feitos em sala contemplam (frequentemente/quase sempre) diferentes explicações, segundo entende a maioria. 


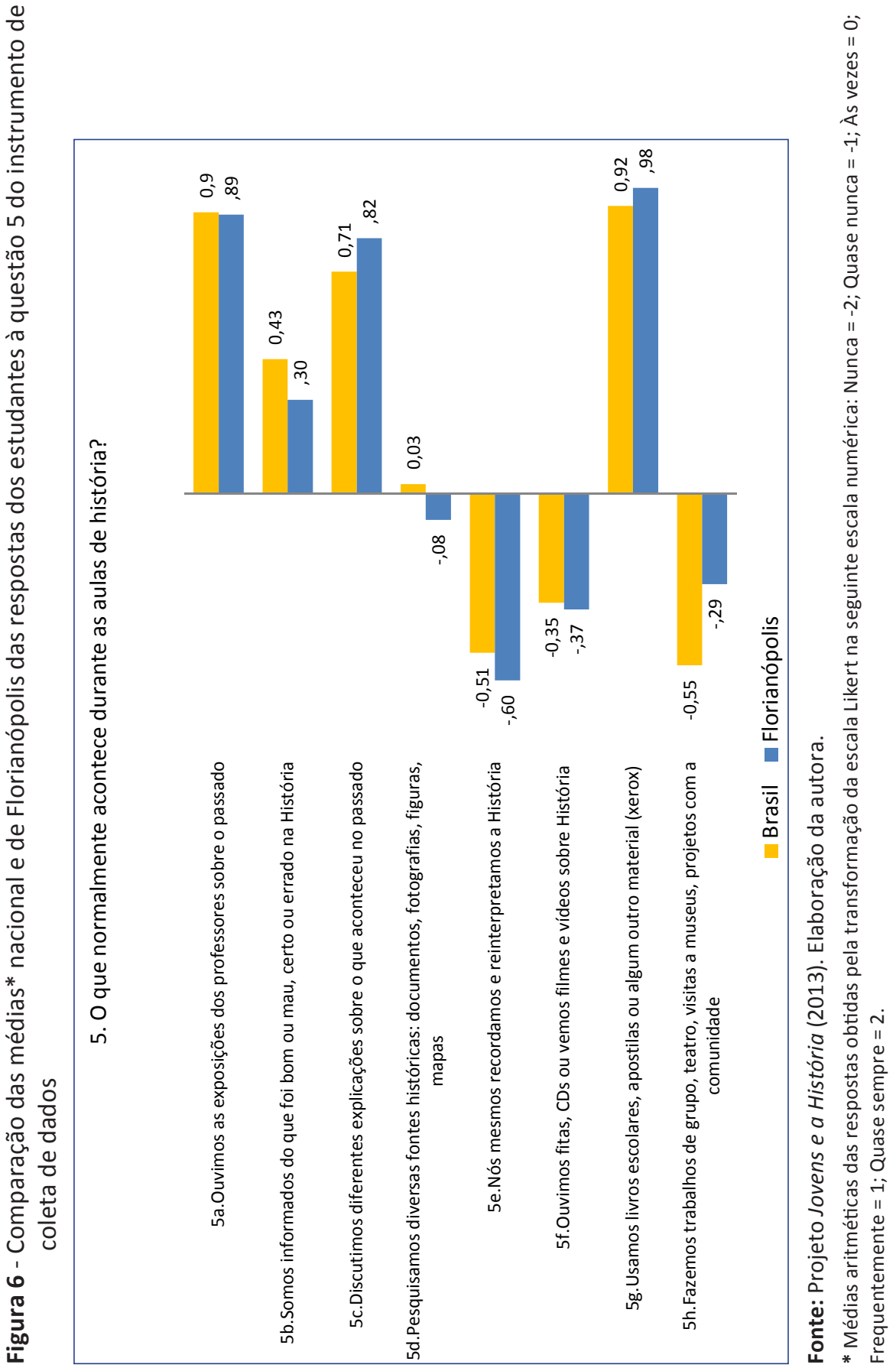


A questão 6 procurou investigar os detalhes do processo da aula que, na pergunta anterior, foram questionados. Nela, a pergunta central é: Em que suas aulas de História se concentram, sendo apresentadas oito (8) assertivas que distribuem proposições associando conhecimento dos fatos, compreensão da situação do mundo hoje e no passado, uso de vestígios históricos e valorização, etc. A seguir, as respostas dadas para a Alternativa E, que propõe: Usamos a História para entender a situação do mundo e descobrir as tendências de mudança.

Figura 7 - Respostas dos estudantes à alternativa E - Questão 6 do instrumento de coleta de dados

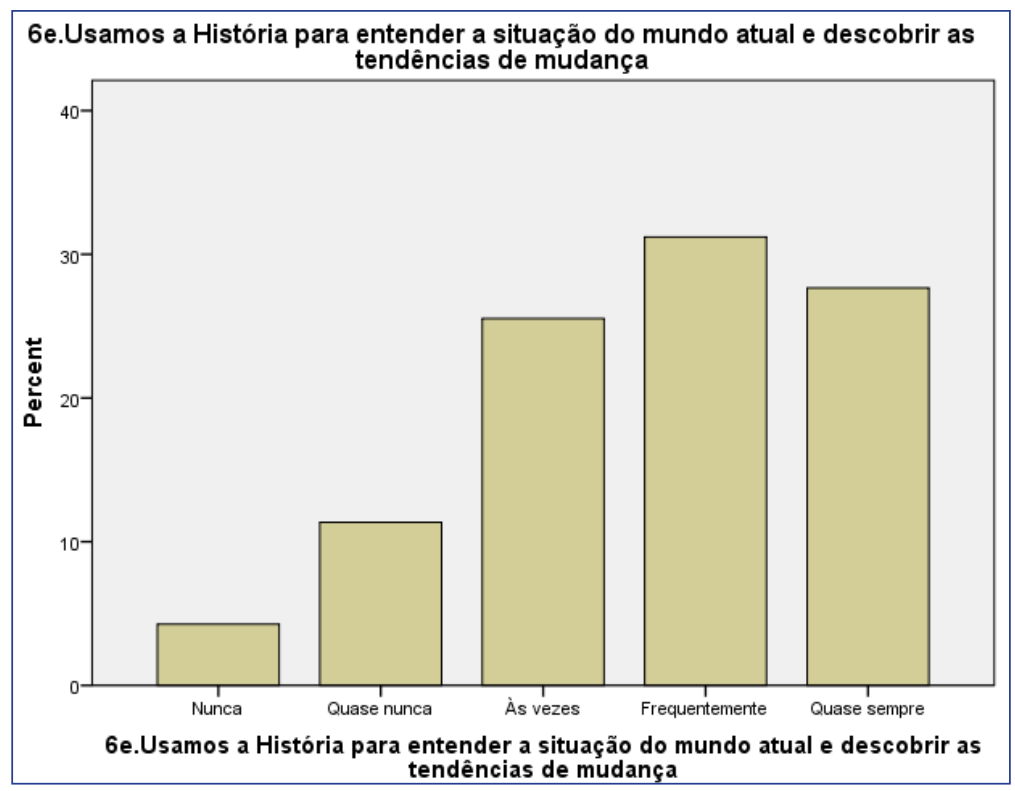

Fonte: Projeto Jovens e a História (2013).

Esta questão trouxe índices distribuídos de modo parecido nas respostas às vezes, frequentemente e quase sempre, com tendência maior para concordar com a afirmação. Vê-se, aqui, que os estudantes avaliam suas aulas de História como espaço de estudo sobre as situações do mundo no presente. Cabe perguntar: este aspecto pode exercer alguma influência sobre a concepção de História desses/as estudantes? Pelo que esses dados apontam, é possível inferir que sim! Afinal, observando-os, percebemos, na questão em análise, que as respostas apontam para um uso prático dos 
conteúdos de História em relação a temas atuais. Ainda, se somarmos a ela a concepção de utilidade assinalada na questão 1, este dado se configura novamente. Como foi apontado, os estudantes entendem que a História lhes permite uma compreensão sobre si e sobre o mundo, para além da escola. Voltarei ao assunto mais à frente (no momento de concluir o texto), mas adianto que é possível acreditar que as relações estabelecidas entre passado-presente, nas aulas de História, têm permitido outras significações para o estudo da disciplina e, consequentemente, para a concepção de história dos/as estudantes.

Como uma última questão para análise, recorro à de número 26, que propõe aos estudantes que escolham, entre 6 expressões, aquela que melhor descreve o desenvolvimento a História.

Figura 8 - Respostas da amostra de estudantes de Florianópolis à questão 26 do instrumento de coleta de dados (em porcentagens)

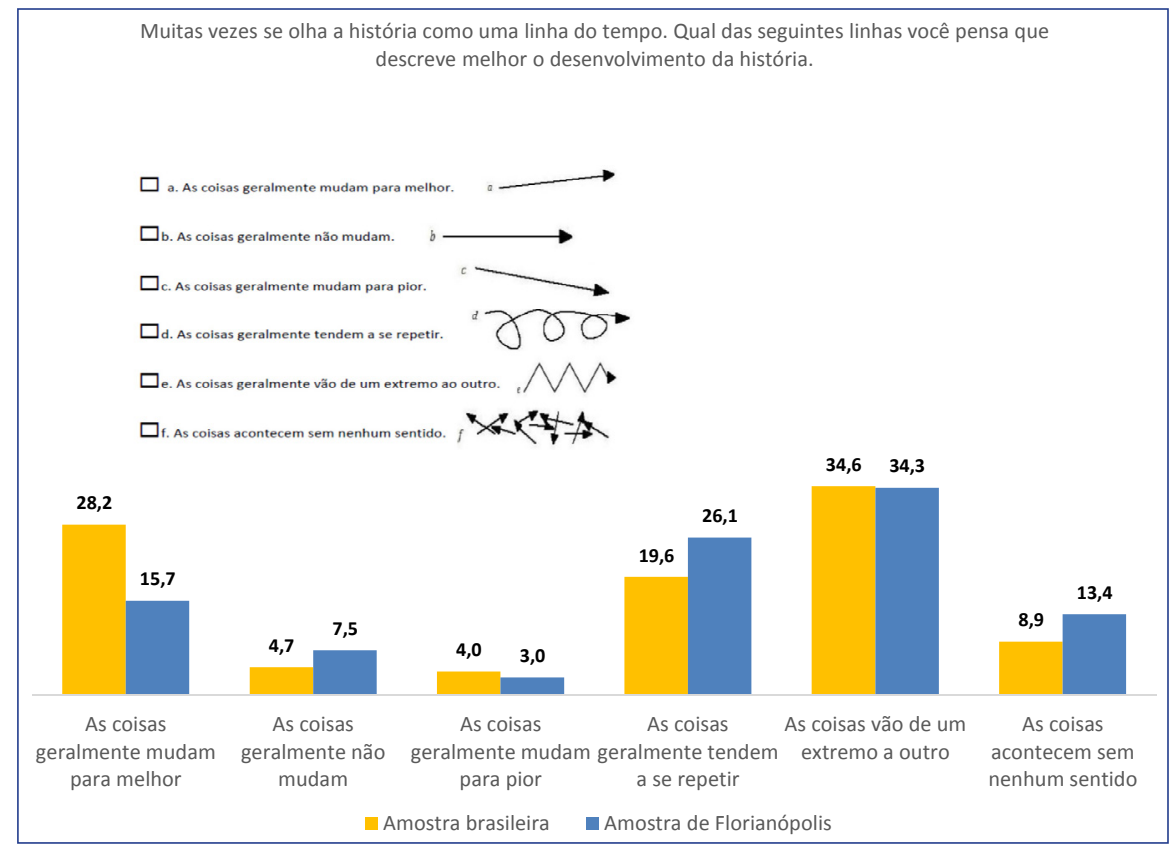

Fonte: Projeto Jovens e a História (2013). Elaboração da autora.

As alternativas para análise propunham diferentes avaliações, que vão desde uma evolução positiva do tempo, permanência, relações de repetição, 
piora ou, ainda, de caos total. Em Florianópolis, a alternativa E, as coisas vão de um extremo ao outro, foi a mais assinalada, seguida da alternativa $\mathrm{D}$, que propõe que as coisas geralmente tendem a se repetir. Analisando em conjunto as duas respostas, pode-se afirmar que os jovens entendem o processo histórico como algo dinâmico, e que não necessariamente responde à evolução de melhoria. Ainda é possível perceber que os dados da amostra florianopolitana são similares aos da amostra brasileira.

A resposta a esta questão apresenta um aspecto muito importante em termos de objetivo geral do aprendizado histórico, que evidencia o esforço pela compreensão da História como um processo. Como se vê, muitos assinalaram a linha do tempo da alternativa E, que traz que as coisas vão de um extremo ao outro, respondendo, portanto, que entendem que os momentos se intercalam, mesmo em diferentes e opostas situações. Por outro lado, não são poucos os estudantes que assinalaram as linhas que trazem a história das coisas que mudam para melhor ou que permanecem iguais ou se repetem. Acreditamos que essas formas de compreender a passagem do tempo e os acontecimentos que nele têm espaço dialogam com os demais dados apresentados pelo grupo de estudantes, no que se refere às perguntas aqui analisadas. Percebemos, por exemplo, tais aproximações comparando a compreensão que apresentaram sobre o significado da História. Quando analisados os dados da pergunta 1 , percebeu-se que parte significativa do grupo compreende a História com um modo de conhecer/explicar o que aconteceu no passado, e que tais compreensões ajudam a entender os problemas atuais. Ou seja, entendem as relações entre passado e presente e percebem as mudanças como parte da História. É pertinente lembrar, ainda, que não há homogeneidade na compreensão de que tais mudanças sejam compostas por bons/maus exemplos. Reportando esses dados à questão da linha do tempo, portanto, entendo que as respostas se complementam. O grupo de estudantes assinala com maioria a compreensão da História e um desenrolar de altos e baixos, mas há, ainda, a indicação, por parte deles, de que esse processo é de melhoria ou de estagnação. Pensando no quadro de respostas como o retrato de uma sala de aula, tem-se, assim, um cenário 
ainda a ser compreendido melhor pelos estudantes, no que diz respeito ao entendimento do processo histórico como um todo.

\section{CONSIDERAÇÕES FINAIS}

A intenção central desta reflexão foi analisar as diferentes compreensões dos estudantes de Florianópolis face ao ensino de História - seus objetivos e processos - para, em diálogo com os demais dados da Pesquisa Jovens e a História mapear questões relativas as suas vivências e ao processo de desenvolvimento do aprendizado histórico.

Pelas questões analisadas, conseguiu-se perceber que, de maneira geral, os dados obtidos na cidade em questão não diferem daqueles coletados no Brasil ou nos demais países. Os jovens de Florianópolis fazem uma leitura do ensino de História entendendo a disciplina como parte importante de seu aprendizado. A negação da afirmação de que a História é apenas uma matéria escolar leva a crer que há uma compreensão dela como parte da formação desses estudantes como sujeitos em seu tempo e espaço. Outras respostas também justificam esta reflexão. Entre elas, as alternativas em que os estudantes declaram entender que o estudo da História, partindo do passado, ajuda/participa da compreensão sobre questões do presente.

Os dados apresentados permitem que muitas reflexões sejam feitas e, como forma de trazer conclusões a este texto, são apresentadas algumas ponderações/constatações que, longe de encerrar o debate, pretendem-se ser instrumentalizadoras de outros trabalhos.

A primeira ponderação que precisa ser feita diz respeito à constatação de um padrão nas respostas obtidas juntos aos questionários, que reportam ao conceito de código disciplinar enunciado pelo pesquisador espanhol R. Cuesta Fernandez (1997).

De acordo com o referido pesquisador, o código disciplinar da História:

Se puede definir como el conjunto de ideias, valores, suposiciones, reglamentaciones y rutinas práticas (de caráter expresso o tácito) que a menudo se traducen em discursos legitimadores y em linguajes públicos sobre el valor educativo de la História, y que orientam la prática professional de los docentes. En suma, el elenco de ideias, discursos y 
práticas dominantes em la enseñanza de la história dentreo del marco escolar (CUESTA FERNANDEZ, [s.d., s.p.]).

A investigação de Cuesta Fernandez evidenciou que este cânone construído sobre a História como disciplina escolar é resultado e influência direta do processo de construção da escola e de suas funções sociais, políticas e escolares. Em um cruzamento direto de motivações, escola e disciplinas escolares são, portanto, tradições inventadas e, como tal, precisam ser compreendidas.

Pesquisadores da História do Ensino de História no Brasil ajudam a perceber esse processo em nosso país, apontando os diferentes empreendimentos políticos e sociais que moldaram (e moldam) a História como disciplina escolar. A pesquisa realizada pela historiadora Thais Nivia de Lima Fonseca (2011) aponta para a trajetória da História desde o momento de sua efetivação como disciplina escolar, no século XIX, e as questões apontadas justamente reforçam a compreensão de como a disciplina foi sendo moldada, respondendo a certos princípios e normativas que, ao longo do tempo foram sendo consolidados como próprios do fazer histórico escolar. A saber: a ideia de identidade nacional, as noções de pátria/ patriotismo, nação/ nacionalismo e o conhecimento dos fatos e heróis do passado nacional. A propósito, esse rol de elementos formalizadores dos objetivos do ensino de História está muito próximo do que define Cuesta Fernandez, que concluiu:

Si [...] tuviéramos que resumir, y por tanto simplificar, los rasgos más sobressalientes que resultan de este processo constituyinte, podríamos decir que los discursos y práticas próprios del código disciplinar se alimentan de las siguientes notas distintivas: arcaísmo, nacionalismo, elitismo y memorismo (CUESTA FERNANDEZ, [s.d., s. p.]).

Analisando as respostas obtidas com os questionários, alguns desses princípios e normativas podem ser percebidos. Eles podem ser notados quando se reporta, por exemplo, à questão sobre o significado da História (questão 1), sobre o objetivo de estudar História (questão 2) ou, ainda, na questão sobre a metodologia das aulas (questão 5).

Quando os dados obtidos para as questões 1 e 2 foram analisados, percebeu-se que parte significativa do grupo de estudantes tem a compreensão 
de que a História ensina pelos exemplos de certo/errado do passado. É importante lembrar: na Questão 1, os dados mostraram que maioria do grupo discorda que a História seja uma matéria e nada mais, e que boa parte deles concorda que ela seja algo para além da História. As respostas trazem, ainda, a compreensão positiva frente à assertiva de que o estudo da História mostra o que está por trás da maneira de viver no presente e explicando os problemas atuais. Na questão 2 foi visto que os estudantes entendem que o estudo da história é importante/muito importante para conhecer o passado; é importante/tem alguma importância para a compreensão do futuro e, por fim, é muito importante/importante para buscar orientação para o futuro. Por sua vez, na questão 5 pode-se ler a compreensão da maneira como ocorrem as aulas de História. A compreensão do grupo sobre o fazer escolar trouxe dados que lembram da centralidade da fala dos professores e dos manuais didáticos no processo de ensino.

Como dito, a percepção de que padrões comuns no fazer cotidiano do ensino de História persistem ao longo do tempo - ainda que sejam, hoje, reinventados - está explicitada nesses dados. Voltando ao conceito de código disciplinar e as marcas identificadas por Cuesta Fernandez, tem-se o traço da história como uma disciplina exemplar, que volta ao passado para trazer elementos para a compreensão do presente. Algo que é feito sobremaneira tendo, nos professores e nos manuais didáticas, seus principais interlocutores; também como visto nas respostas.

Cabe apontar, no entanto, que se há a presença desses traços históricos do código disciplinar nos dados coletados, também é possível afirmar que os questionários trazem evidências de que, além da tradição, o ensino de História tem muito de renovação. Nas questões aqui analisadas, esses traços ficam mais dimensionados quando trazem indícios da compreensão da História como algo sobre o que os estudantes podem emitir opiniões, construir hipóteses ou, ainda, fazer relações. Na verdade, deve-se lembrar de que essa possibilidade de viver o aprendizado como algo que se pode viver de modo crítico é, também, parte do histórico da História como disciplina escolar. Esse aspecto tem sido objetivo de professores e professoras 
de História no Brasil desde que, nos anos de 1970 e 1980, lutou-se para a manutenção da disciplina no currículo escolar brasileiro.

Voltando à questão que iniciou este texto e pensando sobre a função do aprendizado histórico, devo dizer que perceber, nas respostas às questões analisadas, a presença da tradição e da renovação na disciplina não chega a ser uma surpresa. O questionário, a propósito, não dá um cenário hegemônico - e não é esta mesmo a sua pretensão. Assim, se não temos hegemonia, encontramos, nesse cenário, muitas percepções sobre a História que se faz no dia a dia escolar. Reitero que julgo importante encontrar, nas respostas, indícios que apontam para a vivência/ gosto enunciado pelos estudantes quanto às atividades de formalizar/ comparar/ construir hipóteses/ideias e estabelecer relações entre passado e presente. Também é salutar que vejam o estudo da História como forma de pensar/projetar o futuro. As incertezas estão presentes e penso que não comprometem, pelo contrário, fazem parte do quadro aqui desenhado - por muitas razões e, entre elas, pelo fato de que nem sempre os estudantes de História se definem como apreciadores da disciplina, ainda que reconheçam a sua relevância. Em outras palavras, se buscamos, aqui, compreender como os estudantes de História vivenciam o ensino de História e como definem seus objetivos no espaço escolar, podemos afirmar que esses estudantes, seguindo o que disseram outros/as jovens, repetem um padrão de enunciar respostas que indicam acordo com a importância da disciplina em sua vida escolar, ainda que não digam se gostam disso ou não. Trata-se do reconhecimento de um aspecto político e social, inclusive, haja vista que é justamente por esta questão - permitir que conheçamos o nosso passado para compreender o nosso presente - que a disciplina tem se mantido nos currículos escolares.

Pensando sobre esta questão, é importante lembrar que os estudantes de Florianópolis entendem que o estudo da História permite uma compreensão dos modos de vida e dos problemas atuais, bem como compreendem que a sua própria vida é parte de tais mudanças. Neste sentido, cabe lembrar os textos do teórico alemão Jörn Rüsen, especialmente em suas formulações sobre o aprendizado histórico. De acordo com ele, o aprendizado histórico é um processo complexo que envolve diferentes dimensões das 
experiências relativas ao passado, dos sujeitos e de seus grupos, individuais e coletivas dos sujeitos e de seus grupos dos sujeitos (RÜSEN, 2010). Assim, aprender História é uma experiência onde o pensamento histórico é desenvolvido não por meio de um acúmulo de conhecimentos, mas pela mobilização deles. Ainda, aprender História é mobilizar o passado para, ao compreendê-lo, poder projetar questões e compreensões para o presente e o futuro (RÜSEN, 2010).

Finalizando, portanto, fica a constatação de que os dados aqui analisados permitem inferir grande potencialidade para o trabalho de professores e professoras de História. Os estudantes evidenciaram, de diferentes modos, a compreensão da importância da disciplina em sua formação, denotaram sensibilidade na reflexão sobre os objetivos dela; elencaram o entendimento da necessidade de estabelecer relações críticas entre o passado e o presente; bem como apontaram muitos pontos sobre os quais também se fazem necessárias problematizações.

\section{REFERÊNCIAS}

BLOCH, Marc. Apologia da História, ou, o Oficio do Historiador. Rio de Janeiro: Jorge Zahar Ed, 2001.

CERRI, Luís Fernando; SILVA, Norma Lucia da; MACHADO, Dafny Cândido. Elementos das concepções históricas de estudantes de ensino médio em Araguaína, TO. In: MORAIS, Sérgio Paulo. (Org.). Noções Históricas: Ensino e Experiências Contemporâneas. São Paulo: Verona, 2016. P. 39-58

CUESTA, Virginea; LINARE, Cecilia. La enseñanza y el aprendizage de la História desde la mirada de los jovens em el cono Sur. Disponível em: <http://www.fhuc.unl.edu.ar/materiales_congresos/CD_ensenanza_ historia_2014/pdf/nucleo_2/cuesta_lnare.pdf>. Acesso em: 12 out. 2016. CUESTA FERNANDEZ, Raimundo. El código disciplinar: un marco interpretativo y algumas ideias para la explicación de la evolución de la História como material escolar em Espana. S/D. Disponível em: <http:// www.fedicaria.org/pdf/1.pdf >. Acesso em: 10 set. 2017. 
FONSECA, Thais Nivia de Lima. História e Ensino de História. Belo Horizonte: Autêntica Editora, 2011.

Instituto Brasileiro de Geografia e Estatísticas. https://cidades.ibge.gov. br/. Acesso em 15 de novembro de 2016

RÜSEN, Jörn. Experiência, interpretação, orientação: as três dimensões da aprendizagem histórica. In SCHIMIDT, Maria Auxiliadora; BARCA, Isabel; MARTINS, Estevão. Jörn Rüsen e o ensino de História. Curitiba: Ed. UFPR, 2010, p. 79-91. 


\section{ENSINO DE HISTÓRIA E FORMAÇÃO PARA A CIDADANIA: REFLEXÕES SOBRE A INTENCIONALIDADE NO ENSINO DE HISTÓRIA COMO ELEMENTO DE FORMAÇÃO HISTÓRICA, POLÍTICA E CIDADÃ}

Marizete Lucini

\section{DOS CAMINHOS QUE NOS CONDUZEM A ESSA REFLEXÃO}

- Se eles não fazem lá, nós fazemos aqui (Levante Popular da Juventude, 2016) ${ }^{1 .}$

- A nossa dificuldade em conseguir formar um pensamento é muito maior da de vocês. Nós temos que ver tudo que a mídia nos passa. Fazer um processo de compreensão, de seleção, prá daí a gente conseguir ver do que a gente vai ser a favor e do que a gente vai ser contra. [...] Uma escola sem partido é uma escola sem senso crítico, é uma escola racista, é uma escola homofóbica. [...] Nós temos uma história e nessa história a gente luta contra isso. O movimento estudantil nos trouxe um conhecimento muito maior sobre política e cidadania do que todo tempo que estivemos sentados e enfileirados em aulas padrões. Uma semana de ocupação que nós estamos nos trouxe mais conhecimento de política e cidadania do que muitos outros anos que a gente vai ter em sala de aula. [...] Nós nos tornamos cidadãos comprometidos [...] (Ana Júlia, 2016).

Este texto objetiva discutir a relação entre Ensino de História e Cidadania. Origina-se de reflexões que realizamos ao considerar os resultados da pesquisa Os Jovens e a História e ações contemporâneas que têm mobilizado jovens brasileiros na defesa de seus direitos. Questionamos em que medida o Ensino de História tem contribuído para o exercício da cidadania evidenciada durante as mobilizações protagonizadas por jovens estudantes, organizados ou não em movimentos sociais.

As epígrafes anunciadas no início deste texto apontam para protagonismos juvenis. Nas palavras de Ana Júlia, “trouxe um conhecimento muito maior sobre política e cidadania do que todo tempo que estivemos sentados e enfileirados em aulas padrões". A afirmação é, no mínimo, intrigante, se pensarmos que, como indica Audigier (2016, p. 25), "há mais de um século,

\footnotetext{
${ }^{\mathbf{1}}$ Fala de Paloma Fontes de Oliveira, militante do Levante Popular da Juventude de Sergipe à pesquisadora, São Cristóvão/UFS, agosto de 2016.
} 
a história escolar é pensada como uma contribuição de peso para a formação do cidadão". Para este autor, assim como para nós, esta seria uma evidência que tem orientado nossas ações no campo do Ensino de História.

Contudo, diante de afirmações como a destacada na epígrafe, esse caráter evidente que atribuímos à História escolar pode não ser tão evidente para todos os sujeitos, necessitando que nos detenhamos na análise do papel do Ensino de História no desenvolvimento da cidadania. Para tanto, parece necessário refletirmos sobre o que tem sido ensinado e que concepções esse ensino tem proporcionado aos jovens estudantes que os mobilizam ou não para ações cidadãs. Apresentaremos os resultados da pesquisa Os jovens e a História sobre uma questão que consideramos fundamental para pensar a intencionalidade da formação histórica, qual seja, a da História ensinada na percepção dos jovens participantes da pesquisa.

Importa destacar que, ao nos referirmos à formação histórica, entendemos com Cerri que ela "depende apenas em parte da escola, e precisamos considerar com interesse cada vez maior o papel dos meios da comunicação de massa, da família e do meio imediato em que o aluno vive" (CERRI, 2011, p. 44).

Contudo, antes de avançarmos na especificidade do conceito de consciência histórica ${ }^{2}$, neste texto, propomos, primeiramente, refletir sobre o conceito de consciência a partir de Ernani Maria Fiori, que prefacia o livro Pedagogia do Oprimido, clássica obra de Paulo Freire.

Para Fiori (1987, p. 14-15),

A consciência é essa misteriosa e contraditória capacidade que tem o homem de distanciar-se das coisas para fazê-las presentes, imediatamente presentes. É a presença que tem o poder de presentificar: não é representação, mas condição de apresentação. É um comportar-se do homem frente ao meio que o envolve, transformando-o em mundo humano. [...]

Mas ninguém se conscientiza separadamente dos demais. A consciência se constitui como consciência do mundo.

\footnotetext{
${ }^{2} \mathrm{O}$ texto de Luis Fernando Cerri, intitulado Ensino de História e consciência histórica: implicações didáticas de uma discussão contemporânea (São Paulo: FGV, 2011), apresenta discussões que possibilitam compreender o conceito de consciência histórica em diferentes autores.
} 
Consciência que difere de conscientização, mas que é condição para que ocorra a ação que, aliada à reflexão, constitui-se em práxis. Nas palavras de Freire (1979, p. 15), “a conscientização implica, pois, que ultrapassemos a esfera espontânea de apreensão da realidade, para chegarmos a uma esfera crítica na qual a realidade se dá como objeto cognoscível e na qual o homem assume uma posição epistemológica”.

Na sequência da discussão empreendida por Freire na obra Conscientização - Teoria e Prática da Libertação: Uma Introdução ao Pensamento de Paulo Freire, o autor indica que conscientização é, também, consciência histórica, “é inserção crítica na história, implica que os homens assumam o papel de sujeitos que fazem e refazem o mundo. Exige que os homens criem sua existência com um material que a vida lhes oferece" (FREIRE, 1979, p. 15).

Essa compreensão de consciência como consciência histórica e como inserção crítica na História remete a considerar que a consciência histórica pressupõe uma ação em relação à realidade que nos circunda. Realidade que é histórica, se entendermos que o presente é uma composição temporal que reúne as experiências humanas em movimento. Experiências humanas que congregam uma historicidade constituída e constituinte de uma mundanidade vivida por diferentes sujeitos individuais e coletivos. Sujeitos que se colocam em movimento a partir de uma consciência histórica que resulta e produz uma inserção crítica na história. Inserção que necessita de uma consciência cidadã e política para se colocar em movimento e, como anunciado na epígrafe que abre esse texto, possibilitar que, "se eles não fazem lá, nós fazemos aqui"3. $\mathrm{Na}$ esteira deste pensamento que se situa em uma concepção de educação libertadora, nossa atenção volta-se para um autor que se aproxima da perspectiva de entender consciência em uma perspectiva política em discussões relativas ao ensino de História. E é precisamente em um livro organizado por Selva Guimarães, intitulado Ensino de História e Cidadania que acessamos o texto de François Audigier.

\footnotetext{
${ }^{3}$ Fala de Paloma Fontes de Oliveira, militante do Levante Popular da Juventude de Sergipe à pesquisadora, São Cristóvão/UFS, agosto de 2016.
} 
Audigier (2016) aponta três dimensões como constituintes da consciência: a consciência histórica, a consciência cidadã e a consciência política. Neste texto, optamos por trabalhar com essa perspectiva, porque intencionamos refletir sobre a consciência cidadã e sobre a consciência política como âmbitos que necessitam estar presentes no ensino de História para instrumentalizar os sujeitos ao protagonismo das lutas sociais contra o preconceito, contra o racismo, contra a homofobia, contra o sexismo, contra a desigualdade social e contra toda forma de opressão. Nesta opção, expressamos nossa concordância e defesa do pensamento freireano, para quem, "além de um ato de conhecimento, a educação é também um ato político" (FREIRE, 1986, p. 25).

Audigier (2016) entende, por consciência histórica, "o privilégio do homem moderno de ter plena consciência da historicidade de todo presente e da relatividade de toda opinião" (GADAMER apud AUDIGIER, 2016, p. 27). Portanto, para esse autor, a consciência histórica ocorre quando o sujeito se percebe parte de uma continuidade histórica, em que o passado é parte de quem somos no presente, e pode ser interpretado sob diferentes perspectivas. Nesse campo, parece adequado apontar que os conteúdos escolares desenvolvidos a partir da ciência de referência, a História, são fundamentais no desenvolvimento da consciência histórica, pois somente ao conhecer a História é possível tomar consciência das ações humanas que nos conduziram ao presente que conhecemos.

Por consciência cidadã, o autor compreende a percepção dos sujeitos de pertencimento a uma comunidade, um grupo social, "uma comunidade política baseada hoje na igual dignidade de seus membros, na igualdade jurídica e na soberania que eles exercem conjuntamente, em particular sobre o fato de que os cidadãos controlam os poderes públicos que exercem no seio dessa comunidade" (AUDIGIER, 2016, p. 27). No desenvolvimento da consciência cidadã estão presentes elementos que não são necessariamente abordados como conteúdo histórico, mas que circundam as temáticas em diferentes acontecimentos históricos ou atores sociais com os quais seja possível estabelecer relações de identificação, seja por pertencimento étnico, de gênero, de classe, de cultura, de profissão, de geração, etc. 
A consciência política, na reflexão realizada pelo autor, relaciona-se à consciência cidadã, pois a realiza no sentido de reafirmar a participação dos sujeitos, de forma ativa e responsável, observando as leis e regras coletivas como resultantes de um debate público sob responsabilidade do cidadão (AUDIGIER, 2016, p. 27). Assim, na consciência cidadã, a consciência política se faz em ato, como prática social.

Nosso intuito, neste texto, está circunscrito à análise de uma questão específica sobre o que os jovens que participaram da pesquisa Jovens e a História, no MERCOSUL, indicam como conteúdo que vem sendo desenvolvido nas aulas de História.

A relevância dessa questão para pensar a relação entre ensino de História e cidadania situa-se na observação de que os conteúdos históricos ensinados sem uma intencionalidade, que implique o desenvolvimento de uma consciência cidadã e política, podem resultar na incapacidade de compreensão crítica do tempo vivido. Compreensão crítica que estamos entendendo como o desenvolvimento da capacidade de analisar os acontecimentos históricos no decurso do tempo e nele intervir para transformar a realidade.

Convém destacar que, ao pensarmos na intencionalidade histórica, considera-se que o Ensino de História não é um campo em que a neutralidade seja possível. Como indica Laville (2005, p. 28),

No presente durante os últimos vinte anos, notaram-se, em quase toda parte do mundo, várias tentativas de controle da memória, particularmente a que se constrói no meio escolar, mesmo que os programas declarem ter outros objetivos. Nessas tentativas, tratase de colocar o conteúdo histórico do ensino de história a serviço de uma nova ordem, ou simplesmente preservar a ordem vigente. Em todo caso, o que está em jogo é a imposição de uma dada narrativa histórica e, através dela, a inserção nas consciências de uma determinada memória.

O afirmado pelo autor permite inferir que uma compreensão crítica da História implica em considerar a diversidade de narrativas que compõem a memória humana. O que defendemos é a não imposição de uma narrativa histórica em detrimento de outras, mas o direito dos jovens estudantes terem acesso à multiplicidade de narrativas históricas para que possam se 
posicionar politicamente diante do conhecimento que possuem. Contudo, se restringirmos o conhecimento histórico dos jovens às narrativas que interessem a um grupo social em detrimento de outros, impossibilitamos o direito ao conhecimento histórico e, ao mesmo tempo, negamos o direito à memória e à história dos que historicamente foram silenciados por processos de colonização, que não se restringem ao espaço geográfico, mas se reproduzem nas formas de ser, viver e pensar dos sujeitos.

Ao conhecer narrativas históricas dos diferentes grupos sociais, os sujeitos têm a possibilidade de se reconhecer e identificar-se com a história de seus antecessores. Esta relação de identificação parece essencial para o desenvolvimento de uma consciência cidadã.

Audigier (2016) aponta que, para pensar a relação ensino de História e cidadania se faz necessário pensar qual cidadão se deseja formar e, para tanto, há que se pensar qual história escolar temos necessidade. Nesta direção, para pensar qual história temos necessidade, propomo-nos a considerar o que tem sido ensinado, a partir das respostas dos estudantes de Sergipe a uma das questões da pesquisa, desdobrada em oito variáveis, que apresentamos na sequência.

\section{A HISTÓRIA ENSINADA}

Em todas as análises desenvolvidas a partir deste ponto, estaremos usando os dados da amostra aracajuana. Esta amostra é composta de 116 casos, sendo 55 do sexo feminino e 58 do sexo masculino; 87 de escola pública e 29 de escola privada, e as escolas públicas tiveram a seguinte composição: Pública de excelência, 29; Pública Central, 28; Pública de periferia, 30 . Houve apenas uma escola privada na amostra, confessional, com 29 participantes. Em termos de religião, 57,8\% declararam-se católicos; 12,9\% evangélicos; 0,9\% judeus; 10,3\% de outras religiões e 18,1\% sem religião. Em termos de profissão dos pais, pode-se verificar a distribuição na Tabela 1. 
Tabela 1 - Área de trabalho dos pais na amostra do Projeto Jovens e a História na cidade de Aracaju

\section{Questão 11. Qual é a ocupação do membro da família que recebe o maior pagamento?}

\begin{tabular}{|c|c|c|}
\hline & Frequência & $\begin{array}{r}\text { Porcentagem } \\
\text { válida }\end{array}$ \\
\hline Diretor de empresa & 16 & 14,0 \\
\hline Profissão de nível superior & 31 & 27,2 \\
\hline Técnico/profissão de nível médio & 16 & 14,0 \\
\hline Funcionário de escritório & 6 & 5,3 \\
\hline Trabalhador no comércio/mercados & 15 & 13,2 \\
\hline Operário na indústria ou construção & 8 & 7,0 \\
\hline Operador de máquinas/motorista & 8 & 7,0 \\
\hline Trabalhador não qualificado & 4 & 3,5 \\
\hline Militar/policial & 10 & 8,8 \\
\hline Total & 114 & 100,0 \\
\hline \multicolumn{3}{|l|}{ Valores ausentes } \\
\hline Não respondeu & 1 & \\
\hline Erro de preenchimento & 1 & \\
\hline Total & 2 & \\
\hline Total & 116 & \\
\hline
\end{tabular}

Fonte: Dados do Projeto Jovens e a História (2013). Organização da autora.

Aracaju é a capital do Estado de Sergipe e, em 2016, sua população era de 641.523 habitantes, segundo o IBGE. Seu nome "significa 'cajueiro dos papagaios'. A palavra é composta por dois elementos: 'ará', que significa 'papagaio', e 'acayú', que significa 'fruto do cajueiro'” (ARACAJU, 2017). É uma cidade litorânea, e situa-se entre os rios Sergipe e Vaza-Barris, com extensão aproximada a 181,8 quilômetros quadrados. Sua existência como capital de Sergipe completou 162 anos em 2017, pois substituiu a antiga capital, considerada a $4^{\mathrm{a}}$ cidade mais antiga do Brasil, São Cristóvão, que é um dos municípios limítrofes de Aracaju. A maior parte de seu território é de planície flúvio-marinha e planície marinha. A temperatura média anual é de $26^{\circ} \mathrm{C}$ (ARACAJU, 2017). 
Sua criação, em meados do século XX, justificou-se pela perspectiva do desenvolvimento do Estado, através da criação de um porto que comportasse o escoamento da produção canavieira da região mais produtiva da província. Além desse fator, que foi fundamental para sua criação, Aracaju é criada como cidade-capital seguindo o pensamento de uma "racionalidade técnica e utópica, de uma nova maneira de entender as cidades e de operar sobre espaços, herdada, sobretudo do pensamento Europeu" (SANTOS, 2007, p. 64).

Aracaju foi planejada pelo engenheiro Sebastião José Basílio Pirro, e teve a colaboração de Francisco Pereira da Silva. Conforme Santos (2007, p. 64), "a cidade foi traçada em estrutura urbana ortogonal bem simplificada: 32 quadras simétricas", e os lotes que compunham as quadras não tiveram seu tamanho dividido de forma homogênea. O traçado que lembra um tabuleiro de xadrez: a partir de um planejamento inicial, implicou em um esforço muito grande no sentido de alterar a topografia do terreno para efetivar o planejado. A criação da cidade-capital Aracaju implicou, portanto, em alterações relativas à natureza, bem como em refundar a história pela negação simbólica de seu passado fundante (SANTOS, 2007).

Negação de um passado que não se restringe somente à questão de alteração da capital, mas se faz presente através de alguns silenciamentos, principalmente em relação à questão indígena e à questão afro-brasileira. São recentes as pesquisas que abordam essas temáticas, e praticamente não se estuda a história e cultura indígena e afro-brasileira nas escolas que temos tido acesso, apesar da legislação pertinente prever a obrigatoriedade do ensino de história e cultura afro-brasileira e indígena em todos os níveis de ensino, desde 2003 e 2008, conforme estabelecido pelas leis 10.639/2003 (BRASIL, 2003) e 11.645/2008 (BRASIL, 2008).

Em uma sociedade em que ao passado direcionam-se silenciamentos seletivos, principalmente em relação às narrativas dos grupos originários, entendemos que é importante e necessário que o Ensino de História se efetive na direção de possibilitar que essas memórias e histórias sejam dadas a conhecer, porque nos constituem no que nos tornamos. Compreender o passado implica em, no mínimo, diminuir os silenciamentos e possibilitar 
que as vozes silenciadas falem. Para tanto, a intencionalidade histórica se faz necessária e é condição para fazer justiça, no sentido de restituir o direito à memória e à história aos sujeitos cuja existência sofre de um apagamento produzido pelo silenciamento de suas narrativas.

Na pesquisa Jovens e História no Mercosul, uma das 43 questões respondidas pelos jovens solicitava que eles indicassem: Em que suas aulas de história mais se concentram. Para responder a esta questão, foram disponibilizadas 5 alternativas de resposta: Nunca, Quase nunca, Às vezes, Frequentemente e Quase sempre.

As alternativas oferecidas para serem assinaladas quanto à sua ocorrência foram: Buscamos conhecer os principais fatos da História; Julgamos os principais acontecimentos da História a partir do ponto de vista dos direitos humanos; Tentamos entender como era a vida no passado levando em consideração todos os pontos de vista; Tentamos compreender o comportamento das pessoas do passado considerando o seu; Usamos a História para compreender a situação do mundo atual e descobrir as tendências de mudança; Estudamos de uma forma interessante e que incentiva nossa imaginação; Aprendemos as tradições, características, valores e a missão de nossa nação e de nossa sociedade; Aprendemos a valorizar os lugares históricos e as construções antigas.

Ao observar as questões propostas e pretender analisar as relações entre ensino de História e cidadania, nos ocorre que é necessário considerar que o ensinado é elemento essencial na formação dos sujeitos para o exercício da cidadania; ou seja, no ensinado podemos refletir sobre a intencionalidade do ensino de História.

A questão que selecionamos para pensar a intencionalidade da História ensinada é Em que suas aulas de história mais se concentram. A resposta a esta questão implicou em responder oito afirmativas, segundo a frequência em que ocorrem na visão do estudante. Isto implica, é importante destacar, que não temos elementos para saber se os objetivos ou práticas em sala de aula efetivamente acontecem e como acontecem. O que temos, nos resultados abaixo, são as percepções e representações dos estudantes.

A primeira alternativa a ser respondida remete à temática da História como estudo de fatos do passado: Buscamos conhecer os principais fatos da 
História. Nesta questão obtivemos as seguintes respostas: Nunca, 0,89\%; Quase nunca, 1,79\%; Às vezes, 11,71\%; Frequentemente, 32,29\%; Quase Sempre, $46,43 \%$. A menor porcentagem foi $0,89 \%$ para Nunca; e a maior, 46,43\% para Quase sempre. Observa-se uma predominância significativa da prática do ensino da História como uma prática de conhecimento dos fatos. Certamente, compete ao ensino de História dar a conhecer os fatos históricos. Contudo, isto denota que ainda temos, como prática privilegiada, o fato histórico como elemento central do ensino, o que pode denotar que outros aspectos da formação são pouco contemplados, principalmente se pensarmos na análise do ensinado em relação ao presente, aos direitos humanos e à diversidade de narrativas sobre um mesmo acontecimento. Estes resultados também remetem a outra pergunta: o que os estudantes consideram como principais fatos da História? Na elaboração do questionário, a referência para a construção desta questão foram os acontecimentos canônicos que marcaram a História ocidental, por entendermos que ainda persiste um ensino de História, cujos marcos temporais se fundam no quadripartite francês e permanecem como orientadores dos conteúdos ensinados em História. Também como o fato de que a cronologia continua presente na organização do livro didático de História, tanto nos anos finais do Ensino Fundamental como no Ensino Médio.

A segunda variável respondida refere-se ao tratamento em relação aos conteúdos históricos. Julgamos os principais acontecimentos da História a partir do ponto de vista dos direitos humanos. As respostas foram: Nunca, 6,19\%; Quase nunca, 12,39\%; Às vezes, 49,56\%; Frequentemente, 25,66\%; Quase sempre, 6,19\%. Nunca, quase nunca e às vezes somam 68,14\%, indicando que o aspecto dos direitos humanos é pouco considerado no ensino da História ou na percepção que os alunos apresentam sobre o ensinado. Estes dados remetem a considerar que a ênfase dos fatos históricos ensinados somente às vezes recai sobre a perspectiva dos direitos humanos, denotando pouca ênfase para esse objetivo em relação aos demais. Este dado reporta a questionar: para que ensinamos história? Se nossa intenção está na formação da cidadania, seria possível efetivar essa formação se não consideramos a História do ponto de vista dos direitos humanos? 
A terceira questão remete a diferentes perspectivas sobre os conteúdos históricos: Tentamos entender como era a vida no passado levando em consideração todos os pontos de vista. Como respostas, obtivemos: Nunca, 1,77\%; Quase nunca, 3,54\%; Às vezes, 15,04\%; Frequentemente, 38,05\%; Quase sempre, 41,59\%. As respostas obtidas indicam que, da perspectiva dos estudantes, são considerados os diferentes pontos de vista, quase sempre e frequentemente. Mesmo que não consigamos precisar quantos e quais são os pontos de vista, fica perceptível que, ao ensinar História, há uma preocupação em que se evidenciem diferentes perspectivas históricas.

Uma quarta questão remete às relações possibilitadas ou não entre o passado e o presente, bem como permite perceber se relações de pertencimento histórico são ou não possibilitadas. Tentamos compreender o comportamento das pessoas do passado levando em conta o pensamento deles na época em que viveram. Nunca obteve 4,39\% das respostas; Quase nunca, 10,08\%; Às vezes, 27,76\%; Frequentemente, 35,73\%; e Quase sempre, 22,05\%. As respostas demonstram que os alunos, frequentemente e quase sempre, correspondendo a 57,78\%, percebem que há um esforço para que seja possível estabelecer relações entre o passado vivido por nossos antecessores e o presente, considerando a distância temporal que nos afasta. Embora o percentual dos que nunca, quase nunca e às vezes, não estabeleça relações do comportamento das pessoas, levando em conta o pensamento deles na época em que viveram, seja alto, pode denotar a dificuldade em estabelecer a necessária diferenciação temporal entre passado e presente, com vistas a evitar interpretações anacrônicas do comportamento das pessoas e grupos humanos que nos antecederam.

A quinta afirmativa refere-se à característica de compreender o presente a partir do passado e projetar o futuro, perguntando a frequência pela qual os estudantes percebem a seguinte prática: Usamos a história para compreender a situação do mundo atual e descobrir as tendências de mudança. As respostas foram: Nunca, 0,93\%; Quase nunca, 10,19\%; Às vezes, 31,48\%; Frequentemente, 38,89\%; e Quase sempre, 18,52\%. Entende-se que as respostas mais recorrentes indicam que nem sempre os jovens aracajuanos percebem que a História ensinada possibilita que compreendam a História 
como um processo que não se encerra no passado. Neste sentido, a formação histórica ficaria fragilizada, se considerarmos que, para tanto, precisamos nos compreender como sujeitos inseridos em uma historicidade, no presente, entrelaçado no passado, mas que projeta um futuro.

A sexta pergunta aproxima-se da questão metodológica do ensino, questionando: Estudamos de uma forma interessante e que incentiva nossa imaginação? As respostas obtidas foram: Nunca, 5,50\%; Quase nunca, 16,51\%; Às vezes, 34,86\%; Frequentemente, 23,85\%; e Quase sempre, 19,27\%. Neste item é interessante observar que a alternativa às vezes se destaca. Possivelmente este indicador se remeta ao que os jovens consideram uma forma interessante. Estudos têm evidenciado que o uso de filmes, imagens, jogos e redes sociais, entre outros, têm impactado as aulas, tornando-as mais interessantes aos olhos de seus públicos.

A sétima questão direciona-se para o caráter nacionalista da História ensinada, e pergunta: Aprendemos as tradições, características, valores e a missão de nossa nação e de nossa sociedade? Como resposta, encontramos: Nunca, 4,46\%; Quase nunca, 12,50\%; Às vezes, 31,25\%; Frequentemente, $33,04 \%$; e Quase sempre, 18,75\%. Estes índices indicam que, em muitas situações, as aulas de História estão sendo consideradas como aprendizagem das tradições, das características, dos valores e da missão de nossa nação e nossa sociedade. Neste sentido, parece que o ensinado se aproxima de uma História que prioriza o caráter de formação de uma identidade nacional. Neste aspecto, questionamos: que identidade seria essa? Qual a identificação possível de nosso país? Questões que serão abordadas em outra pesquisa, mas que já se anunciam como importantes para compreender como os jovens constroem sua identidade nacional.

Uma última afirmativa para a questão remete a pensar como o ensino de História atua em relação ao patrimônio, e propõe: Aprendemos a valorizar os lugares históricos e as construções antigas? As respostas foram: Quase nunca, 10,09\%; Às vezes, 28,44\%; Frequentemente, 26,21\%; e Quase sempre, $34,86 \%$. Chama a atenção, nestas respostas, o baixo índice para quase nunca. E qual é o lugar do patrimônio no Ensino de História? O que estamos entendendo por patrimônio histórico? Embora o quase sempre seja o 
mais alto, entendemos que o trabalho com patrimônio material e imaterial é um importante e necessário âmbito de trabalho para o desenvolvimento de uma consciência histórica.

Na figura 1, baseada nas médias das respostas dos estudantes, é possível vislumbrar a hierarquia que se estabelece entre os objetivos propostos no instrumento de pesquisa. Apesar de algumas diferenças pontuais nas médias nacional e local, é possível notar que esta hierarquia praticamente não sofre modificações. O objetivo percebido como mais constante é o trabalho da História com os fatos, seguido do entendimento da vida no passado a partir de diferentes pontos de vista; da compreensão do comportamento das pessoas, de acordo com seu tempo histórico e da valorização dos vestígios históricos e das construções antigas. Como um quinto objetivo, por ordem decrescente de constância, é o que remete a usar a História para compreender a situação do mundo atual e descobrir tendências de mudanças. O objetivo menos constante na percepção dos estudantes é o de julgar os acontecimentos do ponto de vista dos direitos humanos, destacando o fato de que o percentual se mantém menor em relação à média nacional, seguido em ordem crescente pelo estudo da História de maneira interessante e que estimula a imaginação. Em seguida, aparece como menos constante aprender as tradições, características, valores e a missão da nação e da sociedade.

Importa observar, ainda, que entre os resultados referentes à média nacional e aracajuana, a tendência se mantém ao longo das questões indicadas. Contudo, o maior destaque que evidencia uma diferença significativa em relação à média nacional situa-se na valorização dos vestígios e construções antigas. Relação que pode ser estabelecida com o trabalho da História com os fatos. A tendência dos resultados da questão $6 \mathrm{a}$ e $6 \mathrm{~h}$, em relação à média nacional, pode indicar a percepção dos jovens para a compreensão da história monumento, que enfatiza os fatos e os monumentos em detrimento de uma história vista de baixo, que considere as diferentes narrativas históricas sobre o passado.

Acompanhando a média nacional, o percebido pelos jovens aracajuanos em relação ao julgamento dos principais acontecimentos da História, a 
partir do ponto de vista dos direitos humanos, parece que os índices apontam para um caráter quase insignificante em relação à percepção que eles possuem sobre os direitos humanos. Considerando que a história, mesmo em uma abordagem factualista, é repleta de situações que mereceriam uma análise em relação aos direitos humanos, principalmente pelos genocídios cometidos, ocorre perguntar se conteúdos que implicaram no desrespeito à vida são ensinados na perspectiva da violação dos direitos humanos, ou se eles simplesmente figuram como fatos do passado. Sem estabelecer uma relação que questione os genocídios e crimes contra a humanidade cometidos no passado, possivelmente esses conteúdos não mobilizem os sujeitos no desenvolvimento de uma consciência política e cidadã.

Figura 1 - Comparação das médias* nacional e de Aracaju das respostas dos estudantes à questão 6 do instrumento de coleta de dados

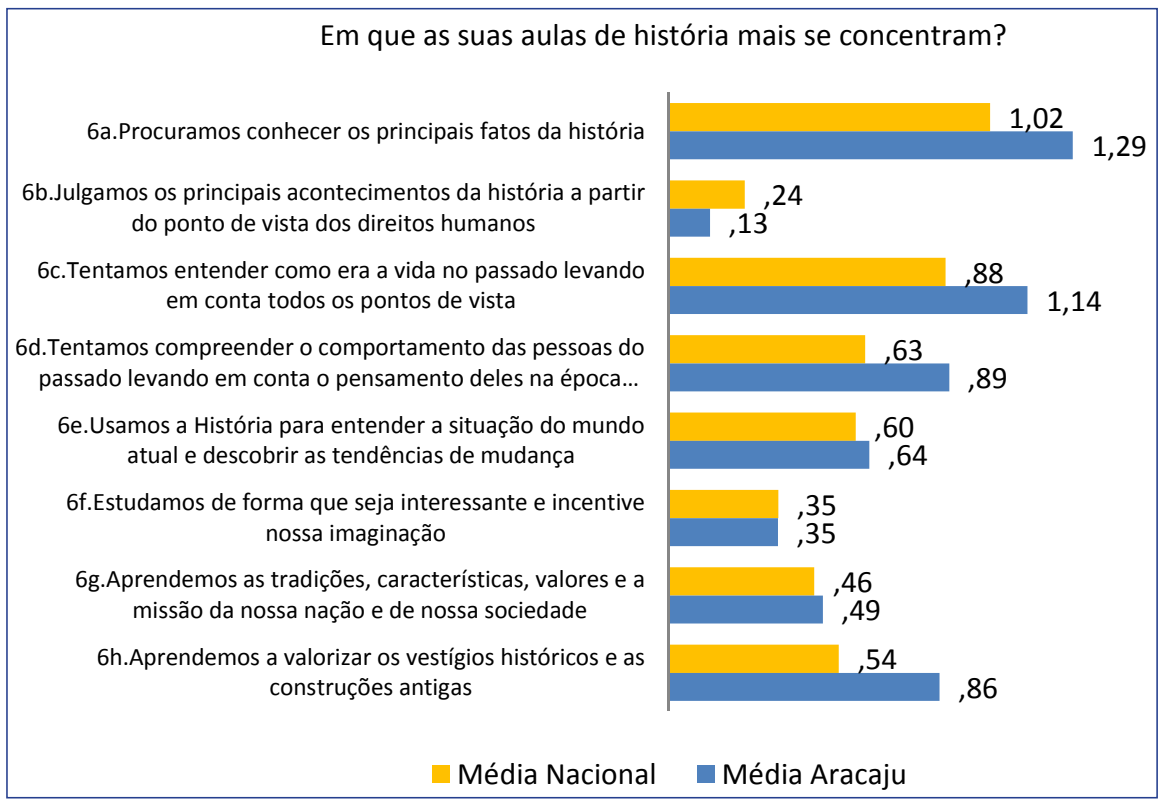

Fonte: Projeto Jovens e a História (2013). Elaboração da autora.

* Médias aritméticas das respostas obtidas pela transformação da escala Likert na seguinte escala numérica: nunca $=-2$; quase nunca $=-1$; às vezes $=0$; frequentemente $=$ 1 ; quase sempre $=2$.

Parece pertinente inferir que, nas aulas de História, para esse grupo de jovens, quase sempre buscam conhecer os principais fatos da História, às 
vezes julgam os principais acontecimentos da História a partir do ponto de vista dos direitos humanos; quase sempre tentam entender como era a vida no passado, levando em consideração todos os pontos de vista; frequentemente tentam compreender o comportamento das pessoas do passado considerando o seu; frequentemente usam a História para compreender a situação do mundo atual e descobrir as tendências de mudança; às vezes estudam de uma forma interessante e que incentiva a imaginação; frequentemente aprendem as tradições, características, valores e a missão de nossa nação e de nossa sociedade; e quase sempre aprendem a valorizar os lugares históricos e as construções antigas.

Também foi perguntado aos participantes sobre sua participação política. Esclarecemos que se entende participação por grêmio estudantil, campanhas políticas, ambientais, partidos políticos, associação de moradores, movimentos sociais, etc. Foram separadas três categorias de estudantes por participação, conforme se verifica na figura 2, em que são desagregadas as afirmações em foco pela participação política declarada pelos respondentes.

Figura 2 - Comparação das médias* das respostas de estudantes de Aracaju à questão 6 do instrumento de coleta de dados, desagregado por categoria de participação política declarada

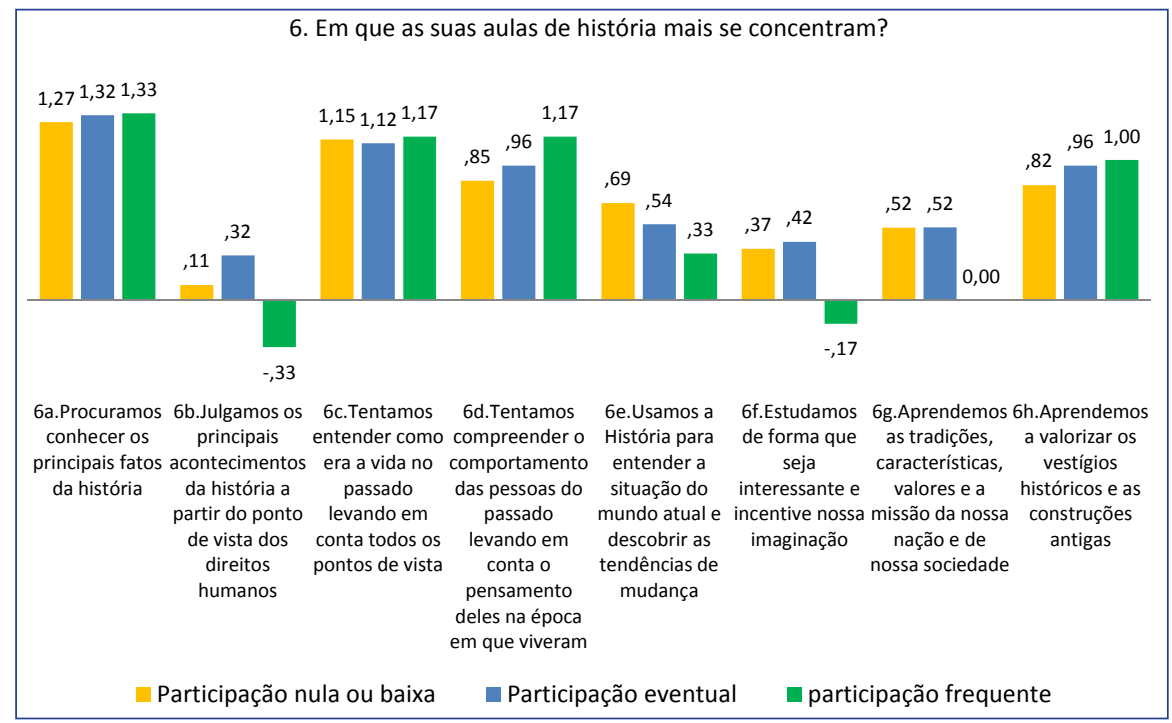

Fonte: Projeto Jovens e a História (2013). Elaboração da autora.

* Médias aritméticas das respostas obtidas pela transformação da escala Likert na seguinte escala numérica: nunca $=-2$; quase nunca $=-1$; às vezes 70 ; frequentemente $=1$; quase sempre $=2$. 
Pode-se notar que, em algumas das afirmativas que compõem a questão, praticamente não há variação, o que indica que a representação não sofre interferência da experiência de participação política, nesses casos. Entretanto, pode-se observar que os estudantes que declaram maior participação política são progressivamente mais céticos ou pessimistas quanto a alguns objetivos perseguidos em sala de aula, na razão direta de sua participação política: quanto a julgar os acontecimentos do ponto de vista dos direitos humanos, uso da História para entender a situação atual, estudar de forma interessante e estimulante e aprender sobre os aspectos da nação e da sociedade. Por outro lado, a participação política está em proporção direta ao reconhecimento do objetivo de compreender as pessoas do passado, levando em conta o pensamento deles na época em que viveram. Relação que implica em um movimento que desloca o sujeito de seu lugar social e tempo histórico para outro lugar social e outro tempo histórico. Movimento que necessita da alteridade como sustentação. Para Rolnik (1992), citada por Zanela (2005, p. 100), alteridade é “[...] o plano das forças e das relações, onde se dá o inelutável encontro dos seres, encontro no qual cada um afeta e é afetado, o que tem por efeito uma instabilização da forma que constitui cada um destes seres, produzindo transformações irreversíveis".

Ao considerar que a relação é direta e proporcional entre reconhecimento do objetivo de compreender as pessoas do passado, levando em conta o pensamento deles na época em que viveram e a participação política, talvez seja necessário pensar que o movimento de se deslocar para o lugar do outro (o outro social e histórico), sem deixar de se ser quem se é, tem implicações no campo dos afetos. Campo ainda pouco explorado pelo Ensino de História, mas que se evidencia como fértil para outras pesquisas que incidam sobre a relação entre ensino de História, alteridade, prática social e formação para a cidadania.

Partindo do que os jovens indicam como o ensinado e do indicado por Audigier (2016) como dimensões em que a intenção do ensino de História se faz presente, observa-se que a intencionalidade do ensino de História atua muito no âmbito da formação da consciência histórica, pouco na formação da consciência política e no campo da formação cidadã. 
Atua no campo da formação histórica ao possibilitar o conhecimento dos principais fatos históricos para compreender o mundo atual e descobrir tendências de mudanças, bem como quando aprendem a valorizar os lugares históricos e as construções antigas e, também, ao compreender o comportamento das pessoas do passado, considerando o seu.

No âmbito da consciência cidadã, situamos as respostas que apontam para o julgamento dos principais acontecimentos da História a partir do ponto de vista dos direitos humanos, para o entendimento da vida no passado, que leva em consideração todos os pontos de vista.

Contudo, se pensarmos na definição de consciência política como a efetivação da consciência cidadã, parece que a História escolar não atua nesse âmbito, pois que se restringe ao campo cognitivo. Conhecer, relacionar, identificar e compreender diferem significativamente de vivenciar ações que possibilitem a efetivação de uma consciência política e cidadã, considerando que a cidadania implica, como dito anteriormente, na participação dos sujeitos, de forma ativa e responsável, observando as leis e regras coletivas como resultantes de um debate público sob responsabilidade do cidadão. Cidadania que seja "integrada por pessoas que pensem, que sintam e que atuem, ou seja, que sejam capazes de pensar para atuar, de sentir para atuar e de atuar para transformar e levar à prática suas ideias, projetos, expectativas, esperanças e utopias" (MIRANDA; BLANCH, 2013, p. 78).

Diante do exposto, acreditamos que o Ensino de História, quando mobilizado em uma perspectiva unicamente reservada ao campo do conhecer cognoscente, não possibilita que os jovens experienciem a consciência política e cidadã, pois permanecem alguns condicionantes próprios da História como ciência. Ciência que, para advogar esse caráter, reivindica uma neutralidade que lhe possibilite a objetividade.

A reivindicação da neutralidade da ciência não mais encontra ressonância, se consideramos que os instrumentos com os quais a ciência trabalha diferem significativamente da proposição de formação cidadã. Esta última necessita, além dos conhecimentos históricos, uma educação cívica. Entre a história ciência e a educação para a cidadania, situa-se, portanto, uma primeira fissura que, antes de ser admitida qualquer incompatibilidade, 
precisa de uma desmistificação da História como $a$ história. Não se trata de negar o caráter de ciência à História, mas de considerar que são muitas as histórias narradas, assim como é diverso o conceito de cidadania. Portanto, a primeira fissura dentre as três indicadas por Audigier (2016) situa-se entre o ensino de História resultante da ciência de referência, a História e a formação cívica necessária ao desenvolvimento da cidadania. Uma segunda fissura é apontada pelo autor como o que se espera do ensino de História e da cidadania. Nas palavras do autor, "a história desenvolve o imaginário, um sentimento de pertencer, uma identidade coletiva, capacidades para pensar num 'nós', relações entre nós e os outros" (AUDIGIER, 2016, p. 33). Entende o autor que estes aspectos são constitutivos da cidadania, mas, além deles, também se esperam comportamentos e ações condizentes com a "comunidade política de pertencimento" (AUDIGIER, 2016, p. 33). A fissura está, portanto, entre o que se transmite como conhecimento e o que se efetiva como experiência, considerando que cidadania implica ação.

Neste sentido, parece apropriado enfatizar que, no modelo escolar que predomina no cenário educacional, não temos considerado a experiência como elemento de formação, o que impede que a cidadania se efetive como consciência cidadã, pois, para tanto, ela necessita efetivar-se como prática social. A terceira fissura apontada por Audigier (2016, p. 33) situa-se no fato de que a História tem como objeto o passado, e a cidadania "enfrenta o mundo atual e seu futuro, um mundo constantemente em movimento".

Contudo, o autor, ao apontar as fissuras, também leva a considerar que elas não se constituem em campos irreconciliáveis, pois, para ele, "história é educação de cidadania e política", porque "a história não poderia englobar toda a educação de cidadania e política e esta última não poderia se reduzir à história" (AUDIGIER, 2016, p. 34).

Ainda na esteira do pensamento de Audigier (2016), convém alertar para o fato de que, para o desenvolvimento de uma consciência cidadã, de uma consciência política e de uma consciência histórica, atue-se a partir da primeira, ou seja, a complementaridade entre história, política e cidadania necessita de um projeto de cidadania que entendemos como definidor da História a ser ensinada. A sociedade pretendida, portanto, pode ser 
a orientação necessária para que a História ensinada atue no âmbito de uma consciência política e cidadã. Consciência que necessita considerar as mudanças de "imaginários coletivos, as referências identitárias, os sentimentos de pertencimentos" (AUDIGIER, 2016, p. 37).

\section{CONSIDERAÇÕES FINAIS}

Ao pretendermos refletir sobre o Ensino de História e cidadania, intencionamos problematizar uma relação que frequentemente é tomada como evidente, mas que, na sua efetivação, nem sempre atinge o que se propõe.

A relação entre cidadania e ensino de História implica em uma formação histórica que se compõe a partir de uma relação entre consciência histórica, consciência cidadã e consciência política.

Consciência que parece não se efetivar a partir da história ensinada, pois, como indicado a partir da questão analisada sobre o ensinado, há um enfoque para os conteúdos históricos, cuja intencionalidade centra-se no conhecimento escolar, não observando investimento no campo da ação.

Ficou evidenciado, a partir das contribuições de François Audigier que, para que a relação ensino de História e cidadania se efetive, a consciência cidadã pode definir um projeto de sociedade para o qual o conhecimento histórico assume importância fundamental, pois possibilita aos jovens conhecerem as experiências humanas vividas em outros tempos e outros espaços.

Concluímos que a História escolar necessita considerar que a cidadania assume diferentes configurações, mas não prescinde das ações efetivas para se tornar consciência cidadã alicerçada na consciência política, principalmente diante da diversidade que compõe nossa sociedade. Diversidade que a História nem sempre contempla, mantendo-se, ainda, em uma lógica expositiva cronológica, na maioria dos sistemas escolares, como fica evidente na pesquisa que motivou a reflexão apresentada neste texto.

O ensino de História escolar, ao manter-se na lógica da cronologia, não contribui para o desenvolvimento da consciência cidadã e política, 
pois a cidadania e a política constituem-se em campos que necessitam do presente para se constituir. Isto remete a pensar que ensinar História precisa de referências que considerem o tempo vivido como o horizonte sob o qual se orienta um projeto de sociedade. Como indica Audigier (2016), o ensino de história apresenta três direções para atuar na formação do cidadão, quais sejam: a capacidade de historicizar nossas experiências; a capacidade de situar todo o fenômeno humano e social em sua historicidade; a construção de conceitos que possibilitem analisar uma sociedade e a ação humana no tempo.

Portanto, o ensino de História tem um papel fundamental na formação de um cidadão que compreenda o tempo em que vive. Compreensão que nem sempre passa pela escola, mas que tem se efetivado em experiências cidadãs, como a indicada por Ana Júlia, na epígrafe inicial deste texto.

Talvez possamos aprender, com os movimentos sociais, a mobilizar a História para o desencadeamento de ações cidadãs. Uma história que não se limita à lógica expositiva e cronológica, que não se contrapõe à ação, mas a toma como elemento de formação.

\section{REFERÊNCIAS}

ARACAJU. História. 2017. Disponível em: <http://www.aracaju.se.gov.br/ aracaju/historia> Acesso em: 28/06/2018.

ARACAJU. Aspectos Geográficos. 2017. Disponível em: <http://www.aracaju. se.gov.br/aracaju/aspectos_geograficos> Acesso em: 28/06/2018.

AUDIGIER, François. História escolar, formação da cidadania e pesquisas didáticas. In: GUIMARÃES, Selva (org.). Ensino de História e cidadania. Campinas, SP: Papirus, 2016.

BRASIL. Ministério da Educação. Lei n. 10.639 de 09 de Janeiro de 2003. Altera a Lei no 9.394, de 20 de dezembro de 1996, que estabelece as diretrizes e bases da educação nacional, para incluir no currículo oficial da Rede de Ensino a obrigatoriedade da temática "História e Cultura AfroBrasileira”, e dá outras providências. Diário Oficial da União, Brasília, DF, 10 jan. 2003. P. 1. 
BRASIL. Ministério da Educação. Lei n. 11.645 de 10 de Março de 2008. Altera a Lei 9.394, de 20 de dezembro de 1996, modificada pela Lei 10.639, de 9 de janeiro de 2003, que estabelece as diretrizes e bases da educação nacional, para incluir no currículo oficial da rede de ensino a obrigatoriedade da temática "História e Cultura Afro-Brasileira e Indígena". Diário Oficial da União, Brasília, DF, 11 mar. 2008. P. 1.

CERRI, Luís F. Ensino de História e consciência histórica: implicações didáticas de uma discussão contemporânea. São Paulo: FGV, 2011.

FIORI, Ernani Maria. Aprender a dizer a palavra. In: FREIRE, Paulo. Pedagogia do Oprimido. 29 ed. Rio de Janeiro: Paz e Terra, 1987.

FREIRE, Paulo. SHOR, Ira. Medo e ousadia: o cotidiano do professor. Rio de Janeiro: Paz e Terra, 1986.

FREIRE, Paulo. Conscientização - Teoria e Prática da Libertação: Uma Introdução ao Pensamento de Paulo Freire. São Paulo: Editora Cortez \& Moraes, 1979.

MIRANDA, Sônia R.; BLANCH, Joan P. Cidade, Memória e Educação: conceitos para provocar sentidos no vivido. In: MIRANDA, Sônia R.; SIMAN, Lana M. C. (orgs.). Cidade, memória e educação. Juiz de Fora-MG: Editora UFJF, 2013, p. 59-92.

SANTOS, Waldefrankly Rolim de A. Práticas e apropriações do urbano na cidade de Aracaju/SE. Dissertação de Mestrado. Núcleo de Pós-graduação em Desenvolvimento e Meio Ambiente/UFS. São Cristóvão, 2007, 144fls.

ZANELLA, Andréa V. Sujeito e alteridade: reflexões a partir da psicologia histórico-cultural. Psicologia \& Sociedade; 17 (2): 99-104; mai/ago, 2005. Acesso em: 18 ago. 2017. Disponível em: <http://www.scielo.br/pdf/psoc/ v17n2/27049.pdf/\%3E> 


\section{SENTIDOS DA HISTÓRIA ATRIBUÍDOS POR JOVENS EM DIÁLOGO COM ASPECTOS DE UMA CULTURA POLÍTICA E HISTÓRICA EMERGENTES NA CULTURA ESCOLAR}

Lana M. de C. Siman

Herbert de Oliveira Timóteo

João Andrade

Mariano A. Diniz Filho

\section{UM INÍCIO DE CONVERSA...}

Apreender e analisar a formação dos sentidos da História atribuídos por diferentes jovens ${ }^{1}$ estudantes do primeiro ano do Ensino $\mathrm{Médio}^{2}$, na cidade de Belo Horizonte, pode remeter a variados campos epistemológicos e de pesquisas nas áreas da sociologia, antropologia, filosofia, entre outras. São processos complexos, por vezes, implicados em relações históricas mais amplas, pois que ancoradas nos tempos (HELLER, 1993). E quando se trata de apreendê-los e analisá-los, durante processos do ensinar e aprender História em variados ambientes educativos, outros dialogam com aspectos da cognição e sensibilidades (MIRANDA, 2007; PEREIRA; SIMAN, 2009). Movimentos estes envolvidos em variadas potencialidades, contradições e reveses.

Para a apreensão e análise da formação dos sentidos históricos, supostamente construídos pelos alunos do primeiro ano do Ensino Médio que responderam aos questionários do projeto Os Jovens e a História em março de 2013, tomamos como referência Rüsen (2001; 2010; 2014). Não obstante, neste movimento, comparecem outras experiências vivenciadas pelos jovens estudantes, no caso, as práticas culturais (PEREIRA; SIMAN, 2009), construídas nos âmbitos de uma cultura escolar (FARIA FILHO; VIDAL, 2004), em diálogos com aspectos de uma cultura histórica (ABREU;

\footnotetext{
${ }^{1}$ Para aprofundamento acerca das reflexões e experiências das juventudes, sugerimos as leituras de Dayrell (2013; 2013). Acesso ao observatório da juventude UFMG: <http://observatoriodajuventude. ufmg.br/> e ao observatório jovem da UFF: <http://www.uff.br/observatoriojovem/>.

${ }^{2}$ Atualmente, no Brasil, esta modalidade educativa experiencia múltiplas tensões e controvérsias advindas de movimentos da Sociedade Civil, Estado, Escola e Universidade. Desta forma, podemos caracterizá-la como uma Questão Socialmente Viva (TUTIAUX-GUILON, 2011).
} 
GONTIJO; SOIHET, 2007), criando predisposições favoráveis para lutas de acesso aos bens materiais e simbólicos, contribuindo para a formação de cultura democrática (MOISES, 1992).

As pesquisas acerca dos processos de atribuição de sentidos à História, pelos jovens estudantes do Ensino Médio, podem estar ancoradas em variadas perspectivas, tanto teóricas quanto metodológicas, mas ainda são poucas. De maneira geral, até o momento, temos Hollerbach (2007) e Diniz Filho (2013). No campo, mais especifico, da consciência histórica, com o qual se relaciona a formação de sentido histórico, objeto deste trabalho, temos outras pesquisas e trabalhos realizados, tanto internacionalmente como nacionalmente, entre eles Pais (1999), Barca (2012), Cerri e Molar (2010), Cerri, (2011b), Cerri e Aguirre (2011) e Schimdt (2016a; 2016b) ${ }^{3}$.

Além de contribuir para essa área de estudos, nosso trabalho visa, também, a trazer contribuições analíticas ao projeto Os Jovens e a História ${ }^{4}$. Assim, vamos analisar os sentidos atribuídos à História dados pelos jovens estudantes do Ensino Médio, em duas escolas públicas, nas quais aplicamos os questionários do projeto em março de 2013.

Do conjunto de cinco escolas de Belo Horizonte onde foram aplicados os questionários do projeto Os Jovens e a História, junto aos alunos e professores de História, duas escolas públicas foram escolhidas. Uma das escolas localiza-se em comunidade de alta vulnerabilidade social, e outra na região centro-sul da cidade. A primeira atende jovens de sua localidade; a outra, os jovens provenientes de diferentes territórios desta cidade e de

\footnotetext{
${ }^{3}$ Conforme pesquisa realizada no portal de dissertações e teses da Capes, até o momento, encontramos as duas dissertações. As outras pesquisas e trabalhos encontrados emergem de nossa pesquisa nos sítios eletrônicos de algumas revistas, no campo do ensino de História, e da Educação, entre elas a História Hoje, e Educação (UFSM), exceto o livro de Pais (1999).

${ }^{4}$ Este Projeto de pesquisa, de natureza predominantemente quantitativa, dialoga com o Youth and History, desenvolvido nos países europeus a partir de 1994, com base na rede European Standing Conference of History Teachers Associations (Euroclio). A partir de 2006, tendo em vista contribuir com a construção sociocultural do MERCOSUL, notadamente pesquisando aspectos da consciência histórica dos jovens desse território, pesquisadores latino-americanos inserem-se nesse projeto, realizando uma adequação e reformulação de algumas perguntas do questionário usado no projeto Youth and History, atentando para nossas especificidades sócio-históricas. No Brasil, ele é coordenado pelo pesquisador Luís F. Cerri (GEDHI/UEPG), realizando trabalho conjunto com outros grupos de pesquisa na área do Ensino e Aprendizagem de História, entre eles LABEPEH/CP/FAE/UFMG e POLISMNEMOSINE/PPGE/FAE/UEMG. Para apreensão e compreensão deste projeto, a partir de suas publicações, sobretudo no Brasil, sugerirmos a leitura de Barom (2016).
} 
seu entorno. Ambas as escolas pertencem à rede estadual de ensino do Estado de Minas Gerais tendo, do ponto de vista oficial, normas, legislação e currículos semelhantes. Além disso, nossa escolha por essas duas escolas ocorreu devido à existência, no interior delas, de práticas culturais, sociais e políticas com o engajamento dos jovens. Em uma delas, tais práticas reverberam na comunidade local.

Tendo em vista nosso estudo, selecionamos algumas questões e opções do questionário da pesquisa que foram aplicadas junto aos estudantes e aos professores de História; realizamos algumas visitas exploratórias àquelas duas escolas; e às suas redes sociais de internet. Movimento este que visa a analisar a atribuição de sentidos à História atribuídos pelos jovens, em diálogo com práticas culturais, reinventando a cultura escolar.

Contemporaneamente, sem negligenciar as contradições de uma Educação massificada, a escola tem, cada vez mais, aberto seus portões e salas de aula a várias práticas culturais (FORQUIM, 2001; SIMAN, 2003). É dentro destes complexos contextos da Educação Básica que vamos buscar analisar os sentidos atribuídos, pelos jovens estudantes, à História.

Importante também é ressaltar que tais processos dialogam com variadas experiências na/da sala de aula, nos espaços da escola, e para além dos seus portões. São práticas culturais nas quais os jovens educandos estão inseridos e/ou são, potencialmente, mobilizados pelos docentes e a escola a se engajarem, oportunizando, por vezes, diálogos com uma cultura histórica, política. O trabalho de Schimdt (2016a), em alguns aspectos, potencializa a realizar inferências nesta direção. Uma delas, reafirmar as potencialidades das práticas culturais quando, em diálogo com a vida prática e as carências de orientação dos jovens alunos, proporciona, por vezes, reflexões, questionamentos ou atitudes acerca de aspectos da cultura histórica. Também, provavelmente, iniciar processos, na perspectiva de reinvenção da categoria política, desde o espaço da sala de aula, oportunizando possíveis atribuições de sentidos à História.

Diante do exposto até aqui, trabalhamos com a suposição de que as práticas culturais possibilitam aos jovens estudantes vivenciarem experiências variadas, que contribuem tanto para a formação de uma cultura política 
de participação democrática ${ }^{5}$, como para agirem de maneira temporalmente orientada. Perguntamos como comparecem a aprendizagem e o ensino da História, assim como a adesão a elementos da cultura histórica difundidos em diferentes lugares e meios, tais como museu, filmes, mídias escritas e digitais, na configuração dos sentidos que os jovens atribuem à História, nesses contextos escolares singulares. Perguntamos, ainda, se há presença de indícios que levam a relacionar os sentidos atribuídos à História pelos jovens com o seu agir no presente, com a sua leitura a respeito do passado e com a elaboração que constroem a respeito do futuro. $\mathrm{O}$ conceito de formação de sentido histórico, construído pelo filósofo da História, Jörn Rüsen, tem uma historicidade e impulsiona ao agir humano (WIKLUND, 2008; CERRI, 2011a). Os processos de formação de sentido histórico perpassam, de maneira geral, os trabalhos daquele filósofo da História, em uma perspectiva para além da dimensão instrumental. A formação de sentido estabelece profundo diálogo com aspectos da Consciência histórica, tendo em vista, sobretudo, a reflexão fundada em bases históricas, visando à tomada de decisões mais elaboradas (CERRI, 2011a).

\section{FORMAÇÃO DO SENTIDO HISTÓRICO...}

Visando a apropriarmo-nos do conceito Sentido histórico de Jörn Rüsen, dialogamos, grossíssimo modo, com seus trabalhos (2001; 2010; 2014), ao mesmo tempo estabelecendo interlocução com outros teóricos que também laçam importantes luzes sobre a formação de sentido histórico.

Se o sentido histórico é construído durante os processos da experiência humana, e está implicado em historicidades (HELER, 1993), de acordo com Jörn Rüsen, ele emerge do pensamento histórico cotidiano, dialogando com aspectos de uma memória histórica, com as temporalidades moventes e processos de formação identitária(s), visando a potenciais orientações e a um engajamento ponderado. Em nosso trabalho, buscamos

\footnotetext{
${ }^{5} \mathrm{O}$ conceito de Cultura Política pode ser trabalhado, complementarmente, através da compreensão de dois cientistas políticos: Moisés (1992) e Borba (2005). Aqui, explicitaremos a apropriação de Julian Borba acerca do trabalho de Almond e Verba (1989), construída no livro The Civic Culture. Para aqueles cientistas políticos, Cultura Política “[...] refere-se às orientações especificamente políticas, às atitudes com respeito ao sistema político, suas diversas partes e o papel dos cidadãos na vida pública" (1989 apud BORBA, 2005, p. 148).
} 
analisá-los enquanto formação que se realiza em diálogo com as práticas culturais experienciadas na cultura escolar, emergentes do diálogo com variados ambientes educativos da cidade. Conforme Rüsen (2001, p. 160), a formação de sentido histórico "[...] perpassa todas as dimensões das mais diversas manifestações da vida humana", entre elas, a sala de aula de história e a escola, em suas dimensões reflexivas, comunicativas e sensíveis (MIRANDA, 2007). Este processo, conforme já escrevemos, demanda diálogos com outros campos.

Tendo em vista apreender e analisar aspectos da experiência histórica que compõem a formação de sentidos históricos, e organizar a reflexão acerca deles, Jörn Rüsen organiza uma tipificação dos mesmos. Para tanto, dialoga com dimensões da memória histórica, relações dinâmicas entre as temporalidades e a formação de identidades. Estas dimensões perpassam um diálogo profundo com a existência humana e buscam, na pesquisa historiográfica, fundamentações para construir uma racionalidade comunicativa. Grossíssimo modo, apresentaremos os tipos de sentido por ele elaborados:

- A constituição tradicional de sentido visa a construir argumentação histórica fundada na representação do establishment do mundo e da vida, negligenciando a produção e o papel crítico da historiografia;

- A constituição exemplar de sentido histórico dialoga com a memória histórica visando a buscar exemplos que orientem o presente. A História é compreendida como mestra da vida, História magistra vitae;

- A constituição crítica de sentido é a tentativa de problematizar os sentidos culturalmente influentes, e oportunizar, recorrendo a dimensões da memória histórica, a busca de modelos alternativos, visando a desnaturalizar a naturalidade aparente;

- A constituição genética de sentido histórico pode ser compreendida como um complexo movimento que considera as várias potencialidades de mudança histórica, em uma 
relação dinâmica com as temporalidades, tendo em vista as complexidades das contingências do presente.

Reiterando, todos estes processos estabelecem uma profunda relação com os questionamentos cotidianos, fundando-se em argumentos historiográficos, visando a formações identitárias e mobilização ao agir reflexivo e, por que não, do sensível. Assim sendo, os sentidos não são encontrados em sua forma pura, mas sendo condicionados, condicionando e problematizando ao mesmo tempo (RÜSEN, 2010). Assim, "a formação de sentido pode ser explicitada conceitualmente como a interconexão complexa de quatro atividades mentais: experimentar, interpretar, orientar e motivar" (RÜSEN, 2014, p. 267). Processos estes potencialmente envolvidos com a elaboração de uma "[...] vontade de agir enquanto força motivadora (RÜSEN, 2014, p. 268, grifos nossos)", tendo em vista, entre outros aspectos, a elaboração de expectativas futuras e a formação identitária. Processo este implicado em potencialidades, limites e contradições.

Diante do exposto, compreendemos ser fundamental atentarmo-nos às múltiplas práticas culturais construídas e experienciadas pelos jovens estudantes do Ensino Médio, sobretudo quando se trata de analisarmos os sentidos, atribuídos por estes jovens alunos, à História. Não obstante, estes processos demandam intercâmbios com outros campos epistemológicos.

\section{DIALOGANDO COM OUTROS CAMPOS...}

Apreender e analisar, dentro do escopo metodológico deste projeto, os sentidos atribuídos à História pelos jovens alunos do primeiro ano do Ensino Médio nas escolas públicas selecionadas, demanda diálogos com aspectos da cultura escolar, histórica, política e as práticas culturais.

Assim, é fundamental dialogarmos com aquilo que se faz entre os muros da escola e dialogar com as normas, fazeres e experiências nas quais vários sujeitos outros estão implicados com aquelas práticas, suas potencialidades, tensões e reveses, ou seja, a cultura escolar (LUCIANO; VIDAL, 2004). Desse fazer entre os muros da escola emergem diálogos com variadas experiências sociais, culturais e políticas experienciadas fora da escola e a partir das contingências nas quais estão inseridos, ou seja, a partir de uma 
cultura histórica (ABREU; GONTIJO; SOIHET, 2007), possibilitando, aos sujeitos, elaborarem sua consciência temporal. Outro conceito fundamental, que possibilita compreender aspectos destes movimentos, é o da cultura política. Na perspectiva do cientista político Jose A. Moisés, há um consenso acerca dele, no qual se envolve "[...] a generalização de um conjunto de valores, orientações e atitudes políticas entre diferentes segmentos em que se divide o mercado político e resulta tanto dos processos de socialização, como da experiência política concreta dos membros da comunidade [...]" (MOISÉS, 1992, p. 7). Todas estas experiências e outros fazeres educativos não estão reduzidos ao espaço escolar, dialogam com outros lugares do entorno da escola e da cidade. Em outras palavras, são aquilo que denominamos como Práticas Culturais e políticas, nas quais estão implicados diversos educadores, no ambiente escolar e não escolar, visando a construir processos de ensinar e aprender, em que as múltiplas dimensões dos sentidos e da cognição são, potencialmente, mobilizadas (SIMAN; MIRANDA, 2011; PEREIRA; SIMAN, 2013). Explicitados nossos conceitos, vamos ao diálogo com nossa metodologia, visando a analisar os sentidos atribuídos à História pelos jovens estudantes do primeiro ano do Ensino Médio.

\section{DIÁLOGOS METODOLÓGICOS...}

A escolha das questões e opções oferecidas por cada uma delas levou em conta a natureza do enquadramento teórico que se está propondo, assim como as reflexões de Cerri (2011b) acerca dos seguintes aspectos: atenção à diversidade de questões dos questionários; as opções são elaboradas usando narrativas, predominantemente, de bases decisionais; o aproveitamento dos dados coletados é feito com softwares de estatística; os processos de formação de sentido histórico podem se realizar no espaço escolar e não escolar; a metodologia quantitativa é apenas uma das abordagens acerca desses processos.

Bom ressaltar que, em nosso caso, trata-se de uma compreensão construída com base em uma análise estatística descritiva ${ }^{6}$. Assim,

\footnotetext{
${ }^{6}$ Acerca desta abordagem, consideramos as reflexões construídas pelo pesquisador Luís F. Cerri, acerca dos usos das estatísticas do projeto Jovens e a História para a construção dos artigos, neste livro, durante o VII Seminário Nacional Didática da História, realizado na Universidade Estadual de Ponta Grossa, no período de 30/11 a 02/12/2016. Referenciamo-nos, também, em Cerri (2011b).
} 
priorizamos, dentro do questionário dos alunos, a atribuição de sentidos à História manifestada por eles na questão 1 (O que significa a história para você?). De outro lado, tendo em vista o aspecto sociocultural da aula (MIRANDA, 2007) e a dimensão relacional, implicada no movimento de formação de sentidos históricos (RÜSEN, 2010), selecionamos a questão 13 (O que normalmente acontece durante as aulas de História?) do questionário dos professores ${ }^{7}$. Em ambas, escolhemos algumas opções que, estatisticamente, evidenciavam uma tendência central, em termos percentuais ${ }^{8}$, mensurados no questionário do projeto, com base na escala Likert $^{9}$, ou escala de atitudes (CERRI, 2011b). Processo este que visa a analisar os sentidos atribuídos pelos jovens educandos à História, no plano nacional e em Belo Horizonte. No caso das análises das escolas públicas, em Belo Horizonte buscamos, dentro do escopo metodológico deste estudo, relacionar os aspectos estatísticos mencionados anteriormente com nossas incursões exploratórias, tanto às escolas quanto às suas redes sociais na internet.

\section{OS DADOS NACIONAIS E DA CIDADE DE BELO HORIZONTE: FORMANDO SENTIDOS HISTÓRICOS}

Tendo em vista as questões apresentadas anteriormente, realizamos o recorte de algumas opções, levando em conta sua tendência central evidenciada pelas porcentagens das alternativas. Com esses dados, analisamos os sentidos atribuídos, por estes sujeitos estudantes, à História, tanto no plano nacional como na cidade de Belo Horizonte. Em seguida, realizamos

\footnotetext{
${ }^{7}$ Conforme sugestões do pesquisador Luís F. Cerri, no decorrer de todo o texto explicitaremos, entre parênteses, para fins de maior clareza, a qual questionário pertence cada uma das questões usadas: Questão 1 (Questionário dos alunos); Questão 13 (Questionário dos professores). Depois, levando em conta aspectos de forma, durante a análise empírica dos dados, tanto da escola pública de periferia quanto da escola pública central, a questão 13 (Questionário dos professores) e suas opções selecionadas para análise terão seus dados apresentados no corpo do texto, sem uso de tabelas.

${ }^{8}$ Escolha realizada após diálogos com o Pesquisador- Coordenador do projeto, tendo em vista, também, nosso estudo. Dados reproduzidos a partir das tabelas (porcentagens válidas) geradas do programa SPSS.

${ }^{9} \mathrm{~A}$ escala de Likert ou escala de atitudes oportuniza, ao respondente, marcar sua concordância ou discordância, graduada em cinco níveis (discordo totalmente, discordo, indiferente, concordo, concordo plenamente), de acordo com as alternativas para cada afirmação do questionário. Essas respostas são traduzidas numericamente, gerando médias e outras sínteses estatísticas que possibilitam visualizar um quadro geral representativo para cada questão.
} 
uma maior verticalização acerca daquele processo nas escolas selecionadas em Belo Horizonte, levando em conta, também, nossas visitas exploratórias.

Desta forma, na questão 1 (Questionário dos alunos), evidenciada na tabela 1, abaixo, em certa medida podemos nos aproximar da percepção do aluno, quanto aos sentidos que atribui à História. Sentidos estes, por vezes, tácitos (PEREIRA, 2003). Podemos observar, as tendências predominantes estão manifestas nas seguintes opções e alternativas, com suas respectivas medidas percentuais: 1f, com a alternativa Mais ou menos obtendo 23,0\%; Concordo, 42,8 \%; e Concordo totalmente, 22,7\%; 1h, Mais ou menos, 25,7\%, Concordo, 40,4\%, Concordo totalmente, 20,7\%; 1b, Mais ou menos, 36,8\%, Concordo, 36,8\%, Concordo totalmente, 10,6\%. Vejamos a tabela 1.

Tabela 1 - Questão 1: O que significa a história para você? (Estudantes do Brasil)

\begin{tabular}{|c|c|c|c|c|c|c|}
\hline & 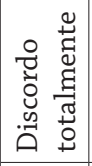 & 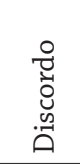 & 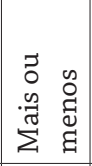 & 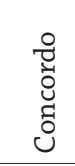 & 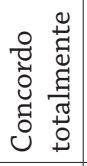 & 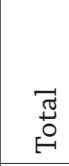 \\
\hline 1a. Uma matéria da escola e nada mais. & 31,4 & 36,4 & 21,3 & 8,1 & 2,8 & 100 \\
\hline $\begin{array}{l}\text { 1b. Uma fonte de coisas interessantes que } \\
\text { estimula minha imaginação. }\end{array}$ & 3,3 & 12,5 & 36,8 & 36,8 & 10,6 & 100 \\
\hline $\begin{array}{l}\text { 1c. Uma possibilidade para aprender com os } \\
\text { erros e acertos dos outros. }\end{array}$ & 6,1 & 16,0 & 34,5 & 33,0 & 10,5 & 100 \\
\hline $\begin{array}{l}\text { 1d. Algo que já morreu e passou e que não tem } \\
\text { nada a ver com a minha vida. }\end{array}$ & 43,1 & 33,8 & 12,7 & 6,6 & 3,8 & 100 \\
\hline $\begin{array}{l}\text { 1e. Um número de exemplos que ensinam o } \\
\text { que é certo e o que é errado, o que é bom e o } \\
\text { que é mau. }\end{array}$ & 9,2 & 24,3 & 40,9 & 21,0 & 4,5 & 100 \\
\hline $\begin{array}{l}\text { 1f. Mostra o que está por trás da maneira } \\
\text { de viver no presente e explica os problemas } \\
\text { atuais. }\end{array}$ & 3,7 & 7,7 & 23,0 & 42,8 & 22,7 & 100 \\
\hline 1g. Um amontoado de crueldades e desgraças. & 29,2 & 37,3 & 23,3 & 7,7 & 2,5 & 100 \\
\hline $\begin{array}{l}\text { 1h. Uma forma de entender a minha vida como } \\
\text { parte das mudanças na história. }\end{array}$ & 4,7 & 8,5 & 25,7 & 40,4 & 20,7 & 100 \\
\hline
\end{tabular}

Fonte: dados do Projeto Jovens e a História (2013). Elaborada pelos autores.

Atentando-nos aos mais de $40 \%$ obtidos no score para as alternativas Concordo nas opções $1 \mathrm{f}$ e $1 \mathrm{~h}$; e os $36,8 \%$ para a mesma alternativa, na opção $1 \mathrm{~b}$, supomos que os jovens estudantes tendem a atribuir um sentido à 
História implicado às tensões, sensibilidades, e por que não continuidades, relacionadas a outras temporalidades, com algum impacto em sua vida cotidiana. Estariam os jovens estudantes brasileiros tendendo a superar o presenteísmo, tal como Hobsbawm (1995) refletiu sobre os jovens? Talvez... Do olhar mais próximo à sensibilidade dos jovens estudantes, vamos à questão 13 (Questionário dos professores). Dito isto, encaminhamos, agora, para aquilo que os professores de História tenderam, estatisticamente, quanto a "o que normalmente acontece durante as aulas de história (grifos nossos)?" Em certa medida, estes aspectos dialogam com o movimento de atribuição de sentidos à História. Observemos, abaixo, os dados, da questão 13 (Questionário dos professores) no plano nacional:

Tabela 2 - Questão 13: O que normalmente acontece em durante as aulas de história?

\begin{tabular}{|c|c|c|c|c|c|c|}
\hline & 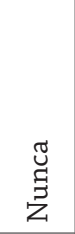 & 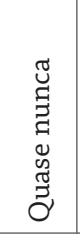 & $\begin{array}{l}\infty \\
\stackrel{N}{N} \\
\infty \\
\infty \\
\infty\end{array}$ & 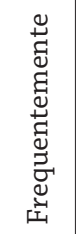 & 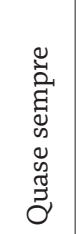 & $\stackrel{\text { ॠే }}{0}$ \\
\hline $\begin{array}{l}\text { 13a. Os estudantes ouvem as minhas exposições } \\
\text { sobre o passado. }\end{array}$ & 0,4 & 1,4 & 21,8 & 48,8 & 27,7 & 100 \\
\hline $\begin{array}{l}\text { 13b. Os alunos são informados do que foi bom ou } \\
\text { mau, certo ou errado na História. }\end{array}$ & 15,7 & 12,9 & 23,2 & 31,8 & 16,4 & 100 \\
\hline $\begin{array}{l}\text { 13c. Eles discutem diferentes explicações sobre o } \\
\text { que aconteceu no passado }\end{array}$ & 0,0 & 4,9 & 36,0 & 42,7 & 16,4 & 100 \\
\hline $\begin{array}{l}\text { 13d. Eles pesquisam diversas fontes históricas: } \\
\text { documentos, fotografias, figuras, mapas. }\end{array}$ & 1,1 & 6,0 & 36,7 & 39,6 & 16,6 & 100 \\
\hline 13e. Eles recordam e reinterpretam a História. & 0,4 & 14,0 & 51,9 & 24,2 & 9,5 & 100 \\
\hline $\begin{array}{l}\text { 13f. Eles ouvem fitas, CD’s ou vemos filmes e vídeos } \\
\text { sobre História. }\end{array}$ & 0,7 & 4,2 & 44,4 & 35,9 & 14,8 & 100 \\
\hline $\begin{array}{l}\text { 13g. Eles usam livros escolares, apostilas ou algum } \\
\text { outro material (fotocópia). }\end{array}$ & 0,0 & 1,8 & 9,5 & 45,6 & 43,1 & 100 \\
\hline $\begin{array}{l}\text { 13h. Eles participam de atividades em grupo: } \\
\text { encenações de teatro, visitas a museus, projetos } \\
\text { com a comunidade. }\end{array}$ & 3,5 & 23,0 & 36,2 & 24,8 & 12,4 & 100 \\
\hline
\end{tabular}

Fonte: dados do Projeto Jovens e a História (2013). Elaborada pelos autores. 
Na questão 13 (Questionário dos professores), escolhemos as seguintes opções, com suas alternativas e medidas percentuais: $13 \mathrm{~g}$, Às vezes (9,5\%), Frequentemente (45,6\%), Quase sempre (43,1\%); 13a, Às vezes (21,8\%), Frequentemente (48,8\%), Quase sempre (27,7\%); e 13c, com Às vezes (36,0\%), Frequentemente (42,7\%), Quase sempre (16,4\%). Não podemos desprezar as tendências percentuais manifestas na alternativa Às vezes, nas opções $13 \mathrm{f}$ e $13 \mathrm{~h}$. Diante destas tendências percentuais manifestas através das opções e alternativas marcadas pelos professores de História, é possível pensar que o uso de textos didáticos diversos, discussões acerca de aspectos do passado e, não menos importante, aspectos das práticas culturais, poderiam potencializar o movimento de atribuição de sentidos à História, pelos jovens educandos.

Pelos dados até aqui analisados, supomos que os jovens estudantes do Ensino Médio tendem a atribuir sentidos críticos e, por vezes, tradicionais à História, pois, conforme Rüsen (2010), diferentes sentidos podem coexistir em um mesmo grupo social. Tendo apresentado, grosso modo, um panorama acerca da atribuição de sentidos à História, pelos jovens alunos no plano nacional, deslocamo-nos a um processo análogo, agora, na cidade de Belo Horizonte.

Em Belo Horizonte, na questão 1 (Questionário dos alunos), apresentada logo abaixo, na tabela 3 , selecionamos as seguintes opções, com suas respectivas tendências percentuais: 1 f, temos as alternativas Mais ou menos (23,7\%), Concordo (50,5\%), e Concordo totalmente (20,4\%); 1 h com Mais ou menos (31,2\%), Concordo (44,1\%), Concordo totalmente (17,2\%); 1b, Mais ou menos (42,4\%), Concordo (43,5\%), Concordo totalmente (7,6\%). Observemos a tabela 3 . 
Tabela 3 - Questão 1 (Questionário dos alunos) - O que significa a História para você?

\begin{tabular}{|c|c|c|c|c|c|c|}
\hline & 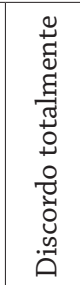 & 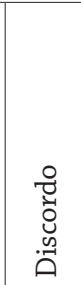 & 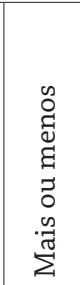 & 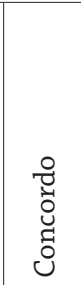 & 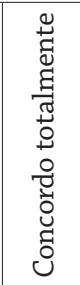 & $\stackrel{\text { त्र }}{0}$ \\
\hline 1a. Uma matéria da escola e nada mais. & 32,3 & 46,2 & 18,3 & 1,1 & 2,2 & 100 \\
\hline $\begin{array}{l}\text { 1b. Uma fonte de coisas interessantes que estimula } \\
\text { minha imaginação. }\end{array}$ & 3,3 & 3,3 & 42,4 & 43,5 & 7,6 & 100 \\
\hline $\begin{array}{l}\text { 1c. Uma possibilidade para aprender com os erros e } \\
\text { acertos dos outros. }\end{array}$ & 5,4 & 16,3 & 35,9 & 29,3 & 13,0 & 100 \\
\hline $\begin{array}{l}\text { 1d. Algo que já morreu e passou e que não tem nada } \\
\text { a ver com a minha vida. }\end{array}$ & 51,6 & 29,0 & 9,7 & 6,5 & 3,2 & 100 \\
\hline $\begin{array}{l}\text { 1e. Um número de exemplos que ensinam o que é } \\
\text { certo e o que é errado, o que é bom e o que é mau. }\end{array}$ & 19,4 & 25,8 & 29,0 & 20,4 & 5,4 & 100 \\
\hline $\begin{array}{l}\text { 1f. Mostra o que está por trás da maneira de viver } \\
\text { no presente e explica os problemas atuais. }\end{array}$ & 2,2 & 3,2 & 23,7 & 50,5 & 20,4 & 100 \\
\hline 1g. Um amontoado de crueldades e desgraças. & 41,8 & 41,8 & 11,0 & 3,3 & 2,2 & 100 \\
\hline $\begin{array}{l}\text { 1h. Uma forma de entender a minha vida como } \\
\text { parte das mudanças na História. }\end{array}$ & 1,1 & 6,5 & 31,2 & 44,1 & 17,2 & 100 \\
\hline
\end{tabular}

Fonte: dados do Projeto Jovens e a História (2013). Elaborada pelos autores.

Arriscaríamos afirmar que podemos pensar que os jovens estudantes tendem a perceber a História a partir de aspectos sensíveis do seu presente, implicados na relação com aspectos de outras temporalidades. Conforme veremos abaixo, na questão 13 (Questionário dos professores), supomos que as práticas culturais, emergentes na/da cultura escolar, potencializem estes processos. A respeito destes movimentos, o que pode informar a questão 13, do questionário dos professores?

$\mathrm{Na}$ questão 13 (Questionário dos professores), escolhemos as seguintes opções, com suas alternativas e tendências percentuais: 13a, Frequentemente (83,3\%), Quase sempre (16,7\%); 13c, com Às vezes (16,7\%), Frequentemente (83,3\%), e 13g, Frequentemente (66,7\%) e Quase sempre (16,7\%). Não obstante, nesta cidade, chamamos atenção para a opção 13h, na qual as alternativas Às vezes e Frequentemente comparecem com 33,3\% e $50 \%$, respectivamente. Observando os dados das opções da questão 13 
(Questionário dos professores), enunciados acima e evidenciados na tabela 4, abaixo, pode-se afirmar que aspectos dialógicos, mediados por variados textos didáticos, e dimensões das práticas culturais experienciadas no âmbito da cultura escolar, em Belo Horizonte, comparecem, em alguma medida, com os processos de atribuição de sentidos à História pelos jovens estudantes do primeiro ano do Ensino Médio.

Tabela 4 - Questão 13 (Questionário dos professores) - O que normalmente acontece em durante as aulas de História?

\begin{tabular}{|c|c|c|c|c|c|c|}
\hline & 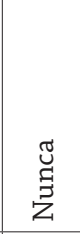 & 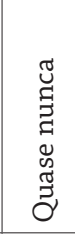 & 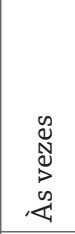 & 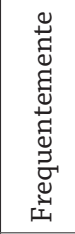 & 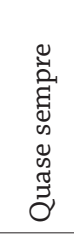 & $\stackrel{\text { तే }}{0}$ \\
\hline $\begin{array}{l}\text { 13a. Os estudantes ouvem as minhas exposições } \\
\text { sobre o passado }\end{array}$ & 0,0 & 0,0 & 0,0 & 83,3 & 16,7 & 100 \\
\hline $\begin{array}{l}\text { 13b. Os alunos são informados do que foi bom ou } \\
\text { mau, certo ou errado na História }\end{array}$ & 33,3 & 33,3 & 0,0 & 16,7 & 16,7 & 100 \\
\hline $\begin{array}{l}\text { 13c. Eles discutem diferentes explicações sobre o } \\
\text { que aconteceu no passado }\end{array}$ & 0,0 & 0,0 & 16,7 & 83,3 & 0,0 & 100 \\
\hline $\begin{array}{l}\text { 13d. Eles pesquisam diversas fontes históricas: } \\
\text { documentos, fotografias, figuras, mapas. }\end{array}$ & 16,7 & 0,0 & 33,3 & 50,0 & 0,0 & 100 \\
\hline 13e. Eles recordam e reinterpretam a História. & 0,0 & 0,0 & 33,3 & 66,7 & 0,0 & 100 \\
\hline $\begin{array}{l}\text { 13f. Eles ouvem fitas, CD's ou vemos filmes e vídeos } \\
\text { sobre História. }\end{array}$ & 16,7 & 0,0 & 50,0 & 33,3 & 0,0 & 100 \\
\hline $\begin{array}{l}\text { 13g. Eles usam livros escolares, apostilas ou algum } \\
\text { outro material (fotocópia) }\end{array}$ & 0,0 & 16,7 & 0,0 & 66,7 & 16,7 & 100 \\
\hline $\begin{array}{l}\text { 13h. Eles participam de atividades em grupo: } \\
\text { encenações de teatro, visitas a museus, projetos } \\
\text { com a comunidade. }\end{array}$ & 0,0 & 16,7 & 33,3 & 50,0 & 0,0 & 100 \\
\hline
\end{tabular}

Fonte: dados do Projeto Jovens e a História (2013). Elaborada pelos autores.

Em Belo Horizonte, realizado este panorama estatístico descritivo quanto aos dados da questão 1 (Questionário dos alunos) e da questão 13 (Questionário dos professores), supomos haver uma razoável tendência à atribuição de sentidos tradicionais e, por vezes, críticos à História, por parte dos jovens alunos.

Vamos, agora, verticalizar estas apreensões e análises, tendo em vista as escolas selecionadas em Belo Horizonte. 


\section{SENTIDOS HISTÓRICOS EM FORMAÇÃO: ESCOLA, JOVENS ESTUDANTES, PROFESSORES DE HISTÓRIA E A CIDADE FAZENDO-SE...}

Vamos analisar mais detidamente, agora, nas escolas selecionadas, os sentidos da História atribuídos por jovens alunos, em diálogo com aspectos de uma cultura política e histórica emergentes na cultura escolar. Para tanto, situamos a escola pública de periferia, a pública central em diálogos com algumas questões e opções do projeto Os Jovens e a História, cotejando com nossas observações exploratórias junto às escolas e suas redes sociais na internet.

A escola pública de periferia ${ }^{10}$ localiza-se em território (SANTOS, 1994) de alta vulnerabilidade social, na região sul da cidade. Esse território é marcado pela pouca presença e atuação do Estado. Nas últimas décadas, devido à atuação de vários movimentos sociais e culturais, essa situação vem se revertendo paulatinamente ${ }^{11}$. Segundo nossas observações exploratórias, mais especificamente acessando as redes sociais da escola em tela, observamos o engajamento ponderado de alguns de seus professores, direção, estudantes e pedagogos junto àqueles movimentos, tendo em vista seu projeto político-pedagógico. Além deste engajamento ponderado, comparecem à sua cultura escolar variadas práticas culturais: teatros; radio web $^{12}$; visita a museus e outros ambientes educativos da cidade. Ilustram esses movimentos realizados por essa escola as práticas culturais das ilustrações:

\footnotetext{
${ }^{10}$ As análises acerca desta escola são feitas tendo em vista observações exploratórias realizadas anteriormente e no dia da aplicação dos questionários do projeto Os Jovens e a História. Foram realizadas, também, visando à realização deste trabalho de pesquisa, observações exploratórias durante o início do ano letivo de 2017 e em suas redes sociais na internet. Acerca da escola pública central, além de processos análogos à escola pública de periferia, consultamos dissertações existentes sobre ela.

${ }^{11}$ Informações colhidas através de conversas informais junto a professores, alunos e lideranças comunitárias desde o período de aplicação dos questionários do projeto "Os Jovens e a História" nesta escola.

${ }^{12}$ Conforme vídeo gravado com prévia autorização dos estudantes para uso neste artigo:
} 
Figura 1 - Apresentação de peça teatral

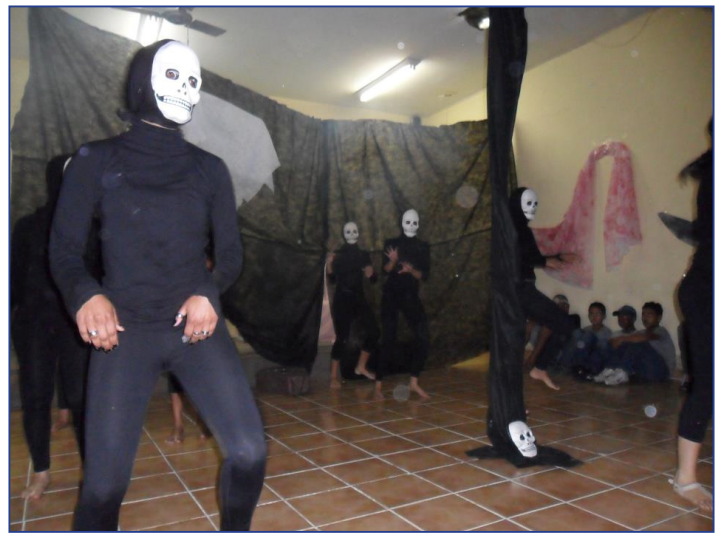

Fonte: Facebook da E. E. Coração Eucarístico. Postada em 14 nov. 2012.

Figura 2 - Leitura na praça

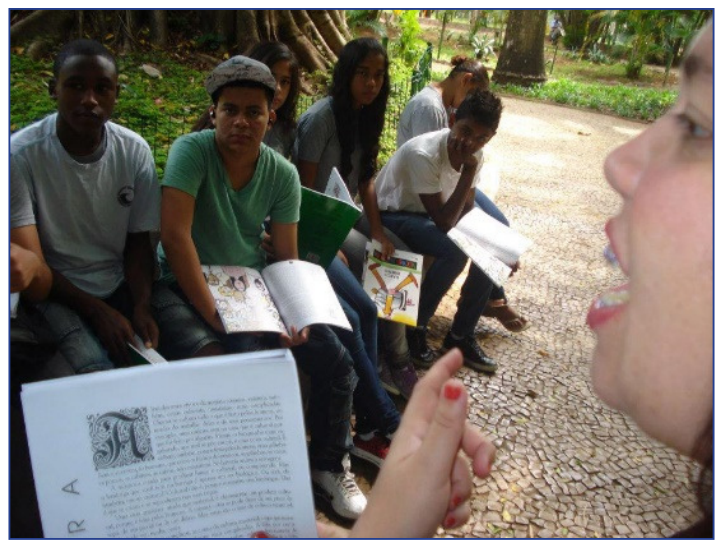

Fonte: Facebook da E.E. Coração Eucarístico. Postada em 15 nov. 2012.

Estas e outras práticas, como a realização de trabalho de campo ao acampamento Eliana Silva (01/12/12), e visita ao instituto Yorubá (24/11/12), por ocasião do projeto Semana da Consciência Negra permitem inferir que elas potencializariam relações mais sensíveis dos estudantes a múltiplos aspectos, e aprendizagens a uma cultura histórica e política. Estas ações no presente, em lugares da cidade (TUAN, 1983) e no âmbito da cultura escolar podem suscitar levantamento de questões e problemas, por vezes por eles mesmos experienciados, em sala de aula, ou em outros ambientes escolares e não escolares. Conforme observamos, nesta escola há 
um razoável comparecimento dos estudantes, professores e direção junto a estas práticas culturais, debates e outros movimentos em sua cultura escolar. Tendo situado esta escola e explicitado aspectos observados no âmbito de sua cultura escolar, passamos agora a dialogar com os dados do projeto de pesquisa Os Jovens e a História. Vejamos, então, a tabela 5.

Tabela 5 - Questão 1 (Questionário dos alunos) - O que significa a História para você?

\begin{tabular}{|c|c|c|c|c|c|c|}
\hline & 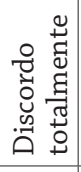 & 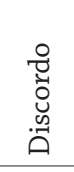 & 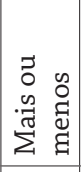 & 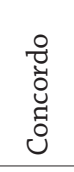 & 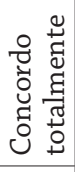 & $\stackrel{\text { तే }}{\stackrel{0}{0}}$ \\
\hline 1a. Uma matéria da escola e nada mais. & 25,0 & 57,1 & 17,9 & 0,0 & 0,0 & 100 \\
\hline $\begin{array}{l}\text { 1b. Uma fonte de coisas interessantes que estimula } \\
\text { minha imaginação. }\end{array}$ & 3,6 & 0,0 & 35,7 & 57,1 & 3,6 & 100 \\
\hline $\begin{array}{l}\text { 1c. Uma possibilidade para aprender com os erros e } \\
\text { acertos dos outros. }\end{array}$ & 7,4 & 11,1 & 48,1 & 25,9 & 7,4 & 100 \\
\hline $\begin{array}{l}\text { 1d. Algo que já morreu e passou e que não tem nada } \\
\text { a ver com a minha vida. }\end{array}$ & 25,0 & 42,9 & 17,9 & 10,7 & 3,6 & 100 \\
\hline $\begin{array}{l}\text { 1e. Um número de exemplos que ensinam o que é } \\
\text { certo e o que é errado, o que é bom e o que é mau. }\end{array}$ & 3,6 & 21,4 & 35,7 & 32,1 & 7,1 & 100 \\
\hline $\begin{array}{l}\text { 1f. Mostra o que está por trás da maneira de viver } \\
\text { no presente e explica os problemas atuais. }\end{array}$ & 3,6 & 3,6 & 32,1 & 46,4 & 14,3 & 100 \\
\hline 1g. Um amontoado de crueldades e desgraças. & 22,2 & 59,3 & 14,8 & 3,7 & 0,0 & 100 \\
\hline $\begin{array}{l}\text { 1h. Uma forma de entender a minha vida como } \\
\text { parte das mudanças na história. }\end{array}$ & 0,0 & 3,6 & 28,6 & 42,9 & 25,0 & 100 \\
\hline
\end{tabular}

Fonte: dados do Projeto Jovens e a História (2013). Elaborada pelos autores.

Atentando-nos às alternativas marcadas nas opções $1 \mathrm{~h}, 1 \mathrm{f}$ e $1 \mathrm{~b}$, observamos que a alternativa Concordo recebe os maiores escores percentuais. Supomos poder depreender destes dados que os jovens estudantes teriam uma provável tendência a atribuir sentidos à História, levando em conta aspectos das relações sociais, culturais e das tensões aí implicadas, expressando suas sensibilidades. Evidenciam estes aspectos os enunciados destas opções, como aquela da opção $1 \mathrm{f}$ "Mostra o que está por trás da maneira de viver no presente e explica os problemas atuais" (grifos nossos). Em alguma medida, podemos depreender dela uma certa relação dinâmica com as temporalidades, oportunizada pela relação com a memória histórica, 
nos termos de Rüsen, em sala de aula, e/ou durante práticas culturais, nos âmbitos da cultura escolar, conforme apreendemos durante nossas observações exploratórias. Outro aspecto a ser considerado, também na tabela 5, são as tendências percentuais às alternativas Mais ou menos e Concordo, evidenciadas nas opções 1e e 1c. Desta forma, supomos não ser desprezível considerar os aspectos dos enunciados destas opções, “[...] exemplos que ensinam [...]", e "Uma possibilidade de aprender com os erros e acertos dos outros" (grifos nossos), que mobilizaram estes jovens alunos. Potencialmente, as práticas culturais são oportunizadoras a estas experiências relacionais, que tocam dimensões do agir e do sensível, mobilizando a aspectos da cognição histórica (MIRANDA; SIMAM, 2011). Isto posto, atentamos, agora, a outro movimento que comparece no processo de atribuir sentidos à História, pelos Jovens alunos, e os fazeres do professor de História desta escola - tendo em vista o aspecto social da aula (MIRANDA, 2007) - observados através da questão 13 (Questionário dos professores).

A alternativa marcada pelo professor de História ${ }^{13}$ nas opções da questão 13 (Questionário dos professores) foi a Frequentemente. Levando em conta as tendências percentuais da questão 1 (Questionário dos alunos), acima, em suas opções 1h, 1f, 1b, 1e e 1c selecionamos, na questão 13 (Questionário dos professores), as opções 13g (Eles usam livros escolares, apostilas ou algum outro material (fotocópia)), 13a (Os estudantes ouvem as minhas exposições sobre o passado), 13h (Eles participam de atividades em grupo: encenações de teatro, visitas a museus, projetos com a comunidade), e $13 f$ (Eles ouvem fitas, cd's ou vemos filmes e vídeos sobre história), como aquelas que, supostamente, potencializam as tendências expressas na referida questão do questionário dos alunos, quanto à atribuição de sentidos à História. Em certa medida, nossas observações exploratórias corroboraram esse processo. Conforme analisamos acima, nesta escola há um razoável engajamento ponderado naquilo que tange à realização de encontros com a

\footnotetext{
${ }^{13} \mathrm{O}$ professor de História respondente deste questionário, em 2013, era designado. Tinha um contrato de trabalho temporário na rede estadual de Educação de Minas Gerais, ou seja, suas condições de trabalho eram precárias (OLIVEIRA, 2004). Situação que ainda está longe de ver solucionada. Destacamos, ainda, a necessidade de superarmos, nas políticas públicas de Educação, a cultura do aulismo e, concomitantemente, a necessidade irmos além da lei 11.738/08 (BRASIL, 2008b), e implantarmos 50\% da prática docente para pesquisa/preparação nas escolas (OLIVEIRA, 2004; DINIZ-FILHO, 2013).
} 
comunidade, trabalhos de campo junto a ocupações urbanas, visita a lugares da cidade e práticas culturais referentes à lei 11645/08 (BRASIL, 2008a), realização de peças teatrais sobre temáticas contemporâneas. No que tange à relação com a comunidade do seu entorno, observamos a participação de adultos e idosos em variadas destas práticas culturais no âmbito da escola, reinventando a cultura escolar. Como exemplo observado junto às redes sociais ${ }^{14}$ desta escola, citamos a realização de uma roda de conversa, em 15 de novembro de 2012, com uma idosa relatando aspectos de sua experiência de vida para jovens alunos do Ensino Médio. Novamente, nossas observações contribuem para evidenciar aspectos marcados na questão 13 (Questionário dos professores), nas opções 13b (Os alunos são informados do que foi bom ou mau, certo ou errado na história), $13 \mathrm{f}$ (Eles ouvem fitas, cd's ou vemos filmes e vídeos sobre história), e 13h (Eles participam de atividades em grupo: encenações de teatro, visitas a museus, projetos com a comunidade) pelo professor de História desta escola. Estes fazeres podem, em alguns aspectos, contribuir com a tendência central observada na questão 1 (Questionário dos alunos), nas opções 1e e 1c, às alternativas Mais ou menos, e Concordo, conforme se pode evidenciar na tabela 5 (Questionário dos alunos), acima. Supomos, assim, que o professor de História, a partir da sala de aula, mobiliza os jovens estudantes a algumas dimensões do agir, tendo em vista exemplos que emergem das práticas culturais experienciadas na cultura escolar, quando atenta ao "[...] que foi bom ou mau, certo ou errado na história”. Não obstante, estes aspectos podem ser aventados, também, enquanto "[...] usam livros escolares, apostilas ou algum outro material (fotocópia)" (grifos nossos).

Assim, levando em conta nossas observações exploratórias, as tendências expressas na questão 1 (Questionário dos alunos), na questão 13 (Questionário dos professores), e suas potenciais relações já sinalizadas, pode ser possível pensar no movimento de atribuição de sentidos à História considerando os seguintes aspectos: usos dos textos didáticos diversos; diálogos acerca de dimensões do passado; o envolvimento com práticas culturais no âmbito da cultura escolar; debates acerca dos fazeres docentes

\footnotetext{
${ }^{14}$ Conforme facebook da escola, em postagem de 15 nov. 2012. Acesso em 10 mar. 2017.
} 
e discentes, tanto na sala de aula como em outros espaços da escola e lugares na/da cidade. Assim analisando, pode-se depreender dos dados e de nossas observações que, nesta escola, os jovens alunos tenderiam a atribuir sentidos críticos e, por vezes, tradicionais à História e, não menos importante, o sentido exemplar. Passamos, agora, a realizar movimento análogo com a escola pública central.

\section{A ESCOLA PÚBLICA CENTRAL}

Contemporaneamente, a escola pública central atende a múltiplas diversidades juvenis, compreendidas em seus aspectos territoriais, sociais e culturais. Considerada, no meio educacional, uma escola que oferece uma educação de qualidade e com grande inserção em movimentos sociais, políticos e culturais da cidade, oportuniza aos jovens estudantes variadas práticas sociais e culturais (DINIZ-FILHO, 2013). De acordo com este trabalho, nesta escola, existem algumas práticas culturais realizadas tanto pela direção e coordenação pedagógica, quanto pelos professores de História. Processo este corroborado pelas nossas observações exploratórias, sobretudo através de conversas informais junto a estudantes e lideranças do grêmio estudantil.

Assim pensando, supomos que estas experiências sensíveis, realizadas pelos jovens alunos do primeiro ano do Ensino Médio no seio da cultura escolar, oportunizam aproximações a aspectos de uma cultura histórica e política. Ou seja, seu agir no presente, instigados desde a sala de aula, pode oportunizar relações mais problematizadoras com as temporalidades históricas e, por vezes, estimular a um engajamento ponderado.

Diante disto, supomos haver uma tendência razoável à reflexividade e comunicabilidade entre estudantes, professores, direção e coordenação pedagógica desta escola, potencializando aspectos e discussões mais democráticas, abertas e sensíveis. Não obstante, permeados por tensões e contradições, por vezes de natureza interna, outras vezes relacionados a conflitos de variadas naturezas com os gestores públicos. Retomando as práticas culturais, em conversas informais junto a jovens estudantes desta escola, foi-nos relatado que os professores de História estimulam e 
mobilizam os educandos a visitar museus, a realizar pesquisas junto à rede mundial de computadores, a visitarem praças e outros lugares de memória da cidade.

Supomos, assim, que a professora de História desta escola também instigava os jovens estudantes a estas experiências e aprendizagens. Ao analisarmos a questão 13 (Questionário dos professores), trataremos mais deste processo. Vamos agora dialogar com os dados do Projeto Os Jovens e a História acerca desta escola, cotejando com nossas observações exploratórias, iniciando pela tabela 6 .

Tabela 6 - Questão 1 (Questionário dos alunos) - O que significa a História para você?

\begin{tabular}{|c|c|c|c|c|c|c|}
\hline & 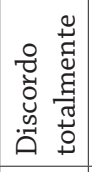 & 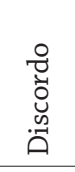 & 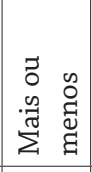 & 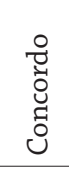 & 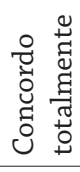 & 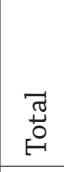 \\
\hline 1a. Uma matéria da escola e nada mais. & 61,5 & 15,4 & 15,4 & 0,0 & 7,7 & 100 \\
\hline $\begin{array}{l}\text { 1b. Uma fonte de coisas interessantes que } \\
\text { estimula minha imaginação. }\end{array}$ & 0,0 & 7,7 & 53,8 & 23,1 & 15,4 & 100 \\
\hline $\begin{array}{l}\text { 1c. Uma possibilidade para aprender com os erros } \\
\text { e acertos dos outros. }\end{array}$ & 0,0 & 0,0 & 38,5 & 53,8 & 7,7 & 100 \\
\hline $\begin{array}{l}\text { 1d. Algo que já morreu e passou e que não tem } \\
\text { nada a ver com a minha vida. }\end{array}$ & 38,5 & 38,5 & 7,7 & 7,7 & 7,7 & 100 \\
\hline $\begin{array}{l}\text { 1e. Um número de exemplos que ensinam o que é } \\
\text { certo e o que é errado, o que é bom e o que é mau. }\end{array}$ & 7,7 & 15,4 & 30,8 & 23,1 & 23,1 & 100 \\
\hline $\begin{array}{l}\text { 1f. Mostra o que está por trás da maneira de viver } \\
\text { no presente e explica os problemas atuais. }\end{array}$ & 7,7 & 0,0 & 30,8 & 30,8 & 30,8 & 100 \\
\hline 1g. Um amontoado de crueldades e desgraças. & 23,1 & 53,8 & 7,7 & 7,7 & 7,7 & 100 \\
\hline $\begin{array}{l}\text { 1h. Uma forma de entender a minha vida como } \\
\text { parte das mudanças na história. }\end{array}$ & 7,7 & 0,0 & 30,8 & 38,5 & 23,1 & 100 \\
\hline
\end{tabular}

Fonte: dados do Projeto Jovens e a História (2013). Elaborada pelos autores.

Na questão 1 (Questionário dos alunos) desta escola, destacamos as seguintes opções e suas tendências estatísticas: $1 \mathrm{~h}$ com Mais ou menos (30,8\%), Concordo (38,5\%), e Concordo totalmente (23,1\%); If com Mais ou menos (30,8\%), Concordo (30,8\%), e Concordo totalmente (30,8\%); 1c, Mais ou menos (38,5\%\%), Concordo (53,8\%), e Concordo totalmente (7,7\%). Levando em conta as variáveis estáticas destas opções, supomos poder apreender 
uma razoável tendência dos estudantes em atribuir, à História, um sentido de abertura às relações sócias e culturais mais amplas. Em outras palavras, aquilo que acontece em suas vidas apresenta alguma relação com aspectos sociais e culturais do seu entorno, conforme o próprio enunciado da opção 1h: Uma forma de entender a minha vida como parte das mudanças na História. Não é desprezível, nesta escola, o como demonstram os dados da opção 1e, conforme se pode observar na tabela 7, acima, acerca das dimensões dos exemplos. Desta atribuição de sentido à História, mais voltada à percepção dos alunos, vamos agora aos fazeres docentes manifestados na questão 13 (Questionário dos professores), pela professora ${ }^{15}$ de História desta escola, no momento em que respondeu à seguinte pergunta: $O$ que normalmente acontece em durante as aulas de História? Vale ressaltar que, excetuando a alternativa Quase nunca, essa professora de História marcou todas as outras, tendo em vista a pergunta dessa questão 13 (Questionário dos professores), e as opções apresentadas. Nesta questão, analisaremos aquilo que, segundo a docente, "normalmente acontece durante as aulas de história" (grifos nossos).

Assim, nesta questão, também levando em conta os significados atribuídos pelos jovens discentes, conforme já analisamos na tabela 7, aspectos de nossas observações e o trabalho de Diniz-Filho (2013), selecionamos as seguintes opções, com suas respectivas alternativas e escores percentuais: $13 \mathrm{a}$ (Os estudantes ouvem as minhas exposições sobre o passado), obtendo para as alternativas Frequentemente, 0,0\%; Quase sempre, 100,0\%; 13b (Os alunos são informados do que foi bom ou mau, certo ou errado na História), com Às vezes (0,0\%), Frequentemente (0,0\%), Quase sempre (100,0\%); $13 \mathrm{~g}$ (Eles usam livros escolares, apostilas ou algum outro material (fotocópia)), Às vezes (0,0\%), e Quase sempre (100,0\%). Agora, levando-se em conta, mais especificamente nossas observações e diálogos com a dissertação acima citada, escolhemos as seguintes outras opções, também com suas respectivas alternativas e medidas percentuais: 13c (Eles discutem diferentes explicações sobre o que aconteceu no passado), Às vezes $(100,0)$,

\footnotetext{
${ }^{15}$ A professora de História respondente deste questionário, em 2013, era designada. Esta é uma esta situação precária de trabalho (OLIVEIRA, 2004) que ainda persiste na rede estadual de Educação de Minas Gerais. Devido a esta situação, a docente de História não pode continuar seu trabalho nesta escola.
} 
Frequentemente (0,0\%), e Quase sempre (0,0\%); $13 \mathrm{f}$ (Eles ouvem fitas, cd's ou vemos filmes e vídeos sobre História), Às vezes (100,0), Frequentemente $(0,0 \%)$, e Quase sempre (0,0\%); e a $13 \mathrm{~h}$ (Eles participam de atividades em grupo: encenações de teatro, visitas a museus, projetos com a comunidade), Às vezes (0,0), Frequentemente (100,0\%), Quase sempre (0,0\%). Em certa medida, as respostas da professora desta escola possibilitam supor que seus fazeres em sala de aula estão implicados com aspectos dialógicos sobre tempos pretéritos e dimensões de "Um número de exemplos que ensinam [...]”. Elaborando certo exercício comparativo entre algumas opções desta questão 13 (Questionário dos professores) e a questão 1 (Questionário dos alunos) desta escola, supomos ser possível corroborar este movimento. Primeiro quanto a certo comparecimento de aspectos dialógicos acerca das discussões sobre o que aconteceu no passado. Compreendemos ser possível estabelecer certa relação entre a alternativa Às vezes, marcada pela docente de História na opção 13c (Eles discutem diferentes explicações sobre o que aconteceu no passado), e a tendência percentual manifesta nas seguintes alternativas da opção $1 \mathrm{~h}$ (Uma forma de entender a minha vida como parte das mudanças na história), com Mais ou menos (30,8\%), Concordo (38,5\%), e Concordo totalmente (23,1\%) e, de certa forma, ainda, na opção $1 \mathrm{f}$ (Mostra o que está por trás da maneira de viver no presente e explica os problemas atuais), com Mais ou menos (30,8\%), Concordo (30,8\%), e Concordo totalmente (30,8\%), ambas do questionário dos jovens alunos. Depois, acerca da dimensão dos “[...] exemplos que ensinam [...]", ao marcar, na opção 13b, (Os alunos são informados do que foi bom ou mau, certo ou errado na História), a alternativa Quase sempre, pode ser plausível pensar que este fazer da docente contribui, em alguma medida, para a tendência central na opção 1e (Um número de exemplos que ensinam o que é certo e o que é errado, o que é bom e o que é mau) do questionário dos alunos, manifesta nas alternativas Mais ou menos, com 30,8\%, Concordo $(23,1 \%)$ e Concordo totalmente (23,1\%), o que potencializa certo comparecimento de aspectos dos "exemplos que ensinam" nesta escola. Não menos importante é atentarmo-nos à alternativa Frequentemente, marcada na opção $13 \mathrm{~h}$ (Eles participam de atividades em grupo: encenações de teatro, visita a museus, projetos com a comunidade), e a alternativa Às vezes, marcada para a 
opção $13 f$ (Eles ouvem fitas, CD’s ou vemos filmes e vídeos sobre História). Supomos haver, por parte desta docente, uma atenção a explorar aspectos dos sentidos da História durante suas aulas; ou seja, o comparecimento das práticas culturais, potencializando a atribuição de sentidos à História. Novamente, reiteramos a fala, ainda que de maneira informal, enunciada para nós, enquanto realizamos nossas observações exploratórias na referida escola pública central, por uma jovem estudante do Ensino Médio, quanto ao incentivo e mobilização dos professores de História desta escola à visita a museus e outros lugares sensíveis da cidade. Desta forma, emergem reflexões acerca de tensões, contradições, afirmações e/ou continuidades, e outras dimensões sensíveis que estão comparecendo nos tempos atuais, ou na "história recente"16.

Tendo em vista o que auferimos acerca da percepção dos discentes sobre a História, dos fazeres da docente da disciplina, de nossas observações exploratórias e da pesquisa de Diniz-Filho (2013), realizada junto a esta escola, supomos que os jovens estudantes tenderiam a atribuir um sentido predominantemente mais crítico à História e, ainda, que apresentariam alguns diálogos no sentido exemplar; de modo menos importante, o comparecimento do sentido tradicional.

\section{POSSÍVEIS CONCLUSÕES...}

Nosso trabalho buscou analisar os sentidos da História atribuídos por jovens, em diálogo com aspectos de experiências de práticas culturais, emergentes na cultura escolar, oportunizadoras de apreensões de uma cultura histórica, aprendizados de uma cultura política de natureza democrática. Para tanto, fundamentamo-nos em trabalhos de Rüsen (2001; 2010; 2014), Pereira e Siman (2009), Faria filho e Vidal (2004), Moises (1992), e Abreu, Gontijo e Soihet (2007). Este estudo insere-se no projeto mais amplo, Os Jovens e a História, também realizado em cinco escolas de Belo Horizonte. Para nossa análise em profundidade, selecionamos uma

\footnotetext{
${ }^{16}$ Referência a um projeto, no campo da História, desenvolvido pelo pesquisador Luiz Fernando Cerri, disponível em um canal no youtube: <https://www.youtube.com/channel/ UCuppGdRLoDUEz3EVIdJEYBA>.
} 
escola pública da periferia e outra central por, dentre outros aspectos, pertencerem a uma mesma rede de ensino.

Para realizar esta análise, partimos do suposto que as práticas culturais possibilitam aos jovens estudantes vivenciarem experiências variadas, que contribuem tanto para a formação de uma predisposição à formação de uma cultura política de participação democrática, como para agirem temporalmente orientados. Para tanto, selecionamos a questão 1 (Questionário dos alunos) e a questão 13 (Questionário dos professores), e realizamos observações exploratórias junto às duas escolas escolhidas em Belo Horizonte, o que caracterizou uma abordagem predominantemente estatístico-descritiva.

Nossa análise mais ampla, abordando os dados estatísticos, tanto no Brasil quanto na cidade de Belo Horizonte, possibilitou depreender, das questões selecionadas do projeto, que os jovens alunos do primeiro ano do Ensino Médio, tanto no Brasil quanto em Belo Horizonte, tenderiam a atribuir sentidos críticos e, por vezes, tradicionais à História.

Quanto às duas escolas de Belo Horizonte analisadas mais verticalmente, também, como previsto, focamos nos dados da questão 1 (Questionário dos alunos) e aqueles da questão 13 (Questionário dos professores). De acordo com nossas observações exploratórias, os processos do ensinar e aprender História, desde a sala de aula até as experiências com as práticas culturais no interior da cultura escolar e em outros lugares educativos e sensíveis da cidade, potencializam, em alguma medida, a relação dos jovens alunos do primeiro ano do Ensino Médio com dimensões de uma cultura histórica e política. Essas experiências oportunizam aprendizado na relação com os outros, tanto individual como coletivamente, por vezes, através de exemplos, possibilitando levantamento de questões de variadas dimensões e naturezas. Desta forma, conforme já evidenciamos e analisamos neste trabalho, supomos comparecer a essas escolas o sentido crítico, dimensões do sentido tradicional, e não menos importante, o sentido exemplar. Não obstante, chamamos a atenção para certa diferença entre as tendências percentuais na opção 1c, referente à questão 1 (Questionário dos alunos); e 13b, referente à questão 13 (Questionário dos professores) das 
duas escolas. Na questão 1 (Questionário dos alunos), a opção 1c, na escola pública de periferia, a tendência percentual central fica com a alternativa Mais ou menos, obtendo 48,1\%; e na escola pública central, este movimento ocorre para a alternativa Concordo, obtendo 53,8\%. Em certa medida, esta diferença pode estar relacionada à alternativa Frequentemente, marcada pela professora da escola pública central na opção 13b, referente à questão 13 (Questionário dos professores), e a certa tradição de práticas culturais, debates coletivos experienciados por essa escola, desde a sala de aula de História. Isto pode levar a supor o comparecimento mais intenso da atribuição de sentido exemplar nesta escola. De outro lado, mas continuando com a questão 13 (Questionário dos professores), atentando-nos à alternativa Quase sempre, marcada na opção 13a; e a alternativa Frequentemente, para a opção 13g, hipoteticamente pensamos em processo análogo quando se trata, também, de atribuição do sentido tradicional pelos jovens alunos desta escola. Assim pensando, supomos que, nestas duas realidades escolares, haveria possíveis singularidades quanto à atribuição de sentidos à História pelos jovens estudantes do primeiro ano do Ensino Médio, sobretudo no que tange à atribuição de sentidos tradicionais e exemplar à História. Processos estes que demandam outras investigações.

De outro lado, agora, chamamos atenção para as potencialidades dos entrelaçamentos entre aspectos das culturas escolar, histórica e política, observadas exploratoriamente, sobretudo através das diferentes práticas culturais e políticas realizadas em cada uma das escolas analisadas em Belo Horizonte. De diferentes maneiras, supomos poder inferir que, em cada uma destas escolas, aquelas culturas estão vivas, pulsantes, potencialmente sensíveis, tanto a dimensões da vida prática, quanto às carências de orientação dos sujeitos estudantes do primeiro ano do Ensino Médio. Em alguns aspectos, isto pode ter potencializado dimensões da atribuição de sentidos à História. Em alguma medida, podem ser exemplo deste suposto dinamismo e interações entre cultura escolar, cultura histórica e cultura política, as diferentes práticas culturais realizadas em cada uma destas escolas, entre elas: na escola pública de periferia, visita a ocupações urbanas, os trabalhos com a comunidade e visitas a museus, tendo em vista contemplar aspectos da lei 11645/08 (BRASIL, 2008a). Na escola pública central, 
supomos poder inferir acerca das potencialidades dos fazeres docentes de História, visando a dinamizar as relações entre cultura escolar, histórica e política. Nesta direção, selecionamos, da questão 13 (Questionário dos professores), a opção 13h (Eles participam de atividades em grupo: encenações de teatro, visitas a museus, projetos com a comunidade), na qual a professora de História desta escola marcou a alternativa Frequentemente. O trabalho de Schimdt (2016b), até certo ponto, corrobora nossa inferência acerca destas potencialidades dos fazeres dos docentes de História, tendo em vista aqueles aspectos. É importante relembrar que estes processos também demandam aprofundamentos.

Outro aspecto a ser considerado, tendo em vista nosso trabalho, relaciona-se a um possível novo questionário do Projeto Os Jovens e a História. Ocorrendo este movimento, sugerimos explorar o comparecimento mais específico, sobretudo no que tange aos processos do ensinar e aprender História, das tecnologias da informação e comunicação na Educação (FERREIRA, 2010; TIMÓTEO, 2012) e dos jogos digitais (ARRUDA, 2009) quanto à atribuição de sentidos à História pelos jovens educandos do Ensino Médio. O trabalho de Timóteo (2012), entre outros aspectos, referenciando-se em Bakhtin (2009), oportuniza compreender que o conhecimento compartilhado pela rede tem o poder de dinamizar a alteridade e, desta forma, movimenta a engrenagem cognitiva, colocando em cena o exercício da palavra e da contra palavra, tão necessário ao processo de atribuição de sentido.

Por fim, entendemos ser importante aprofundar, em novas pesquisas, a apreensão e análise acerca dos sentidos atribuídos à História pelos jovens alunos do Ensino Médio por meio de suas narrativas em torno de alguma temática histórica, de maneira a buscar as relações entre as experiências culturais e políticas vivenciadas dentro e fora dos muros da escola.

\section{REFERÊNCIAS}

ABREU, M.; GONTIJO, R. SOIHET, R.; (Orgs.). Cultura politica e leituras do passado: historiografia e ensino de história. Rio de Janeiro: Civilização Brasileira/FAPERJ, 2007. 
ARRUDA, E. Jogos digitais e aprendizagens: o jogo Age of Empires III desenvolve ideias e raciocínios históricos de jovens jogadores? Brasil. 2010. Tese (Doutorado em Educação). PPGE/FAE/UFMG. Belo Horizonte. 2010. BARCA, I. A formação da consciência social dos jovens no horizonte da Educação Histórica. Educação, Santa Maria. v.37, n³, p.437-452. set./ dez. 2012.

BAROM, W. C. C. As publicações do projeto jovens e a história (2007-2014): metodologia, conceitos, temáticas, abordagens e algumas conclusões. História \& Ensino, Londrina, v. 22, n. 1, p. 71-90, jan. /jun. 2016.

BRASIL. Lei $\mathrm{n}^{\circ}$ 11.645, 10 de março de 2008a. Institui o ensino estudo da história e cultura afro-brasileira e indígena nas escolas de educação básica. Disponível em < http://portal.mec.gov.br/index. php?option=com_docman\&view=download\&alias=10101-lei-11645-1003-2008\&Itemid=30192> Acesso em 27/06/18.

BRASIL. Lei $\mathrm{n}^{\circ}$ 11.738, 10 de março de 2008b. Institui o piso nacional dos professores da educação básica e tempo de estudos. Disponível em <http://www.planalto.gov.br/ccivil_03/_ato2007-2010/2008/lei/111738. htm> Acesso em: 27/06/18.

CERRI, L. F. Ensino de história e Consciência Histórica: implicações didáticas de uma discussão contemporânea. Rio de Janeiro. FGV. 2011a.

. Cartografias Temporais: metodologias de pesquisa em consciência histórica. Educ. Real., Porto Alegre, v. 36, n.1, p. 59-81, jan./abr., 2011 b. . Canal História Recente. s.d. Disponível em: <https://www.youtube. com/channel/UCuppGdRLoDUEz3EVIdJEYBA >. Acesso em 27/06/18.

CERRI, L. F.; MOLAR, J. de O. Jovens diante da história: o nacional e o internacional na América Latina. Práxis Educativa, Ponta Grossa. v. 5, n², p.161-171, jul./dez. 2010.

CERRI, L. F.; AGUIRRE, M. C. Jovens e Sujeitos da História. Estudos IberoAmericanos. PUCRS, v. 37, nº1, p.125-140, jan./jun.2011. 
DINIZ-FILHO, M. A. Ensino de História e juventudes: a produção de sentidos no espaço escolar. 202f. Dissertação (Mestrado em Educação). PPGE/FAE/ UEMG. 2013.

E. E. Coração Eucarístico. - [Fotos de divulgação]. Disponível em: <https:// www.facebook.com/Escola-Estadual-Cora\%C3\%A7\%C3\%A3o-Eucar\%C3 \%ADstico-236743823086563/ >. Acesso em 10/03/17.

FARIA FILHO, L. M. de; VIDAL, D. G. A cultura escolar como categoria de análise e como campo de investigação na história da educação brasileira. Educação e Pesquisa, São Paulo, v.30, n.1, p. 139-159, jan. /abr. 2004.

FERREIRA, A. A. Desenvolvimento profissional de professores de história: estudo de caso de um grupo colaborativo mediado pelas tecnologias de informação e comunicação aplicadas à educação. Brasil. 2010. 260f. Tese (Doutorado em Educação). Programa de Pós-Graduação em Educação. FAE/UFMG. Belo Horizonte. 2010.

FORQUIN, J. C. Evoluções recentes do debate sobre escola, a cultura e as desigualdades na França. In: FRANCO, C. (Org.). Avaliação, ciclos e promoção na educação. Porto Alegre. Artmed. 2001. p. 101-120.

HELLER, A. Uma teoria da história. Rio de Janeiro. Civilização Brasileira. 1993.

HOBSBAWM, E. Era dos Extremos: o breve século XX: 1914 - 1991. São Paulo: Cia das Letras, 1995.

HOLLERBACH, J. D. G. O Jovem e o ensino de História: A construção da concepção de História por alunos do Ensino Médio. (Mestrado em Educação). Faculdade de Educação da Universidade Federal de Minas Gerais. 2007.

MIRANDA, S. R. Sob o signo da memória: cultura escolar, saberes docentes e história ensinada. São Paulo: Ed. da Unesp, 2007.

MIRANDA, S. R.; SIMAN, L. M. de C.; de (Orgs). Cidade, Memória e Educação. Juiz de Fora. UFJF. 2011.

MOISES, J. A. Democratização e cultura política de massa no Brasil. Lua nova, São Paulo, n. 26, p. 5-51, 1992. 
OLIVEIRA, D. A. A reestruturação do trabalho docente: precarização e flexibilização. Educação \& Sociedade. Campinas, vol. 25, n. 89, p. 11271144, set./dez. 2004.

PAIS, J. M. Consciência Histórica e Identidade: os jovens portugueses num contexto europeu. Oeiras: Celta. 1999.

PERREIRA, J. S.: SIMAN, L. M. de. Andarilhagens em Chão de Ladrilhos. In: FONSECA, Selva G. (Org.). Ensinar e Aprender História: formação, saberes e práticas educativas. Campinas. S.P. Alínea. 2009. p. 277-296.

PEREIRA, M. do C. O conhecimento tácito histórico dos adolescentes. Braga: Universidade do Minho, 2003.

RÜSEN, J. Razão Histórica: fundamentos da ciência histórica. Brasília. UNB. 2001.

RÜSEN, J. História Viva: teoria da História: formas e funções do conhecimento histórico. Brasília. UNB. 2010.

RÜSEN, J. Cultura Faz Sentido: orientações entre o ontem e o amanhã. R. J: Vozes, 2014.

SANTOS, M. O retorno do território. In: SANTOS, M.; SOUZA, M. A. A. de; SILVEIRA, M. L. (Org.). Território: globalização e fragmentação. São Paulo: HUCITEC/ANPUR, 1994. p. 11-14.

SCHIMDT, M. A. Jovens brasileiros, consciência histórica e vida prática. Revista História Hoje. V. 5, n9 9, p.31-48. 2016a.

. Aprendizagem e formação da Consciência Histórica: possibilidades de pesquisa em Educação Histórica. Educar em Revista, Curitiba. n60, p.17-42. abr./jun. 2016b.

SIMAN, L. M. de C. Práticas culturais e práticas escolares: aproximações e especificidades no ensino de história. História \& Ensino: Revista do Laboratório de Ensino de História, Londrina, v. 9, p.185-203, 2003.

TIMÓTEO, H. O. Caderno virtual: a potencialidade dos TICE no ensino e aprendizagem de história. 2012. 179 f. Dissertação (Mestrado em Educação) - PPGE/FAE/UEMG, 2012. 
TUAN, Y. Espaço e lugar: a perspectiva da experiência. São Paulo: Difel, 1983. TUTIAUX-GUILLON, N. Les questions socialmente vives, um repte per a la història i la geografia escolares? In: PAGÈS, J; SANTISTEBAN, A. Les questions socialmente vives i l'ensenuament de les ciències socials. Barcelona: UAB, 2011. p. 25-39.

WIKLUND, M. Além da racionalidade instrumental: sentido histórico e racionalidade na teoria da história de Jörn Rüsen. História da Historiografia. n. 1. p. 20-44, 2008. 


\section{QUAIS SÃO OS SENTIDOS DA HISTÓRIA? DE COMO ALGUNS JOVENS LATINO-AMERICANOS AVALIARAM FATORES DE MUDANÇA NA HISTÓRIA RECENTE}

Caroline Pacievitch

Este capítulo apresenta possibilidades de análise com dados do projeto de pesquisa Jovens e a História, explorando alguns fatores de mudança na História recente, avaliados por estudantes e seus professores. O entendimento da escala Likert, aqui, ocorreu conforme as orientações expostas em Barom (2017), em que os resultados entre -1 e +1 indicam movimento da neutralidade à concordância/discordância, enquanto resultados ligados a +1 e +2 indicam níveis progressivos de concordância, ocorrendo o inverso em resultados próximos a -1 e -2. Segundo Cerri (2016), os dados quantitativos resultantes desses questionários não representam uma amostra probabilística. Entretanto, "[...] contém informações riquíssimas sobre a realidade do ensino e da aprendizagem de História na América do Sul [...] [cujos] resultados são igualmente significativos para pensar as condições e o estado atual do ensino e da aprendizagem, assim como elementos da cultura na qual estão imersos professores, alunos e aulas" (CERRI, 2016, p. 147).

Para os fins deste capítulo, as respostas de professores e de estudantes foram cruzadas com as diferenças por país, conforme convicção política (professores) e por interesse pela política (estudantes). As descrições aqui presentes são orientadas pelos seguintes questionamentos: quais fatores são os favoritos para professores e para alunos? Em quais fatores discordam? Em quais países há maior e menor proximidade entre as opiniões de estudantes e professores?

A intenção inicial é, portanto, verificar quais são as razões mais recorrentes evocadas para explicar as mudanças do passado e do futuro, questionando se as semelhanças e diferenças poderiam ser relacionadas a algum tipo de historiografia e/ou de tendência de ensino de História específicos, e que narrativas de passado (causalidades) e expectativas de futuro podem ser inferidas; isto é, questionar que sentidos para a História são delineados nesse conjunto de dados. É possível refletir, ainda, se as razões 
mais e menos recorrentes oferecem indícios sobre a visão desses jovens e dos professores sobre seu papel como agentes da História.

As primeiras seções deste capítulo apresentam dados gerais e seus cruzamentos simples. Ao final, pretende-se analisar as constatações a partir da ideia de sentido histórico conforme Jörn Rüsen (2015), tentando contribuir para o entendimento de aspectos do pensamento histórico de estudantes e de seus professores de História, no que se refere à explicação histórica e ao sentido histórico.

\section{PANORAMA}

Nesta seção apresenta-se um panorama geral dos dados selecionados, alternando as constatações obtidas entre os estudantes e seus professores e arriscando alguns cruzamentos. Na tabela 1 encontram-se os resultados obtidos que orientam as análises. Os números parecem refletir a ideia de que as inovações no campo da tecnologia e das invenções, junto com interesses econômicos e conflitos sociais foram os fatores mais relevantes de mudança, na avaliação dos estudantes. Fatores de tipo individual e coletivo encontramse tanto entre os mais quanto nos menos relevantes, embora priorizem, sem dúvida, questões conjunturais, sendo os cientistas e engenheiros os únicos indivíduos que aparecem como fatores relevantes, à frente dos movimentos e conflitos sociais. Temas que, atualmente, são muito relevantes no debate político mundial, como líderes religiosos e migrações não eram vistos como relevantes quando esses jovens responderam à questão.

Tabela 1 - Comparação de médias* das respostas de professores e estudantes em cada amostra nacional à questão Que influência você acha que tiveram os seguintes fatores na mudança da vida das pessoas desde 1970 até hoje?

\begin{tabular}{|c|c|c|c|c|c|c|c|c|c|c|}
\hline & 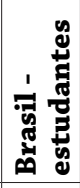 & 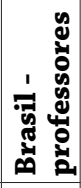 & 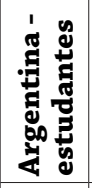 & 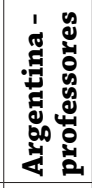 & 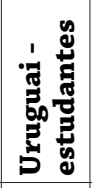 & 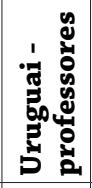 & 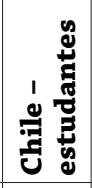 & 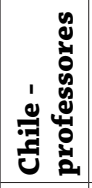 & 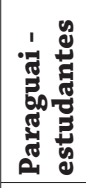 & 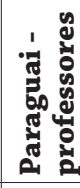 \\
\hline $\begin{array}{l}\text { 19a. Invenções } \\
\text { técnicas e } \\
\text { mecanização }\end{array}$ & 1,12 & 1,56 & 0,91 & 0,86 & 0,98 & 0,57 & 1,01 & 1,38 & 0,67 & 1,00 \\
\hline
\end{tabular}




\begin{tabular}{|c|c|c|c|c|c|c|c|c|c|c|}
\hline & 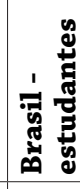 & 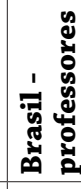 & 吾 & 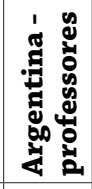 & . & 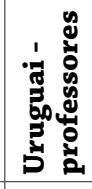 & 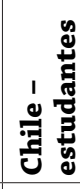 & d & 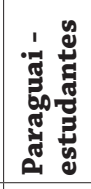 & . \\
\hline $\begin{array}{l}\text { 19b. Movimentos e } \\
\text { conflitos sociais }\end{array}$ & 0,69 & 1,17 & 0,69 & 1,34 & 0,72 & 1,38 & 1,11 & 1,46 & 0,56 & 1,13 \\
\hline $\begin{array}{l}\text { 19c. Reis, } \\
\text { presidentes e } \\
\text { personagens } \\
\text { politicamente } \\
\text { importantes no } \\
\text { poder }\end{array}$ & 0,49 & 0,26 & 0,38 & $-0,69$ & 0,39 & $-0,88$ & 0,79 & $-0,46$ & 0,60 & $-0,25$ \\
\hline $\begin{array}{l}\text { 19d. Reformas } \\
\text { políticas }\end{array}$ & 0,64 & 0,76 & 0,57 & 0,75 & 0,72 & 0,50 & 0,84 & 0,85 & 0,54 & 0,88 \\
\hline $\begin{array}{l}\text { 19e. Fundadores de } \\
\text { religiões e chefes } \\
\text { religiosos }\end{array}$ & 0,24 & 0,21 & $-0,11$ & $-0,68$ & $-0,01$ & $-0,75$ & 0,22 & 0,15 & 0,51 & 0,25 \\
\hline $\begin{array}{l}\text { 19f. } \\
\text { Desenvolvimento } \\
\text { da ciência e do } \\
\text { conhecimento }\end{array}$ & 1,15 & 1,53 & 1,04 & 0,91 & 1,20 & 0,88 & 1,25 & 1,46 & 1,02 & 1,13 \\
\hline $\begin{array}{l}\text { 19g. Guerras e } \\
\text { conflitos }\end{array}$ & 0,53 & 0,88 & 0,74 & 0,95 & 0,79 & 1,00 & 1,10 & 1,31 & 0,75 & 0,75 \\
\hline $\begin{array}{l}\text { 19h. Interesses } \\
\text { econômicos e } \\
\text { concorrência } \\
\text { econômica }\end{array}$ & 0,78 & 1,38 & 0,71 & 1,27 & 0,70 & 1,75 & 0,90 & 1,69 & 0,88 & 1,25 \\
\hline $\begin{array}{l}\text { 19i. Filósofos, } \\
\text { pensadores e pessoas } \\
\text { instruídas }\end{array}$ & 0,25 & 0,23 & 0,17 & 0,04 & $-0,07$ & $-0,13$ & 0,55 & 0,46 & 0,62 & 0,63 \\
\hline $\begin{array}{l}\text { 19j. Revoluções } \\
\text { políticas }\end{array}$ & 0,49 & 0,61 & 0,53 & 0,69 & 0,62 & 1,00 & 0,87 & 1,23 & 0,47 & 0,75 \\
\hline $\begin{array}{l}\text { 19k. Problemas } \\
\text { ambientais }\end{array}$ & 0,70 & 1,09 & 0,42 & 0,11 & 0,15 & $-0,88$ & 0,61 & 1,08 & 0,63 & 1,00 \\
\hline 19l. Migrações & 0,39 & 0,72 & 0,37 & 0,54 & 0,24 & 0,13 & 0,51 & 1,23 & 0,61 & 1,50 \\
\hline $\begin{array}{l}\text { 19m. Organização } \\
\text { dos trabalhadores }\end{array}$ & 0,49 & 0,83 & 0,34 & 0,58 & 0,36 & 0,63 & 0,69 & 0,92 & 0,39 & 0,63 \\
\hline 19n. Esforço pessoal & 0,36 & 0,49 & 0,18 & $-0,34$ & 0,01 & $-0,25$ & 0,31 & 0,08 & 0,60 & 0,50 \\
\hline $\begin{array}{l}\text { 19o. Cientistas e } \\
\text { engenheiros }\end{array}$ & 0,89 & 0,82 & 0,50 & 0,00 & 0,42 & $-0,25$ & 0,68 & 0,38 & 0,68 & 0,75 \\
\hline
\end{tabular}

Fonte: Dados do Projeto Jovens e a História (2013). Elaboração da autora.

* Médias aritméticas das respostas obtidas pela transformação da escala Likert na seguinte escala numérica: Muito pouca = $-2 ;$ Pouca $=-1 ;$ Média $=0 ;$ Grande = $1 ;$ Muito grande $=2$. 
Entre os professores, como se observa, as tendências são muito parecidas. A principal diferença entre estudantes e professores encontra-se na intensidade das respostas, pois os docentes afastam-se mais da neutralidade do que os jovens. Estes também atribuem maior importância para fatores individuais, como Cientistas e engenheiros; Esforço pessoal; Líderes religiosos e Personagens politicamente importantes no poder. Os jovens atribuem muito menos importância aos Interesses econômicos e à concorrência econômica, e aos movimentos e conflitos sociais do que seus professores, em geral.

$\mathrm{Na}$ Tabela 2, o olhar dirige-se para as tendências de futuro.

Tabela 2 - Comparação de médias* das respostas de professores e estudantes em cada amostra nacional à questão Que influência você acha que terão os seguintes fatores na mudança da vida das pessoas de agora até 2050?

\begin{tabular}{|c|c|c|c|c|c|c|c|c|c|c|}
\hline & 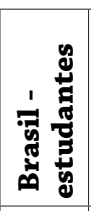 & 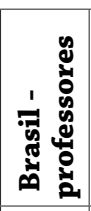 & 总 & 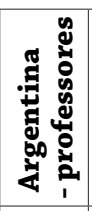 & 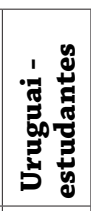 & 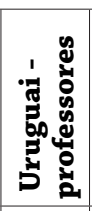 & 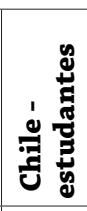 & 总 & 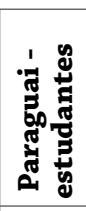 & 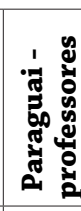 \\
\hline $\begin{array}{l}\text { 20a. Invenções } \\
\text { técnicas e } \\
\text { mecanização }\end{array}$ & 1,34 & 1,63 & 1,05 & 1,29 & 1,10 & 1,25 & 1,03 & 1,54 & 1,00 & 1,63 \\
\hline $\begin{array}{l}\text { 20b. Movimentos e } \\
\text { conflitos sociais }\end{array}$ & 0,53 & 1,10 & 0,64 & 1,27 & 0,67 & 1,00 & 1,07 & 1,46 & 0,57 & 1,38 \\
\hline $\begin{array}{l}\text { 20c. Reis, } \\
\text { presidentes e } \\
\text { personagens } \\
\text { politicamente } \\
\text { importantes no } \\
\text { poder }\end{array}$ & 0,15 & 0,04 & 0,05 & $-1,00$ & 0,02 & $-1,38$ & 0,22 & $-0,69$ & 0,30 & $-0,50$ \\
\hline $\begin{array}{l}\text { 20d. Reformas } \\
\text { políticas }\end{array}$ & 0,46 & 0,69 & 0,51 & 0,68 & 0,57 & 0,63 & 0,52 & 1,00 & 0,65 & 1,14 \\
\hline $\begin{array}{l}20 \text { e. Fundadores de } \\
\text { religiões e chefes } \\
\text { religiosos }\end{array}$ & $-0,05$ & 0,11 & $-0,46$ & $-0,76$ & $-0,37$ & $-0,88$ & $-0,34$ & $-0,23$ & 0,16 & 0,13 \\
\hline $\begin{array}{l}20 f . \\
\text { Desenvolvimento } \\
\text { da ciência e do } \\
\text { conhecimento }\end{array}$ & 1,31 & 1,66 & 1,14 & 1,20 & 1,23 & 1,50 & 1,20 & 1,77 & 1,15 & 1,50 \\
\hline $\begin{array}{l}\text { 20g. Guerras e } \\
\text { conflitos }\end{array}$ & 0,29 & 0,90 & 0,60 & 0,86 & 0,52 & 0,63 & 0,84 & 1,38 & 0,57 & 1,25 \\
\hline $\begin{array}{l}\text { 20h. Interesses } \\
\text { econômicos e } \\
\text { concorrência } \\
\text { econômica }\end{array}$ & 1,00 & 1,45 & 0,87 & 1,34 & 0,86 & 1,63 & 1,07 & 1,77 & 1,07 & 1,63 \\
\hline
\end{tabular}




\begin{tabular}{|c|c|c|c|c|c|c|c|c|c|c|}
\hline & 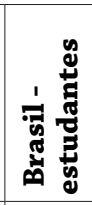 & 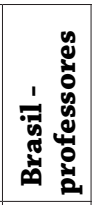 & 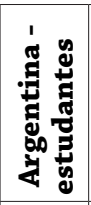 & 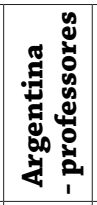 & 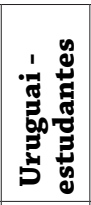 & 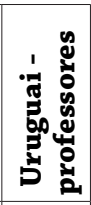 & & 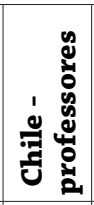 & 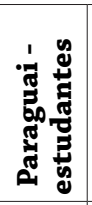 & 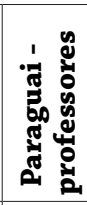 \\
\hline $\begin{array}{l}\text { 20i Filósofos, } \\
\text { pensadores e } \\
\text { pessoas instruídas }\end{array}$ & 0,00 & 0,34 & $-0,12$ & $-0,16$ & $-0,30$ & $-0,25$ & 0,22 & 0,23 & 0,15 & 0,63 \\
\hline $\begin{array}{l}\text { 20j. Revoluções } \\
\text { políticas }\end{array}$ & 0,37 & 0,72 & 0,41 & 0,64 & 0,39 & 0,00 & 0,75 & 1,38 & 0,29 & 1,14 \\
\hline $\begin{array}{l}\text { 20k. Problemas } \\
\text { ambientais }\end{array}$ & 1,14 & 1,64 & 1,08 & 0,96 & 0,63 & 0,00 & 1,02 & 1,77 & 0,94 & 1,63 \\
\hline 201. Migrações & 0,16 & 0,85 & 0,13 & 0,49 & 0,04 & 0,25 & 0,30 & 1,23 & 0,44 & 1,63 \\
\hline $\begin{array}{l}20 \mathrm{~m} \text {. Organização } \\
\text { dos trabalhadores }\end{array}$ & 0,41 & 0,79 & 0,24 & 0,73 & 0,18 & 0,88 & 0,57 & 1,15 & 0,31 & 1,13 \\
\hline $\begin{array}{l}\text { 20n. Esforço } \\
\text { pessoal }\end{array}$ & 0,45 & 0,75 & 0,18 & $-0,18$ & 0,30 & 0,63 & 0,38 & 0,38 & 0,61 & 1,13 \\
\hline $\begin{array}{l}\text { 20o. Cientistas e } \\
\text { engenheiros }\end{array}$ & 1,12 & 1,06 & 0,66 & 0,26 & 0,92 & 0,63 & 0,79 & 0,69 & 0,81 & 1,13 \\
\hline
\end{tabular}

Fonte: Dados do Projeto Jovens e a História (2013). Elaboração da autora.

* Médias aritméticas das respostas obtidas pela transformação da escala Likert na seguinte escala numérica: Muito pouca = $-2 ;$ Pouca $=-1 ;$ Média $=0 ;$ Grande $=1 ;$ Muito grande $=2$.

Com relação aos fatores de mudança para o futuro, os estudantes permanecem basicamente com as mesmas perspectivas, com a diferença de que as questões ambientais tornam-se mais prementes. Inovações técnicas, cientistas e engenheiros, ciência e conhecimento continuam sendo os fatores mais mencionados, seguidos de perto pelos interesses econômicos. Em um lugar intermediário encontram-se novamente os Movimentos e conflitos sociais, as Reformas políticas, Guerras e conflitos e Revoluções políticas. Esforço pessoal e organização dos trabalhadores recebem notações próximas da neutralidade, assim como Migrações e Reis, presidentes e personagens politicamente importantes no poder. A grande diferença em relação às perspectivas de passado encontra-se na presença de números negativos atribuídos aos fundadores de religiões e chefes religiosos e aos Filósofos, pensadores e pessoas instruídas. Como visto, apenas em alguns países essas médias chegavam a números negativos. É tentador questionar se, após a intensa divulgação da crise de refugiados na Europa e a intensificação de atos de grupos baseados em fundamentalismo religioso, os 
estudantes seguiriam valorizando da mesma forma o poder das religiões e das migrações como fatores de mudança.

Em síntese, na comparação geral entre as expectativas para o futuro e levantamento de causas no passado, nota-se que os jovens estavam mais confiantes nos seguintes fatores de mudança no futuro: as invenções técnicas e a mecanização, a ciência e o conhecimento, os interesses econômicos, os problemas ambientais (como visto, os que mais cresceram), o esforço pessoal e cientistas e engenheiros. Todos os demais diminuíram, e líderes religiosos e filósofos e pensadores atingiram números negativos. As diferenças entre estudantes dos quatro países são mais intensas nas análises que fazem sobre o passado do que sobre o futuro. Ao indicar fatores de mudança para o futuro eles se mostram, em geral, mais prudentes, atingindo números mais próximos da neutralidade.

Com relação aos professores, também se notam poucas alterações entre a análise de passado e as perspectivas de futuro. O mesmo movimento percebido entre os jovens - crescimento dos Problemas ambientais como fatores de mudança - aparece nas respostas dos docentes. Ciência e conhecimento, Inovações técnicas e Interesses econômicos seguem os favoritos, mas agora seguidos de Problemas ambientais e de Movimentos e conflitos sociais. Este último, como visto, é o que tem diferenciado as respostas de estudantes e de professores. Outra semelhança em relação aos estudantes são as médias negativas para Reis, presidentes e personagens politicamente importantes e Fundadores de religiões e chefes religiosos, que já tinham médias negativas nas respostas sobre o passado, mas que se aprofundaram para o futuro. Guerras e conflitos, Organização dos trabalhadores, Migrações, Revoluções e reformas políticas continuam com valor intermediário. Com valores muito próximos a zero (além de personagens políticos e religiosos) encontram-se o Esforço pessoal e Filósofos, pensadores e pessoas instruídas. Tanto entre professores quanto entre estudantes há maior valorização de processos coletivos do que individuais (como visto, no Brasil essa diferença é menor do que nos outros países), à exceção dos cientistas, que estão ora em posições intermediárias, ora como fatores favoritos de mudança. Tais constatações permitem pensar que professores e jovens entendem esse intervalo de 80 anos como História (ou futuro) 
próximos, em que não se notam grandes rupturas em relação aos fatores que explicam mudanças.

\section{POSSIBILIDADES DE ANÁLISE}

Dessas constatações iniciais desenham-se possibilidades de análise. A primeira foi pensar em cruzamentos em relação às convicções políticas dos docentes; outras, sobre os conteúdos favoritos dos estudantes. Antes disso, porém, outras três questões para os estudantes chamaram a atenção, pelo potencial de correlação com os fatores de mudança apontados nessas duas primeiras: como você pensa que era a vida do seu país há 40 anos? Como você pensa que será a vida do seu país em 40 anos? Como você acha que será a sua vida daqui a 40 anos? Não há equivalente, no questionário de professores, a essas perguntas. Mesmo assim, considera-se importante explorar essas possibilidades entre os jovens, tendo em vista seu potencial para perseguir as questões ligadas à agência histórica e a sentido histórico.

O gráfico 1 ilustra as respostas à primeira pergunta, em que os participantes acreditam que o que melhor caracterizava a vida do seu país há 40 anos foram os conflitos políticos. É interessante, pois esse não foi um dos fatores de mudança mais fortes apontados por eles nas questões anteriores. Evidentemente, não havia a opção de escolha do tipo agitada por diversas inovações tecnológicas. Além disso, essa pergunta se referia à vida no país, enquanto a anterior tratava do mundo. Os jovens também acreditam que, depois dos conflitos políticos, o que mais caracterizava a vida no país eram os problemas entre ricos e pobres e, próximo da neutralidade, a situação de exploração por um país estrangeiro e a poluição. Os estudantes discordam de que o país era Próspero e rico, Pacífico ou Democrático.

Quando são convidados a projetar o futuro do país nos próximos 40 anos (Gráfico 2), a poluição torna-se o maior problema, saltando de -0,08 para 0,95 . O país seguirá agitado por conflitos políticos e entre ricos e pobres, mas há maior segurança quanto ao fato de que será uma democracia (hoje seria diferente?). Os estudantes têm dúvidas se a sociedade será Próspera e rica, e duvidam de que seja Pacífica ou Explorada por um país estrangeiro. Efetivamente, estes três últimos fatores estão próximos da neutralidade. 
Gráfico 1 - Comparação das médias * das respostas dos estudantes à questão Como você pensa que era a vida do seu país há 40 anos?

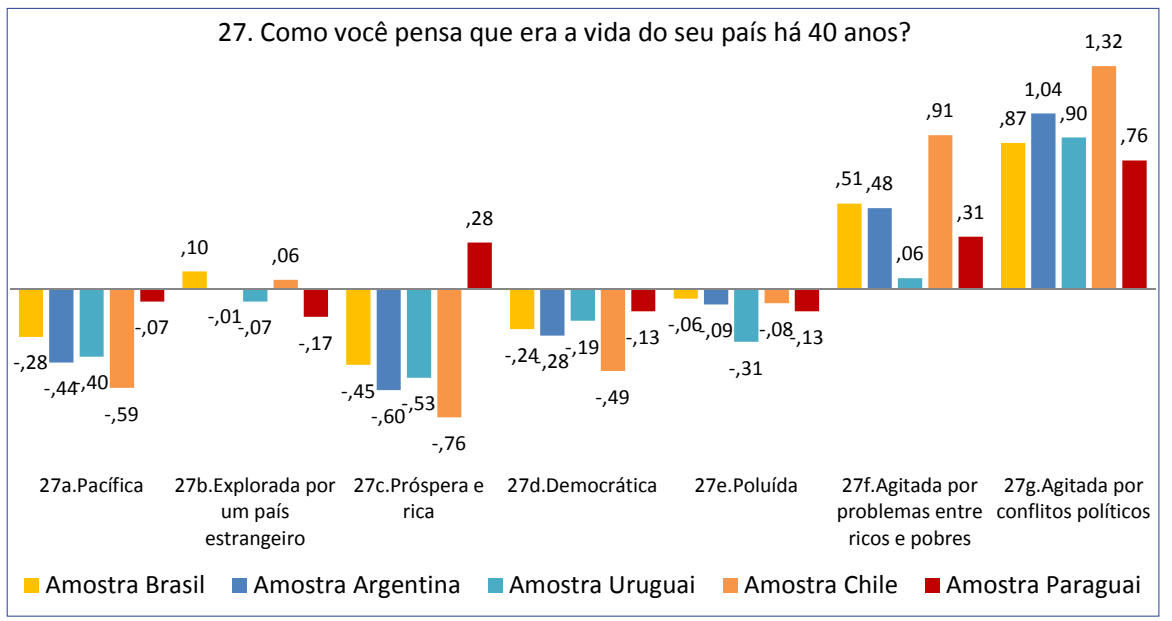

Fonte: Projeto Jovens e a História (2013). Elaboração da autora.

* Médias aritméticas das respostas obtidas pela transformação da escala Likert na seguinte escala numérica: Muito dificilmente $=-2$; Dificilmente $=-1$; Talvez $=0$; Provavelmente $=1$; Muito provavelmente $=2$.

Gráfico 2 - Comparação das médias * das respostas dos estudantes à questão Como você acha que será a vida do seu país daqui a 40 anos?

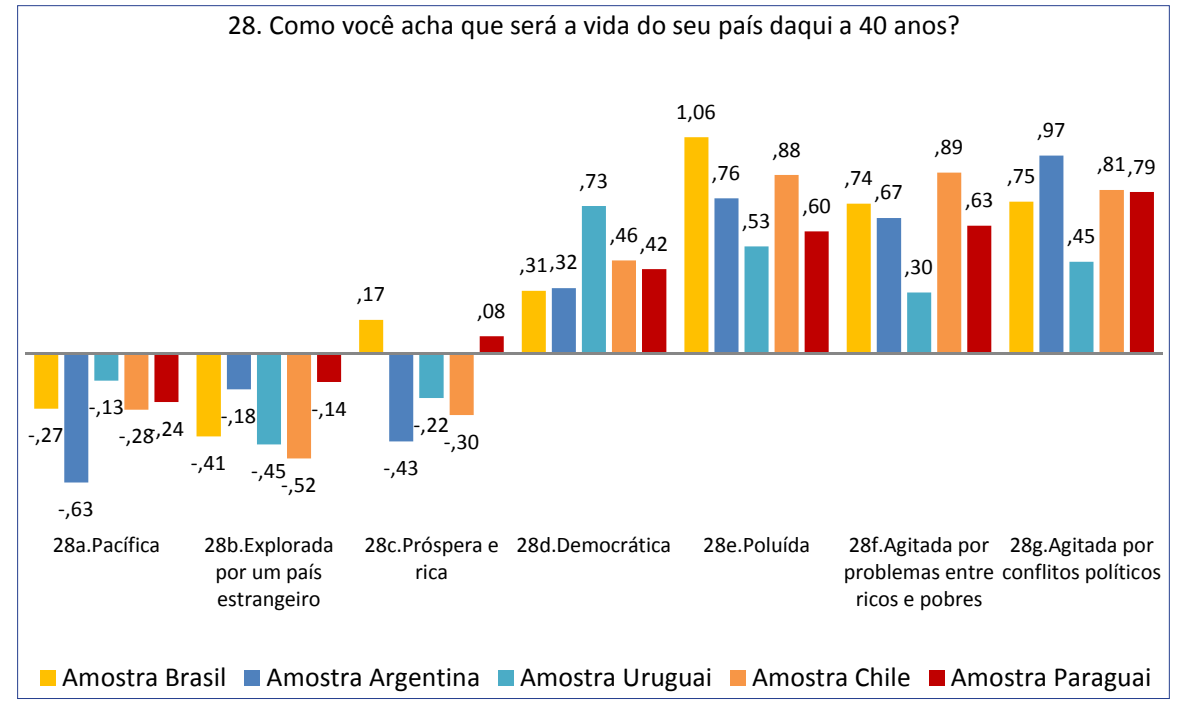

Fonte: Projeto Jovens e a História (2013). Elaboração da autora.

* Médias aritméticas das respostas obtidas pela transformação da escala Likert na seguinte escala numérica: Muito dificilmente $=-2$; Dificilmente $=-1$; Talvez $=0$; Provavelmente $=1$; Muito provavelmente $=2$. 
Comparando as interpretações de passado entre estudantes de Brasil, Argentina, Uruguai, Chile e Paraguai, nota-se que os estudantes chilenos se destacam pela maior intensidade de suas respostas; isto é, afastam-se mais do que os outros da neutralidade, principalmente em relação à dúvida sobre a existência de Paz, de Prosperidade e de Democracia. Também são mais incisivos que os demais ao acreditar que seu país era agitado por Conflitos políticos e entre ricos e pobres. Os estudantes paraguaios e os brasileiros são os que menos afirmam que seu país atravessava conflitos políticos há 40 anos. Os paraguaios são os únicos que apresentam valores positivos (embora bem próximos de zero) para o fato de que seu país era uma sociedade próspera e rica há 40 anos.

Quanto às projeções de futuro, entre os estudantes argentinos há os maiores níveis de pessimismo. Duvidam que seu país seja pacífico, não projetam prosperidade ou riqueza e estão mais seguros do que os demais de que será agitada por conflitos políticos. Os estudantes brasileiros aproximam-se dos demais em todos os casos, exceto em um: é o único país a apresentar valor positivo no fator Prosperidade e riqueza. Obviamente, é um número pequeno, mais próximo da neutralidade, mas, na comparação com os demais, é um destaque interessante. Os uruguaios parecem ser os mais otimistas de todos no que se refere à estabilidade democrática, à poluição e à existência de conflitos entre ricos e pobres ou políticos. Já os chilenos apenas duvidam mais do que os outros de que o Chile pode vir a ser explorado por um país estrangeiro nos próximos 40 anos.

$O$ fato de argentinos e uruguaios serem os mais pessimistas e os mais otimistas, respectivamente, pode sinalizar conexões entre as compreensões desses jovens e o clima político vivido em seus países no período em que os questionários foram aplicados. Mas indica, principalmente, a importância de replicar investigações dessa envergadura ao longo do tempo, tendo em vista as mudanças políticas vividas pela Argentina após a eleição de Macri. Além disso, teria sido extremamente interessante comparar essas respostas com as dos docentes.

Uma possibilidade de conexão mostra-se com a questão $\mathrm{n}^{0} 29$, sobre como os jovens projetam sua própria vida daqui a 40 anos. Tendo em 
vista que apresentam baixas expectativas sobre a estabilidade política e social de seu país, seriam, também, pessimistas em relação a seu próprio futuro? Ao observar o gráfico 3, parece que os jovens estão medianamente seguros de que terão uma boa vida, em que haverá, principalmente, bons amigos, trabalho prazeroso, e uma família feliz e harmoniosa, com pouca participação política. Os jovens também creem que terão tempo livre para o lazer, rendimentos elevados e liberdade política e individual.

Gráfico 3 - Comparação das médias * das respostas dos estudantes à questão Como você pensa que será a sua vida daqui a 40 anos?

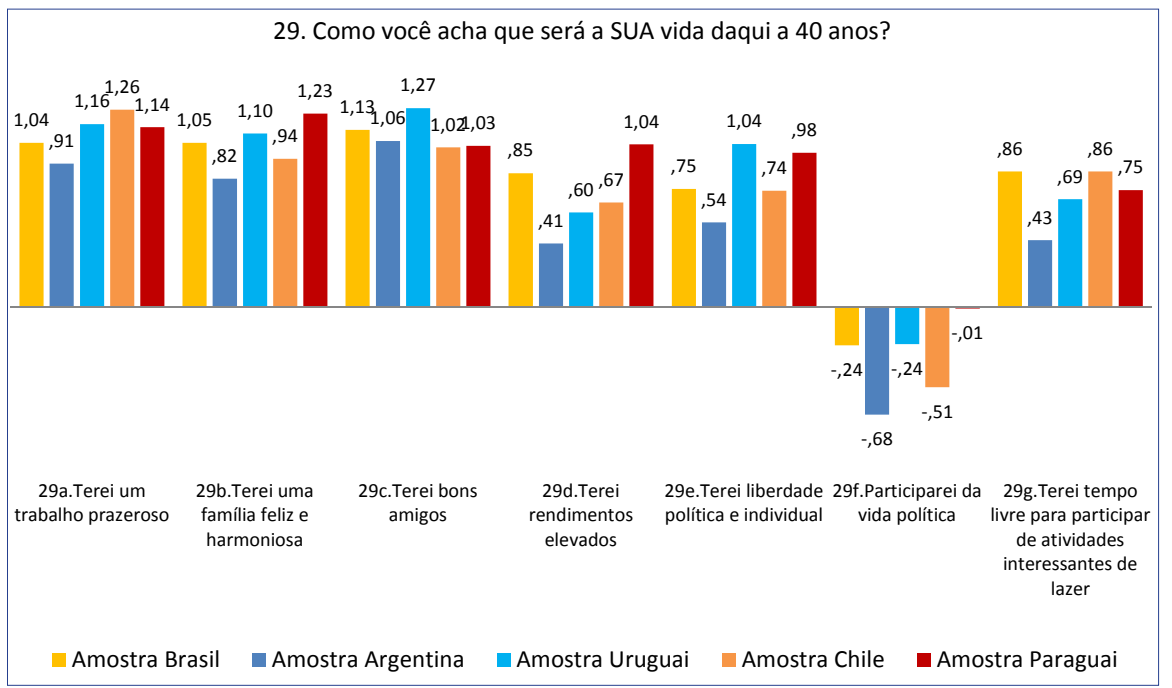

Fonte: Projeto Jovens e a História (2013). Elaboração da autora.

* Médias aritméticas das respostas obtidas pela transformação da escala Likert na seguinte escala numérica: Muito dificilmente $=-2$; Dificilmente $=-1$; Talvez $=0$; Provavelmente $=1$; Muito provavelmente $=2$.

Na comparação entre países, conforme apresenta o Gráfico 3, novamente entre os argentinos há as médias mais baixas. Assim, apesar de projetarem um futuro positivo para si próprios, são mais prudentes do que os demais em todos os aspectos, à exceção dos bons amigos, em que os chilenos são os menos convencidos. Os argentinos duvidam principalmente de que poderão ter rendimentos elevados, oportunidades de lazer e participação política. Os uruguaios novamente estão entre os mais confiantes em seu futuro, à exceção da fruição de rendimentos elevados e de lazer, destacando-se otimismo quanto à liberdade política e individual e seu 
interesse pela participação política que, embora seja negativo, empata com os jovens brasileiros, por serem os que mais se aproximam da neutralidade, sendo os argentinos e chilenos os, aparentemente, menos interessados. Os paraguaios parecem ser os mais confiantes na possibilidade de liberdade e de participação política.

Neste sentido, apesar de, para o conjunto de seus países serem mais pessimistas do que em relação à vida pessoal, seus projetos de vida refletem a interpretação geral que fazem da trajetória de seu país em um intervalo de 80 anos. Entretanto, é difícil conectar com as questões em análise no tópico anterior.

\section{SERIA A POLÍTICA UMA VARIÁVEL IMPORTANTE?}

Uma possibilidade de análise utilizando os dados dos professores é com relação a suas opções políticas na hora do voto, expressas nos gráficos 4 e 5 . O questionário permitiu fazer o cruzamento entre as opções docentes nas eleições e os fatores de mudança no tempo mais conectados. Assim, isolaram-se dados de professores brasileiros que votam à direita e centro-direita, ao centro e à esquerda e centro-esquerda, cruzando com as respostas às questões sobre fatores de mudança no passado e no futuro.

Comparando as respostas, nota-se que predomina a concordância entre os docentes, independentemente de sua convicção política para o voto. Apenas em alguns aspectos há diferenças significativas, tanto para o passado quanto para o futuro: na importância atribuída a líderes e movimentos religiosos, ao esforço pessoal e à importância de reis e personagens políticos no poder. Nesses casos, professores que preferem partidos de direita estão ligeiramente acima dos demais. Apesar de terem maior tendência a valorizar ações individuais, os professores que votam à direita e centro-direita são os que menos confiam em cientistas e engenheiros como fatores de mudança, tanto para o passado quanto para o futuro. As respostas desses docentes são estáveis, quando se comparam opções feitas para o futuro e para o passado, embora se tornem menos confiantes quanto ao papel dos líderes políticos, religiosos e filósofos, bem como das guerras, revoluções políticas e migrações para o futuro. Pensam, ainda, que os movimentos de 
trabalhadores, o esforço pessoal, os problemas ambientais, a ciência e as invenções terão maior força no futuro do que no passado.

Gráfico 4 - Professores brasileiros. Escolha eleitoral e fatores de mudança no passado

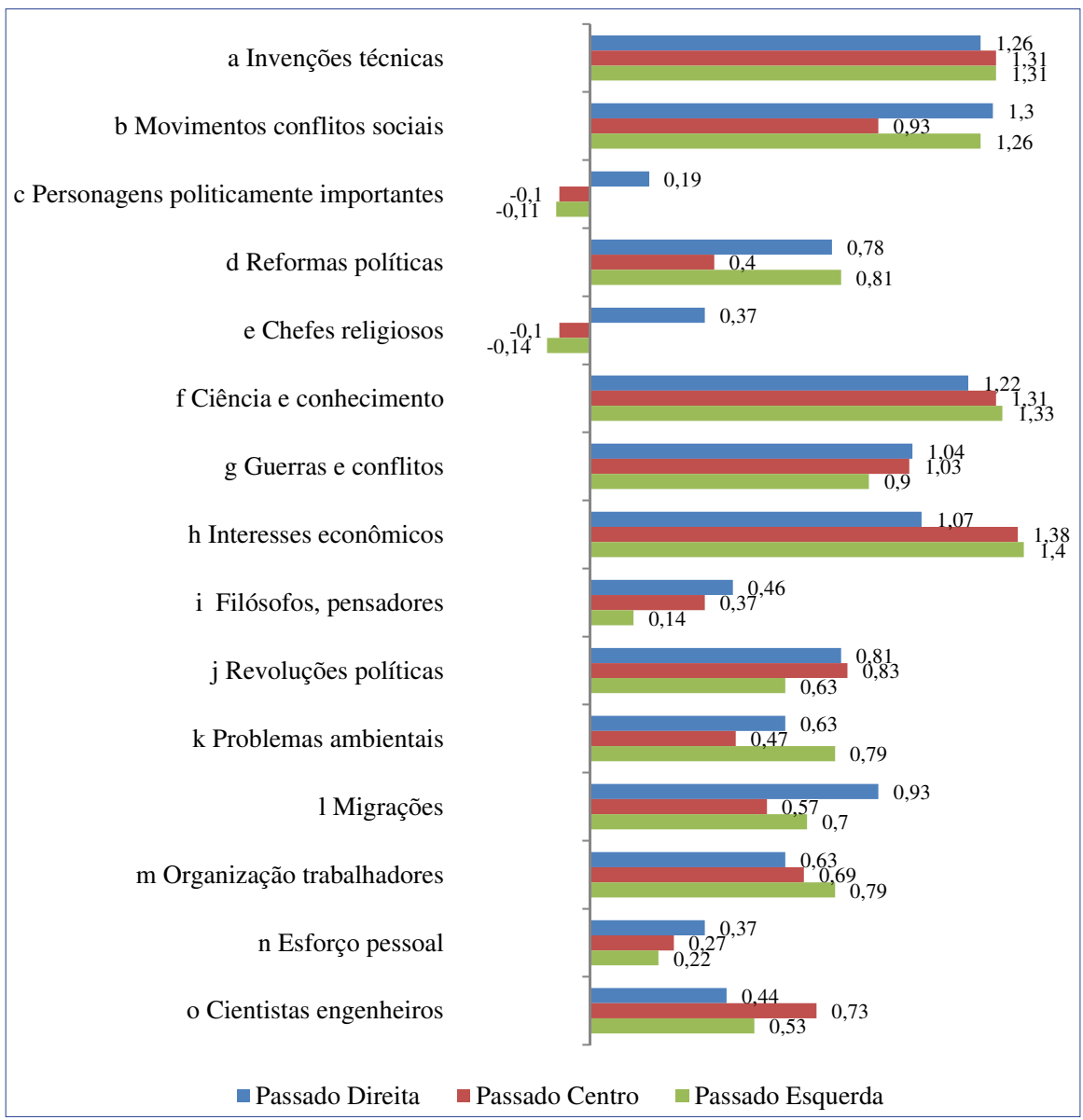

Fonte: Projeto Jovens e a História. 2012.

Quanto aos professores que afirmam preferir partidos de centro, comparando a valorização atribuída aos fatores para o passado e o futuro, a tendência segue a média geral: mostram-se mais seguros quanto ao valor da ciência, das invenções, dos cientistas e engenheiros, dos problemas ambientais, dos movimentos sociais e dos interesses econômicos para mudanças no futuro em relação ao passado. Também acreditam que o esforço pessoal 
será um fator mais importante no futuro do que no passado. Estão ainda menos convencidos do poder de reis e personagens políticos importantes, de filósofos e pensadores, de líderes religiosos, de guerras, das revoluções e das migrações como fatores de mudança para o futuro.

Gráfico 5 - Professores brasileiros. Escolha eleitoral e fatores de mudança no futuro

a Invenções técnicas
b Movimentos conflitos sociais
c Personagens politicamente importantes $0,0,290,15$
d Reformas políticas
e Chefes religiosos
f Ciência e conhecimento
g Guerras e conflitos
h Interesses econômicos
i Filósofos, pensadores
j Revoluções políticas
k Problemas ambientais
1 Migrações

Fonte: Projeto Jovens e a História. 2012.

O panorama comparativo para os professores que afirmam votar em partidos de esquerda e centro-esquerda é basicamente o mesmo que os de centro, com a diferença de que estão ligeiramente menos convencidos do poder dos movimentos sociais e das reformas políticas, mas continuam bastante confiantes em ciência, invenções, engenheiros, esforço pessoal, movimentos dos trabalhadores, revoluções políticas, guerras, problemas ambientais e interesses econômicos. Assim como os demais, duvidam que 
reis e personagens políticos importantes e líderes religiosos sejam fatores significativos de mudança, tanto no passado quanto no futuro (mais intensamente no futuro do que no passado).

Essas constatações, conectadas com pesquisas anteriores (PACIEVITCH, 2014), ajudam a demonstrar que convicção ou escolha política não é um fator de influência significativa sobre as interpretações e opiniões docentes sobre os fatores de mudança histórica no passado recente e no futuro próximo, embora possam ser percebidos alguns elementos de diferenciação. Mesmo assim, o esforço pessoal, fator que poderia ser reconhecido como tipicamente liberal ou de direita, ligado à meritocracia, é valorizado de forma semelhante nos três grupos de docentes. Isto poderia se conectar ao próprio papel de professor, que estimula os estudantes e crê que seu esforço pessoal possa fazer a diferença em suas vidas? Ou se trata de um reflexo de perspectivas mais esperançosas sobre o futuro e a democracia, em que desigualdades cristalizadas já não são fatores tão importantes de impedimento de ascensão social? Quiçá, os casos de professores ativistas, no sentido atribuído por Soares (2008) e criticado por Paim (2005), não se expliquem por suas convicções políticas, mas por fragilidades na formação historiográfica, didática e, por que não, ética, não se explicando apenas pela opção na hora do voto.

Aos estudantes não se questionou sobre escolhas eleitorais, mas sobre o quanto consideravam a política um tema importante. As respostas foram divididas em três grupos: aqueles que possuíam interesse e grande interesse por política, os que possuíam algum interesse por política e os que possuíam pequeno ou muito pequeno interesse por política. Cada grupo foi cruzado com as respostas dadas aos fatores de mudança para o passado e para o futuro, a fim de constatar semelhanças ou diferenças.

Todos os três grupos de estudantes, em geral, acompanham as médias para as questões. A curva de valores mostra que é descendente ou ascendente, em geral, nos mesmos aspectos. Os estudantes que possuem grande e algum interesse por política apresentam valorizações com números muito semelhantes entre si. Já os que possuem pouco ou nenhum interesse por política apresentam médias bem mais baixas do que os demais. 
Gráfico 6 - Estudantes. Interesse por política x fatores de mudança no passado

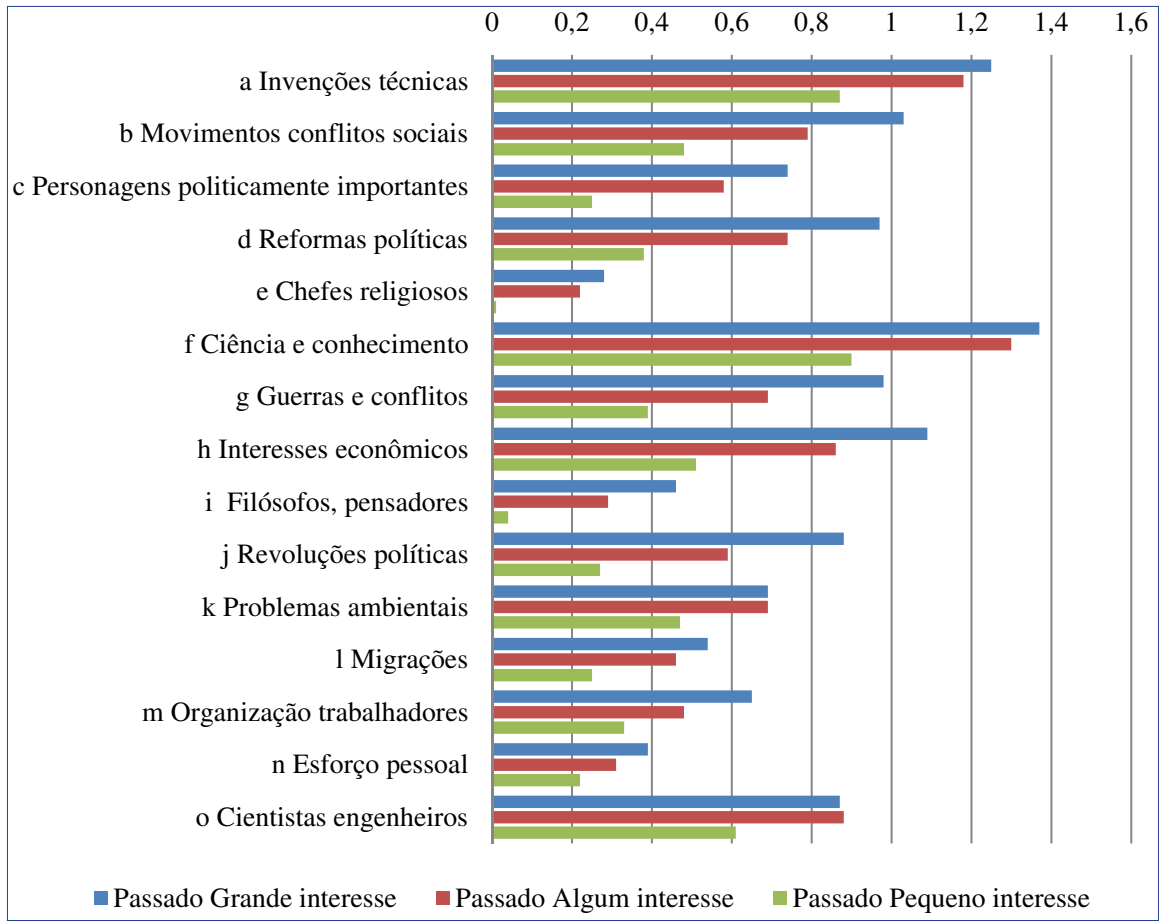

Fonte: Projeto Jovens e a História. 2013.

Os valores para passado e para futuro não se alteram significativamente, mas se nota o mesmo movimento entre os estudantes que afirmam ter pequeno ou nenhum interesse por política: as médias são bem menores do que os que afirmam ter grande ou algum interesse.

De maneira geral, todos seguem a média, mas os estudantes que têm grande ou algum interesse por política são mais incisivos em sua avaliação do que os que não possuem interesse. Seria importante fazer cruzamentos com todas as perguntas, para ver se é uma tendência. Além disso, poderse-ia tentar localizar quem são os jovens que afirmam não possuir interesse por política. Em quais escolas se concentram? Quais são seus conteúdos favoritos? Qual seu posicionamento sobre temas sensíveis? Apesar da dificuldade de refletir sobre convicções políticas entre pessoas tão jovens, esse pode ser um indício importante para a reflexão de professores de História. 
Gráfico 7 - Estudantes. Interesse por política x fatores de mudança no passado

$$
\begin{array}{lllllllllll}
-0,4 & -0,2 & 0 & 0,2 & 0,4 & 0,6 & 0,8 & 1 & 1,2 & 1,4 & 1,6
\end{array}
$$

b Movimentos conflitos sociais

c Personagens politicamente importantes

d Reformas políticas

e Chefes religiosos

f Ciência e conhecimento

g Guerras e conflitos

h Interesses econômicos

i Filósofos, pensadores

j Revoluções políticas

$\mathrm{k}$ Problemas ambientais

1 Migrações

m Organização trabalhadores

$\mathrm{n}$ Esforço pessoal

o Cientistas engenheiros

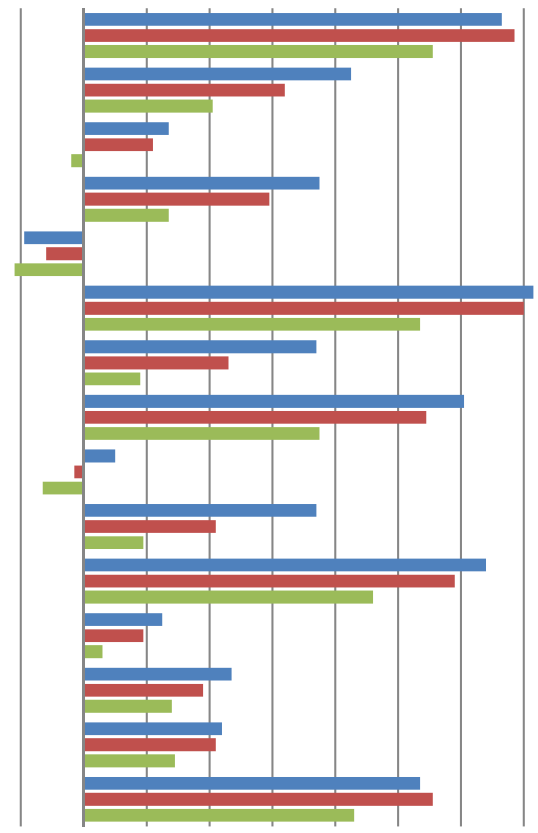

$\square$ Futuro Grande interesse $\quad$ Futuro Algum interesse $\quad$ Futuro Pequeno interesse

Fonte: Projeto Jovens e a História. 2013.

\section{SOBRE A AGÊNCIA HISTÓRICA E OS SENTIDOS HISTÓRICOS}

O conjunto de dados apresentados neste texto permite concluir que os fatores favoritos de mudança variam pouco em relação a passado-futuro, ao país, em relação a professores e alunos e às escolhas políticas ou eleitorais. O que muda é a intensidade com que se valoriza ou não cada fator. Professores e estudantes se afastam, também, na relevância que atribuem aos interesses econômicos, e os docentes se afastam mais da neutralidade do que os estudantes. Quando se comparam países, as mesmas tendências, nas respostas, são visíveis entre docentes e estudantes.

As razões mais frequentes destacadas por todos são as relacionadas com inovação científica e tecnologia e, em segundo lugar, as de ordem coletiva e econômica. Não é possível relacionar essa tendência com alguma corrente historiográfica contemporânea, nem em currículo. Embora a 
questão tecnológica esteja presente na literatura sobre ensino de História, não aparece no sentido aqui detectado.

\section{CONSIDERAÇÕES FINAIS}

Considerando que, de maneira geral, predomina no Brasil o que se costuma chamar de currículo editado (ESCOLANO, 2006 apud CAIMI, 2016), valeria a pena uma investigação aprofundada sobre os principais fatores de mudança descritos nos livros didáticos. Isto poderia ajudar a concluir se a homogeneidade nas respostas reflete tanto uma tendência que circula na sociedade em geral (hipótese), quanto uma tendência presente na história escolar editada, já que, certamente, não reflete uma escola historiográfica. Uma evidência desta afirmação é a baixa circulação da história ambiental, mesmo entre historiadores profissionais (PÁDUA, 2010), contraposta com a alta valorização do tema nas respostas de estudantes e de professores.

Embora à primeira vista se note continuidade nas respostas de estudantes e docentes sobre a conjuntura dos últimos 40 anos e na projeção dos próximos 40 anos, algumas questões parecem se destacar, como o crescimento da valorização do fator Problemas ambientais ou Poluição e o não reconhecimento da migração ou de lideranças religiosas como fatores influentes.

Segundo Rüsen (2015, p. 38), as pessoas percebem a história como "contingência como experiência do tempo", também "perturbação e supressão de sentido" (RÜSEN, 2015, p. 39), além de "humanização do tempo" ou "passagem do tempo natural ao tempo humano" (RÜSEN, 2015, p. 40). Esta passagem permite que contingência e perturbações ganhem sentido, pelo trabalho de interpretação.

É dessa maneira, nesse modo específico do trabalho interpretativo do espírito humano acerca das circunstâncias da vida de seus sujeitos, que a história entra no mundo. Ela não nasce do espírito humano; no entanto, só ganha seu caráter específico mediante seu trabalho com as experiências temporais que a pressionam (RÜSEN, 2015, p. 41).

As constatações aqui apresentadas exigem maior número de conexões entre os dados do projeto, ampliação de pesquisas qualitativas paralelas e maior apoio a teorias sobre explicações históricas e suas construções por parte dos jovens. As reflexões de Rüsen (2007) sobre os limites das 
explicações de tipo nomológico e intencional e as características das explicações de tipo narrativo são importantes, mas só poderiam apoiar se os dados utilizados fossem narrativos e não múltipla escolha. Quiçá a articulação entre o mapeamento dessas tendências e a análise de narrativas escritas seja um passo metodológico interessante a contribuir com o entendimento da construção de narrativas históricas por parte dos jovens.

Entretanto, é possível perceber que alguns tópicos são recorrentes, tanto entre professores quanto entre estudantes, na tentativa de atribuição de sentido à experiência da passagem do tempo e, notadamente, das mudanças sofridas.

Sentido se refere, de um lado, à sensibilidade do homem como porta de entrada da experiência, como entrelaçamento do espírito humano com o mundo em que se encontra; de outro lado, o sentido integra essa experiência do mundo no horizonte da determinação intelectual do agir e do sofrimento humanos. No íntimo do homem, sentido é o critério fundamental, com o qual o homem tanto regula sua relação para consigo mesmo e para com os outros, quanto decide sobre suas intenções e sobre a intencionalidade de sua vontade. Sentido torna possível a orientação. Ele situa a vida humana no horizonte das interpretações; torna o homem e o mundo compreensíveis; possui uma função explicativa; forma a subjetividade humana no construto coerente de um 'eu' (pessoal e social); torna o sofrimento suportável e fomenta o agir pelas intenções. Enfim, o sentido torna possível a comunicação como processo do entendimento intra-humano (RÜSEN, 2015, p. 42).

O sentido de tempo é importante quando se pensa que os sentidos que interessam aqui são os históricos, os temporais. Localizar os eventos no tempo é fundamental para a interpretação e, por sua vez, pode ter implicações diretas na constituição de identidades e na orientação para a ação humana. Ou seja, quando esses jovens e seus professores hierarquizam essas causas de mudança, constroem, também, balizas ao redor das quais deslizam possibilidades de agência histórica para si próprios e seus grupos.

Rüsen explica que a experiência histórica consiste no sofrer e agir dentro das mudanças temporais. A experiência de ruptura causa desequilíbrio, ou carência de orientação, a qual pode ser superada - ou interpretada - no encadeamento das mudanças. Ela tem um caráter desequilibrador e, em razão disso, pode orientar, no campo da cultura, a vida prática, por 
meio da problematização constante das identidades: "[...] a orientação possui uma relação direta com a vida prática [...] É aqui que o saber histórico tem uma das suas mais importantes funções de orientação: seu papel na formação, negociação, implementação e alteração de identidade" (RÜSEN, 2017, p. 47-48).

Tendo em vista que as identidades se constituem e se questionam, constantemente, pelos desequilíbrios temporais e pela relação dialética com os outros, a busca de sentido e de orientação pode motivar para a ação. É nesse aspecto da orientação cultural, temporal e identitária perante os desequilíbrios causados pela experiência da vida prática que Rüsen (2015) encontra indícios das funções práticas do saber histórico.

Assim, pode-se afirmar que a ponte que se lança entre as diferentes experiências de tempo é a História, que se expressa em forma de narração, é a forma humana de conferir sentido a eventos, desde que seja considerada sua temporalidade. A História sempre se narra em contextos sociais e tem caráter de comunicação. Sua utilidade, isto é, o quanto contribui para a orientação e, consequentemente, para a agência histórica, depende sempre desses contextos. Além disso, a tensão entre contingência e liberdade é elemento muito importante para o sentido, o que permite a conexão aqui estabelecida entre as opções e tendências políticas de estudantes e professores e os fatores de mudança que avaliaram.

A existência de uma continuidade nos fatores demonstra que os jovens e os professores localizam-se no tempo de uma forma muito semelhante, havendo coincidências na comparação entre os países. As expectativas de futuro desenham-se de forma interessante na comparação entre o que os estudantes projetam para suas vidas e para o conjunto do país. Nota-se coerência porque, embora projetem para si próprios uma boa vida, ao mesmo tempo em que constatam problemas em seu país, os estudantes mais pessimistas no panorama nacional são, também, os mais pessimistas no panorama individual, e acreditam muito pouco no esforço pessoal como fator de mudança. Com relação ao esforço pessoal, seria de se esperar que fosse um fator menos valorizado pelos docentes, tendo em vista sua tendência à esquerda? Ou será que, novamente, a identidade de professor e as questões educacionais e formativas suplantam o político e o historiográfico? 
Chama a atenção, ainda, a quase insignificante variação de posicionamento dos docentes de distintas convicções políticas, enquanto, entre os jovens, maior ou menor interesse por política implica em diferenças na valorização dos fatores de mudança. É difícil afirmar um significado para esta constatação. No mínimo, é preciso pesquisar mais sobre o assunto, mas, de certa forma, confirma-se algo que professores de História intuem por conta própria, ao observar seus próprios estudantes.

Por fim, são apenas parciais e intuitivas as ideias que se podem forjar sobre agência histórica dos jovens a partir das evidências oferecidas pelo questionário do Jovens e a História, tendo em vista que ele só permite constatar um lado da constituição de sentido, deixando em segundo plano as decisões tomadas pelos jovens ao se reapropriarem do do curso da vida, como afirma Rüsen (2015, p. 55):

$\mathrm{Na}$ atividade de constituição de sentido pela consciência histórica estão presentes dois elementos: um momento constitutivo do sofrer - as coisas do mundo próprio não acontecem como deveriam - e, simultaneamente, um momento constitutivo da liberdade - eu me reaproprio das coisas do meu mundo, interpretativamente e por meio do leme da significância previamente dada, de modo a poder controlar o curso da minha vida segundo critérios que valham como meus (RÜSEN, 2015, p. 55).

Nem estudantes, nem professores, independentemente de onde vivem ou como se posicionam politicamente, consideram que os movimentos sociais, as ações de trabalhadores, as revoluções, os políticos, os líderes ou o esforço pessoal sejam fatores fundamentais de mudança. É possível que tal compreensão reflita tanto elementos da cultura histórica quanto tendência na História ensinada. É difícil saber.

Entretanto, esta constatação indica a necessidade de se prestar mais atenção na forma como as narrativas históricas e os fatores de mudança têm sido expressos no conhecimento histórico escolar veiculado nas aulas de História e construído por estudantes e professores. Haverá implicações pedagógicas derivadas dessa constatação? Ao que parece, a expressão corrente de que os jovens não se enxergam como sujeitos da história corresponde, também, aos docentes. Se a teorização de Rüsen sobre consciência 
histórica está adequada, então, poder-se-ia tensionar o ensino de História nas escolas de maneira estimular a orientação para a ação?

Assim como percebido em diversas outras perspectivas sobre o ensino de História, a ideia é deslocar o centro da aula de História da transmissão de conteúdos para o pensar historicamente e, neste, dedicar-se mais aos elementos finais em que o cognitivo, o ético e o estético conjugam-se para construir novas narrativas. Pode-se pensar em um esforço maior, por parte dos docentes e dos materiais didáticos, em retomar as problematizações iniciais, que mobilizaram o pensamento histórico, e construir situações didáticas em que os estudantes não apenas teorizem, mas tenham de extrapolar seus conhecimentos para situações de tomada de decisões e de proposições diversas.

Outra implicação pedagógica dessas constatações diz respeito à maneira como os textos didáticos explicam as mudanças acontecidas. Quem são os sujeitos que se apresentam como atores das mudanças? Os textos demonstram as possibilidades que foram ensaiadas, mas que, por diversas razões, foram sufocadas ou se desmobilizaram pelo caminho? As mudanças são apresentadas de maneira teleológicas? Entes como $a$ primeira guerra mundial ou a questão militar são mostrados como agentes de mudança? Evidentemente, diversos trabalhos já exploraram as falhas de livros didáticos nesse sentido. Entretanto, aqui se trata não apenas de verificar incorreções historiográficas ou pedagógicas, mas de construir narrativas históricas, na escola, que estejam atentas à orientação para a ação.

A partir deste recorte de pesquisa, fica o convite de seguirmos o debate sobre aulas de História que possibilitem analisar as muitas maneiras pelas quais as mudanças aconteceram e as diversas formas de explicá-las, bem como as implicações desses saberes sobre os questionamentos do presente e os dilemas que atravessamos ou pelos quais somos interpelados.

\section{REFERÊNCIAS}

BAROM, Wilian C.C. Integração latino-americana e consciência histórica: a noção de pertencimento latino-americano de jovens brasileiros no ano de 2013. 2017. 253f. Tese (Doutorado em Educação). Programa de Pós-Graduação 
em Educação. Universidade Estadual de Ponta Grossa. Ponta Grossa, 2017. Disponível em: <http://bicen-tede.uepg.br/tde_busca/arquivo. php?codArquivo=1780 > Acesso em: 15 jul. 2017.

CAIMI, Flavia E. A história na Base Nacional Comum Curricular: pluralismo de ideias ou guerra de narrativas? Revista do Lhiste. Porto Alegre, n.4, v.3, p.86-92, jan./jun. 2016. Disponível em: <seer.ufrgs.br/index.php/ revistadolhiste/article/download/65515/39462> Acesso em: 18 abr. 2017. CERRI, Luis Fernando. Dados quantitativos na reflexão didática de estudantes e professores de História. Revista História Hoje, São Paulo, v.5, n.10, p.138-158, 2016. Disponível em: <https://rhhj.anpuh.org/RHHJ/ article/view/272> Acesso em: 15 jul. 2017.

PACIEVITCH, Caroline. Responsabilidade docente: utopias de professores de história. Curitiba: Appris, 2014.

PÁDUA, José Augusto. As bases teóricas da história ambiental. Estudos Avançados. São Paulo, v.24, n.68, 2010. Disponível em: <http://www. scielo.br/scielo.php?pid=S0103-40142010000100009\&script $=$ sci_ arttext\&tlng=es> Acesso em: 18 abr. 2017.

PAIM, Elison Antonio. Memórias e experiências do fazer-se professor. 2005. 532 f. Tese (Doutorado em Educação) - Universidade Estadual de Campinas, Campinas, 2005. Disponível em: <http://libdigi.unicamp.br/ document $/$ ?code=vtls000379547>. Acesso em: 23 fev. 2012.

RÜSEN, Jörn. Teoria da História: uma teoria da história como ciência. Curitiba: Editora UFPR, 2015.

RÜSEN, Jörn. História viva. Teoria da História III: formas e funções do conhecimento histórico. Brasília: Editora da Universidade de Brasília, 2007. SOARES, Olavo Pereira. A atividade de Ensino de História: processo de formação de professores e alunos. Araraquara, SP: Junqueira \& Marin, 2008. 


\section{REPRESENTAÇÕES DE ESTUDANTES SOBRE HERÓIS NACIONAIS: HISTÓRIAS CONECTADAS DE ARGENTINA, BRASIL, CHILE E URUGUAI}

Flávia Eloisa Caimi

Letícia Mistura

Na mitologia grega, heróis são tidos como semideuses, personagens situados em uma posição intermediária entre os homens e os deuses, cujos poderes eram superiores aos dos humanos em força e inteligência, embora não possuíssem a prerrogativa da imortalidade. A palavra provém do latim heros, e aos poucos foi sendo adotada para designar, nas sociedades ocidentais, o homem ilustre, famoso por suas façanhas e virtudes, que leva a cabo uma ação heroica em prol da coletividade.

A figura do herói, ao longo dos séculos, foi se plasmando nos textos de poetas, cronistas e historiadores, nos manuais escolares, em museus, monumentos, estatuária, toponímia, edificações, coleções arqueológicas e históricas, de acordo com as circunstâncias políticas e sociais de cada época e de cada sociedade. A história escolar se constituiu como o locus privilegiado para a disseminação de uma dada cultura histórica, fortemente vinculada às chamadas memórias de bronze, ao fortalecimento do sentimento patriótico e à construção da nação. No Brasil, a obra de José Veríssimo (1985), intitulada A Educação Nacional, é exemplar para se compreender o papel do ensino de História na construção da nacionalidade. Publicado no Pará em 1890 e reeditado no Rio de Janeiro em 1906, o livro reflete a visão de um autor preocupado com a educação e com os problemas pedagógicos da sua época. Como se vê, a obra é escrita um ano após a proclamação da República e reeditada no momento em que se discutia a chamada Nova República, momentos efervescentes da política nacional.

José Veríssimo era um homem do seu tempo, bastante interessado nas experiências educacionais de países como Estados Unidos, França, Alemanha, Inglaterra, Portugal, mas estava de costas para as nações latino-americanas. Ao tratar da história pátria e da educação nacional, o autor 
exalta as estratégias formativas adotadas pelas nações que considera mais adiantadas, nestes termos:

Nações há - e notarei que são as mais adiantadas e progressivas ciosíssimas do seu passado e tradições e de todos os monumentos que os relembram e perpetuam. Não só desveladamente os conservam e restauram, senão que carinhosamente vão erguendo novos ou rebuscando e esquadrinhando antigos, com que engrossam os seus tesouros de recordações pátrias, num tocante sentimento de amor dessas recordações. São agora inúmeros os museus e coleções que, templos do patriotismo, encerram as relíquias do passado nacional. Juntai a isso as inscrições lapidares consagrando o nascimento, a morte ou a simples passagem de um falecido compatriota ilustre, as estátuas, monumentos funerários e memórias diversas, com que esses povos diariamente consagram, para imortalidade e para a glória, aqueles que os ilustraram ou que os serviram algum feito que os afama e glorifica, e tereis uma constante, eloquente e sugestiva lição de história nacional (VERÍSSIMO, 1985, p. 102).

Nas sociedades contemporâneas, com interesses diversos e projetos distintos, elaboram-se diferentes (e coexistentes) versões do passado, protagonizadas por muitas vozes, representadas pela Igreja, pela Escola, pelo Exército, pela Imprensa, pelo Estado, pela língua nacional, pela história pátria, pelos rituais cívicos, dentre tantos outros agentes e linhas de força. Para este autor, também para muitos autores das gerações subsequentes, a escola tem um papel estratégico e decisivo na construção de um sentido comum do passado para o fortalecimento de uma dada identidade nacional, de modo a afiançar a soberania da nação. É um lugar privilegiado, na medida em que congrega gerações de crianças e jovens e, por meio de seus agentes, práticas, normas e rituais, apresenta-lhes certa seleção e combinação dessas diferentes vozes/ideias, que permite criar um sentido comum do que significa ser argentino, brasileiro, chileno ou uruguaio.

É forçoso reconhecer, no entanto, que a escola é uma instituição complexa, dificilmente redutível a um só formato ou a uma fórmula única. Os atores da instituição escolar são muitos, diversos, distintos, heterogêneos, e em suas práticas manifestam-se tanto divergências quanto convergências. Ademais, a esses atores incorporam-se mensagens provenientes de outras fontes, como as já mencionadas. Romero (2004) provoca-nos a pensar acerca dos efeitos da escolarização sobre as consciências dos estudantes, 
com essa instigante pergunta: o que fica no fundo da nossa consciência quando esquecemos os conteúdos específicos que a escola nos ensinou? Afirma o autor que as imagens que permanecem parecem naturais, mas não são naturais nem são neutras. Elas têm maior capacidade de operar quanto mais ocultas estejam, diante de qualquer exame crítico. Sem que nos demos conta, essas imagens guiam nossos juízos e nossas ações, constituem nosso sentido comum. Na mesma direção, Kusnick e Cerri (2014), alertam que o viés conteudista que tem predominado nas práticas de ensinar e aprender a história escolar não se mostra capaz de atingir os núcleos de sentido mais profundos nas concepções dos estudantes, nem tampouco de lhes oferecer subsídios para fazer uma leitura de mundo emancipatória.

Diante de tais pressupostos, o texto está consubstanciado no propósito de analisar os efeitos da cultura histórica sobre o pensamento de jovens na faixa etária de 15-16 anos que frequentam a escola secundária na Argentina, Brasil, Chile e Uruguai, notadamente no que diz respeito às suas representações sociais acerca dos heróis nacionais. Trata-se de buscar compreender as interpretações que os estudantes fazem do passado, considerando as representações sociais como lugar de confluência entre as práticas socioculturais, a memória coletiva e as suas identidades sociais.

O estudo aqui apresentado comporta a análise comparativa de quatro textos produzidos no âmbito do projeto internacional-interinstitucional Jovens e a História no Mercosul ${ }^{1}$, cada um deles representativo de um país envolvido na amostra - Argentina, Brasil, Chile, Uruguai -, excetuando-se apenas o Paraguai. Todos os textos estão circunscritos ao mesmo objeto, que é investigar o pensamento histórico dos jovens no que concerne às suas representações sociais sobre heróis nacionais, adotam o mesmo instrumento de produção e análise de dados, partilham de referenciais teóricos muito próximos, que serão detalhados adiante.

O tratamento do conjunto dos dados da pesquisa está amparado no conceito de histórias conectadas, segundo os estudos de Gruzinski (2003), Prado (2005), Vidal e Ascolani (2009), relacionando-se a uma definição inicialmente proposta pelo historiador indiano Sanjay Subrahmanyam, ao

\footnotetext{
${ }^{1}$ A descrição e a caracterização do Projeto constam da Apresentação deste livro.
} 
analisar a visão da historiografia europeia sobre o mundo asiático, mais especificamente a que trata do império português. A relevância de buscar as conexões das representações sociais de jovens secundaristas acerca dos heróis nacionais de Argentina, Brasil, Chile e Uruguai está direcionada às possibilidades de apreender a relação dialética entre os níveis global e local, as particularidades e o modo de articulação das tendências globais, distinguindo o que é próprio, específico, singular de um sistema e o que se manifesta como tendência mais geral, sem tratá-lo como objeto isolado, separado daquilo que lhe dá significado. Outro cuidado implicado na abordagem das histórias conectadas é o de evitar que se estabeleçam cisões polarizadas entre os objetos sob análise e, com isso, tratá-los a partir de relações de proeminência e subordinação (PRADO, 2005).

Serge Gruzinski (2003, p. 323) defende como uma das tarefas do historiador a de exumação das ligações históricas, uma vez que as histórias são múltiplas e não existe "uma História única e unificada, com ' $\mathrm{H}$ ' maiúsculo". Ainda, afirma o autor, deve-se considerar que essas histórias estão ligadas e comunicam-se entre si, razão pela qual "o historiador tem de se converter numa espécie de eletricista encarregado de restabelecer as conexões internacionais e intercontinentais que as historiografias nacionais e as histórias culturais desligaram ou esconderam, entaipando as suas respectivas fronteiras" (GRUZINSKI, 2003, p. 323).

Esta metáfora do eletricista é interessante, mas guarda o perigo de nos enredar em uma tendência de homogeneização das histórias dos países latino-americanos, pela semelhança de alguns de seus processos históricos como, por exemplo, "a colonização ibérica, a independência política, a formação dos Estados Nacionais, a preeminência inglesa e depois a norte-americana", dentre outros (PRADO, 2005, p. 12). De outra parte, é difícil sustentar a ideia de uma originalidade absoluta em cada uma dessas histórias nacionais, uma vez que atravessaram processos sincrônicos e características comuns.

Mediante tais ponderações, acreditamos que, em cada um desses quatro países, existem processos resultantes de trajetórias históricas particulares, mas que estão conectados por laços que articulam uma história 
comum, que pode ser pensada e estudada dentro de uma dinâmica que é, em grande medida, compartilhada. Este é um enfoque que permite reconhecer diferentes pontos de vista a partir de um mesmo mirante, e admite a coexistência de diferentes histórias em um mesmo contexto espacial e temporal. Assim, o olhar que estendemos para essas histórias conectadas está sustentado no esforço de ressaltar as simetrias e discrepâncias contextualizadas em suas particularidades e, ao mesmo tempo, em localizar pontos de contato, identificar sentidos de unidade, e construir perspectivas de continuidade entre os países que integram o estudo.

Como anteriormente anunciado, focalizaremos a análise sobre quatro estudos que debruçam sua atenção em uma questão específica do questionário padronizado, a de número 33, que solicita aos estudantes escreverem o nome de três heróis que considerem importantes para o seu país, em ordem descrescente e hierárquica. Estas respostas foram registradas em letra de forma (tipo bastão), o que favoreceu a leitura dos arquivos escaneados do questionário por um software de reconhecimento de caracteres e marcas, gerando uma linha de planilha para cada questionário respondido.

Três dos quatro estudos em análise - Argentina, Brasil e Chile serviram-se do software Evoc 2000, utilizado no processamento dos dados gerados pelas colunas referentes à hierarquização de heróis/respostas (herói 1, herói 2, herói 3). O software foi criado por Pierre Vergès, com base do conceito de núcleo central, vinculado à Teoria das Representações Sociais, que orientou os mesmos estudos acerca da estratégia de produção e análise dos dados empíricos, como veremos a seguir. O software Evoc opera com a construção de duas variáveis: frequência da menção de determinado nome e sua ordem média de evocação, ou seja, a posição média em que ele aparece quando os nomes são citados. Por exemplo, um nome que aparecesse em primeiro lugar em todas as evocações teria uma ordem média de evocação igual a um $(\mathrm{OME}=1)$, e outro que sempre aparecesse em terceiro lugar, teria OME igual a três. Assim, quanto menor a OME, mais prontamente e mais prioritariamente o nome foi lembrado/evocado. Nomes que apresentam uma grande frequência e uma baixa OME são aqueles que muito provavelmente pertencem ao núcleo central da representação social. Nomes com alta 
frequência, mas alta OME, assim como nomes com baixa frequência, mas baixa OME, figuram nas zonas intermediárias, enquanto nomes com baixa frequência e alta OME são localizados no núcleo periférico. O tratamento dos dados empíricos do Uruguai consubstanciou-se pela análise da frequência e porcentagem das menções, cotejando os dados hierarquicamente, elaborando um ranking de heróis escolarizados e individualmente (por herói/ estudante), buscando padrões ou regularidades de respostas.

Os estudos mobilizaram um montante de 3312 respondentes que preencheram pelo menos uma das lacunas de forma legível, totalizando 8404 evocações/menções - de 9936 possíveis, o que significa que 1532 lacunas permaneceram em branco, caracterizando-se como fator importante de análise em todos os estudos. Ao mesmo tempo, mais de 8 mil evocações de heróis foram registradas por jovens de 15 a 16 anos. Embora a amostra que aqui expomos e analisamos guarde grandes disparidades, como o número assimétrico de respondentes entre os países ${ }^{2}$ e a sua dispersão geográfica interna a cada nação, acreditamos na exemplaridade das interpretações possíveis pelo material empírico, na medida em que permitem uma aproximação do mundo de significados construído pelos estudantes a respeito de uma representação específica, o herói nacional, que se consistiu em categoria de análise dos estudos dos quatro países.

\section{SOBRE A CATEGORIA CENTRAL DE ANÁLISE: REPRESENTAÇÕES SOCIAIS DE HERÓIS NACIONAIS}

O que significa pensar em herói como uma categoria de análise? Sobretudo, implica tomá-lo como ente de significados e compreender o seu próprio processo histórico de constituição, como tal, no imaginário ocidental. Anne-Marie Thiesse (2001/2002), ao descrever o processo de construção das identidades nacionais dos Estados-Nação europeus no século XIX, cria uma espécie de check-list identitária, cuja matriz de constituição da nacionalidade envolve a inventariação de um passado comum, elevado

\footnotetext{
${ }^{2}$ Contabilizamos 965 respondentes na amostra da Argentina; 1937 respondentes na amostra do Brasil; 182 respondentes na amostra do Chile; e 228 respondentes na amostra do Uruguai. Estes números referem-se aos participantes que escreveram pelo menos um nome entre os três espaços reservados.
} 
a patrimônio coletivo, e destaca o enorme esforço pedagógico requerido na elaboração de novas identidades coletivas, como no caso da formação dos Estados Nacionais analisados em seus estudos. A autora traz uma perspectiva interessante, já que aborda o momento de gestação da própria ideia de nação, um contexto de mudança radical, muito mais do que de cartografia ou limites políticos, de representações.

De acordo com Thiesse (2001/2002, p. 8), uma nação que se pretenda "comunidade de nascimento", inscrevendo "igualdade e fraternidade de princípio entre seus membros", deve se estabelecer em termos de ancestrais fundadores, com uma narrativa histórica que perpetue a ideia de continuidade, a despeito dos conflitos que a precederam. Isto inclui uma galeria de heróis, uma língua nacional e elementos simbólico-imagéticos, materiais ou imateriais em que a nação esteja inscrita, como monumentos, artes plásticas em geral, folclore, etc. Acompanhando os processos de construção dos Estados-Nação europeus, como a Inglaterra, a França e a Alemanha, é possível visualizar com clareza esta lista operando como uma matriz de construção representacional do nacionalismo. Thiesse (2001/2002) visualiza, nessa padronização, mais do que uma limitação entre o que é o específico no universal (a função principal do construto da identidade nacional), a exposição do êxito e do potencial de generalização legado por esta revolução de representações, que supera as esferas monárquicas e militares. Elas "não são percebidas como o produto de uma reconfiguração homogeneizante das diferenças, mas como formações sui generis perfeitamente autônomas" (THIESSE, 2001/2002, p. 13), afirmando-se em uma atemporalidade forjada, pressuposta.

José Murilo de Carvalho (1998) recupera um movimento muito semelhante, ao construir um quadro da elaboração do imaginário popular no processo de legimitação do sistema republicano brasileiro, gestado em uma conjuntura de disputas ideológicas e políticas, e mais ainda, de simbologias e alegorias. Ao menos três grandes correntes ideológico-discursivas, o liberalismo à americana, o jacobinismo à francesa e o positivismo procuraram projetar, em diversas tentativas e incursões, os delineios de uma imagem do novo regime, "cuja finalidade era atingir o imaginário popular e recriá-lo dentro dos valores republicanos" (CARVALHO, 1998, p. 
9-10). Segundo este autor, para além da legitimação política, novos regimes necessitam de adesão afetiva, pois era preciso operacionalizar símbolos universais, facilmente reconhecíveis, em que os discursos encontrassem morada. Nesses símbolos, forjados como poderosos instrumentos de adesão, estariam inscritos os elementos que compunham a nação e, especialmente, os que encontrassem uma correspondência na comunidade de sentido (ou imaginação) preexistente no imaginário popular. Se esta correspondência inexistisse, a relação de significado não se estabeleceria, e o símbolo cairia no esquecimento.

Neste processo, a criação de um herói-símbolo é, segundo Carvalho (1998, p. 55), um instrumento eficaz de legitimação, já que pode ser facilmente relacionado e impresso no imaginário popular: heróis são “[...] encarnações de ideias e aspirações, pontos de referência, fulcros de identificação coletiva”. É onde se aporta o processo de heroificação, segundo o autor, na transmutação da figura real, humana, a fim de torná-la um arquétipo a serviço de uma coletividade de valores. A construção de um herói requer grande e trabalhoso investimento, já que é preciso, ao mesmo tempo, produzir uma figura que contenha em si uma potência de mobilização afetiva e de ideais coletivos, também que corresponda a um modelo ético, moral e ideológico idealizado tanto pelo regime político quanto pela população. O apelo do herói, de acordo com o autor, precisa ser o de totem cívico, operando pela unidade de diferentes, pelo universalismo. Assim foi o herói consagrado pela República brasileira, Tiradentes, cujo apelo acabou por unir em representação as três vertentes republicanas que disputavam por supremacia discursiva. O herói acabou por tornar-se símbolo nacional, não apenas republicano.

No início deste texto mencionamos a criação de heróis pelas sociedades ocidentais. Até então, enfatizamos seu importante papel na construção da nacionalidade e na legimitação de regimes políticos. No entanto, e como nos lembra Anne-Marie Thiesse (2001/2002), é impensável separamos desses processos o esforço depreendido pela esfera pedagógico-escolar, na tarefa de constantemente elaborar, transmitir e legitimar as narrativas do passado vinculadas à memória pátria e à história oficial da nação. De 
forma especial e com espaço curricular privilegiado, a disciplina de História tem sido a principal disseminadora desse empreendimento pedagógico, tal como anunciava José Veríssimo (1985). À história escolar delegou-se, por muito tempo, estritamente esta função, aportada pelo próprio conhecimento disciplinar.

Como sabemos, a grande crise epistemológica enfrentada pela História como disciplina, a partir principalmente de meados do século XX, veio a questionar, também, a história escolar, como anunciado por Mario Carretero (2010), colocando em xeque o perigoso narcisismo dos relatos históricos da nação (a nossa nação). Eles carregam consigo fragilidades no que tange à construção da alteridade e o respeito ao outro, o não-nosso, o diferente. Nesse caso, as histórias que compunham o modelo histórico-pedagógico, as grandes epopeias da pátria, mais desagregam do que unificam grupos, sejam sociais, culturais ou religiosos, e populações. A história escolar entra em disputa com outras representações, provenientes de narrativas e relatos advindos das produções culturais e midiáticas, da história da família, das práticas cotidianas, dos diferentes pertencimentos religiosos, etc. Quando não possui arsenal inclusivo destas representações (e muitas vezes colocando-se em conflito com elas) em sua matriz disciplinar, a história escolar fragiliza-se diante dos jovens estudantes, permanecendo incapaz de lhes ajudar na construção de suas identidades, de seu futuro. Ao disseminar um relato canônico inquestionável, a história escolar oportuniza a construção de apenas uma memória histórica ou coletiva, de uma versão da história, viabilizando a formação de representações sociais igualmente limitadoras.

Junto da proposta de visualização de heróis como evocações das representações possibilitadas pelo saber histórico escolar, os quatro estudos que ora analisamos procuram compreender as menções do grupo de estudantes, participantes do projeto, tanto em relação às suas interpretações pessoais da realidade, como indivíduos produtores de conhecimento, quanto em relação à sua participação em uma comunidade cultural, que implica na inserção em uma cultura histórica e na formação da consciência histórica. Esta premissa ajuda-nos a traçar os alicerces teórico-conceituais dos estudos, que compartilham algumas semelhanças: os quatro mobilizam 
sua análise por meio dos conceitos de cultura histórica, consciência história e representações sociais (ou imaginários coletivos).

\section{CULTURA HISTÓRICA, CONSCIÊNCIA HISTÓRICA E REPRESENTAÇÕES SOCIAIS}

Nos estudos aqui analisados, entende-se cultura histórica como o conjunto organizado de referenciais imagéticos, ideias, valores, conhecimentos e atitudes, que são a expressão visível e viva da consciência histórica (RÜSEN, 1994, 2001, 2007, 2009). A cultura histórica é exercida na e pela consciência histórica, fornecendo orientação temporal aos indivíduos para a vida prática e para a compreensão de si mesmos. Segundo Rüsen (2009), a cultura histórica, como todas as demais culturas, é multidimensional e contém expressões morais, pedagógicas, políticas e retóricas. Este autor distingue três dimensões básicas da cultura histórica, que são responsáveis por distintos critérios de sentido: 1) uma dimensão política, que diz respeito à legitimação de certa ordem política e a relações de poder; 2) uma dimensão estética, "relacionada com a eficácia psicológica das interpretações históricas, ou com a parte de seus conteúdos que afetam os sentidos humanos" (RÜSEN, 2009, p. 172); e 3) uma dimensão cognitiva, que se expressa nos eventos passados significativos para o presente e seu futuro, na qual concorre fundamentalmente o aspecto do conhecimento. Pode-se concluir, então, que a cultura histórica refere-se ao conjunto de operações da memória histórica e da consciência histórica, que se efetivam em determinado contexto social. Neste sentido, é na cultura histórica que se encontra a articulação prática e operante da consciência histórica em determinada sociedade.

Por sua vez, a consciência histórica pode ser definida como um aspecto inerente da vida mental, pelo qual se procede ao exercício indispensável de atribuir significado ao tempo; ou seja, reconhecer e significar o passado, de modo a orientar as ações presentes, tendo em vista as expectativas do futuro que se almeja. Trata-se de um processo mental de criação de sentido, sem o qual a vida prática se tornaria impossível, uma vez que é pela consciência histórica que o sujeito, seja no plano individual ou coletivo, estabelece determinada relação com o passado e produz uma explicação 
de si mesmo e do mundo, da existência humana e da cultura. Esta produção mental de sentido compreende um todo formado por pontos de vista, representações, compensações e projeções, que estão na base das tomadas de decisão e de ação sobre o mundo.

A consciência histórica, de acordo com Rüsen (2001), é produzida por meio de uma operação de narrativa histórica (de vida, individual, coletiva, social), da qual nenhum ser humano prescinde, já que vive em constante interpretação da realidade. Por meio desta operação de narrar, o ser humano formula e reformula representações e condições de continuidade da vida, nela instituindo identidade por meio da memória. Neste caso, a narrativa que se produz sobre a experiência do homem no tempo, entendida como história, é produtora e produto, simultaneamente, da consciência histórica. Segundo Rüsen (2001), a consciência histórica abrange quatro diferentes tipos de constituição de sentido, presentes tanto nas narrativas historiográficas, e em suas formas de comunicação, sendo a história escolar uma delas; quanto na elaboração de sentido à vida prática, cotidiana, comum a todos. Estes tipos de constituição de sentido acontecem por meio de operações de significação, envolvendo a memória da compreensão/afirmação das formas de viver e ordenamentos do mundo real e de suas origens (constituição tradicional de sentido); de regularidades/regras gerais do agir (constituição exemplar de sentido); de acontecimentos que questionem ou estabeleçam contraponto à ordem histórica vigente (constituição crítica de sentido); e de transformações a partir do confronto com formas de viver estranhas ou alheias às próprias (constituição genética de sentido). É importante destacar que esta tipologia não impõe ordem, linearidade ou sequencialidade: todas estão presentes no plano de constituição de sentido mental, em menor ou maior grau. Cada tipo é acompanhado por um sentido de tempo, por uma concepção de continuidade, e implica um modo de comunicação e de identidade.

A Teoria das Representações Sociais (TRS), elaborada no final dos anos 1950 e início da década de 1960 por Serge Moscovici (1978), apresenta a preocupação em construir uma psicologia social que apreenda os fenômenos sociais (crenças e ações) em sua gênese construtiva, como resultado de processos psicológicos e sociológicos. Tem como objetivo 
central compreender "como se formam e como funcionam os sistemas de referência que utilizamos para classificar pessoas e grupos e para interpretar os acontecimentos da realidade cotidiana" (ALVES-MAZZOTTI, 1994, p. 60). As representações sociais consistiriam, portanto, em um complexo de significados produzidos coletivamente para dar sentido às experiências cotidianas, originando-se nas interações sociais de que fazem parte os membros de determinado grupo. Tais representações são apropriadas pelos sujeitos em um processo ontogenético, mas se ativam sob a forma de identidades sociais e incidem como base, tanto comportamental quanto de tomadas de decisão e de posição dos indivíduos.

Visualizando o edifício teórico construído pelos quatro estudos aqui analisados, justificamos e compreendemos seu interesse em focalizar, dentro de um vasto número de importantes questões no questionário aplicado, o material obtido pela questão que solicitava a evocação de heróis pelos jovens estudantes. Tomar o herói como categoria de análise permite enxergar o movimento dinâmico entre as representações sociais, a memória histórica e coletiva, o conhecimento histórico escolar e a cultura histórica, uma vez que resguarda, em um único nome/representação, vestígios de uma realidade cultural, de construção de significados e indícios da força da cultura histórica em ação nos contextos de escolarização.

Ao final dos anos de 1980, Paulo Miceli conduziu um estudo sobre ensino de história e heróis, por meio de uma amostra de dados produzidos a partir de questionários (questões de livre resposta) com 267 estudantes brasileiros dos quatro anos finais do Ensino Fundamental e dos três anos do Ensino Médio, à época denominados primeiro e segundo graus. Caracterizando a escola como um viveiro de heróis, Miceli (1997) destaca o papel instrumental da escolarização dos heróis nas disputas históricas pelas versões do passado e no reforço de uma memória histórica específica. No estudo de Miceli (1997), os heróis que sobressaíram primariamente entre os estudantes foram Dom Pedro I, como prócer da pátria e pai fundador; e Tancredo Neves, político brasileiro, o primeiro presidente eleito pós-Regime Militar, cuja morte prematura contribuiu em sua inscrição, nas representações coletivas, como mártir, símbolo de uma esperança frustada para o progresso do país. O estudo do autor ajuda a compreender 
como uma amostra em análise, mesmo pequena, que envolva o ensino de História e a produção de heróis pela memória histórica, nos aproxima do que Michel De Certeau (1988) entende como a tarefa da operação de análise história: historicizar o atual, conferindo-lhe um lugar próprio e exemplar e, ao recortar dados intencionalmente, abrir uma fenda na coerência entre passado, presente e futuro, evidenciando o que falta a um projeto de futuro. Aqui, abordamos estudos que, ao recortarem uma fatia da realidade da história escolar em relação com a cultura histórica, e seu poder em formular representações coletivas, permite-nos abrir uma fenda para compreendermos o que faz falta nesse cenário.

\section{CONECTANDO AS REPRESENTAÇÕES SOCIAIS SOBRE HERÓIS NACIONAIS ENTRE JOVENS ARGENTINOS, BRASILEIROS, CHILENOS E URUGUAIOS}

Mediante os pressupostos conceituais e metodológicos já anunciados, mobilizamos os esforços no sentido de analisar os resultados da pesquisa realizada nos quatro países, com base nos textos produzidos pelos pesquisadores da Argentina (AGUIRRE; RUIZ, 2017), Brasil (CERRI; CAIMI; MISTURA, 2017), Chile (GONZÁLEZ CALDERÓN; CERRI; ROSSO, 2016) e Uruguai (ALVEZ CAVANNA; QUIRICI, 2017). Considerando que os quatro estudos derivam de uma pesquisa interinstitucional/internacional, cujos aportes teórico-metodológicos são muito semelhantes, observaram-se diversos pontos de conexão entre os seus resultados, ainda que não estejam ausentes as diferenças e as singularidades de cada país.

Dentre os quatro estudos, três deles, Argentina, Brasil e Chile, adotam como instrumental metodológico o Software EVOC 2000, que permite localizar o provável núcleo central e, também, o sistema periférico da representação social. O estudo de Alvez Cavanna e Quirici (2017), ainda que não tenha feito uso desse instrumento, também oferece elementos para situar o núcleo central e o sistema periférico das representações sociais dos jovens estudantes acerca dos heróis nacionais. Para um cotejo dos resultados, apresentamos a Tabela 1 com os dados que compõem o núcleo central das representações dos estudantes de cada um dos quatro países. 
Tabela 1 - Heróis Nacionais presentes no núcleo central das representações sociais

\begin{tabular}{|c|c|c|c|c|c|}
\hline & & $\mathbf{A R}$ & GENTINA & & \\
\hline Frequência $\geq 259$ & 9 e $\mathrm{OME} \leq 2$ & & Frequência $\geq 259$ e $\mathrm{OME} \geq 2$ & & \\
\hline San Martín & 626 & 1,42 & En Blanco & 547 & 2,16 \\
\hline Belgrano & 514 & 1,90 & Sarmiento & 264 & 2,473 \\
\hline Frequência $<259$ & 9 e $\mathrm{OME}<2$ & & Frequência < 259 e OME > 2 & & \\
\hline Cristobal Colón & 23 & 1,73 & Perón & 136 & 2,022 \\
\hline Nadie & 11 & 1,54 & Eva Perón & 101 & 2,08 \\
\hline & & & Maradona & 56 & 2,17 \\
\hline & & & Favaloro & 44 & 2,27 \\
\hline & & & Kirchner & 32 & 2,50 \\
\hline & & & Moreno & 24 & 2,33 \\
\hline & & & Rosas & 22 & 2,59 \\
\hline & & & Messi & 18 & 2,16 \\
\hline & & & Mitre & 17 & 2,70 \\
\hline & & & Roca & 12 & 2,00 \\
\hline & & & RASIL & & \\
\hline Frequência $>=13$ & 34 e $\mathrm{OME}<1,9$ & & Frequência $>=134$ e OME $>=1,9$ & & \\
\hline & & & Lula & 610 & 1,957 \\
\hline $\begin{array}{l}11 \text { iradentes } \\
\text { Vargas }\end{array}$ & $\begin{array}{l}4 / 1 \\
440\end{array}$ & $\begin{array}{l}1,841 \\
1,884\end{array}$ & Nomes do esporte & 389 & 2,100 \\
\hline $\begin{array}{l}\text { vargas } \\
\text { J. Kubitschek }\end{array}$ & $\begin{array}{l}440 \\
413\end{array}$ & $\begin{array}{l}1,884 \\
1,814\end{array}$ & Ressignificação & 303 & 1,993 \\
\hline Cabral & 396 & $\begin{array}{l}1,014 \\
* 1,528\end{array}$ & Irreverência & 216 & 1,977 \\
\hline D. Pedro I & 269 & 1,695 & Princesa Isabel & 186 & 2,016 \\
\hline Religiosos & 165 & 1,784 & Nomes da música & 145 & 2,269 \\
\hline & & & Dilma & 137 & 2,328 \\
\hline Frequência $<134$ & e $\mathrm{OME}<1,9$ & & Frequência $<134$ e OME $>=1,9$ & & \\
\hline D. Pedro II & 120 & 1,883 & Colombo & 197 & 1,938 \\
\hline Carlos Chagas & 19 & 1,684 & Santos Dumont & 126 & 1,921 \\
\hline Chico Mendes & 19 & 1,789 & Zumbi & 94 & 1,979 \\
\hline Zilda Arns & 12 & *1,667 & $\mathrm{FHC}$ & 56 & 2,071 \\
\hline Ant. Conselheiro & 12 & 1,833 & Deodoro da Fonseca & 38 & 2,158 \\
\hline Caxias & 12 & 1,833 & Collor & 25 & 2,120 \\
\hline & & & Machado de Assis & 25 & 2,200 \\
\hline & & & Niemeyer & 25 & 2,240 \\
\hline & & & Joaquim Barbosa & 18 & 2,056 \\
\hline & & & Bento Gonçalves & 16 & 2,125 \\
\hline & & & Rondon & 14 & 2,143 \\
\hline & & & Prestes & 13 & 2,077 \\
\hline & & & Drummond & 11 & 2,091 \\
\hline & & & Hitler & 11 & 2,182 \\
\hline & & & Maria da Penha & 10 & 2,300 \\
\hline & & & Barão de Mauá & 10 & 2,400 \\
\hline & & & Jose de Alencar & 10 & 2,400 \\
\hline
\end{tabular}


conclusão

\begin{tabular}{|c|c|c|c|c|c|}
\hline \multicolumn{6}{|c|}{ CHILE } \\
\hline \multicolumn{3}{|l|}{ Frequência $\geq 36$ e $\mathrm{OME} \leq 1,9$} & \multicolumn{3}{|l|}{ Frequência $\geq 36$ e $\mathrm{OME} \geq 1,9$} \\
\hline Bernardo o'Higgins & 91 & 1,87 & & & \\
\hline Arturo Prat & 72 & 1,87 & Manuel Rodríguez & 54 & 1,96 \\
\hline José Miguel Carrera & 55 & 1,70 & & & \\
\hline \multirow[t]{2}{*}{ Frequência < 36 e OME < 1,9 } & & & \multicolumn{3}{|l|}{ Frequência < 36 e OME > 1,9 } \\
\hline & & & Irreverencia & 22 & 2,14 \\
\hline Salvador Allende & 20 & 1,85 & Cambio significado & 13 & 2,15 \\
\hline Pedro de Valdivia & 13 & 1,53 & Lautaro & 9 & 2,33 \\
\hline \multirow[t]{2}{*}{ Cristóbal Colón } & 10 & 1,60 & Diego de Almagro & 7 & 2,00 \\
\hline & & & Violeta Parra & 7 & 2,42 \\
\hline \multicolumn{6}{|c|}{ URUGUAI } \\
\hline \multirow[t]{2}{*}{ Frequência $>=39$ e $\mathrm{OME}<1,9$} & & & \multicolumn{3}{|l|}{ Frequência $>=39$ e OME $>=1,9$} \\
\hline & & & En Blanco & 160 & 2,263 \\
\hline \multirow[t]{2}{*}{ Artigas } & 151 & 1,172 & Varela & 59 & 2,220 \\
\hline & & & Lavalleja & 39 & 2,385 \\
\hline \multirow[t]{4}{*}{ Frequência $<39$ e OME $<1,9$} & & & \multicolumn{3}{|l|}{ Frequência < 39 e OME > = 1,9 } \\
\hline & & & Rivera & 26 & 2,500 \\
\hline & & & Aparicio Saravia & 18 & 2,167 \\
\hline & & & Ninguno & 18 & 2,000 \\
\hline Forlan & 10 & 1,800 & Oribe & 16 & 2,313 \\
\hline \multirow[t]{4}{*}{ Wilson_Ferreira } & 6 & 1,833 & Batlle & 14 & 2,286 \\
\hline & & & Luis Suarez & 14 & 2,214 \\
\hline & & & Tabare Vazquez & 9 & 2,333 \\
\hline & & & Mujica & 7 & 2,000 \\
\hline
\end{tabular}

Fonte: Sistematização das autoras com base em Aguirre e Ruiz (2017); Cerri, Caimi e Mistura (2017); González Calderón, Cerri e Rosso (2016) e Alvez Cavanna e Quirici (2017).

Recordemos que Abric $(1993 ; 1998 ; 2001)$ aponta, como caraterísticas essenciais do núcleo central das representações sociais, a hierarquia e a estabilidade, e em torno do núcleo central (quadrante superior esquerdo) orbitam as imagens intermediárias e periféricas. As representações que estão em vias de se consolidar como centrais, ou representações outrora centrais que começam a sofrer desgaste, são encontradas em zonas intermediárias das representações (quadrante superior direito e quadrante inferior esquerdo). Por fim, temos as representações periféricas e menos estáveis (quadrante inferior direito), que contestam as visões do núcleo central.

Debruçando-nos inicialmente sobre o primeiro quadrante de cada tabela/país, que diz respeito ao núcleo central das representações sociais dos estudantes, observamos algumas semelhanças e, também, algumas 
singularidades. Argentina, Chile e Uruguai mostram similitudes na composição do núcleo central, na medida em que os estudantes indicam o nome de personagens habituais da narrativa histórica escolar, considerados protagonistas das epopeias nacionais, em especial no que tange às guerras de conquista ou aos pais fundadores da pátria, que figuram como heróis do panteão político oficial.

Assim, no caso da Argentina, temos menção a San Martín, reconhecido como o libertador das Américas, "figura sobre-humana e fator de reconciliação das parcialidades na segunda metade do século XIX" (AGUIRRE; RUIZ, 2017, p. 3); e a Belgrano, militar que liderou as tropas argentinas na guerra pela independência e compôs o primeiro governo da jovem nação.

No caso chileno, figuram no núcleo central o nome de três próceres nacionais que constituem o período fundacional desta nação: Bernardo O'Higgins, "consagrado como um general vitorioso que deu a independência à pátria” (GONZÁLEZ CALDERÓN; CERRI; ROSSO, 2016, p. 14); Arturo Prat, protagonista da guerra do Pacífico e alçado ao papel de figura paterna em busca da identidade em época de crise; e José Miguel Carrera, apresentado na narrativa histórica oficial como um autêntico caudilho da revolução criolla, herói elegante e simpático.

No núcleo central das representações sociais dos estudantes uruguaios temos a presença hegemônica de Artigas, considerado o pai da pátria e representante máximo das efemérides, cuja data de nascimento (19 de junho) remete a um feriado nacional.

No caso brasileiro, temos que o nome mais prontamente lembrado foi o do descobridor Pedro Álvares Cabral (OME 1,528), embora na frequência das evocações figure apenas em quarto lugar. Pode-se interpretar a presença de Cabral como um ícone, não de si mesmo, considerando o pouco que se estuda de sua biografia, mas da ação dos portugueses na conquista do território; conteúdo escolar tornado canônico, mas sem função exemplar, ou seja, não se trata de um sujeito cuja vida inspira as novas gerações. Destaca-se também, em frequência de evocação, o nome de Tiradentes, símbolo construído pelo movimento republicano brasileiro como mártir da independência, em oposição ao marco monarquista representado por 
D. Pedro I, que aparece com relevância bastante menor, embora dentro do núcleo central. Note-se, ainda, a presença destacada de nomes como Getúlio Vargas e Juscelino Kubitschek, e nomes agrupados na categoria religiosos ${ }^{3}$, em sua maioria personagens do século XX. Isto evidencia o peso da história recente na definição do núcleo central da representação social de heróis por parte dos jovens brasileiros.

Este dado pode ser lido como indício de um novo pressuposto da história escolar, a superação da ideia de que a História consiste no estudo do passado remoto, sem interlocuções com o tempo mais recente. Comparando com os resultados anteriormente apresentados nos estudos da Argentina, Chile e Uruguai, pode-se lançar a hipótese de que se trata de um traço específico da cultura histórica brasileira, um país que se caracteriza por dimensões continentais e práticas culturais bastante diversas nas várias regiões, cujo processo de independência foi bastante peculiar em relação aos outros três países. Por outro lado, há relevantes semelhanças na composição do núcleo central das representações entre os quatro estudos, na medida em que todos evidenciam nomes de personagens masculinos, vinculados à história política e militar, com ênfase à história nacional em detrimento das regionalidades.

É preciso reconhecer, portanto, que o patamar de herói nacional concedido a esses personagens não está relacionado apenas (e sobretudo) à narrativa escolar. Em torno deles mobilizou-se um grande esforço para constituir uma consciência histórica de matriz/constituição de sentido tradicional e exemplar, reforçada no cotidiano das pessoas, pelas efemérides, nos nomes de ruas, escolas, museus, na moeda nacional e até em marcas de erva-mate, como anunciam Alvez Cavanna e Quirici (2017). A consciência histórica, em seu sentido tradicional, segundo Cerri (2011, p. 100-101), direciona atenção para a memória das origens, sendo a identidade erigida pela capacidade de "imitar ou emular as definições culturais preexistentes das formas de convivência”. Já a consciência histórica, em seu sentido exemplar, busca determinadas experiências do passado para

\footnotetext{
${ }^{3}$ A categoria religiosos reuniu 165 evocações, de alguma maneira relacionadas à fé, capitaneada pelo médium Chico Xavier, com 60 evocações; seguindo as menções a Deus, com 49 evocações; e a Jesus Cristo, com 29 evocações.
} 
"reforçar as regras gerais de conduta predominantes em uma dada sociedade", possibilitando a articulação entre o passado, o presente e o futuro, pela validação contínua dessas regras.

Reportando-nos ao quadrante superior direito, que representa a primeira zona intermediária ao núcleo central, novamente identificamos similitudes nos dados da Argentina, Chile e Uruguai e algumas particularidades no caso brasileiro. Note-se que, entre estudantes uruguaios e argentinos, a marcação em branco figurou, respectivamente, como a primeira e a segunda evocação mais frequente. Nessa primeira zona intermediária, jovens argentinos, chilenos e uruguaios continuam a evocar nomes de próceres da nação, como o intelectual e político Domingo Sarmiento, na Argentina; Manuel Rodriguez, símbolo da luta independentista no Chile; no Uruguai, José Pedro Varela, fundador da escola pública, e Lavalleja, político e militar do século XIX, envolvido nas lutas pela independência daquele país.

No caso brasileiro, os dados mostrados na primeira zona intermediária mantêm a mesma particularidade evidenciada no núcleo central, uma vez que ali constam nomes predominantemente contemporâneos (dos séculos XX e XXI), à exceção da presença da Princesa Isabel, personagem do século XIX, construída como a libertadora dos escravos. Neste quadrante figura o nome de Lula que, com 610 evocações, só não consta no núcleo central das representações sociais devido à ordem média de evocação (1,957); e o nome de Dilma Rousseff, então presidente do Brasil. As demais evocações deste quadrante foram consubstanciadas em quatro categorias: nomes do esporte, com 389 evocações, que agrega destacados jogadores de futebol, notadamente o ídolo Pelé (190 evocações) e o piloto Airton Senna (81 evocações); ressignificação, com o total de 303 evocações, que traz em destaque menções a familiares (pai, mãe, avós, tios, irmãos etc.), e a personagens coletivos (professores, indígenas, trabalhadores) como heróis da história do país, denotando a recusa de parte dos estudantes em cultuar as chamadas memórias de bronze; irreverência, com 216 evocações, contém nomes de heróis da ficção em quadrinhos, personagens da mídia e outras manifestações que mostram modos criativos e originais de representar os 
heróis nacionais; por fim, a categoria nomes da música, constituída por 145 evocações, representada por músicos como Renato Russo, Cazuza, Luiz Gonzaga e Raul Seixas, dentre outros.

O quadrante inferior esquerdo de cada tabela representa a segunda zona intermediária ao núcleo central, compondo o sistema periférico das representações sociais. Trata-se, segundo Abric (2001, p. 78), de uma "interface entre a realidade concreta e o sistema central", que mostra a mobilidade e o dinamismo das representações sociais. Aqui já se observa maior diversidade de personagens na indicação dos estudantes e, também, mais aproximação entre os quatro países. Note-se que, com exceção da Argentina, em que os jovens apontaram Cristóvão Colombo e ninguém com maior frequência e menor OME; nos dados do Brasil, Chile e Uruguai aparecem tanto nomes de próceres da nação (D. Pedro II, Caxias, Pedro de Valdívia, Colombo) como nomes contemporâneos, que representam ícones do esporte (Forlan), políticos marcantes (Allende, Wilson Ferreira), líderes sociais (Chico Mendes, Zilda Arns), etc.

Contudo, é no quadrante inferior direito; isto é, na periferia do sistema de representações sociais, que se encontra a maior movimentação e diversidade de personagens tidos pelos jovens como heróis nacionais, evidenciando que a periferia é efetivamente o lugar dos paradoxos e contradições, funcionando como uma espécie de para-choque em relação ao núcleo central. Note-se que toda a sorte de personagens compõe o sistema periférico, podendo-se constatar extrema semelhança entre os quatro países, neste quadrante. Destaca-se a coexistência de nomes de próceres do panteão nacional, com personagens da cultura, da música, do futebol, da política. São personagens identificados temporalmente em uma larga duração, que se estende do século XVI ao século XXI, denotando uma ideia de linearidade temporal e continuidade. Esses extremos podem ser ilustrados com os nomes de Cristóvão Colombo, passando por Mitre, Violeta Parra, até chegar a personagens como Mujica e Maria da Penha, por exemplo. 


\section{CONSIDERAÇÕES FINAIS}

Em um esforço de síntese reflexiva, buscamos recuperar algumas linhas de força que permitem uma aproximação à questão central deste estudo, cujo propósito é compreender as interpretações que os estudantes fazem do passado, notadamente no que se refere às suas representações sociais sobre heróis nacionais, considerando as implicações entre a consciência e a cultura histórica, a construção da nacionalidade/identidade nacional e o ensino da História na escola.

Um primeiro aspecto a ser destacado, tomando os dados em seu conjunto, é a similitude manifestada no núcleo central e nas duas primeiras zonas intermediárias das representações sociais dos estudantes argentinos, chilenos e uruguaios, e a singularidade/diferenciação da experiência brasileira. O centro de gravidade da representação social dos estudantes dos três países está localizada na temporalidade mais remota, predominantemente entre os séculos XVI e XIX, e circunscrita aos heróis do panteão político oficial, às chamadas memórias de bronze. A presença tão marcante de tais personagens nas representações sociais destes estudantes indica a formação de uma consciência histórica com funções tradicional e exemplar. A função tradicional, de acordo com Rüsen (2001), enfatiza a origem e a permanência de determinado modelo cultural comum, cuja moralidade se apresenta como um conceito preestabelecido e inquestionável, em que o tempo é eternizado como sentido. Já a função exemplar constitui-se na interação entre as regras gerais e a experiência histórica, em que o tempo é expressado como sentido.

Os heróis nacionais que habitam as representações sociais dos jovens argentinos, chilenos e uruguaios cumprem função tradicional, no sentido de se remeter à memória das origens e função exemplar, na medida em que se busca as experiências do passado para reforçar determinadas condutas a serem adotadas na vida prática: no caso dos próceres, são modelos de coragem, abnegação, amor à pátria e à coletividade, dentre outras virtudes. Os dados fornecidos pela pesquisa realizada com os jovens brasileiros direciona-nos à hipótese de que, em sua consciência histórica, coexistem as funções tradicional e exemplar, agregando a elas indícios das funções crítica 
e genética, uma vez que percebemos, na totalidade dos quadrantes, desde o núcleo central até a periferia, a presença de diversos sujeitos históricos que representam forças de resistência e de negação de ideias e práticas sociais hegemônicas. Estas características que se apresentam em todos os quadrantes, no caso das representações sociais dos jovens brasileiros, é encontrada apenas na última periferia (quadrante inferior direito) entre os jovens que compõem o estudo na Argentina, Chile e Uruguai. Disso depreende-se que o núcleo central das representações sociais, no caso brasileiro, contém menor hierarquia e estabilidade em relação aos outros países integrantes da pesquisa. Ainda, evidencia que uma característica tão extensa e plural da periferia permite-nos visualizar a representação social como um sistema vivo, dinâmico, em constante movimento.

Sem o aprofundamento dos estudos é difícil afirmar as razões dessa particularidade brasileira, mas se pode levantar algumas hipóteses: 1) as dimensões geográficas e a diversidade cultural do Brasil desfavorecem a construção de uma identidade nacional mais homogênea; 2) há menor efetividade dos agentes/instituições públicos brasileiros (Igreja, Escola, Exército, Imprensa, Estado) na preservação dos rituais e monumentos cívicos que impactem a cultura histórica das novas gerações; 3) visualiza-se um movimento de certa resistência/irreverência dos professores e estudantes frente a uma tradição escolar e a um modelo de ensino de História que prioriza o estudo dos chamados grandes homens, das efemérides e das temporalidades remotas.

Uma segunda linha de força, evidenciada nos estudos que analisamos, refere-se à presença de categorias como ressignificação, irreverência e câmbio de significado, as quais expressam atitudes de recusa dos estudantes frente ao sistema tradicional de representação dos personagens que figuram na história nacional e na cultura histórica. Em tais categorias está consubstanciada a presença de anti-heróis, de celebridades e subcelebridades da mídia, de personagens da ficção, figuras de resistência e contra-hegemonia, dentre outros. Ganha destaque, também, a ocorrência de categorias como en blanco, nadie, ninguno, ninguém, revelando que, ao menos no sistema periférico de suas representações sociais, parte dos jovens estão a negar 
que existam heróis, aproximando-se da visão de Gumbrecht (2011), que alerta sobre a perda da convicção de que a História tenha algo a nos ensinar para a condução da vida cotidiana, ainda que se visualize maior interesse pelo passado, notadamente em museus, programas de televisão, livros, filmes, patrimônio histórico etc. Este autor explica a falta de legitimação pedagógica da História argumentando que, "desde muitas décadas, ninguém realmente leva a sério personagens da história como modelo de atuação" (GUMBRECHT, 2011, p. 28).

Outro ponto a ser destacado, em uma análise que considere o conjunto dos países que compõem a pesquisa, concerne à presença hegemônica das figuras masculinas indicativas dos heróis nacionais nas representações sociais dos estudantes. Note-se que no núcleo central das representações figuram apenas homens, predominantemente políticos, militares e conquistadores. Nos quadrantes superior direito e inferior esquerdo estão ausentes as figuras femininas no caso da Argentina, Chile e Uruguai. As mulheres comparecem nos três quadrantes periféricos da amostra brasileira, sendo representadas por apenas quatro nomes: Princesa Isabel, Dilma Rousseff, Zilda Arns e Maria da Penha. Na amostra uruguaia não figuram nomes femininos e, no caso de Argentina e Chile constam, respectivamente, os nomes de Eva Perón e de Violeta Parra. Na mesma direção, estão ausentes das representações sociais dos jovens que integram os estudos nos quatro países, os sujeitos históricos ligados aos povos afrodescendentes e às populações indígenas. A única exceção identificada nessa dimensão étnica é a presença de Zumbi, um dos líderes do Quilombo dos Palmares, que figura no quadrante inferior direito na amostra brasileira. Entendemos que este dado denota o embate entre uma cultura histórica que favorece as representações de gênero masculinas, brancas e europeias como referências reconhecidas de exemplaridade histórica, de conduta e cidadania; e as novidades do conhecimento histórico disciplinar, que já discutiu, incluiu e apropriou-se destes personagens na composição da compreensão e do conhecimento histórico acerca do passado.

A visualização da galeria de heróis eleita pelos estudantes argentinos, brasileiros, chilenos e uruguaios motiva a seguir perguntando sobre 
o papel da escolarização das histórias nacionais para a formação de identidades sociais e históricas, e do ensino de História, quando se coloca à serviço, como instrumento, da manutenção da cultura histórica vigente e do funcionamento das representações sociais. Embora tenhamos lidado com representações que não tiveram necessariamente proveniência, em sua construção, do ambiente escolar, já que as expressões de cultura histórica abrigam diversas fontes de informação, é forçoso admitirmos e importante percebermos o potencial construtivo (e ao mesmo tempo controlador) da história escolar. Isto porque ela é capaz de fornecer alimento à memória dos estudantes, e operar com recortes, lembranças e esquecimentos, próprios de seu domínio.

Neste sentido, a tarefa de aproximação das interpretações dos estudantes sobre o passado histórico é produtiva, porque permite, também, questionarmos sobre que história e a história de quem é ensinada na escola, e assumirmos responsabilidades frente a um conhecimento disciplinar e escolar que possui uma maleabilidade perigosa, no que diz respeito à produção de violências culturais e amarras morais, identitárias e de poder.

\section{REFERÊNCIAS}

ABRIC, J. C. Central system, peripheral system: their functions and roles in the dynamics of social representations. Papers on Social Representations/ Textes sur les représentations sociales. Áustria/Reino Unido, v. 2, n. 2, p. 75-78, 1993.

ABRIC, J. C. A abordagem estrutural das representações sociais. In: MOREIRA, A. S. P; OLIVEIRA, D. C. de. Estudos interdisciplinares de representação social. Goiânia: AB Editora, 1998, p. 27-38.

ABRIC, J. C. Práticas sociales y representaciones. México: Ediciones Coyoacán, 2001.

AGUIRRE, M. C.; RUIZ, M.C. Entre el desconocimiento juvenil y las nuevas demandas de ejemplaridad. Las representaciones sobre los héroes en la Argentina actual, 2017 (mimeo). 
ALVES-MAZZOTTI, A. J. Representações sociais: aspectos teóricos e aplicações à educação. Em Aberto, Brasília, v. 14, n. 61, jan./mar. 1994, p. 60-78.

ALVEZ CAVANNA, F.; QUIRICI, G. Héroes del Uruguay, 2017 (mimeo).

CARRETERO, M. Documentos de identidade: a construção da memória histórica em um mundo globalizado. Porto Alegre: Artmed, 2010.

CARVALHO, J.M.de. A formação das almas: o imaginário da República no Brasil. São Paulo: Companhia das Letras, 1998.

CERRI, L. F.; CAIMI, F. E.; MISTURA, L. A força da cultura histórica: representações de estudantes brasileiros sobre heróis nacionais, 2017 (mimeo).

CERRI, L.F. Ensino da história e consciência histórica. Implicações didáticas de uma discussão contemporânea. Rio de Janeiro: Editora FGV, 2011.

DE CERTEAU, M. A operação histórica. In: LE GOFF, J.; NORA, P. (Dir.). História: novos problemas. 2. ed. Rio de Janeiro: Francisco Alves, 1988.

GUMBRECHT, H.U. Depois de "depois de aprender com a história”, o que fazer com o passado agora? In: NICOLAZZI, F.; MOLLO, H.M.; ARAUJO, V.L. Aprender com a história? O passado e o futuro de uma questão. Rio de Janeiro: Editora FGV, 2011, p. 25-42.

GONZALEZ CALDERÓN, F.; ROSSO, A.; CERRI, L.F. Heróis e cultura histórica entre estudantes no Chile. Revista Brasileira de História. São Paulo, v. 36, nº 71, p. 179-201, 2016.

GRUZINSKI, S. O historiador, o macaco e a centaura: a "história cultural" no novo milênio. Revista Estudos Avançados, São Paulo, v. 17, n. 49, p. 321342, set./dez. 2003.

KUSNICK, M.R.; CERRI, L.F. Ideias de estudantes sobre a história: um estudo de caso a partir das representações sociais. Cultura Histórica \& Patrimônio, Alfenas, v.2, n.2, p. 30-54, 2014.

MICELI, P. O mito do herói nacional. São Paulo: Contexto, 1997. 
MOSCOVICI, S. A representação social da psicanálise. Tradução de Álvaro Cabral. Rio de Janeiro: Zahar, 1978.

PRADO, M.L.C. Repensando a história comparada da América Latina. Revista de História, São Paulo, n. 153, p. 11-33, dez. 2005.

ROMERO, L.A. (Coord.). La Argentina en la escuela. La idea de nación en los textos escolares. Buenos Aires: Siglo XXI Editores, 2004.

RÜSEN, J. ¿Qué es la cultura histórica ?: Reflexiones sobre una nueva manera de abordar la historia. In K. Füssmann, H. T. Grütter, \& J. Rüsen (Eds.), Historische Faszination. Geschichtskultur heute. Weimar, Böhlau, 1994, p. 3-26 (versão traduzida para o espanhol por F. Sánchez Costa e Ib Schumacher).

RÜSEN, J. Como dar sentido ao passado: questões relevantes de metahistória. Revista História da Historiografia, Ouro Preto, n. 2, p. 163-209, mar. 2009.

RÜSEN, J. História Viva. Teoria da história III: formas e funções do conhecimento histórico. Brasília: Editora da UnB, 2007.

RÜSEN, J. Razão Histórica. Teoria da História: os fundamentos da ciência histórica. Brasília: Editora da UnB, 2001.

THIESSE, A.M. Ficções criadoras: as identidades nacionais. Anos 90, Porto Alegre, n. 15, 2001/2002.

VERÍSSIMO, J. A educação nacional. 3. ed. Porto Alegre: Mercado Aberto, 1985.

VIDAL, D.G.; ASCOLANI, A. (Orgs.). Reformas educativas no Brasil e na Argentina: ensaios de história comparada da educação (1820-2000). São Paulo: Cortez, 2009. 


\section{HERÓIS VELHOS EM URUGUAIOS JOVENS}

Federico Alvez Cavanna

Gabriel Quirici

O presente artigo analisa o segmento das respostas da pesquisa Jovens e a História no Mercosul, na sua amostra do Uruguai, em escolas do âmbito público e também do particular, da capital e do interior, com o objetivo de sondar diversos aspectos do ensino e da aprendizagem da disciplina.

Neste caso, entre os muitos dados que a enquete oferece, o foco foi colocado nas opções relacionadas com os heróis históricos nacionais indicados pelos jovens uruguaios. Na primeira parte do texto, descrevem-se os dados obtidos e formulam-se alguns critérios para sua análise e síntese. $\mathrm{Na}$ segunda seção, são propostas algumas reflexões disciplinares e didáticas, em que os dados sugerem como convite para pensar as relações entre a História ensinada e os imaginários coletivos.

\section{ARTIGAS, A POLÍTICA E O FUTEBOL}

O questionário realizado em 228 (duzentos e vinte e oito) casos oferecia a oportunidade de preencher três linhas vazias com o nome de três heróis nacionais, por ordem de importância para o estudante. No total, representam 684 (seiscentos e oitenta e quatro) respostas possíveis, com diferentes níveis de importância, de 1 a 3, em ordem hierárquica decrescente.

A enquete foi realizada com estudantes de 15 anos, no ano de 2012, permitindo rastrear diferentes percepções de como é assimilada, pelos adolescentes, a palavra herói, em um contexto de escolarização determinado pelo ensino da História. É importante lembrar a influência do contexto geral de apresentação da enquete para os jovens: ela foi aplicada com docentes de História em suas aulas no âmbito escolar e explicando que, entre os seus objetivos, estava a pesquisa sobre a História ensinada.

A multiplicidade de respostas foi interessante. No entanto, é possível extrair alguns comportamentos gerais suscetíveis de serem analisados 
para refletir sobre a mitologia histórica escolarizada e sua relação com a cultura histórica uruguaia.

Desde já, adiantamos que mergulhar nos resultados da enquete significa encontrar uma estimulante variedade: como casos (isolados e irreverentes) em que as três respostas coincidem com super-heróis de história em quadrinhos (Batman, Superman e Flash), outros colocaram seus pais, e as mais repetidas são as que apresentam uma visão quase de história oficial, em que os heróis escolhidos foram o panteão político-nacional (Artigas, Lavalleja e Rivera). No meio desses extremos, observam-se alguns mixes entre figuras políticas da História (com absoluto predomínio de Artigas), futebolistas destacados em nível internacional, políticos do presente e, também, figuras da cultura (Mario Benedetti, Jorge Drexler).

Para sintetizar os dados, foram consideradas as decisões metodológicas que seguem.

1. Em primeiro lugar, analisam-se os casos de respostas negativas ou vazias;

2. Em seguida, descrevem-se os resultados dos heróis mencionados no total da amostra, para elaborar um ranking de Heróis escolarizados;

3. Por fim, analisam-se as respostas por estudante, com a finalidade de encontrar padrões de resposta individuais.

Para a construção do ranking de heróis escolarizados foram consideradas todas as respostas, com exceção das vazias. No total, foram 228 (duzentos e vinte e oito) estudantes que tinham 684 (seiscentos e oitenta e quatro) células para completar. Uma vez terminada a enquete, as células efetivamente completadas (com heróis escritos) foram 506 (quinhentos e seis), e com estas últimas construímos o ranking no total. No entanto, para a identificação de possíveis padrões de resposta, elas foram analisadas individualmente. Sendo assim, os 100\%, neste corte, corresponde aos 228 (duzentos e vinte e oito) alunos que responderam. 


\section{SEM HERÓIS}

Pouco menos de $25 \%$ das células foi completado com a palavra nenhum herói, ou deixadas em branco. Com a particularidade que aqueles que escreveram explicitamente nenhum [sic], fizeram isso nas três células, deixando claro sua posição em não destacar nenhum herói.

Por outra parte, observa-se que as células em branco vão crescendo na medida em que o nível de importância hierárquica vai diminuindo. Muitos estudantes (18\%) preencheram somente a primeira caixinha/lacuna, e deixaram vazios os dois restantes.

Sendo assim, poderíamos afirmar, com segurança, que desses $25 \%$ de ausência de heróis na tabela, somente $5 \%$ não as completa ou manifesta não ter heróis explicitamente. Enquanto o restante $20 \%$ somente assinalou um herói, o que poderia ser interpretado como falta de significado substantivo para o estudante, de parte da temática proposta.

Resumindo, um quarto das respostas da amostra dá a impressão de que o tema não lhes foi relevante e, dentro deste um quarto, um pequeno núcleo duro, de $5 \%$, não respondeu ou somente afirmou sua resposta utilizando a palavra nenhum.

\section{RESULTADOS INICIAIS: HERÓI POR HERÓI}

Abordamos, agora, a descrição dos resultados daqueles que escreveram seus heróis e apresentamos os resultados em nível individual e, posteriormente, certos padrões de respostas combinadas, que permitem analisar com mais detalhes a enquete.

Entre os que escreveram minimamente um herói, o ranking de celebridades mencionadas foi o seguinte: José Artigas: 30\%; José Pedro Varela: 11\%; Lavalleja: 8\%; Rivera: 5\%; Aparicio Saravia 3,5\%; Oribe, Batlle y Luis Suárez: 3\%; Forlán y Tabaré Vázquez: 2\%; Mujica: 1,5\%, Benedetti: 1\%; e "Tupamaros" [sic], Sanguinetti y Seregni: 0,5\%. Estas listas compreendem os nomes que se repetiram no mínimo duas vezes, em um total de 508 casos e contando, também, com $28 \%$ de outros que aparecem só uma vez, em que se encontram Rada, Benedetti, meus pais, operários, Lolo Estoyanoff, 
Batman, entre outros, além de uma grande diversidade de casos entre o criativo, o original e o curioso.

Na continuação, mostra-se uma análise detalhada das opções que foram apresentadas pelos estudantes, com base nos critérios expostos anteriormente. Em primeiro lugar, pode-se observar que o ranking individual destaca a importante maioria relativa de menções para Artigas, com relação aos restantes, já que triplica a quem lhe segue na sequência, José Pedro Varela.

Entre os estudantes que colocaram algum herói, José Artigas obteve $30 \%$ das menções, com a particularidade de que, se somente for considerada a primeira coluna, ou seja, o primeiro herói em importância, Artigas têm $63 \%$ das escolhas.

Figura 1 - Menções de heróis nacionais uruguaios* (em porcentagem)

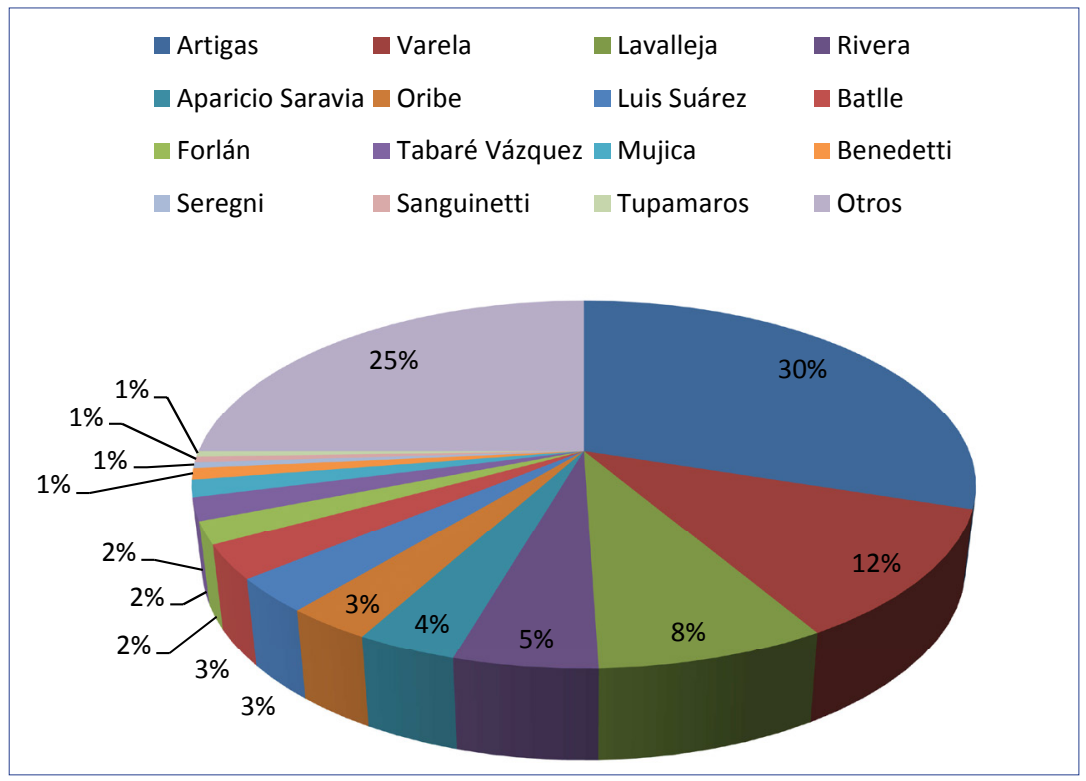

Fonte: dados do projeto Jovens e a História (2013). Elaboração dos autores.

* Entre os estudantes que preencheram pelo menos um dos nomes solicitados

O segundo mais nomeado foi José Pedro Varela, com 11\%; depois, Lavalleja com $8 \%$ do total. Como se analisa posteriormente, a figura de 
Artigas possui um caráter quase de onipresença simbólica nos uruguaios, e seu caso merece uma análise específica, que transcende uma mera nota de concordância, entre uma história oficial ensinada e um resultado destacado de seu lugar na enquete.

Em relação aos outros heróis que lhe seguem na ordem de indicações, podemos realizar algumas considerações. José Pedro Varela $\left(\mathrm{n}^{\circ} 2\right)$ foi o autor da reforma escolar de 1877, promovendo o ensino gratuito e obrigatório que, após a sua prematura morte enquanto exercia o cargo de Director Nacional de Educación Pública, passou a integrar o panteão nacional de forma permanente.

Sua imagem está em todas as escolas públicas, os cadernos e boletins de notas escolares levam seu retrato na capa e, no Uruguai, falar de educação vareliana constitui um valor-saber conhecido e predominante, que se associa aos pilares da educação republicana, gratuita, universal e laica.

Portanto, os dois primeiros heróis do ranking estão relacionados a figuras de dimensão nacional, que não tem claramente uma identificação partidária. Artigas teve sua atuação política antes que os partidos tradicionales existissem, e Varela foi ministro durante um governo militar de escasso perfil partidário.

No terceiro e quarto lugar apareceram duas referências históricas dos partidos tradicionales (colorados, com Rivera no $\mathrm{n}^{\mathrm{0}} 4$; e blancos, com Lavalleja em $3^{\circ}$ ) que, ao mesmo tempo, formaram parte dos exércitos revolucionários de Artigas e que, posteriormente, protagonizaram as primeiras presidências e golpes de estado de vida independente, dando origem aos bandos políticos tradicionais. Casualidade ou não, Lavalleja, que foi um líder na luta pela independência contra o Império do Brasil, em 1825, mas que nunca conseguiu chegar a ser Presidente (embora tenha tentado legalmente e também através de levantes armados), sempre aparece nas colunas 2 ou 3 , mas nunca em primeiro lugar. Parece ser um integrante do panteão que sempre acompanha, mas que não é visto como líder.

Em um terceiro nível do panteão, aparecem Oribe (fundador do partido blanco) e duas figuras da última guerra civil (1903-1904) e dos inícios 
do Uruguai moderno, do século XX: José Batlle e Ordoñez, do partido Colorado; e Aparicio Saravia, do blanco.

Agrupando os heróis, observa-se um predomínio das figuras tradicionais, indicadores do padrão clássico. Juntando as citações a personagens correspondentes ao panteão histórico (Artigas, Varela, Lavalleja, Rivera, Oribe, Batlle e Saravia), chegam a 63\% do total. Enquanto a segunda categoria que lhe segue em nomeações é a dos jogadores de futebol (com Luis Suárez liderando, mesmo ainda não jogando no Barcelona), que chega a $11 \%$ do total. Os políticos com atuação no presente alcançam 7\%, e representantes da cultura obtém $5 \%$ das indicações.

Observando a lista completa, os nomes, suas repetições e hierarquias, podemos confirmar um viés tradicional/ nacional e político na hora de mencionar heróis, desde o olhar de uma enquete sobre ensino da História realizado em diversos colégios.

\section{PADRÕES DE RESPOSTAS OBSERVADOS: CLÁSSICOS, FUTEBOLÍSTICOS E POLÍTICOS}

Sobre os padrões de reposta combinada, atrevemo-nos a distinguir alguns casos que, por reiterados, dão ideia de uma forma de conceber a heroicidade por parte de diferentes grupos dos consultados.

1. Em primeiro lugar, temos as respostas clássicas, aquelas que, em todos os casos, mencionam figuras políticas históricas vinculadas ao panteão histórico nacional e partidário. Neste caso, a combinação Artigas-Varela resulta ser a mais habitual, e recolhe entre os legados da construção simbólica nacional: ao prócer (Artigas) e ao fundador da escola pública (José Pedro Varela). Também aparecem mencionados os líderes originários dos partidos tradicionais (Rivera, Oribe, Lavalleja), ou figuras relevantes da guerra civil de 1904 (Aparicio Saravia, blanco; e Batlle, colorado). Quando todas as respostas têm algum dos mencionados, podemos afirmar que estamos ante uma resposta clássica. 
2. Em segundo lugar, temos as respostas culturais/futebolísticas. Casos nos quais o participante da enquete optou por marcar a destacados futebolistas ou atores da cultura (cantantes, pintores, escritores), evitando cair na resposta clássica, sem mencionar líderes políticos do panteão histórico nacional.

3. Em terceiro lugar, encontramos respostas politicamente recentes, em que o herói escolhido corresponde a personalidades da política dos anos 1960 até os dias atuais: Raul Sendic, Liber Seregni, Julio María Sanguinetti, José Mujica, Tabaré Vázquez, Luis Alberto Lacalle e Wilson Ferreira Aldunate. Esses casos nunca aparecem em estado puro, pois sempre estão acompanhados de outro tipo de líderes correspondentes aos padrões anteriores.

Por último, é importante destacar que existe um variado número de respostas combinadas, em que se misturam o clássico com o futebol, Artigas com os políticos atuais ou cantores com heróis do passado. As análises dessas combinações estão na parte seguinte deste texto.

\section{RESPOSTAS POR ALUNO}

Considerando o total de alunos (228) que responderam a enquete, os resultados observados foram os seguintes:

Tabela 1 - Respostas por aluno

\begin{tabular}{l|c|c}
\hline & Casos & $\%$ \\
\hline Artigas & 142 & 62,3 \\
\hline Panteão (sem considerar Artigas) & 124 & 54,4 \\
\hline Futebol & 38 & 16,7 \\
\hline Políticos recentes & 32 & 14 \\
\hline Cultura & 24 & 10,5 \\
\hline
\end{tabular}

Fonte: Dados do Projeto Jovens e a História (2013). Elaboração dos autores. *Entre os estudantes que preencheram pelo menos um dos nomes solicitados.

Como os estudantes podiam responder até três heróis, as combinações muitas vezes se agregam e, por isso, as porcentagens da tabela somam mais de 100 . 
Um olhar geral apresenta que quase dois terços dos estudantes colocaram Artigas como herói e, mais da metade, respondeu com figuras históricas do panteão tradicional. O fator mais reiterado pelos estudantes foi escrever Artigas; depois, outras figuras do panteão e, finalmente, acompanhar com alguns esportistas. Somente aparecem, ocupando o terceiro lugar, os jogadores do futebol, mas um quinto dos estudantes os menciona.

Figura 2 - Menções de heróis nacionais uruguaios* (em porcentagem)

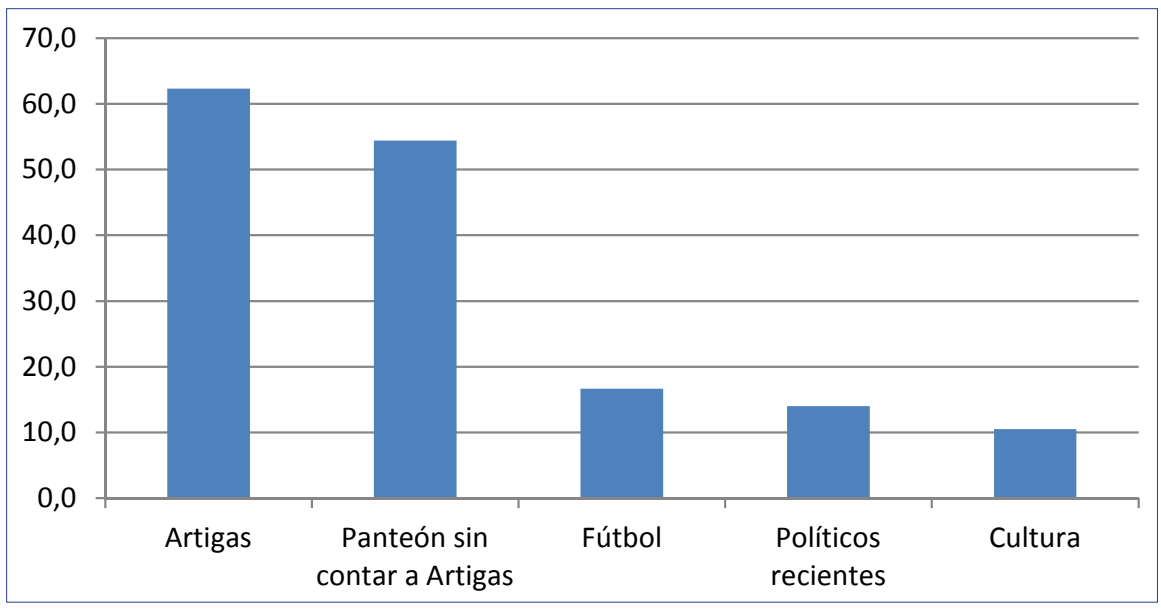

Fonte: Dados do Projeto Jovens e a História (2013). Elaboração dos autores.

*Entre os estudantes que preencheram pelo menos um dos nomes solicitados.

Agrupando os tipos de repostas em todos os casos como Panteão, Futebol, Políticos Recentes ou Cultura, o segundo herói que mais aparece junto é, mais uma vez, a figura de Artigas; ou seja, entre aqueles que escolheram futebolistas, a maioria dos outros mencionados correspondeu para Artigas, e o mesmo aconteceu em outros casos. Sendo assim, percebemos a confirmação de um nítido predomínio de Artigas em primeiro lugar e o histórico-oficial em segundo plano que, somados, diferenciam-se com distância do resto dos heróis.

Percebemos, então, que o terceiro grupo é o de futebolistas, com um viés predominantemente masculino. Ainda, não figuram, entre as preferências, cantores de músicas populares mais recentes, ou estrelas da mídia adolescente. As figuras da cultura mencionadas, no geral, correspondem a 
personalidades do mundo adulto (Mario Benedetti e Idea Vilariño são poetas da chamada Generación de 1945) ou cantores de reconhecimento internacional (como Ruben Rada na Argentina, ou Jorge Drexler na Espanha, e pela obtenção do Oscar de melhor canção no ano de 2005). Com a exceção de duas ocasiões em que são mencionados grupos de rock, todas as vezes, os personagens da cultura podem ser associados com o sentido de completar a enquete de forma séria (e, porque não, um pouco chata?).

Confirma-se, assim, a impressão inicial, de que os estudantes colocam-se em situação de responder uma enquete para a disciplina de História em um âmbito formalizado desde o escolar e que, provavelmente, guardaram seus ídolos juvenis por considerá-los menos formais ou não tão nacionais.

Devemos agregar, ainda, que uma dificuldade a mais para que isto aconteça é que, no Uruguai, a indústria midiática é economicamente muito fraca e, por isso, muitas das estrelas são figuras internacionais da mídia televisiva, o que deixa ainda mais difícil de serem associados com heróis da história nacional.

No entanto, o futebol país constitui uma forte senha de identidade e uma grande escala de visibilidade internacional; então, alguns jogadores de futebol podem ser entendidos como resposta aceitável para heróis. Um esportista de destaque que nos represente (assim fala-se na mídia, como embaixadores do Uruguai) e, ainda mais, que realizem suas atividades de sucessos na própria Seleção Nacional.

Vários autores (PIÑEYRÚA, 2014; MORALES, 2014) têm analisado o componente cultural/indenitário do futebol e sua relação com as desigualdades sociais e a adolescência, tratando-se de uma das primeiras opções laborais ou de carreira que muitas famílias uruguaias consideram como possível e desejável para o futuro de seus filhos. Sendo até provável, neste sentido que, para os jovens de 15 anos que escolheram futebolistas, essa realidade pessoal tenha influenciado. Por outra parte, em um país pequeno, essa atividade esportiva, que consegue presença e visibilidade internacional, constitui-se em um fator de orgulho nacional e de reconhecimento. Além de momentos melhores ou piores, o futebol tem constituído um dos exemplos de mais longa duração, considerando, também, que a enquete foi realizada 
depois da conquista da Copa América 2011, realizada na Argentina, e da quarta colocação na Copa do Mundo da África do Sul, em 2010.

Por isso, este grupo de estudantes da enquete apresenta um sentido de heroísmo desportivo nacionalista recente, com uma única exceção que chama atenção e até apresenta um aspeto simpático: um jovem citou Alcides Edgardo Ghiggia (autor do segundo gol na final de Maracanã na copa de 1950), provocando dúvida, entre os pesquisadores, se deveria ser contabilizado como parte das respostas do futebol ou do Panteão. Considerando estes comentários gerais sobre os outros tipos de respostas, minoritários, devemos lembrar e sublinhar o predomínio do clássico, historicamente esperável. Na segunda parte, aportamos reflexões para compreender um resultado tão conservador e reiterado.

\section{OS VÁRIOS HERÓIS POR TRÁS DA FIGURA DE ARTIGAS}

As imagens de Artigas, como herói nacional, transcendem amplamente a História ensinada em nível secundário, e relacionam-se diretamente com uma cultural histórica prévia e que contextualiza sua figura, que é utilizada como referência em diversas instâncias de formação de opinião e construção de imaginários coletivos.

A presença de Artigas, destacada entre os jovens uruguaios consultados, tem pouca relação com a História que se ensina dentro das escolas, pois a temática da revolução hispano-americana e oriental está presente somente no segundo ano. Não ocupa um lugar central nos currículos, já que aparece entre as últimas unidades do programa oficial e, também, é muito provável que, em muitos casos, os alunos tenham vivenciado poucas aulas sobre o período revolucionário.

Desta forma, encontramo-nos com um tipo de resposta majoritariamente relacionada com uma atitude do dever ser, muito mais do que com um resultado de aprendizagens historiográficas próprias das aulas. Isto Permite apresentar algumas características em relação à construção de Artigas, muito além das salas de aula, na qual participam desde atores políticos, com visões ideológicas distintas, até a publicidade de marcas de erva mate que utilizam sua imagem. 
Discursos em que desaparecem as aporias e os debates de o político, apresentam-se e constituem-se como um discurso neutro. Por isto, é importante se questionar: Quem é o Artigas que os jovens escolheram? Aquele do discurso romântico nacionalista? O neutro do pensamento Ilustrado? O conveniente da boa resposta escolar, dentro da lógica memorialística de uma visão de mundo unificada e exemplar? O Artigas uruguaio ou o herói regional? Quantas diferenças se escondem por trás da aparente homogeneidade de Artigas?

Estas reflexões permitem lembrar a importância de considerar que a disciplina História não gera somente problemas para o campo educativo ou cognitivo, mas dentro construção formativa de identidades nas novas gerações, tanto no campo político, social e, também, cultural para agir no mundo.

\section{OS DISCURSOS ANTERIORES À FRENTE AMPLIO}

Um bom exemplo para ver esta criação do múltiplo Artigas à la carte são os discursos pronunciados em homenagens, nos atos oficiais, a cada 19 de junho (dia do natalício do prócer), quando governava o Partido Colorado em aliança com parte do Partido Nacional (Blanco). Pode-se observar uma geração de sentido da história que se identifica com o tradicional, partindo de narrativas oficiais. Por exemplo, Alfonso Varela, no ano 2000, sendo Ministro de Turismo no governo de Jorge Batlle Ibañez, foi o orador principal em representação do Poder Executivo. Em sua oratória, afirmou que "Cada generación tiene su Artigas. Como si éste hubiera construido un medio puente hacia cada uno de nosotros y nos hubiera déjalo la posibilidad de construir la otra mitad". Essa primeira parte da ponte marca uma continuidade, em que a segunda deve ser encaixada de forma imutável e linear.

Querendo falar sobre a Guerra Fria e os conflitos políticos nos anos 60 no Uruguai, começa afirmando que a primeira metade da ponte foi quando Artigas combateu dois impérios (Espanha e Portugal) que, "tras San Ildefonso y Tordesillas se habian repartido el mundo... Nuestra tierra oriental fue uno de los límites de esos dos imperios", para depois finalizar a engenharia da obra edilícia: 
La realidad mundial en 1960 y 1970 era similar a la época de Artigas. Dos grandes naciones dominaban el mundo... Nuestro país no fue ajeno a esa lucha. Nos olvidamos del ideario artiguista. Nos enfrentamos oriental contra oriental. Se defendieron modelos e ideas que no eran los nuestros. (VARELA, 2000) ${ }^{1}$

Devemos ter presente que, no dia 21 de março do ano 2000, foi reconhecida a verdadeira identidade de Macarena Gelman (neta do poeta Juan Gelman e filha de detidos-desaparecidos), quebrando a ideia sustentada durante muitos governos do pós-ditadura, que negavam a existência de casos de crianças sequestradas e desaparecidas no Uruguai. O sentido principal do discurso resulta da pretensão de orientar o presente, a partir de uma determinada visão do passado, que outorga mais informação sobre o orador e sobre a imagem que determinado grupo quer ter de si, mesmo que sobre o próprio Artigas. O modo exemplar da consciência histórica, como afirma Cerri (2011, p. 101), é resultado de apresentar ao passado:

[...] como um conjunto de exemplos, cuja função é reforçar as regras gerais de conduta predominantes em determinada sociedade. A articulação entre passado, presente e futuro acontece em função da contínua validade dessas regras. No passado são encontrados os modelos a seguir de modo a dominar o presente e estabelecer o futuro.

Será, novamente, essa pretendida continuidade essencialista que levou ao Ministro Industria, Mineria e Energia Pedro Bordaberry, como orador principal no ato do ano 2002, a afirmar que:

El lugar es el mismo, pero la realidad no. Lo que no quiere decir que no haya situaciones similares puesto que la región y el País siguen siendo parecidos... todos seguimos buscando las mismas cosas que buscaba Don José. Y enfrentando problemas parecidos (BORDABERRY, 2002).

Em relação aos problemas que o país enfrentava no início do século XIX, insiste a ideia de essência imutável: "Curiosos designios los del destino que nos coloca en similares situaciones y nos hace reaccionar de manera parecida. Es que la realidad es distinta pero la situación geopolítica es similar" (BORDABERRY, 2002). Esta perene situação permite, como já tinha sido feito pelo Ministro Varela, afirmar que

\footnotetext{
${ }^{1}$ Os discursos dos atos comemorativos do 19 de junho foram extraídos da página oficial da presidência da República Oriental del Uruguay no período 2000-2005.
} 
Artigas también vivió la lucha de dos imperios que tomaron esta tierra oriental como escenario para dirimir sus conflictos. Los peleó a los dos... Hace algún tiempo volvimos a ser escenario de confrontación. Otros eligieron este lugar como escenario... los muros y las ideologías cayeron, pero quedaron heridas abiertas, de ambos lados (BORDABERRY, 2002).

A consciência histórica, como uma estrutura do pensamento humano, apresenta-se nestes discursos não somente como uma estrutura exemplar, também com um sentido tradicional onde "as origens são postas como uma obrigação para com o futuro. O conteúdo da tradição, nesse caso, é tomado como um dado natural e certo, sobre o qual não existe ou não cabe reflexão ou questionamento" (CERRI, 2011, p. 101).

Artigas configura-se, para esta visão, como a representação da neutralidade, da objetividade e da laicidade no ensino da história nacional. A política parece desaparecer no nome do prócer; no entanto, o político realiza intensas disputas para ocupar o espaço simbólico do conceito Artigas, procurando apropriar-se de seu prestígio. Nestes discursos comemorativos do 19 de junho, a figura política dilui-se em uma hagiografia absolutamente desinteressada sobre o passado, mas muito interessada na eficiência prática, como "peça de propaganda: de verdadeira arma no combate aos hereges" (DOSSE, 2015, p. 145). Suas virtudes são encarnações humanas do sagrado (neste caso vinculado com a Pátria) que, como descreve François Dosse (2015, p.139), propõem uma lenda para gerar identificação, aderência e imitação. Vale lembrar que a origem do conceito de lenda remete à ideia de aquilo que é para ler em liturgias, em atos oficiais, em comemorações.

A didática da História tem, como um de seus trabalhos principais, analisar as variações da utilização destes heróis e, no caso concreto de Artigas, os diversos sentidos que se vinculam a sua figura, na mistura entre o santo laico e o herói. Na fabricação de heróis, a necessária incompletude (a media ponte do Ministro Varela) ressalta o princípio de transcendência que faz com que "cada época cria seus heróis e lhes atribui, quer sejam de uma época distante, próxima ou atual, seus próprios valores. O herói, cristaliza em si uma simbolização coletiva..." sempre disputado (DOSSE 2015, p. 151).

No ano 2001, o responsável da oratória oficial no ato cívico foi o Ministro de Educação e Cultura, Antonio Mercader, integrante do Partido 
Nacional. Em um contexto extremamente sensível, somente dois meses após ser anunciado que o agronegócio uruguaio sofria com focos de febre aftosa, afetando o centro da economia nacional. Neste clima, o Ministro declarou que

Vivimos en tiempos de dificultades, si es verdad, pero ¿no eran acaso tiempos mucho más difíciles los que vivió Artigas dos siglos atrás cuando ni patria había y cuando la amenaza de la intervención extrajera se cernía sobre el país? (MERCADER, 2001).

Sendo tempos de dificuldade, o exemplo de superação que deve ser observado "cuando sobrevienen, una tras otra, las contrariedades, los problemas, las acechanzas... (es) la continuidad de un proyecto que nació aquí, en estas tierras, hace 237 años" (MERCADER, 2001).

\section{O ARTIGAS QUE DEVE SER}

Com sua entrega suprema aos valores da Pátria, particularmente em momentos de adversidade, Artigas é apresentado como o mártir de um coletivo singular, mas a identificação com a nação requer, também, o reconhecimento e a participação dos que aceitam ou não essa relação. Nos discursos dos políticos em atos oficiais, existe um Artigas que pretende ser o modelo para identificar o autenticamente uruguaio, principalmente através de juízos de tipo moral, em que o herói ainda não foi laicizado.

Porém, o Artigas que os estudantes escolhem é único e sagrado, ou resulta de uma construção que permite aprender a pensar o passado, atribuindo diferentes significados, superando modelos exemplares ou tradicionais? Porque, o que está em jogo não é somente a imagem do herói, mas o debate sobre uma didática da História que se pretende dialógica na construção de identidades que abram a possibilidade de aprender a pensar o passado como encruzilhadas de caminhos. Evitando admitir, sem debates nem argumentos, que a forma que se impõe foi a única possível, abrindo, assim, a oportunidade de pensar, também, diversas formas de futuro.

A história oficial é transmitida com conteúdos racionais e emotivos, como algo instituído que deve ser seguido como já é e, para isto, utiliza as imagens de heróis como 
Un verdadero movimiento de sacralidad donde el martirio, en el sentido cristiano, se transforma en martirio por causa de la Patria. Semejante sacrificio presupone la instauración de toda una pedagogía de solidaridad nacional. Con ese propósito, se retoma el antiguo modelo de la Historia Magistrae, de la vida ejemplar de quien entregó su sangre y que existe como figura simbólica de una deuda indefinida, contraída por la comunidad por la cual se sacrificó voluntariamente. La educación y la transmisión del pasado son entonces concebidas de forma explicitas, por sus representantes, como instrumentos que recuerdan la deuda de las nuevas generaciones con sus ancestrales (DOSSE, 2015, p. 179).

No mesmo discurso no ano de 2001, Antonio Mercader afirmou que

Es bueno tener presente las lecciones de nuestra historia por eso la enseñamos en las escuelas y liceos. Por eso es tan importante insistir en que la historia nacional debe enseñarse en profundidad par que nos sirva de guía y para que nos guie y para que nos diga quiénes somos, de dónde venimos, hacia dónde vamos (MERCADER, 2001).

Insiste, portanto, na visão da história como magister vitae, exemplar e tradicional, resultado de um espaço de experiência supostamente contínuo na retórica e na moral. Essa questão introduz o debate sobre a laicidade ${ }^{2}$ no ensino da História, porque

Algunos han querido ver en esta inquietud un presunto ataque al principio de la laicidad. ¡No es así!... Nadie quiere que se adoctrine en una religión, pero jatención! tampoco queremos que se adoctrine en favor de una determinada corriente política. Politizar la enseñanza, aprovechar la cátedra para hacer proselitismo político, es una actitud altamente condenable que ser señalada y combatir. Esta es una de nuestras preocupaciones centrales... (MERCADER, 2001).

A história escolar que se apresenta como neutra e objetiva, sustentada nos fatos do passado, tem uma particularidade adicional, no caso uruguaio, através dos debates sobre a violação da laicidade. Aqui surge um problema, ou melhor, até um não problema, porque a pretensão de neutralidade e de objetividade são problemáticas no sentido de discutíveis, confrontáveis, e os debates sobre a laicidade carregam o paradoxo de ser semirreligiosos.

No entanto, basta lembrar o extenso debate sobre o ensino da História recente (2005 a 2008), em que o principal argumento dos opositores é que o

\footnotetext{
${ }^{2}$ Para o caso italiano, Gentile (2007, p. 18) analisa que "La laicización de la sociedad consistía en producir una unidad moral de los ciudadanos inculcando en su ánimo, los 'dogmas de la religión civil', el sentido del deber cívico y la obediencia al estado".
} 
tema trabalhado nas aulas consistiu em denunciar a violação da laicidade. Este tipo de conceito conservador de um ensino da história laica obedece a uma definição que, desde a política, nega o viés aporético do político, e determina que o Estado deve ser o lugar do neutro. Trata-se de uma história que tem como função descrever modelos (muita ênfase na moral) e nunca restituir problemas (ROSANVALLON, 2003), escondendo a lógica contraditória de denunciar uma politização nas escolas, desde uma hiperpolitização oficial.

Em relação à análise dos resultados dos heróis nacionais, percebemos maioritária presença deste Panteão Laico, que mantém intacta a aparência de uma constante natural com a figura de Artigas, secundada pelas restantes figuras que "son representados como sus hijos más dilectos" (DI GIORGI, 2014, p. 46).

As historiadoras Isabela Cosse e Vania Markarian realizararam um estudo sobre a consciência histórica uruguaia, publicado em livro no ano de 1994, que gera um nós coletivo e que marca uma identificação com o ser uruguaio na "[...] capacidad de reconocer un determinado pasado como pasado común y la de proyectarse al futuro son, entonces, requisitos básicos para la existencia de una comunidad nacional" (COSSE; MARKARIAN, 1994, p. 42). No estudo ${ }^{3}$ aparece uma consciência histórica nacional, elaborada de consensos, principalmente através de dois sustentos unificadores: José Artigas e os Partidos Tradicionais como forjadores da nação. A figura de Artigas aparecia como o personaje más admirado de la historia nacional, com $63 \%$ das opções e as autoras interrogavam:

¿Qué dice de una colectividad el hecho de que no vacile en rendir admiración unánime a una única figura histórica? Habla de una sociedad de consensos, que integra las diferencias y que amortigua los disensos... el artiguismo es quizás la zona más firme de la conciencia histórica nacional. El lugar común de las diferencias en las coincidencias, donde convergen las diversas interpretaciones de la historia y del destino nacional donde contenidos diferentes adoptan un mismo nombre" (COSSE; MARKARIAN 1994, p. 58-59) ${ }^{4}$.

\footnotetext{
${ }^{3}$ En total plantearon 281 cuestionarios semi-estructurados a la población montevideana entre 18 y 65 años con educación primaria completa.

${ }^{4}$ Destacam como caso oposto uma investigação realizada no Peru, onde nenhum personagem superou $13 \%$ dos votos.
} 
Outra operação historiográfica sobre a construção da identidade nacional está vinculada com os dois denominados Partidos Tradicionales, que "han sido, junto con el sistema educativo, los mediadores en la multiplicidad de lecturas académicas y la sociedad, jugando así un papel determinante en la conformación de la consciencia histórica nacional" (COSSE; MARKARIAN 1994, p. 62). É desde o Estado, e também desde os partidos políticos, que fundamentalmente tem-se gerado a produção de sentidos que determinam o que é historicamente correto, o que é racional, o tolerante, o nacional e, principalmente, o laico. Disto resulta que a incorporação da história recente nas aulas gerou um alarme em relação às ideias de sentido comum na sociedade uruguaia.

Resulta inquietante que a figura de Artigas mantenha a constante de uma porcentagem similar de aprovação (mais de 60\% nas primeiras preferências dos estudantes consultados em nosso estudo), com a diferença de que se trata de novas gerações e em um contexto político diferente, com a esquerda governando pela segunda vez consecutiva. De modo que, muito além de ser uma realidade atribuível a concepções sobre o objetivo e os consensos, a figura de Artigas persiste como imagem simbólica primária, acima das mudanças políticas e geracionais.

Pode se tratar de uma continuidade nas formas de ensino e na concepção básica do que é a história escolar, mas é indispensável confirmar elementos de longa duração na cultura, que permitam entender porque Artigas segue sendo escolhido, quando a história oficial já não está dirigida pelos partidos tradicionais. Provavelmente sua condição de líder nacional sem vínculo com aqueles Partidos e a identificação da maioria da esquerda com o pensamento artiguista seja chave para compreender sua extensão simbólica acima das mudanças políticas.

\section{OUTROS ARTIGAS: ENCONTROS E DESENCONTROS}

O historiador José Rilla, em seu trabalho La actualidad del Pasado (2008), destaca que entre a escola e os Partidos definem-se a identidade nacional. Se a política supõe conflito e discórdia, esta sociedade, como muitas outras, armou os conflitos ao redor dos partidos e encontrou, em 
Artigas, um lugar de concórdia e acordos, trabalhosamente construído como centro de uma religião cívica: "para la historia un genio, para la patria un Dios" diz o hino escolar. Esta centralidade política de Artigas, em todo o século XX, permitiu criar um terreno de afinidade entre os dois principais partidos políticos, que reuniam mais de $90 \%$ do eleitorado. No entanto, como afirma Rilla,

La concordia colorada y blanca en torno al prócer (que no había sido blanco ni colorado) se vio desafiada cuando la izquierda unificada en el Frente Amplio asaltó la ciudadela artiguista en la que ambos bandos habian depuesto sus armas [...] Líber Seregni, líder del Frente Amplio en 1971 diría "...el Frente Amplio es el legítimo heredero de la tradición artiguista y toma sus banderas e ideario (RILLA, 2008, p. 235).

Quando o bipartidarismo tradicional foi questionado e entrou em crise com o surgimento de uma colisão de esquerdas (Frente Amplio), a figura de Artigas não foi questionada, mas resinificada também, desde aquele setor ideológico. Como narra Jaime Yaffé (2001, p. 412, grifos do autor),

A la leyenda "negra" perpetrada por los vencedores de 1820, le sucedió la leyenda de "bronce" inaugurada a fines del siglo XIX por los primeros historiadores uruguayos como conveniente revisión de la anterior... multiplicado por miles y miles gracias a la pasión por el bronce desplegada por las autoridades, emergió como elemento de orgullo y religión nacional.

As transformações político-ideológicas foram acompanhadas de mudanças na produção historiográfica porque, como afirma Yaffé (2001, p. 425, grifo do autor),

La segunda mitad del siglo XX conoció una creciente hostilidad hacia el bronce legendario (...) pero limitado a sus dotes políticas y militares. La historiografía más dinámica de los agitados años sesenta encaminó una nueva visión del artiguismo que acentuó atributos humanos del caudillo, sus preocupaciones sociales y económicas, su inclinación por los más "infelices".

Essa transformação coincidiu com a criação de uma "nueva y vigorosa identidad política: el frenteamplismo" (Yaffé, 2001, p. 412). A esquerda uruguaia se auto percebia como a autêntica superação do tradicionalismo, representado por blancos e colorados, mas a criação do frenteamplismo e sua fusão com os "outros Artigas" (social, económico, cultural, latinoamericanista), gerou uma "verdad invención de tradición" (Yaffé, 2001, 
p. 415) e um reposicionamento da esquerda no leque da cultura política nacional, abandonando a distância com as tradições, e respondendo à acusação de ser estrangeira.

"Padre Artigas, guíanos" foi o grito de encerramento do primeiro discurso de Líber Seregni como candidato do Frente Amplio, no ano de 1971, para apresentar ao artiguismo como um projeto inconcluso, que

La izquierda utilizará para proclamarse a sí misma no solo como la continuación histórica del artiguismo traicionado, sino también como síntesis y prolongación de las tradiciones blanca y batllista al tiempo que acusaba a los partidos tradicionales de haberlas abandonado y con los que la izquierda se identifica (YAFFÉ, 2001, p. 419).

Assim, a esquerda uruguaia, além de criticar e fazer oposição aos Partidos Tradicionais, tentou nacionalizar-se e tradicionalizar-se através da figura de Artigas, com um discurso de traição ou projeto inacabado. De novo, a metade da ponte, com o mesmo nome, mas com outro sentido.

Existem, assim, diversas percepções, amplamente maioritárias, e mesmo contraditórias, que situam Artigas como seu herói, seja a partir de uma perspectiva nacionalista, oficialista, militar ou de esquerda. Por isso, não resulta surpreendente que, mais de vinte anos depois da pesquisa de Cosse e Markarián (1994), em que 7 (sete) de cada 10 (dez) uruguaios consideravam erradas as críticas contra Artigas, os atuais resultados da enquete entre os estudantes seja coincidente.

Os contextos não são os mesmos: naquele momento, governava o Partido Nacional, que tentava aplicar reformas de caráter liberal na economia, quando o país ingressava no Mercosul. No ano de 2011, o Uruguai encontrava-se com um segundo governo consecutivo da Frente Amplio, desta vez liderado pelo ex-guerrilheiro, José Mujica, e um conjunto de políticas sociais de integração regional muito marcantes. E em ambos contextos, Artigas foi amplamente majoritário.

Para um jovem, integrante de uma família que votou em Mujica, em 2009, a figura de Artigas não gera rejeição, porque o Pepe autodenomina-se como artiguista, fala em Pátria Grande, em defender aos mais infelizes, etc. Mas o mesmo acontece em uma família blanca, que associa Artigas com 
o nacionalismo; ou de uma colorada, que possui um perfil mais próximo com a lenda de bronze, da imagem de Artigas prócer oficial. Isto porque a aprendizagem histórica não fica restringida às aulas escolares, e as relações e contradições entre os discursos da agenda social e política e os desafios no ensino da história escolar geram encontros e desencontros. O conceito de consciência histórica, desenvolvido por Jörn Rüsen, torna-se relevante para pensar a relação entre esse espaço público e a formação histórica escolar e, também, os vínculos entre o saber histórico e o agir cotidiano, sendo

[...] o conjunto das competências de interpretação do mundo e de si próprio, que articula o máximo de orientação do agir com o máximo de autoconhecimento, possibilitando assim o máximo de auto-realização ou de reforço identitário [...]. Formação opõe-se criticamente à unilateralidade, à especialização restritiva e ao afastamento da prática e do sujeito (RÜSEN 2007, p. 95).

Assim, a relação com os heróis e a formação histórica não podem ser pensadas como um campo fixo de orientações temporais que a pessoa tem, mas como resultado sempre inconcluso de uma construção narrativa e dialógica de cada sujeito, que questiona e reelabora os discursos oficiais e os periféricos, que disputam as narrativas do dever ser. A história ensinada e aprendida nas escolas e o pensar historicamente que os professores promovem nas escolas sobre o tempo, as identidades e as narrativas de uma história nacional e seus heróis estão em constante diálogo e, muitas vezes, contrapostos com a proposta construída com uma geração de sentido de tipo tradicional e exemplar, que

Tiende a valorar positivamente al propio grupo social, explicar sus características en términos esencialistas y no histórico, rechazar las fuentes que ponen en conflicto una versión complaciente de la propia historia, valorar en términos positivos la evolución politica del país, recuperar en forma acrítica el rol de ciertos personajes históricos emblemáticos, en muchas ocasiones a través de la dicotomía "héroes y villanos", y tender lazos de permanencia y continuidad entre los hechos y personajes del pasado y la actualidad del grupo nacional (CARRETERO; CASTORINA, 2012, p. 12, grifos dos autores).

Uma didática da História que assume os professores e os estudantes como sujeitos ativos e críticos na construção da meia ponte, relacionada com o presente e com o futuro, considera central o: 
doble movimiento de aprendizaje, el pasaje del dato objetivo a la apropiación subjetiva, $y$ de la búsqueda subjetiva de afirmación al entendimiento objetivo, alcanza el nivel o la calidad de la formación cuando consigue concretar la articulación entre objetividad y subjetividad del pensamiento histórico, característica de la historia como ciencia" (RÜSEN, 2007, p. 108).

A relação entre heróis, didática da História e consciência histórica gera desafios e reflexões relevantes para o ensino da História que, desde suas origens, esteve vinculada à produção e reprodução da identidade nacional, suspendida em um mítico presente contínuo, entre um estudante consumidor passivo e um professor reprodutor de informações.

Essa história deve ser questionada como formadora de identidades não razoáveis e míticas ${ }^{5}$, em oposição ao diálogo entre sujeitos, em palavras de Luis Fernando Cerri (2011, p. 113).

não se trata de um racionalismo cartesiano, em que a verdade está em algum lugar somente, e não está em outros, e nem um racionalismo relativista, em que a verdade, por estar com todos, não existe. Tratamos de uma razão comunicativa ou dialógica, que não é absoluta nem relativa, mas relacional, ou seja, a verdade se constitui no diálogo entre sujeitos [...].

A história e os heróis descem do pedestal para ser discutidos, debatidos e não impostos, como desejaria uma didática obediente de transmissão e absorção. Sendo assim, a perduração de Artigas pode ser entendida como uma transformação de significados, desde uma perspectiva que incorpore a dialética entre a longa duração cultural, até as transformações políticas/ geracionais recentes. Mais do que uma figura imutável, a perenidade de Artigas e suas diversas significações falam de mudanças e de continuidades.

\section{REFERÊNCIAS}

BORDABERRY, Pedro. Discurso pronunciado en el acto oficial del 19 de junio del 2002. Secretaria de prensa y difusión de la Presidencia de la ROU. 2002.

\footnotetext{
${ }^{5}$ Como ejemplo podemos recordar que en la Alemania de 1934 se publica una bibliografía de Simón Bolivar, donde en el prólogo se fija la posición de la política alemana de la época: "Justamente hoy, cuando el principio de liderazgo se ha abierto paso en Alemania, el destino de un dirigente y los conocimientos que ha adquirido durante su agitada vida el libertador y redentor de un continente, deben despertar especial interés" (WERZ, 1991, p. 104).
} 
Disponível em: http://www.presidencia.gub.uy/noticias/archivo/2002/ junio/2002061901.htm. Acesso em 24 jan. 2004.

CARRETERO, Mario; CASTORINA, José. La construcción del conocimiento histórico. Enseñanza, narración e identidades. $2^{\mathrm{a}}$ reimp. Buenos Aires, Paidós, 2012.

CERRI, Luis Fernando. Ensino da história e consciência histórica. Implicações didáticas de uma discussão contemporânea. Rio de Janeiro. Editora FGV, 2011. COSSE, Isabela; MARKARIAN, Vania. Memorias de la historia. Una aproximación al estudio de la conciencia histórica nacional. Montevideo, Ediciones Trilce, 1994.

DI GIORGI, Álvaro Sanguinetti. La otra historia del pasado reciente. Montevideo, Fin de Siglo, 2014.

DOSSE, François. O desafio biográfico. Escrever uma vida. $2^{\mathrm{a}}$ ed. São Paulo, Editor da USP, 2015.

GENTILE, Emilio. El culto del Littorio: la sacralización de la política en la Italia fascista. Buenos Aires: Siglo XXI editores, 2007.

MERCADER, Antonio. Discurso pronunciado en el acto oficial del 19 de junio del 2001. Secretaria de prensa y difusión de la Presidencia de la ROU, 2001. Disponível em: http://www.presidencia.gub.uy/noticias/archivo/2001/ junio/2001061902.htm. Acesso em: 24 jan. 2004.

MORALES, Andrés. Fútbol e identidad Rioplatense. Ediciones de la Biblioteca Nacional, Cuadernos de Historia. Montevideo, 2014.

PIÑEYRÚA, Ricardo. El fútbol y otros deportes. Ediciones del Bicentenario. Montevideo, 2014.

RILLA, José. La actualidad del pasado. Usos de la historia en la política de partidos del Uruguay (1942-1972). Debate. Montevideo, 2008.

ROSANVALLON, Pierre. Por una historia conceptual de los político. México DF. FCE, 2003. 
RÜSEN, Jorn. História viva. Teoria da história III: formas e funções do conteúdo histórico. Editora da UnB. Brasília, 2007.

VARELA, Alfonso. Discurso pronunciado en el acto oficial del 19 de junio del 2000. Secretaria de prensa y difusión de la Presidencia de la ROU, 2000. Disponível em: http://www.presidencia.gub.uy/noticias/archivo/2000/ junio/2000061901.htm. Acesso em: 24 jan. 2004.

WERZ, Nikolaus. Reflexiones sobre la imagen de Bolívar y la enseñanza de la historia en Venezuela. In: RIEKENBERG, Michael (comp.) Latinoamérica: enseñanza de la historia, libros de texto y consciencia histórica. Buenos Aires, Alianza Editorial/ Flacso/ Georg Eckert Instituts, 1991.

YAFFÉ, Jaime. La izquierda uruguaya y el pasado revolucionario oriental ¿Una leyenda roja del artiguismo?. In: FREGA, Ana e ISLAS, Ariadna. Nuevas Miradas en torno al artiguismo. Facultad de Humanidades, Universidad de la República. Montevideo, 2001. 


\section{JOVENS, IDENTIDADE E CONSCIÊNCIA DA INTEGRAÇÃO LATINO- AMERICANA}

Léia Adriana da Silva Santiago

Neste capítulo, propomos analisar os movimentos que foram ocorrendo em favor de uma integração latino-americana, desde o processo de suas independências até a consolidação do MERCOSUL, e as respostas dadas a algumas questões que foram selecionadas do questionário aplicado aos alunos nas distintas escolas e regiões do Brasil. Neste sentido, intencionamos verificar, nas respostas dadas pelos alunos brasileiros, se estas tentativas de integração foram contribuindo, no ensino de História da Educação Básica, para a construção de uma integração regional, para a formação de uma identidade mais global ou regional, e uma consciência histórica e cidadã, uma vez que esta é "a suma das operações mentais com as quais os homens interpretam sua experiência da evolução temporal de seu mundo e de si mesmos, de forma tal que possam orientar, intencionalmente, sua vida prática no tempo" (RÜSEN, 2001, p. 51).

Assim, nas linhas que seguem, apresentamos as distintas tentativas de integração entre os países latino-americanos e, posteriormente, expomos os resultados obtidos pelas respostas dos alunos.

\section{AS PROPOSTAS DE INTEGRAÇÃO LATINO-AMERICANA E O ENSINO DE HISTÓRIA NO CONTEXTO DO MERCOSUL}

A história da América Latina pós-independência carrega sinais de tentativas de cooperação ou integração entre seus países. Desde o século XIX, período de lutas pelas independências, a ideia de uma matriz integracionista latino-americana foi fundada por libertadores, como Simón Bolívar, Miranda e O'Higgins, ao redor das batalhas revolucionárias, que almejavam se libertar dos colonizadores espanhóis e portugueses (SARAIVA, 1995). Essa ideia de liberdade parece não ter sido entendida de uma única forma pelos homens que lideraram os processos de rupturas com o sistema colonial ibérico. Para Simón Bolivar, principal articulador das independências na 
América do Sul, essa liberdade era sinônimo de rompimento com a Espanha, para a criação de nações livres que, unidas em uma confederação, pudessem assegurar os ideais de liberdade e independência. Para Dessalines, líder da revolução escrava no Haiti, a liberdade representava o fim da escravidão. Para outros dominados e oprimidos, como os índios no México, por exemplo, a liberdade passava muito longe da Espanha e muito próxima à questão do direito sobre a terra (PRADO, 1986).

O Brasil, recém-saído da independência e ansioso por construir seu projeto de Estado e Nação, buscou afirmação internacional por meio do reconhecimento da independência.

A jovem nação brasileira desejou afastar-se moderadamente do velho continente, aproximando-se das nações americanas. No entanto, o processo de aproximação com as repúblicas sul-americanas foi caracterizado por surtos de maior ou menor intensidade.

O primeiro e segundo reinados seguiram padrão isolacionista. Esse isolacionismo ocorreu, especialmente, por prevenção dos países vizinhos, distanciados do Brasil pela forma de governo, obstáculos de linguagem, assim como pela recordação da política expansionista do sistema lusitano.

Havia, também, outro fator que agravava este distanciamento entre os países latino-americanos: entre eles existia pouca unidade de propósitos, pois eram escassas as possibilidades de cooperação econômica entre regiões e países especializados em poucas matérias-primas de exportação.

Com a república, o conceito unitário continental deixava o terreno do igualitarismo latino-americano para transformar-se em um sistema de estados sob a liderança, especialmente no campo econômico, dos Estados Unidos.

No entanto, ao final das guerras mundiais, foram surgindo organismos como a Organização das Nações Unidas - ONU e suas organizações (Organização das Nações Unidas para a Educação, Ciência e CulturaUNESCO; Fundo das Nações Unidas para a Infância - UNICEF; e o Fundo Monetário Internacional - FMI). 
Como consequência disto, em julho e agosto de 1947, na reunião do Conselho Econômico e Social da ONU, aparece o tema da criação de uma Comissão Econômica para a América Latina. Frente ao surgimento deste tema durante a reunião, em primeiro de agosto de 1947, é apresentada a proposta efetiva de criação da Comissão Econômica para a América Latina - CEPAL, que foi aprovada em fevereiro de 1948.

Integrando todos os países do hemisfério, com participação também dos Estados Unidos, Alemanha, Coreia, Grã-Bretanha, França, Holanda e Itália, com sede no Chile, a CEPAL estende sua atividade até a época presente. Esta Comissão tinha como objetivo a criação de um pensamento latino-americano que fosse autônomo em relação às Teorias Clássicas de Comércio Internacional ${ }^{1}$. Segundo ela, a desarmonia existente entre os países desenvolvidos e subdesenvolvidos configurava um padrão de dependência destes últimos na economia mundial. Para a CEPAL, a superação dessas condições desarmônicas deveria passar por uma mudança estrutural das economias, consideradas periféricas (SILVA, 2005).

Com o fim da Segunda Guerra Mundial, o governo argentino passou a priorizar o relacionamento com seus países vizinhos, porque seu objetivo era conformar uma união política e alfandegária na América do Sul, centrada no Cone Sul. Para isto, Perón necessitava primeiramente integrar-se ao Brasil ${ }^{2}$ para, posteriormente, se integrar aos demais países da América do Sul e, em seguida, à América Latina.

Assim, Perón buscou articular acordos, com o propósito de estreitar laços com seus vizinhos, especialmente com o Brasil. Em 1948, ele apresentou aos governos do Brasil, do Chile, do Peru e da Bolívia uma proposta de união alfandegária denominada de Bloco Austral, à qual o Brasil, sob a presidência de Eurico Gaspar Dutra, opôs-se veementemente (LEME, 2006).

\footnotetext{
${ }^{1}$ As teorias clássicas foram fundadas por Adam Smith e David Ricardo e formuladas como uma crítica ao "sistema mercantil", ou seja, "precisamente ao sistema no qual os governos trataram as economias nacionais como conjuntos a serem desenvolvidos pelos esforços e políticas estatais. O livre-comércio e o livre-mercado se dirigiam precisamente contra esse conceito de desenvolvimento econômico nacional, que Smith acreditava ter demonstrado ser contraprodutivo" (HOBSBAWN, 2008, p. 38). ${ }^{2}$ Perón entendia que a integração com o Brasil constituía uma etapa fundamental para que fosse atingida uma integração na América do Sul.
} 
O retorno de Getúlio Vargas à presidência do Brasil colocou na pauta destes dois países a ideia da formação de um eixo argentino e brasileiro, já com a participação do Chile. Vargas mostrou-se simpático à tentativa de um novo acordo, que teve como objetivo a formação de uma união aduaneira e política entre Argentina, Brasil e Chile. (LEME, 2006)

No entanto, Vargas encontrou forte oposição a respeito dessa intensificação nas relações com a Argentina e a assinatura deste novo acordo. A reação de setores do governo, da impressa e da classe empresarial foi imediata, alegando existirem intenções hegemônicas no projeto de Perón. Esta oposição resultou no afastamento das relações do Brasil com os outros dois países, e no enfraquecimento do presidente Vargas (LEME, 2006).

Com a ascensão de governos democratizados na América Latina, eles passaram a apregoar uma proposta de autonomia em relação ao desenvolvimento econômico, que não era vista com bons olhos pelos Estados Unidos. Assim, Juscelino Kubitschek lançou, em 1958, um projeto que propunha a revisão do pan-americanismo, denominado de Operação Pan-Americana - OPA. Esta tinha como diretrizes a intensificação do investimento em áreas economicamente atrasadas do Continente, a proteção dos preços dos produtos de base contra as excessivas flutuações, a criação de programas de assistência técnica para a melhoria da produtividade e a atualização necessária dos organismos financeiros internacionais para a ampliação de seus recursos. Estas diretrizes foram discutidas em uma reunião em nível político do Continente e gerou a criação do Comitê dos $21^{3}$, com o consentimento dos Estados Unidos. (SILVA, 2005)

A proposta da OPA foi bem recebida pelos países latino-americanos, embora houvesse o temor de ficarem sob a dependência de uma aliança entre o Brasil e os Estados Unidos. Também foi por intermédio desta operação que se formalizaram decisões conjuntas, como a criação da Associação Latino-americana de Livre Comércio - ALALC, e o encontro de Uruguaiana, em 1961, no qual foram firmados vários acordos entre Brasil e Argentina (SILVA, 2005).

\footnotetext{
${ }^{3}$ Formado por 21 Repúblicas Americanas.
} 
A ALALC, conforme descrito por Momma (2001), teve origem em 1961, a partir de entendimentos entre o Brasil, a Argentina, o Chile e o Uruguai em relação ao estímulo à complementação econômica dos países do Cone Sul e a criação de um mercado comum. Participavam da ALALC todos os países sul-americanos, com exceção das Guianas. Esse acordo tinha como objetivo estimular a industrialização e a diversificação das economias dos países latino-americanos, a redução de sua dependência dos países mais industrializados e visava à constituição de uma zona de livre comércio ${ }^{4}$ em um prazo de doze anos. Essa associação teve a vigência de 20 anos; porém, sem resultados significativos, pelo fato de que todos queriam abrir os mercados dos demais para seus produtos, mas ninguém queria abrir seu próprio mercado para ninguém. No final da década de 1970, os países participantes da ALALC negociaram um novo tratado, menos ambicioso e mais flexível, a Associação Latino-Americana de Integração - ALADI.

Inaugurada em agosto de 1980, com o Tratado de Montevidéu, a ALADI teve como objetivo a total liberalização do comércio entre seus onze países-membros ${ }^{5}$. Mesmo se apresentando como um acordo modesto, ele foi tido como um projeto bastante frágil, devido às disparidades existentes entre os países envolvidos, tanto em relação ao desenvolvimento econômico como pela condução de suas políticas.

Com a instauração dos regimes militares, o processo de integração enfrentou dificuldades. Os planos nacionais de desenvolvimento econômico, apregoados pelos regimes militares no Brasil e na Argentina, possuíam uma acentuada tendência autonomista, que inibiu qualquer proposta de integração regional (LEME, 2006).

Deste modo, as tentativas de uma integração latino-americana, vistas até a instauração dos regimes militares, na década de 1970, estiveram quase que exclusivamente restritas às questões políticas e econômicas, não apresentando sinais de uma integração que incluísse as questões culturais e educacionais. Foram

\footnotetext{
${ }^{4} \mathrm{~A}$ zona de livre comércio propõe eliminar as barreiras tarifárias e não-tarifárias que incidem sobre o comércio dos produtos, permitindo o livre fluxo do comércio entre os países integrantes do acordo (MOMMA, 2001).

${ }^{5}$ Integravam a ALADI: Bolívia, Colômbia, Equador, Peru, Venezuela, Argentina, Brasil, Paraguai, Uruguai, Chile e México (MOMMA, 2001).
} 
tentativas que não surgiram da sociedade civil, expressando-se através das forças politicas, mas surgiram quase que exclusivamente das entranhas do Estado.

Estas tentativas também mostraram que havia elementos de desconfiança ${ }^{6}$ nas relações entre o Brasil e os demais países, que geraram dificuldades em manter um processo contínuo de integração. Neste sentido, é possível pensar que a preocupação que se acentuou com a questão do nacionalismo no Brasil, ao final do século XIX e decorrer do século XX, também pode ter cooperado para o distanciamento deste com os demais países. Até mesmo no contexto da sala de aula, pesquisas têm apontado que o estudo da América Latina resumia-se a alguns tópicos de um extenso programa da história das civilizações (SANTIAGO, 2012).

Todavia, quando se pensa na construção do MERCOSUL, este teve fatores que favoreceram a sua formação e a inclusão do tema da Educação para os países que compunham o bloco.

Em 1991 nascia oficialmente o Mercado Comum do Sul - MERCOSUL, fruto de um novo processo de aproximação iniciado com Brasil e Argentina; da abertura dos mercados internos dos países periféricos; da redemocratização dos países latino-americanos e da vulnerabilidade destes países, se continuassem isolados. (SANTIAGO, 2012)

Vigevani e Ramanzini Jr (2009) descrevem que as posições do Estado brasileiro em relação ao processo de integração do Cone Sul foram e seguiram no governo de Luis Inácio Lula da Silva e Dilma Rousseff, relacionadas a um real interesse pela integração, mas este interesse não esteve desvinculado do objetivo de garantir melhores condições de inserção em outras arenas internacionais. A projeção externa do Brasil tem sido perseguida mediante intensa participação em foros políticos e econômicos, regionais e multilaterais, na busca de preservação do país ante os riscos de vulnerabilidade, e na tentativa de aumentar o próprio poder e se posicionar em distintos tabuleiros, globais ou regionais, com distintas posturas, tal como ocorreu

\footnotetext{
${ }^{6}$ Saraiva (1995) observa que um dos elementos de desconfiança fazia lembrar a suspeita de Simón Bolivar em relação ao Brasil, quanto ao fato de que o império brasileiro, sendo regido pelo filho do rei de Portugal, D. Pedro I, podia significar a persistência das ideias de recolonização da Santa Aliança em território americano.
} 
com a formação do MERCOSUL e, posteriormente, da União das Nações Sul-americanas - UNASUL.

Assim, com o nascimento do MERCOSUL, a necessidade de integração, não somente econômica, também política, social e cultural, foi se tornando cada vez mais emergente. Estas políticas de integração, em outros âmbitos, foram sendo justificadas pela urgência de investimento estratégico na formação de recursos humanos e pela integração cultural e científica através do intercâmbio entre os distintos países, o que, necessariamente, não excluiu o viés econômico (RAIZER; FACHINETO; NEVES, 2006).

Deste modo nascia, ainda no ano de 1991, o Setor Educacional do MERCOSUL (SEM), que considerava, entre outros aspectos,

- Que a Educação tem um papel fundamental para que esta integração se consolide e se desenvolva;

- Que a herança cultural dos povos latino-americanos e, particularmente, dos Estados Membros do MERCOSUL, é comum;

- Que o fator humano e a qualidade dos habitantes da Região constituirão uma sólida garantia de êxito no processo de integração:

- Que para fortalecer a ampliação das atuais dimensões de seus mercados nacionais, a livre circulação de bens, serviços e fatores de produção, é fundamental considerar a Educação como elemento dinamizador que permitirá acelerar os processos de desenvolvimento econômico com justiça social e consolidar o caminho da integração;

- Que da Educação depende, em grande parte, da capacidade dos povos latino-americanos de se reencontrarem nos valores comuns e na afirmação de sua identidade ante os desafios do mundo contemporâneo (BRASIL, 1991, p. 1).

Com estes objetivos em pauta, o SEM foi estabelecendo, desde 1992, planos de ação que incluíam propostas para o ensino de História e Geografia nas escolas do MERCOSUL. Estas propostas foram discutidas em seminários bienais do ensino de História e Geografia, ocorridos entre os anos de 1997 a 2002.

Das discussões trazidas pelos especialistas nestes seminários, existiu um consenso de que os conteúdos de América Latina, no ensino de História dos países signatários do MERCOSUL, devem valorizar o que há de comum 
em suas trajetórias, para possibilitar a identificação de traços identitários comuns e favorecer o processo de integração regional. Os discursos também manifestaram os impasses entre a troca de paradigmas, que permite o enfoque histórico centrado na América Latina, e a inclusão de conteúdos no interior de uma história geral, que não pode mais ser ensinada apenas a partir do ponto de vista da Europa. Como eixos comuns para o desenvolvimento dos conteúdos históricos específicos em cada país, foi definido o estudo da história das sociedades e das culturas indígenas americanas, a diversidade cultural e os aspectos comuns, a construção da democracia e o processo de integração na região.

Além dos eixos, outros conteúdos foram expostos nos discursos proferidos pelos especialistas, no decorrer dos seminários. Estes conteúdos foram: Fronteiras como espaço de intercâmbio e isolamento; passado colonial na perspectiva dos estudos comparados; os conflitos entre Estados nacionais em uma perspectiva regional; as ditaduras militares recentes e os circuitos de exílio; a produção cultural em uma perspectiva histórica; a Educação Patrimonial; a destruição das formas de vida dos indígenas e o aparecimento de novos conceitos, como conquista, cristianismo e aculturação; a entrada dos países americanos no mercado mundial como provedores de matéria-prima; o surgimento da burguesia industrial e da classe operária; o populismo; a abertura para o capital estrangeiro e a dívida externa; globalização (economia mundializada e o retorno à democracia).

Entretanto, a despeito do que tem sido trabalhado pelo MERCOSUL Educacional, desde o ano de 1992, no intuito de aprovar uma proposta curricular de História que tenha o enfoque regional e que contribua na construção de uma identidade regional, pesquisas já realizadas com currículos, livros didáticos e professores têm apontado para a veiculação de poucos conteúdos, limitando-se especialmente ao estudo do passado latino-americano vinculado à história europeia.

\section{OS JOVENS E A AMÉRICA LATINA}

Quando consideramos as respostas dadas pelos alunos ao questionário, percebemos que ainda há, entre eles, a compreensão de que o 
maior objetivo da História é o conhecimento do passado. Este objetivo dá à História o significado de que ela explica os problemas atuais, ou assinala uma forma de entender a minha vida como parte das mudanças. Entretanto, ao contrário do esperado, os estudantes demonstraram que os objetivos de compreender o presente e orientar para o futuro, no estudo da História, carregam praticamente a mesma relevância que o objetivo de conhecer o passado. Ao menos em nível declaratório ou em termos de expectativas, os respondentes indicam uma concepção de utilidade da História em que o conhecimento do passado integra-se às dimensões presente e futura nos objetivos da disciplina.

Tabela 1 - Respostas dos estudantes à questão 2 do instrumento de coleta de dados

\section{Em sua opinião, qual a importância de cada um dos seguintes objetivos ao se estudar a história *:}

\begin{tabular}{l|l|l}
\hline & Respostas válidas & Média Geral \\
\hline a) Conhecer o passado & 2364 &, 99 \\
\hline b) Compreender o presente & 2375 &, 93 \\
\hline c) Buscar orientação para o futuro & 2380 &, 81 \\
\hline
\end{tabular}

Fonte: Projeto Jovens e a História no MERCOSUL (2013). Elaboração da autora.

* Respostas transformadas em escala numérica: Muito pouca importância $=-2$; pouca importância $=-1$; mais ou menos $=0$; importante $=1$ e muito importante $=2$.

Os resultados da tabela 1 podem ser interpretados praticamente como uma convocação dos alunos por um ensino de História que articule o conhecimento do passado com a reflexão sobre o presente e o futuro. Nesta perspectiva, se olharmos as pesquisas realizadas no Brasil por Dias (2004), Silva (2006), Koling (2008) e Santiago (2012), os livros didáticos, nos currículos e em entrevistas com professores, sobre os conteúdos referentes à América Latina, a partir da década de 1950 e posteriormente à formação do MERCOSUL, vemos que os conteúdos veiculados se mantêm tematizando o passado, com o contato dos povos americanos e os hispânicos, no final do século XV e XVI; a América colonial, entre os séculos XVI ao XVIII; e os processos de independência da América Latina, no século XVIII. A escassez de articulação com a história recente, entretanto, pode ser um fator que empurra para baixo o interesse dos alunos. As respostas 
também sinalizam que é justamente para os períodos entre 1500 e 1800, entre os séculos XV a XVII, que aparece o menor interesse dos alunos (tabela 2). Cumpre observar que não se trata de desinteresse, mas de menor interesse médio, ou seja, uma média próxima de zero indica uma distribuição equilibrada entre indiferença, interesse e desinteresse, como se pode verificar no gráfico 1 .

Gráfico 1 - Histograma das respostas à questão Qual é o seu interesse nos seguintes períodos da história?*

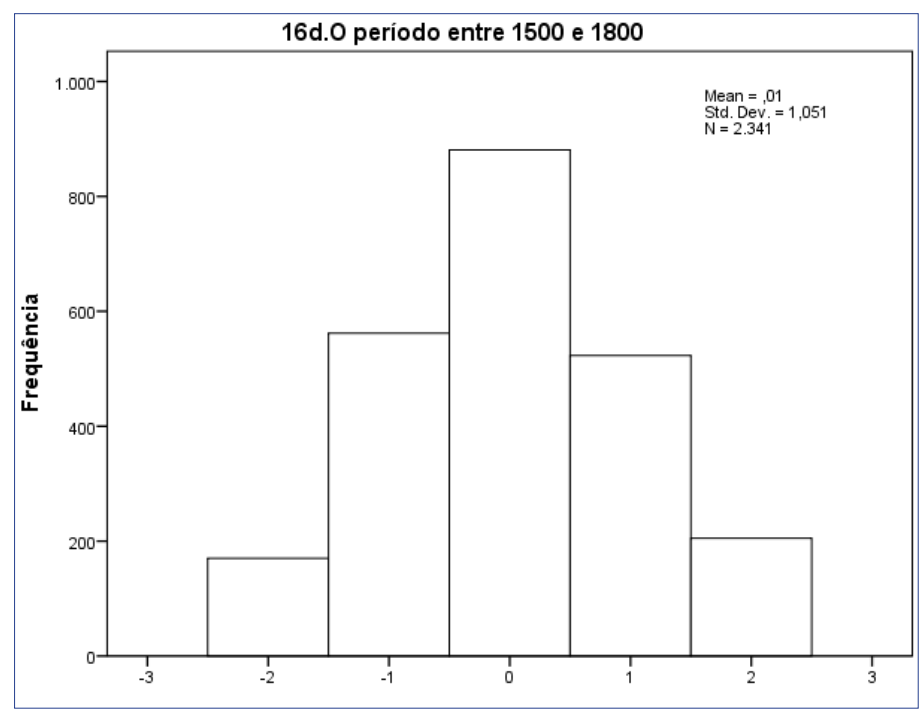

Fonte: Projeto Jovens e a História no MERCOSUL (2013). Elaboração da autora.

$*$ Legenda do eixo $\mathrm{x}$ : nenhum $=-2 ;$ pouco $=-1$; médio $=0$; grande interesse $=1$ e interesse total $=2$

Esta curva de interesses por períodos da História vista abaixo, na tabela 2, mantém o mesmo desenho em todas as amostras nacionais, e tende a manter-se, mesmo quando os dados são desagregados por variáveis diversas, como sexo, tipo de escola, maior ou menor interesse, ou opinião sobre a utilidade da disciplina História (ver CERRI, 2016). Em suma, esse pode ser um fator que interfere negativamente no interesse dos estudantes pelos assuntos de História da América, que normalmente são oferecidos pelo currículo escolar, o que, por sua vez, pode estar entre os fatores que, somados, explicam as dificuldades culturais nos processos de integração em curso. 
Tabela 2 - Respostas dos estudantes à questão 16 do instrumento de coleta de dados

16. Qual seu interesse pelo seguinte período da história *:

\begin{tabular}{l|l|l}
\hline & Respostas válidas & Média \\
\hline a) A origem dos seres humanos & 2372 &, 34 \\
\hline b) Mundo antigo & 2349 &, 22 \\
\hline c) Idade Média (aprox. de 500 a 1500) & 2351 &, 13 \\
\hline d) O período entre 1500 e 1800 & 2341 &, 01 \\
\hline e) O período entre 1800 a 1945 & 2345 &, 17 \\
\hline f) De 1945 até os dias de hoje & 2359 &, 65 \\
\hline
\end{tabular}

Fonte: Projeto Jovens e a História no MERCOSUL (2013). Elaboração da autora.

* Respostas transformadas em escala numérica: nenhum $=-2$; pouco $=-1$; médio $=0$; grande interesse $=1$ e interesse total $=2$.

Contudo, cabe ainda observar que este menor interesse dos alunos pelos assuntos relacionados à História da América persiste em outras questões levantadas, como é o caso da questão 18 (tabela 3). Nela, por um lado, está exposta que a menor porcentagem de interesse de estudos refere-se aos outros países da América Latina, embora, dentro da escala Likert, a média incida sobre médio interesse. Por outro lado, o estudo da história do mundo, excluindo a América Latina, assim como a história nacional, aparece com resultados médios próximos à resposta, grande interesse. Tais fatos presentes nas respostas podem estar relacionados à construção de uma memória, inclusive escolar, que insistiu no distanciamento entre o Brasil e os países hispano-americanos e caribenhos, pela necessidade de erigir e fortalecer urna identidade nacional, que levou muitos historiadores, cientistas sociais e ensaístas a reforçar as nossas diferenças em relação aos demais países americanos. Neste sentido, o sistema educativo, em geral, e a História, em particular, apareceram como peças essenciais do mecanismo construído para consolidar o Estado. Petitat (1994, p. 163), observa que a nação e o cidadão são forjados na escola, porque a estatização do ensino "acarreta uma transformação nos temas de referência ideológicos e culturais, que passam a ser o elogio da pátria, história e geografia nacionais, história dos costumes nacionais e das virtudes exemplares". Assim, este distanciamento, de certa maneira, foi incorporado pela sociedade 
brasileira, que tem mantido, como latino-americanos, uma identificação fluida, variável, mais ou menos presente, dependendo das circunstâncias e do momento histórico.

Para Baggio (2001), não há dúvida de que as diferenças são, em geral, mais destacadas do que as similitudes. "A América Hispânica - vista a partir de olhares brasileiros - é uma 'outra' América, ainda que façamos parte deste todo complexo e contraditório denominado América Latina" (BAGGIO, 2001, p. 18).

Tabela 3 - Respostas dos estudantes à questão 18 do instrumento de coleta de dados

\section{Qual seu interesse sobre a história dos seguintes lugares *:}

\begin{tabular}{l|l|c}
\hline & Respostas válidas & Média \\
\hline a) A história da localidade onde vivo & 2378 &, 08 \\
\hline b) A história da minha região & 2377 &, 19 \\
\hline c) A história do Brasil & 2372 &, 53 \\
\hline d) Outros países da América Latina & 2362 &, 04 \\
\hline e) A história do mundo, excluindo a América Latina & 2378 &, 39 \\
\hline
\end{tabular}

Fonte: Projeto Jovens e a História no MERCOSUL (2013). Elaboração da autora.

* Respostas transformadas em escala numérica: nenhum $=-2$; pouco $=-1$; médio $=0$; grande interesse $=1$ e interesse total $=2$.

Neste distanciamento do Brasil com os demais países da América Latina, coube observar, na questão 17 (tabela 4), que as guerras e as ditaduras e a cultura dos países distantes estão entre os temas da História que mais interessam aos alunos. A resposta a respeito das ditaduras não evidencia claramente se esta se refere ao circuito das ditaduras presentes na América Latina. Contudo, o estudo das culturas distantes parece novamente sinalizar para esta memória que distanciou o Brasil dos seus vizinhos, como também mostra que as tentativas de integração realizadas ao final do século XIX e ao longo do século XX, não serviram de estímulo para a troca de conhecimentos culturais, ou mais especificamente, de uma integração cultural.

Para além das próprias tentativas de integração, que pouco serviram como elemento de aproximação cultural entre os países, o professor, no 
interior da sala de aula, pouco pode contar, no Brasil, com um entorno cultural, jornalístico, midiático e informal para complementar seu ensino sobre a América Latina. Da diversidade de elementos que, em História, se imbricam em seu ensino, como os valores e as representações da cultura de massa, o professor é extremamente carente. A carência deste ou de outros elementos inseridos no ensino que o professor veicula, interfere, de certa maneira, nas escolhas e nos interesses dos alunos.

Tabela 4 - Respostas dos estudantes à questão 17 do instrumento de coleta de dados

\section{Qual seu interesse pelos seguintes temas da história:}

\begin{tabular}{l|l|l}
\hline & Número Válido & Média Geral \\
\hline a) A vida cotidiana das pessoas comuns & 2375 &,- 28 \\
\hline $\begin{array}{l}\text { b) Reis, presidentes e personagens politicamente } \\
\text { importantes no poder }\end{array}$ & 2382 &, 18 \\
\hline c) Aventureiros e grandes descobridores & 2360 &, 53 \\
\hline d) Guerras e ditaduras & 2355 &, 65 \\
\hline e) Culturas de países distantes & 2355 &, 53 \\
\hline f) formação das nações & 2360 &, 22 \\
\hline g) O desenvolvimento da democracia & 2347 &, 05 \\
\hline h) A interferência do homem no meio-ambiente & 2357 &, 37 \\
\hline $\begin{array}{l}\text { i) O desenvolvimento da agricultura, da indústria } \\
\text { e do comércio }\end{array}$ & 2355 &, 09 \\
\hline j) história de assuntos específicos (por exemplo: a & 2369 &, 40 \\
\hline história dos carros, da Igreja, da música, etc.) & 2365 \\
\hline k) A história da sua família & 2360 &, 83 \\
\hline
\end{tabular}

Fonte: Projeto Jovens e a História no MERCOSUL (2013). Elaboração da autora.

* Respostas transformadas em escala numérica: muito pouca $=-2$; pouca $=-1 ;$ média $=0$; importante $=1$ e muito importante $=2$.

Neste sentido, como observa Souza (2006, p. 5), a respeito dos estudos sobre a América Latina, no ensino de História,

a dificuldade de inclusão da América Latina nos conteúdos de ensino advém desse distanciamento que temos em relação aos contextos sócio-político-cultural dos países do continente. Não se trata apenas da forma acanhada como o currículo acadêmico trata o continente americano, embora isso contribua muito para o silêncio e o esquecimento a respeito do assunto. É um distanciamento enorme, agregado a um desprestígio a respeito desses países e dessas sociedades; 
um pessimismo acentuado a respeito da superação das dificuldades econômicas e políticas; uma ignorância sobre as possibilidades e potencialidade dos mesmos. A América Latina adentra, em parte, no rol de informação que circula no Brasil, na condição de áreas de exotismo e desgoverno político.

Considerando que o conhecimento histórico escolar é geral e formativo, o seu ensino, ao ser realizado no espaço escolar, não depende somente da boa vontade do professor, mas ele resvala nas questões curriculares, nas abordagens teóricas da ciência de referência, no mercado editorial, nas mídias em geral e em uma cultura que permita apreciar a identidade latino-americana em sua positividade, questionamos: para o que vêm servindo as distintas tentativas de integração que o Brasil tem realizado com os países vizinhos? Como tais tentativas de integração têm contribuído para uma perspectiva latino-americana no ensino de História, ante o predomínio de uma abordagem eurocêntrica? Como as próprias perspectivas de integração têm se construído no ensino de História?

Finocchio (1998), no primeiro seminário de especialistas no ensino de História e Geografia, do MERCOSUL Educacional, realizado em 1997, já questionava de que maneira o ensino de História poderia contribuir para a democratização da integração, em termos culturais. Neste sentido, como resposta a esta pergunta, a própria autora considerava a importância de refletir a respeito da função da História no contexto do MERCOSUL; de divulgar o que estava sendo produzido de conhecimentos históricos sob uma perspectiva regional; de definir conteúdos escolares que fossem legitimados por essa produção; e de advertir sobre os problemas com a circulação de livros e o estado de pobreza das bibliotecas em relação a esta temática.

Tal questionamento colocado por Finochio (1998), há vinte anos, parece que ainda precisa ser pensado e refletido pelo próprio MERCOSUL e atualmente pela UNASUL. Entretanto, não podemos deixar de observar que, entre as muitas idas e vindas dos processos de integração que o Brasil participou, as transformações recentes vivenciadas por ele e por outros países latino-americanos configuraram um alinhamento político à direita, e tornaram manifesto um fascismo xenofóbico, uma cultura individualista e um ódio de classe, difundido pela grande mídia e pela internet (BAROM, 2017). 
Se esta configuração, iniciada pelos anos de 2013, dará novos rumos ao processo de integração, esperamos que ela proporcione canais de aproximações culturais, que possibilitem, ao aluno, conhecer ou reconhecer $o$ que está moda na Argentina, o que aconteceu na Bolivia, o personagem de uma novela colombiana, um filme chileno, uma música peruana, a capa de um livro com uma imagem olmeca, um templo maia, um escritor cubano, o calendário asteca, um prato mexicano. Contrariando algumas percepções postas nas linhas anteriores, o que vemos como resultado da questão 40 (tabela 5), ao tratar da importância dos processos de integração da América do Sul, aproxima de grande interesse, dentro da escala Likert, os Programas que facilitem que os cidadãos estudem e trabalhem em outros países da região e as Iniciativas que deem mais acesso a livros, filmes e músicas produzidas em outros países da América do Sul.

Tabela 5 - Respostas dos estudantes à questão 40 do instrumento de coleta de dados

\section{Sobre os processos de integração da América do Sul, que importância tem o seguinte*:}

\begin{tabular}{l|l|l}
\hline & Respostas válidas & Média \\
\hline $\begin{array}{l}\text { a) Acordos para aumentar o comércio entre os } \\
\text { países. }\end{array}$ & 2293 &, 67 \\
\hline $\begin{array}{l}\text { b) Programas que facilitem que os cidadãos estudem } \\
\text { e trabalhem em outros países da região. }\end{array}$ & 2290 &, 86 \\
\hline $\begin{array}{l}\text { c) Construção de estradas, ferrovias, gasodutos e } \\
\text { obras que conectem os países do continente. }\end{array}$ & 2274 &, 62 \\
\hline $\begin{array}{l}\text { d) Iniciativas que promovam uma integração mais } \\
\text { solidária entre os povos da região. }\end{array}$ & 2283 &, 66 \\
\hline $\begin{array}{l}\text { e) Iniciativas que deem mais acesso a livros, filmes } \\
\text { e músicas produzidas em outros países da América } \\
\text { do Sul. }\end{array}$ & 2277 &, 70 \\
\hline
\end{tabular}

Fonte: Projeto Jovens e a História no MERCOSUL (2013). Elaboração da autora.

* Respostas transformadas em escala numérica: muito pouca $=-2 ;$ pouca $=-1 ;$ média $=0$; importante $=1$ e muito importante $=2$.

A presença de pouco interesse, médio interesse e grande interesse nas respostas dadas pelos alunos parece evidenciar as próprias dificuldades que 
o MERCOSUL, a UNASUL e a comunidade epistêmica encontram, sobre o que dizer a respeito da história da América Latina que deve ser ensinada.

Contudo, tal questão ainda está distante de uma síntese, especialmente quando vemos as ideias que os alunos têm sobre as nações e o país, e o fato de que estes devem ceder parte da sua soberania a organismos internacionais (como a ONU, o MERCOSUL), presentes na resposta 36 (tabela 6).

Tabela 6 - Respostas dos estudantes à questão 36 do instrumento de coleta de dados

36. Que ideias você tem sobre as nações e o país? *

\begin{tabular}{l|l|l}
\hline & Respostas válidas & Média \\
\hline $\begin{array}{l}\text { a) As nações nascem, crescem e morrem na } \\
\text { História, como acontece com tudo. }\end{array}$ & 2309 &,- 14 \\
\hline $\begin{array}{l}\text { b) As nações são coisas naturais por uma origem, } \\
\text { por uma língua, pela história e pela cultura. }\end{array}$ & 2298 &, 51 \\
\hline $\begin{array}{l}\text { c) As nações são o desejo da criação de um futuro, } \\
\text { apesar das diferenças culturais do passado. }\end{array}$ & 2293 &, 47 \\
\hline $\begin{array}{l}\text { d) Os países devem ceder parte da sua soberania } \\
\text { a organismos internacionais (como a ONU, o } \\
\text { MERCOSUL). }\end{array}$ & 2282 &, 14 \\
$\begin{array}{l}\text { e) Os interesses do meu país devem ser defendidos a } \\
\text { todo custo, inclusive por força militar. }\end{array}$ & 2289 &, 10 \\
\hline
\end{tabular}

Fonte: Projeto Jovens e a História no MERCOSUL (2013). Elaboração da autora.

* Respostas transformadas em escala numérica: muito pouca $=-2$; pouca $=-1$; média $=0$; importante $=1$ e muito importante $=2$.

As respostas na média encontram-se dentre da faixa de concordância parcial. O detalhamento desses resultados aponta que predomina, entre os estudantes, uma concepção romântica de nação, entendendo que ela resulta de forças naturais, telúricas ou espirituais pouco ligadas à vontade humana ou à capacidade de optar politicamente, como povo. As razões para essa predominância dependem de um estudo à parte para serem delimitadas com clareza, mas é possível identificar, nas respostas da tabela 6, que a visão da nação como um resultado da natureza (afirmação 36b) sobrepõe-se à ideia de nação histórica com começo, meio e fim (afirmação 36a). Pode-se sustentar a hipótese de que esta visão está ligada ao modo como se ensina a História, na qual o enfoque ou o quadro narrativo estão desenhados 
de modo nacional, como se essa fosse uma categoria pré-existente, que nunca é problematizada. Assim, é mais fácil encontrar a explicação de que os índios foram os primeiros habitantes do Brasil, do que a explicação de que os índios estavam aqui antes que o Brasil fosse criado pelo processo histórico cheio de possibilidades e caminhos variados, dentre os quais resulta o país como o conhecemos.

A concepção da nação como um resultado natural, cujo desenrolar, de certo modo, supera o protagonismo da ação humana, política e histórica, está relacionada a admitir a cessão de parte da soberania a organismos internacionais ou, em outros termos, a relativização da predominância absoluta do interesse nacional, conforme se demonstra na Tabela 7.

Tabela 7 - Cruzamento entre as respostas às afirmações 36a e 36d

\begin{tabular}{|c|c|c|}
\hline \multicolumn{3}{|c|}{$\begin{array}{l}\text { 36a. As nações nascem, crescem e morrem na História, como acontece com } \\
\text { tudo X 36d. Os países devem ceder parte da sua soberania a organismos } \\
\text { internacionais (como a ONU, o MERCOSUL) }\end{array}$} \\
\hline & & $\begin{array}{l}\text { Percentual } \\
\text { válido }\end{array}$ \\
\hline \multirow{5}{*}{$\begin{array}{l}\text { Discordo } \\
\text { totalmente } \\
\text { que as nações } \\
\text { nascem, crescem } \\
\text { e morrem na } \\
\text { História, (...) }\end{array}$} & $\begin{array}{l}\text { Discordo totalmente que os países devem ceder parte da } \\
\text { soberania }\end{array}$ & 10,4 \\
\hline & Discordo que os países devem ceder parte da soberania & 19,1 \\
\hline & $\begin{array}{l}\text { Concordo em parte que os países devem ceder parte da } \\
\text { soberania }\end{array}$ & 32,8 \\
\hline & Concordo que os países devem ceder parte da soberania & 21,9 \\
\hline & $\begin{array}{l}\text { Concordo totalmente que os países devem ceder parte da } \\
\text { soberania }\end{array}$ & 15,8 \\
\hline \multirow{5}{*}{$\begin{array}{l}\text { Discordo que } \\
\text { as nações } \\
\text { nascem, crescem } \\
\text { e morrem na } \\
\text { História, (...) }\end{array}$} & $\begin{array}{l}\text { Discordo totalmente que os países devem ceder parte da } \\
\text { soberania }\end{array}$ & 3,9 \\
\hline & Discordo que os países devem ceder parte da soberania & 25,2 \\
\hline & $\begin{array}{l}\text { Concordo em parte que os países devem ceder parte da } \\
\text { soberania }\end{array}$ & 40,2 \\
\hline & Concordo que os países devem ceder parte da soberania & 23,6 \\
\hline & $\begin{array}{l}\text { Concordo totalmente que os países devem ceder parte da } \\
\text { soberania }\end{array}$ & 7,1 \\
\hline \multirow{4}{*}{$\begin{array}{l}\text { Concordo } \\
\text { que as nações } \\
\text { nascem, crescem } \\
\text { e morrem na } \\
\text { História, (...) }\end{array}$} & $\begin{array}{l}\text { Discordo totalmente que os países devem ceder parte da } \\
\text { soberania }\end{array}$ & 3,3 \\
\hline & Discordo que os países devem ceder parte da soberania & 17,1 \\
\hline & $\begin{array}{l}\text { Concordo em parte que os países devem ceder parte da } \\
\text { soberania }\end{array}$ & 34,4 \\
\hline & Concordo que os países devem ceder parte da soberania & 37,2 \\
\hline
\end{tabular}


conclusão

\begin{tabular}{|c|c|c|}
\hline $\begin{array}{l}\text { Concordo } \\
\text { que as nações } \\
\text { nascem, crescem } \\
\text { e morrem na } \\
\text { História, (...) }\end{array}$ & $\begin{array}{l}\text { Concordo totalmente que os países devem ceder parte da } \\
\text { soberania }\end{array}$ & 7,9 \\
\hline \multirow{5}{*}{$\begin{array}{l}\text { Concordo } \\
\text { totalmente } \\
\text { que as nações } \\
\text { nascem, crescem } \\
\text { e morrem na } \\
\text { História, (...) }\end{array}$} & $\begin{array}{l}\text { Discordo totalmente que os países devem ceder parte da } \\
\text { soberania }\end{array}$ & 11,3 \\
\hline & Discordo que os países devem ceder parte da soberania & 13,3 \\
\hline & $\begin{array}{l}\text { Concordo em parte que os países devem ceder parte da } \\
\text { soberania }\end{array}$ & 24,7 \\
\hline & Concordo que os países devem ceder parte da soberania & 23,3 \\
\hline & $\begin{array}{l}\text { Concordo totalmente que os países devem ceder parte da } \\
\text { soberania }\end{array}$ & 27,3 \\
\hline
\end{tabular}

Fonte: Projeto Jovens e a História no MERCOSUL (2013). Elaboração da autora.

Verificamos que há uma tendência de relação direta entre aceitar a historicidade, o nascimento e a morte das nações, a uma disposição a ceder parte da soberania a organismos internacionais ou, em outros termos, relativizar a nação como foco absoluto da mobilização dos interesses. Uma conclusão provisória, aqui, é que um processo de integração supranacional pode se beneficiar de um ensino que não estabeleça a nação (em oposição ao mundo) como seu único foco narrativo.

\section{CONSIDERAÇÕES}

Um processo de integração é consequência de um elevado grau de comunicação entre os parceiros envolvidos, gerando uma situação nova, tanto na forma pluralista como na forma de amálgama. Este processo é gerado no intergovernamentalismo, a partir de uma gradação que vai desde a negociação dos interesses dos países envolvidos, até versões mais sofisticadas, definindo-o como um regime intergovernamental que objetiva administrar a interdependência econômica, política e militar entre Estados, negociando sempre políticas de coordenação e integração (MARRA, 2008).

Para haver a integração, é necessário um ato consensual adotado pelos países; um critério diferente do tradicional, no que se refere à soberania das 
nações, uma vez que se aceita a constituição de entidades supranacionais, que ditam normas legais que passam a ser seguidas no Direito interno de cada país; a formação de uma federação de países, embora respeitando as individualidades e características nacionais (MARRA, 2008).

Marra (2008), citando Schaposnik, aponta uma série de razões que justificam a integração:

- solucionar obstáculos tarifários e administrativos, "dumping" e subsídios que provocam uma séria deterioração na relação real dos termos de intercâmbio;

- aumentar o nível ocupacional a índices superiores ao crescimento da população ativa e elevar as condições de vida dos setores com rendas mínimas;

- obter uma melhor negociação internacional por meio da exportação de produtos com maior valor agregado;

- produzir tecnologia adequada às necessidades básicas da população e regular uniformemente o mercado de tecnologia;

- melhorar as pautas de distribuição da riqueza;

- coordenar e alcançar um desenvolvimento auto-sustentável;

- criar uma moeda única para intercâmbios regionais;

- inserir-se, em melhores condições, no cenário internacional;

- formular novos esquemas para confeccionar o modelo de desenvolvimento político, econômico, social e cultural, que seja funcional à dimensão dos países;

- melhorar a capacidade de mão de obra para aumentar as rendas e níveis de vida;

- suprimir ou atenuar os antagonismos que dividem os países, pondo fim às lutas que os afetam e desenvolvendo ativa e concretamente a solidariedade (MARRA, 2008, p. 251, grifos do autor)

Esse elevado grau de comunicação entre os parceiros, citados pela autora como componente importante para um processo de integração, pode ser erigido no contexto escolar, desdobrando-se na construção de uma consciência do Ser latino-americano, do identificar-se como latino-americano. Isto porque o próprio Setor Educacional do MERCOSUL (SEM) compreende que as escolas dos Estados signatários são consideradas um espaço onde culturas regionais podem se constituir e atuar no sentido de uma efetiva consciência de integração e da identidade regional. Todavia, 
compreendemos, assim como Gadotti (2007), que tanto o MERCOSUL, como agora a UNASUL, necessitam se tornarem conhecidos nas escolas. Os projetos do MERCOSUL educacional não são acessíveis, nem para a sociedade civil e nem para a escola. Gadotti, já em 2007, apontava para a necessidade de democratizar o MERCOSUL, fazer com que as pessoas o conhecessem e tivessem consciência da necessidade do fortalecimento dos laços de integração, como um modo de dinamizar a economia, a tecnologia e as condições de vida dos Estados signatários. O autor ainda assinalava que, para isto, era importante que se introduzisse, na formação dos professores, o componente MERCOSUL, pois o professor precisa estar convencido da importância da integração regional, para reconhecer a necessidade do desenvolvimento de uma identidade regional e comunitária.

Diante do que foi exposto nas páginas acima, vimos que as tentativas de integração latino-americana aconteceram baseadas em contextos políticos e econômicos favoráveis a elas. Contudo, entre os países latino-americanos, não houve preocupação com a formação de uma identidade latino-americana que respeitasse a diversidade cultural. Neste sentido, pode-se pensar que a constituição e a consolidação das identidades nacionais destes países podem ter sido um fator inibidor da própria integração e da formação da identidade latino-americana, uma vez que as identidades nacionais exprimem fronteiras que marcam o começo e o fim de uma comunidade.

Também vimos que o MERCOSUL, desde a sua constituição, preocupou-se com a Educação, embora esta preocupação não possa ser considerada um fator isolado dos demais processos de integração, que vinham ocorrendo simultaneamente em outros continentes. A Educação passou a ser um dos eixos importantes da transformação das economias e do perfil produtivo das integrações regionais.

Porém, quando se pensa em desdobramentos no contexto da sala de aula, que resultem na construção da identidade latino-americana e da integração regional, as respostas do questionário expõem sinais de que ainda se faz necessário um longo percurso para que seja possível promover tal construção. 
Há que se questionar: o que o MERCOSUL Educacional e atualmente a UNASUL têm feito para que suas propostas cheguem às escolas? Se existe a compreensão de que elas são consideradas um espaço onde culturas regionais podem se constituir e atuar no sentido de uma efetiva consciência de integração regional, são necessários que a história e a cultura dos demais países cheguem até elas; é necessário fazer circular a produção acadêmica entre os países; é necessário colocar, como meta do MERCOSUL e da UNASUL, a formação continuada dos professores para divulgar, entre os Estados-Partes, o que tem sido produzido da historiografia latino-americana, a fim de que, no contexto da sala de aula, seja exposto um ensino da História menos fragmentado e marcado por permanências. Isto porque, da forma como se vêm construindo as várias tentativas de integração, elas não passarão de processos aduaneiros ou acordos comerciais, cujo papel tem sido muito mais de nos diferenciar do que propriamente nos integrar.

\section{REFERÊNCIAS}

BRASIL. MERCOSUL EDUCACIONAL. Protocolo de Intenções. 1991. Disponível em: <http://www.sic.inep.gov.br/en/documents/doc.../203protocolo-de-intencoes $>$. Acesso em: 05/12/2011.

BAGGIO, Kátia Gerab. As interpretacões brasileiras sobre a América Latina: Breves reflexões. II Seminário Bienal O Ensino de História e Geografia no Contexto do MERCOSUL. Disponível em:<http://unesdoc.unesco.org/ images/0012/001231/123129mo.pdf >. Acesso em 12 ago. 2010.

BAROM. Wilian Carlos Cipriani. Integração latino-americana e consciência histórica: a noção de pertencimento latino-americano de jovens brasileiros. Tese. Ponta Grossa: UEPG, 2017. Disponível em: < http://bicen-tede.uepg. br/tde_busca/arquivo.php?codArquivo=1780>. Acesso em: 30 jul. 2017.

CERRI, Luís Fernando. Dados quantitativos na reflexão didática de estudantes e professores de História. Revista História Hoje, vol. 5, no 10, p. $138-158-2016$. 
. Os jovens e a história - Aprofundando análises voltadas à divulgação e utilização do conhecimento. Roteiro Descritivo do Projeto. Chamada MCTI/ CNPq/MEC/CAPES N 18/2012, 2012.

DIAS, Maria de Fátima Sabino. Nacionalismo e Estereótipos: A Imagem sobre a América nos Livros Didáticos de História no Brasil. In: DIAS, Maria de Fátima S. (Org). História da América: ensino, poder e identidade (pp. 49-64). Florianópolis: Letras Contemporânea, 2004.

FINOCCHIO, Silvia. Reflexões para uma proposta de trabalho sobre o ensino da História e da Geografia no marco do MERCOSUL. In: MARFAN, Marilda Almeida (org.). O Ensino de História e Geografia no Contexto do MERCOSUL (pp.12-13). Brasília: MEC/SEF, 1998.

GADOTTI, Moacir. O MERCOSUL educacional e os desafios do século 21. Brasília: MEC/INEP, 2007. Disponível em: <http://portal.inep.gov.br/documents/186968/485287/ O+Mercosul+educacional+e+os+desafios+do+s\%C3\%A9culo+21/b98ee8dbe3bf-4d8c-89ce-02229911a79e?version=1.1 >. Acesso em 12 jul. 2015.

HOBSBAWN, Eric John. Nações e Nacionalismos desde 1780. São Paulo: Paz e Terra, 2008.

KOLING, Paulo José. O Ensino de História da América na Educação Básica: reflexões a partir dos livros didáticos e obras utilizadas em escolas públicas no Oeste do Paraná. Anais Eletrônicos do VIII Encontro Internacional da ANPHLAC. Vitória, 2008. Disponível em: < http://anphlac.fflch.usp.br/ sites/anphlac.fflch.usp.br/files/paulo_koling.pdf >. Acesso em: 12 out. 2015. LEME, Álvaro Augusto Stumpf Paes. A Declaração de Iguaçu (1985): a nova cooperação argentino-brasileira. Dissertação. Porto Alegre: UFRGS, 2006. Disponível em: <https://www.lume.ufrgs.br/bitstream/ handle/10183/8444/000575916.pdf?sequence=1>. Acesso em: 09 out. 2011. MARRA, Teresinha Aparecida Mendes. Integração Latinoamericana e sua inserção no mundo globalizado. Revista Mosaico, v.1, n.2, p.245-260, jul./dez., 2008. 
MOMMA, Adriana Missae. As políticas educacionais brasileiras no contexto do MERCOSUL: perspectivas e desafíos para o processo de integração. Dissertação de Mestrado. Campinas: UNICAMP, 2001.

PETITAT, André. Produção da escola, produção da sociedade: análise sóciohistórica de alguns momentos decisivos da evolução escolar no Ocidente. Porto Alegre: Artes Médicas, 1994.

PRADO, Maria Lígia. A formação das nações latino-americanas. São Paulo: Atual, 1986.

RAIZER, Leandro. NEVES, Clarissa Eckert Baeta. FACHINETTO, Rochele Fellini. Educação para a Integração: rumo ao Mercosul Educacional?. In: XIV Jornada de Jovens Pesquisadores da AUGM. Empreendedorismo, Inovação Tecnológica e Desenvolvimento Regional. Campinas/UNICAMP, 2006.

RÜSEN, Jörn. Razão Histórica. Brasília: Editora UNB, 2001.

SANTIAGO, Léia Adriana Silva. Ensino de História da América no Brasil e na Argentina (1995-2010): um estudo comparativo sobre a ótica da política de integração regional e da identidade latino-americana. Tese. Curitiba: UFPR. 2012. Disponível em: <http://www.ppge.ufpr.br/teses\%20d2012/ d2012_Leia\%20Adriana\%20da\%20Silva\%20Santiago.pdf >. Acesso em: 30 jul. 2017.

SARAIVA, José Flávio Sombra. O Brasil e a integração hemisférica: vertente histórica. Em Aberto - MERCOSUL; v. 15, n.68, out/dez 1995.

SILVA, Vera Lúcia Correa. Da Operação Pan-Americana aos entendimentos de Uruguaiana: as relações Brasil e Argentina (1958 a 1962). (Dissertação). Porto Alegre: UFRGS, 2005. Disponível em: <http://www.lume.ufrgs.br/ handle/10183/5851>. Acesso em: 15 out. 2010.

SILVA, Vitória Regina. Concepções de História e de Ensino em manuais para o Ensino Médio brasileiros, argentinos e mexicanos. Tese. Universidade de São Paulo, São Paulo, 2006. Disponível em: < file:///C:/Users/user/ Downloads/TESE_VITORIA_RODRIGUES_SILVA\%20(1).pdf >. Acesso em: 13 dez. 2014. 
SOUZA, Ivonete da Silva. Estudos Latino-Americanos: a história e construção de uma disciplina escolar. Anais Eletrônicos do VII Encontro Nacional dos Pesquisadores do Ensino de História. Belo Horizonte, 2006. Disponível em: <file://C:/Users/hp-1/Desktop/4801-16328-1-PB.pdf >. Acesso em: 30 jul. 2017.

VIGEVANI, Tullo; RAMANZINI JÚNIOR, Haroldo. Mudanças da inserção brasileira na América Latina. Lua Nova, n.78, São Paulo, 2009. 


\section{AMÉRICA LATINA, IDENTIDADE LATINO-AMERICANA E IDEOLOGIA NEOLIBERAL}

Wilian Carlos Cipriani Barom

Os jovens brasileiros se sentem latino-americanos? Haveria alguma relação entre o modo de produção capitalista, os valores mercantis e a atual identificação dos jovens brasileiros com a América Latina?

Para refletir sobre estas duas questões, problematizamos os processos cognitivos de identificação de 2240 (dois mil, duzentos e quarenta) jovens, de 22 (vinte e duas) cidades brasileiras, que responderam ao questionário do Projeto Jovens e a História entre os anos de 2012 e 2013². Dividimos nossa análise em três partes: a) a integração da região; b) a reivindicação política da identidade regional; e c) a identidade latino-americana dos jovens brasileiros nos dados do Projeto Jovens e a História.

\section{A INTEGRAÇÃO DA REGIÃO}

Atualmente, faz sentido falarmos em identidade latino-americana para os jovens brasileiros? Vejamos o que a análise do contexto político e econômico tem a dizer.

Nas últimas décadas, observamos o mundo se reorganizar socialmente, politicamente e economicamente. Em várias regiões, os países passaram a se unir por meio de acordos intergovernamentais, dando origem a blocos inter-regionais com finalidades sociais e políticas. Atualmente, o Brasil vem participando de acordos que vão da união de países de mesma língua, histórias próximas, fortalecimento das economias regionais, como também estabelece alianças com países distantes, de economias divergentes e outras culturas. Como critério central, podemos apontar a promoção e

\footnotetext{
"Uma versão reduzida desse capítulo foi publicada na revista Práxis Práxis Educativa, v. 13, n. 3 (2018). ${ }^{1}$ Distribuição dos questionários por região e cidade: Região Norte:- Araguaína, TO (53) e Parintins, AM (87). Região Nordeste - Aracaju, SE (116) e Teixeira de Freitas, BA (42). Região Centro-Oeste Cáceres, MT (151), Cuiabá, MT (135), Rondonópolis, MT (163), Dourados, MS (106), Três Lagoas, MS (69), Iporá, GO (61), Brasília, DF (98). Região Sudeste - Itararé, SP (128), São José dos Campos, SP (142), Belo Horizonte, MG (93), Ituiutaba, MG (136), Uberlândia, MG (150). Região Sul - Curitiba, PR (139), Ponta Grossa, PR (133), Curiúva, PR (26), Florianópolis, SC (142), Passo Fundo, RS (95) e Porto Alegre, RS (155).
} 
manutenção do desenvolvimento econômico, por meio de melhor inserção da economia brasileira no capitalismo mundial, seja para aproveitar o fluxo da economia internacional e alavancar as exportações nacionais, seja para fazer frente aos ditames das grandes economias internacionais, em especial a norte-americana, e suas formas coercitivas de domínio e controle dos mercados (BARNABÉ, 2011).

De acordo com o site oficial do governo brasileiro, atualmente o país participa de dezesseis blocos políticos e econômicos² (BRASIL, 2012), o que totaliza uma relação no âmbito político e/ou econômico com aproximadamente noventa países.

Esse fenômeno de interligação das economias, políticas e culturas, via internacionalização do capital, ganha maior entendimento quando atentamos às transformações que ocorreram no setor produtivo das últimas décadas.

Internamente à organização do trabalho e da produção, a passagem do modelo fordista para o modelo japonês de acumulação flexível, também conhecido como pós-fordista, nos países de capitalismo avançado, garantiu maior internacionalização das produções, diante do contexto de expansão do capital, pós-década de 1970 (HARVEY, 2012)ํ․ Segundo a economista Elizabeth Bortolaia Silva (1994), esta passagem ocorreu de forma bastante lenta e gradual, pois os países do ocidente lançaram muitas dúvidas sobre o modelo japonês de produção: se ele seria mesmo original, rompendo de fato com o modelo fordista precedente; se suas técnicas de gestão eram

\footnotetext{
${ }^{2}$ Comunidade dos Países de Língua Portuguesa (CPLP); Agrupamento Brasil-Rússia-Índia-ChinaÁfrica do Sul (BRICS); G-20; G-15; Cúpula Ibero-americana; Aliança de Civilizações; Cúpula América Latina, Caribe e União Europeia (ALC-EU); Fórum de Diálogo Índia-Brasil-África do Sul (IBAS); Cúpula América do Sul - África (ASA); Fórum de Cooperação América Latina - Ásia do Leste (FOCALAL); Cúpula América do Sul-Países Árabes (ASPA); Associação Latino-Americana de Integração (ALADI); Mercado Comum do Sul (MERCOSUL); Cúpula da América Latina e do Caribe sobre Integração e Desenvolvimento (CALC); Comunidade dos Estados Latino-Americanos e Caribenhos (CELAC); União de Nações Sul-Americanas (UNASUL). Ver em: <http://www.brasil.gov.br/governo/2012/07/ confira-os-blocos-politicos-e-economicos-dos-quais-o-pais-participa>. Acesso em: 28 fev. 2017.

${ }^{3}$ David Harvey não reflete diretamente sobre o Brasil e a América Latina, mas sobre as transformações que ocorreram no centro do sistema capitalista, em especial Europa e EUA, e dele decorreram. Duas leituras que trazem esta discussão para o caso latino são: Os impasses do estado capitalista: uma análise sobre a reforma do estado no Brasil, de Lucia Cortes da Costa (2006) e Globalização, dependência e neoliberalismo na América Latina, de Carlos Eduardo Martins (2011).
} 
confiáveis em longo prazo; e se existiam possibilidades reais e limites na transferência deste modelo para os países ocidentais.

De um padrão industrial centrado na produção e no consumo em massa, em série, na divisão do trabalho em todos os níveis da atividade econômica, na extensão da mecanização e no uso de máquinas dedicadas e de trabalho não qualificado ${ }^{4}$ (modelo fordista), as gestões produtivas se reorganizaram pautando-se na ideia da flexibilidade, com estoques reduzidos e pequenas quantidades, na intenção de suprir as demandas colocadas no momento exato (just in time), atendendo a mercados diferenciados, com públicos mais específicos. Este padrão foi uma reorganização consequente da expansão dos mercados, das pluralidades das demandas, que se acentuaram diante do aumento das redes de comunicações das últimas décadas. Neste regime, os produtos somente foram fabricados ou entregues a tempo de serem comercializados ou montados, o que acabou por desterritorializar os grandes sistemas de fábricas, de suas organizações primárias nacionais, em múltiplos segmentos que se espalharam pelo mundo, na busca por mercados cada vez mais promissores, em um processo de acompanhamento rápido das transformações dos padrões de consumo.

Além da proximidade com relação ao consumidor, essa mudança de regime deu nova liberdade aos sistemas produtivos, que buscaram se desapegar dos tradicionais riscos do modelo de produção em massa; no pensamento de Harvey, entendidos como "rigidez do modelo fordista" (HARVEY, 2012, p. 135). Isto porque se referiam aos grandes investimentos necessários, capital fixo de larga escala e de longo prazo em um mesmo local, em um mesmo mercado, dependente de extensas relações trabalhistas, em íntima relação com o Estado e com suas consequentes políticas de assistência social.

No caso da América Latina, para a década de 1980 e 1990, este processo ainda pode, em certa medida, ser considerado inconcluso, pois, em muitas áreas, ocorrem resistências ou coexistências destes modelos. Para o Brasil, por exemplo, Silva (1994) aponta a falta de consenso no debate acadêmico para definir alguma hegemonia de modelo nos períodos da

${ }^{4}$ Definição de modelo fordista (TOLLIDAY; ZEITLIN, 1985, apud SILVA, 1994). 
década de 70 e 80 . Em seu texto Pós-fordismo no Brasil, distinguiu estilos de fordismos que variaram conforme os períodos. Teria havido uma fase populista em período ditatorial, especialmente na década de 1970, em que predominaram as formas paternalistas de relações entre o capital, o trabalho e o Estado. A década seguinte teria sido um período bastante complexo, caracterizado por: a) uma mescla entre tradições e heranças do passado; b) desaceleração industrial pelo recuo do incentivo do Estado; c) ser um período de particular instabilidade das políticas econômicas; d) (coexistindo aos pontos anteriores) avanços no gerenciamento democrático, especialmente na indústria automobilística. A autora considerou esse período como de transição, um processo, portanto, não homogêneo, em que os resultados encontrados em uma indústria não podiam ser generalizados para outros ramos. Assim, diferenciavam-se e se opunham à interpretação de Ruy de Quadros Carvalho e Juberi Schmitz para o mesmo período, os quais apontaram que a introdução da automação flexível teria gerado, contraditoriamente, também o fortalecimento do fordismo, no estilo brasileiro de um fordismo autoritário. Para a autora, que escreveu em 1995, a década de 1990 seria ainda um período em aberto, o qual, porém, ela teria se precipitado em conceituar como de um fordismo nostálgico, que se iniciava marcado pela heterogeneidade estrutural: grande dispersão da distribuição de renda, disparidades regionais fortes, e altos diferenciais de produtividade entre os setores econômicos e dentro deles (SILVA, 1994).

Retornando à década de 1970, externamente ao caso brasileiro, mas em relação com ele, David Harvey (2012) apontou que as mudanças tecnológicas, as fusões e incorporações de empresas, o impacto do petróleo na economia em 1973, o surgimento da concorrência japonesa (com nova concepção de gestão e produção automobilística), e novas necessidades no que se referiam ao consumo ao redor do globo, foram os acontecimentos que marcaram essa mudança gradual rumo à intensificação da internacionalização do capital, através da flexibilização. De acordo com Corsi (2010), essa reestruturação do sistema, que ocorreu na década de 1970, recompôs a rentabilidade do capital ao deslocar/redistribuir setores importantes da indústria, o que abriu novas fronteiras de acumulação, em especial na Ásia. 
Neste processo, foram introduzidas novas tecnologias que buscaram poupar trabalho e diferentes formas de reorganização do processo de trabalho, acompanhadas da desregulamentação dos mercados e da precarização das condições de trabalho,

[...] mudanças que contribuíram para fragmentar a classe trabalhadora e enfraquecer os sindicatos. Observa-se a rápida e acentuada desregulamentação das economias nacionais, caracterizada pela abertura comercial e, sobretudo, financeira. O incremento da concorrência, a reestruturação produtiva e as novas tecnologias têm condicionado profundas alterações nas classes sociais, na luta de classes e na posição dos países no capitalismo globalizado (CORSI, 2010, p. 123).

Um deslocamento espacial que ocorreu para a periferia, sob o comando dos grandes oligopólios, de acordo ainda com Corsi (2010), serviu para manter e reestruturar a hegemonia norte-americana, e também iniciou um processo lento de abertura e inserção de economias nacionais periféricas, que passaram a receber estes setores industriais e relocar seus próprios setores no cenário internacional. Ao longo da década de 1980, inúmeras multinacionais, em um movimento crescente, buscaram, nos países periféricos, incentivos fiscais, custos reduzidos em mão de obra, matérias-primas e mercados consumidores, a exemplo da América Latina, onde encontraram terrenos férteis nas economias nacionais endividadas, em contextos inflacionários, de crises políticas e de superação dos regimes ditatoriais militares.

Esse acontecimento foi possível por ter encontrado, nas economias dependentes nacionais, via políticas neoliberais, um processo interno de desregulamentação dos sistemas bancários e dos mercados financeiros, que refletiu na diminuição dos preços dos transportes nacionais e internacionais e nas articulações com os desenvolvimentos das comunicações e dos processamentos de dados. Isto permitiu que as matrizes dos grupos coordenassem e controlassem seus procedimentos globais de produção, espalhados geograficamente (CORSI, 2010). Vale ressaltar que, com esta possibilidade recente de ampliação das exportações, as multinacionais passaram a influenciar gradativamente os espaços políticos dos Estados, 
de modo a criar legislações internas que facilitem o alinhamento com estes interesses externos.

Na América do Sul, no contexto industrial, essas multinacionais passaram a ocupar grandes setores, exercendo hegemonia em variados ramos de atividades, como a indústria alimentícia, siderúrgica, automobilística, metalúrgica, eletroeletrônica, química, farmacêutica e agroindústria. Contudo, no intuito de os estados atuarem como agentes nesse processo de internalização do capital, as medidas políticas, basicamente orientadas pelo Consenso de Washington, FMI e Banco Mundial, com maior ou menor aceitação pelos países latino-americanos, geraram custos sociais. A adoção dessas medidas pelas políticas neoliberais não significou relação direta com o desenvolvimento dessas economias latinas, nem mesmo uma uniformidade nos desenvolvimentos. Arceo e Bausualdo, citados por Corsi (2011), apontaram que, para além dessa adoção de modo estrito, o desenvolvimento das economias latinas dependia de outras complexas determinações, que incluíam: a divisão internacional do trabalho, as características do centro hegemônico, o ciclo da economia mundial, a estrutura interna de classes, os recursos naturais disponíveis, a situação geopolítica, as condições históricas herdadas e as lutas de classe de cada país. Isso, de certo modo, explica a contradição na proposição, de modo uniforme, aos países latino-americanos, das dez medidas de Washington ${ }^{5}$.

Estas políticas podem ser mais bem explicadas quando retornamos à década de 1970, especialmente na Europa e EUA, e percebemos uma gradual recuperação, com grande apelo ideológico, das discussões sobre as potencialidades do livre mercado e da diminuição da regulação do Estado na economia, em substituição às políticas econômicas até então keynesianas, voltadas para o investimento (COSTA, 2006).

A regulação do Estado passou a ser considerada um entrave ao desenvolvimento da economia, pois, especialmente nos países centrais, houve um processo de diminuição do ritmo do crescimento econômico e um aumento nos déficits públicos. A queda na taxa de retorno dos investimentos levou a um crescimento lento da economia, num

\footnotetext{
${ }^{5}$ São elas: disciplina fiscal, priorização dos gastos públicos, reforma tributária, liberalização financeira, regime cambial, liberalização comercial, investimento direto estrangeiro, privatização, desregulação e propriedade intelectual.
} 
contexto de aumento dos déficits públicos e inflação. Iniciou-se uma ofensiva dos setores mais conservadores das classes capitalistas nos países centrais, colocando a tese da necessidade de reduzir a capacidade de intervenção do Estado na economia. (COSTA, 2006, p. 68).

Neste sentido, para a implementação das políticas neoliberais, o Estado foi sistematicamente acusado de possuir gastos públicos além da arrecadação, o que teria favorecido surtos inflacionários, como resultado das despesas consideradas insuportáveis para a economia, a exemplo do sistema de proteção social, do departamento de saúde e do sistema público de Educação. Estes gastos inibiriam os investimentos e o crescimento econômico. A assistente social e professora Lúcia Cortes Costa (2006) aponta, como exemplos nesta conjuntura de ataques, as ideias monetaristas do economista Milton Friedman, membro da escola de Chicago, que retomou as ideias do economista naturalizado britânico Friedrich Hayek. Friedman denunciava o gigantismo do Estado e a supressão da liberdade dos indivíduos. Esta teria sido a bandeira desse movimento conservador, que recebeu o nome de neoliberal, um processo deflagrado inicialmente na Inglaterra por Margareth Thatcher (1979), nos Estados Unidos por Ronald Reagan (1980), na Alemanha Ocidental por Helmut Josef Michael Khol (1982) e, na Dinamarca, por Poul Holmskov Schlüter (1983) (COSTA, 2006). Esse movimento foi uma retomada dos ideais do liberalismo clássico ${ }^{6}$, passando gradativamente a compor as agendas políticas dos anos de $1980^{7}$. O Estado passou a estar no centro da disputa neoliberal, como local de onde emanam as políticas de defesa e liberdade de ação para o grande capital.

A autora ainda indaga sobre a maneira como estas ideias teriam ganhado espaço, dentro das discussões políticas, nos diferentes países, e fragilizado setores organizados da sociedade. Foi um período em que o discurso conservador ganhou muita força e aceitação, e este fato só foi possível dada a convergência de pelo menos três fatores.

\footnotetext{
${ }^{6}$ A autora assim define estes ideais: “as ideias de que o indivíduo é o responsável pelo seu desenvolvimento, que os salários comprometem os lucros, que a nova base tecnológica exige mudanças no mundo do trabalho e que é preciso dinamizar o mercado, reduzindo o Estado. Neste contexto histórico, a palavra mágica do capital é a competitividade, sua alma é a concorrência e sua ética é o egoísmo individualista, voltado para os interesses privados" (COSTA, 2006, p. 74).

${ }^{7}$ Para Perry Anderson (1995), o movimento neoliberal vem se gestando desde o final da II Guerra Mundial, sendo o seu texto de origem O Caminho da Servidão, de Friedrich Hayek, escrito já em 1944.
} 
Analisando como ganharam força as ideias neoliberais, aceitamos a tese de que a ascensão desta nova direita conservadora está ligada às crises econômicas e políticas do período de 1960 a 1980, ao questionamento do modo de produção fordista e ao modelo de gestão estatal de amplas esferas produtivas, ditas estratégicas (COSTA, 2006, p. 77).

Esse foi um processo de ascensão das ideias neoliberais que, em termos propagandísticos, de acordo com o economista David Ibarra (2011), incidiu sobre a América do Sul como uma tese esperançosa de que a liberdade dos mercados compensaria o atraso histórico das nações, ao se abrirem as fronteiras e estabilizarem-se os preços e as contas públicas. Esperavase que o desenvolvimento exportador e os investimentos estrangeiros erradicassem a pobreza, promovessem o desenvolvimento tecnológico e até mesmo incentivassem a transparência nas ações dos governos, como antídoto à corrupção.

Para os países de capitalismo avançado, especialmente os países da Organização para Cooperação e Desenvolvimento Econômico (OCDE), Perry Anderson, em seu texto Balanço do Neoliberalismo (1995), apontou sucessos e derrotas na implementação que ocorreu na década de 1980. No seu propósito de deter a inflação da década de 1970, o êxito foi inegável, no conjunto de países da OCDE a taxa caiu de $8,8 \%$ para $5,2 \%$; no referido à deflação, condição para a recuperação dos lucros, também houve êxitos reais, o lucro das indústrias subiu de $4,2 \%$ para $4,7 \%$; outros sucessos, inerentes ao propósito neoliberal, foram a contenção dos salários, a derrota do movimento sindical, o aumento no grau de desigualdade social e o aumento na taxa de desemprego, que subiu de $4 \%$ para $8 \%$ no final da década de 1980. Quanto aos insucessos da proposta, o autor aponta dois casos: as taxas de crescimento que não corresponderam às medidas adotadas, já que a desregulamentação financeira criou condições muito mais propícias para a especulação do que para a produção; e o peso do Estado de BemEstar, que não diminuiu muito (tese também apontada pela economista Celia de Andrade Lessa Kerstenetzky ${ }^{8}$ ), em virtude do aumento nos gastos

\footnotetext{
${ }^{8}$ Segundo Kerstenetzky $(2011,2012)$, o Estado de Bem-Estar (Welfare State) é um tipo de intervenção do Estado que interpreta as vulnerabilidades econômicas e sociais dos cidadãos como problemas da sociedade e não do indivíduo. Assim, desemprego, gravidez, pobreza, acidente de trabalho, a
} 
sociais com o desempregado e o aumento demográfico dos aposentados na população (ANDERSON, 1995, p. 14). Ironicamente, o projeto neoliberal europeu e americano sobreviveu à próxima recessão de 1991, apesar dos aumentos significativos no endividamento privado das famílias e nas contas públicas de quase todos os países da OCDE, o que somou um total de 38 milhões de desempregados para o bloco. Este segundo alento do neoliberalismo nos países da Europa, ainda segundo Perry Anderson (1995), pode ser explicado pela vitória do projeto em outras áreas do mundo, ou seja, a queda do comunismo na Europa Oriental e na União Soviética, de 89 a 91.

Para o caso da América Latina, de modo ainda mais pragmático, também como consequências destas políticas, visto que, apesar da inédita experiência chilena de Augusto Pinochet (1973) e da variante neoliberal progressista boliviana de Victor Paz Estenssoro (1985), o neoliberalismo adentra na região basicamente na virada da década de $1990^{9}$. Fernando Jorge Correia de Freitas (2003) assinala o aumento da desigualdade social, o fenômeno da favelização das cidades, o processo gradual de extinção dos direitos trabalhistas e o detrimento dos mercados e indústrias nacionais em favor do consumo e dos investimentos internacionais. Assim, de certa forma, a década de 1980 representou um período transitório de desajuste entre as heranças econômicas, sociais e políticas do período desenvolvimentista, a exemplo do Brasil, e as mudanças em curso no cenário internacional. Ao mesmo tempo em que se intensificavam as desigualdades sociais, econômicas e culturais internas dos países latino-americanos, o que pode justificar a ascensão dos governos de centro-esquerda na década

\footnotetext{
incapacidade de trabalho em decorrência da velhice ou doença, aposentadoria, entre outros, são questões que passam a ser de interesse do Estado nos países da OCDE, basicamente a partir do período entre guerras. O diagnóstico da autora é de que o Welfare State tradicional, centrado na seguridade, encontra-se em um processo de adaptação para responder aos novos riscos sociais. Os avanços das últimas décadas nos direitos civis e sociais e os respectivos aumentos nos gastos públicos, segundo a autora, enquadraria o caso brasileiro como um mix entre os modelos liberal, conservador e social-democrata (dependência dos cidadãos em relação ao mercado, família ou Estado para se assegurarem do Bem-Estar, os três regimes de Welfere State propostos pelo sociólogo dinamarquês Gosta Esping-Andersen em 1990).

${ }^{9}$ Segundo Perry Anderson (1995, p. 19), a virada continental em direção ao neoliberalismo começou basicamente na presidência de Salinas, no México (1988); seguida da chegada ao poder de Menem, na Argentina (1989); da segunda presidência de Carlos Andrés Perez, no mesmo ano, na Venezuela; e da eleição de Fujimori, no Peru (1990). Podemos, ainda, acrescentar o caso brasileiro, com a presidência de Fernando Henrique Cardoso (1995).
} 
de $2000^{10}$, como rechaço popular às políticas neoliberais,, no campo internacional, no âmbito político e econômico, os estados buscaram promover acordos de integração regional como forma de melhor se adequar ao contexto internacional, fazer frente à influência norte-americana e asiática, e também consolidar mercados (regionais e globais) aos interesses das exportações nacionais. Esta é a interpretação do cientista político Israel Roberto Barnabé, em seu texto Unasul: desafios e importância política, que compreende o fenômeno recente da integração latina como uma forma ampliada de regionalismo aberto.

[...] a formação de blocos regionais, o chamado regionalismo, é atualmente uma das principais características do cenário internacional. De relações que anteriormente se davam apenas entre unidades políticas individuais, temos hoje uma gama de acordos que envolvem negociações isoladas entre países, relações intra-blocos, relações entre países individuais e blocos econômicos e relações entre blocos (BARNABÉ, 2011, p. 45).

Ao atribuir maior protagonismo aos atores políticos, no entendimento do regionalismo como uma estratégia de Estado, o autor buscou demonstrar a fragilidade do pensamento dualista (dentro/fora), no entendimento da atual configuração dos Estados Nacionais, ao apontar a coexistência crescente de empresas multinacionais/transnacionais no continente sul-americano com as políticas específicas de Estado que, em uma aparente contradição, buscam defender os produtos e recursos nacionais e regionais. Divergindo um pouco de David Ibarra (2011), que indicou a dissolução dos Estados e entidades nacionais, Barnabé (2011) apontou para um rearranjo de suas funções e responsabilidades, a partir de uma aproximação entre os

\footnotetext{
${ }^{10}$ Destacamos os governos de Hugo Chaves (1999/VEN), Luís Inácio Lula da Silva (2003/BRA), Néstor Carlos Kirchner (2003/ARG), Evo Morales (2006/BOL), Rafael Correa (2007/ECU) e José Alberto Mujica Cordano (2010/URY). Para o caso brasileiro, convém apontar que a reforma democrática do Estado, construída por meio da elaboração da Constituição de 1988 (que sintetizou as bases legais de um Estado com responsabilidades sociais), foi sufocada pela reforma liberal da década de 1990: "uma reforma democrática que nasceu num contexto de contra-reformas liberais" (COSTA, 2006, p. 165). Esta é a interpretação de Lúcia Cortes da Costa, com a qual concordamos, que descreve a década de 1980 como um período de significativo avanço nas forças democráticas do país, que foi logo silenciado pelos governos de Fernando Collor de Mello e depois de Fernando Henrique Cardoso, que governaram de forma antidemocrática e centralizadora, à base de medidas provisórias, o que suprimiu as demandas dos movimentos sociais. Neste sentido é que compreendemos o período posterior do governo de Luis Inácio Lula da Silva, como um período de apropriação do Estado, em significativa medida, por estes setores até então marginalizados pelas políticas sociais e econômicas.
} 
interesses privados e de Estado: um empoderamento da máquina pública em função dos interesses comerciais privados (o estabelecimento de barreiras alfandegárias e não tarifárias, o controle sobre a força de trabalho, sobre o valor dos salários e o uso do mecanismo cambial, a fim de dar competitividade à economia nos mercados interno e externo).

Para além de um movimento crescente de fluxos de capitais e produtos, o fenômeno do regionalismo também incentivou e intensificou as ondas migratórias que já existiam na região, colocando em maior contato os produtos, as pessoas, suas culturas, suas histórias e ideias.

Esta relação se encontra no último informe do Sistema Contínuo de Relatórios sobre Migração Internacional nas Américas (SICREMI), de 2015. Neste relatório, referindo-se ao período de 2010 a 2013 (período de coleta dos dados do projeto Jovens e a História), constatou-se que os fluxos migratórios intrarregionais aumentaram $17 \%$, quase uma dobra em quatro anos (SICREMI, 2015, p. 13). Este crescimento, superior à média das migrações inter-regionais em direção aos países americanos (5\%), está associado con la estabilización o la disminución de movimientos de América Latina y el Caribe a países de la OCDE; por otro lado, también parece estar asociado a la creciente importancia de los procesos de integración regional entre los países de las Américas, en particular el Mercado Común del Sur (MERCOSUR), la Comunidad Andina de Naciones (CAN), la Comunidad Caribeña (CARICOM) y el Sistema de la Integración de Centroamérica (SICA) (SICREMI, 2015, p. 5).

Para o caso brasileiro, neste período, os dados demonstraram o país como o destino preferido dos migrantes bolivianos, paraguaios e uruguaios. Assim como indicou que estes três países também se apresentaram como os principais destinos de migrantes brasileiros na região. $\mathrm{O}$ que nos sugere, além das oportunidades migratórias que decorrem naturalmente do fenômeno do regionalismo, pois o Brasil tem forte relação de exportação e importação com Argentina, Bolívia, Chile, a proximidade geográfica também como um critério importante e decisivo nas opções migratórias das pessoas. 
Outros dados que ainda servem para o debate, dispostos no Sistema Nacional de Cadastro e Registro de Estrangeiros (SINCRE), da Polícia Federal, dizem respeito ao aumento bastante expressivo de estrangeiros no Brasil na última década. No ano de 2003, o índice de estrangeiros (quantidade por mil) era de 25,82, passando para 54,58 no ano de 2010, e 107,621 no ano de $2013^{11}$. Assim, apesar de não podermos discriminar com precisão a quantidade de imigrantes exclusivamente sul-americanos, contidos neste índice, convém apontarmos que o índice quadriplicou. Em outras palavras, nos últimos anos, o brasileiro passou a conviver com maior frequência com imigrantes estrangeiros, uma imagem que possivelmente se tornou mais presente no imaginário social.

Podemos também indicar que, em alguma medida, estas migrações regionais foram favorecidas pelas proximidades linguísticas na região. Quando observamos as línguas oficiais de cada Estado, percebemos certa homogeneidade em torno da língua espanhola. Argentina, Chile, Colômbia, Equador, Paraguai, Peru, Uruguai e Venezuela têm o espanhol como língua oficial, que coexiste atualmente com o quíchua, o aimará e o guarani ${ }^{12}$. A língua portuguesa, que embora só ocorra como oficial no território brasileiro, ganha notoriedade na região por apresentar um número maior de falantes do que a somatória dos falantes de língua espanhola na América do Sul. Contudo, estas duas línguas não se distanciam radicalmente, por compartilharem a mesma origem latina. Compreendendo a língua como um veículo de cultura, podemos perceber que, além de facilitar a mobilidade entre os habitantes da região, estas proximidades linguísticas também permitiram uma história de encontros entre culturas, hibridismos e sincretismos (PARKER GUMUCIO, 2008).

Assim, de modo sintético, podemos afirmar, até aqui que, na a esteira das relações comerciais que atualmente são amplificadas pelo acontecimento do regionalismo político, ondas migratórias vêm ocorrendo, no caso brasileiro, especialmente nas zonas de fronteira, aproximando produtos, pessoas, histórias, culturas e ideias.

\footnotetext{
${ }^{11}$ Disponível em: 〈http://www.pf.gov.br/imprensa/estatistica/estrangeiros >. Acesso em: 02 fev. 2017. ${ }^{12}$ As exceções são as Ilhas Malvinas, Ilhas Geórgia do Sul e Guiana, que apresentam o inglês como língua oficial, a Guiana Francesa que apresenta o francês, e o Suriname o holandês.
} 
É neste contexto de contato, apontando para um futuro de proximidades ainda maiores entre estes povos, que os documentos oficiais que propõem a integração à região vêm reivindicando a necessidade de criação/ valorização/encontro de uma identidade latina comum, supranacional, como forma de auxílio à integração.

\section{A REIVINDICAÇÃO POLÍTICA DA IDENTIDADE REGIONAL}

Em uma perspectiva recente, desde o ano de 1980, com a Associação Latino-Americana de Integração (ALADI), depois com a criação do Mercado Comum do Sul (MERCOSUL), em 1991, e atualmente configurados em torno da União das Nações Sul-Americanas (UNASUL) desde 2008, os países sul-americanos buscam romper as distâncias históricas e aproveitar as proximidades geográficas para iniciar projetos regionais mais sólidos de laços políticos e econômicos. Mesmo divergindo sensivelmente em suas intenções, os três projetos de integração apresentaram importância na construção direta de uma cultura de integração, e na esfera política e econômica, que vêm refletindo nas demais esferas culturais e sociais dos países envolvidos.

Quando adentramos, de modo breve, nos documentos do MERCOSUL e da UNASUL, percebemos maiores detalhes que enriquecem nossa discussão acerca da reivindicação política da identidade regional.

Com o Tratado de Assunção, assinado em 23 de março em 1991, o projeto historicamente idealizado de união comercial entre os países sul-americanos ganhou maior solidez na proposição da criação legal do bloco do MERCOSUL. Com o fim dos governos autoritários no Brasil e na Argentina, iniciou um período de superação dos limites de ordem imaginária e política na região. O período de menor influência dos EUA sobre a região, o aproveitamento dos rios e da energia (Brasil - região platina) e o apoio brasileiro na questão das Malvinas, em 1982, foram passos fundamentais no desarmamento dos espíritos e na aproximação entre os eixos industriais e comerciais de Buenos Aires e São Paulo, o que resultou na instituição do MERCOSUL (SANTIAGO, 2010). 
No tratado de Assunção foi idealizado um acelerado processo de desenvolvimento econômico com justiça social, entre Brasil, Argentina, Uruguai e Paraguai (denominados Estados Partes). Em consonância e respeitando a vigência da Associação Latino Americana de Integração, de 1980, os Estados Partes buscaram aproveitar de modo mais eficaz os recursos disponiveis, melhorar as interconexões físicas e as políticas macroeconômicas e setoriais (de comércio exterior, agrícola, industrial, fiscal, monetário, cambial e de capitais, de serviços, alfandegário, de transportes e comunicações). Assim, eles viriam a reduzir as tarifas alfandegárias na intenção de melhor inserção internacional em meio aos novos espaços econômicos criados no cenário mundial. O MERCOSUL logo se apresentou como uma resposta ao rápido sucesso dos Tigres Asiáticos (Hong Kong, Coreia do Sul, Singapura, Taiwan), ao longo da década de 1980, e às movimentações no continente europeu, em torno da criação da União Europeia, em 1993.

Argumentos como melhorar as condições de vida de seus habitantes, e união mais estreita entre seus povos demonstraram a relação presente no texto do documento, entre sucesso econômico e promoção do desenvolvimento social. A diferença, quando comparamos com o Tratado de Montevidéu 1980, que instituiu a Associação Latino Americana de Integração (ALADI), é que o MERCOSUL avançou, ao se desdobrar em outros documentos que contemplaram a necessidade de incentivar e regulamentar relações de natureza não comerciais. Aqui, destacamos seus desdobramentos na área da cultura e educação, com a criação do Setor Educacional do MERCOSUL (SEM), idealizado a partir do Protocolo de Intenções, ainda em 1991.

Em 13 de dezembro do referido ano, na cidade de Brasília, reuniramse os ministros da Educação de Argentina, Brasil, Paraguai e Uruguai, no estabelecimento de um acordo de natureza especificamente educacional, como complemento ao tratado firmado em Assunção. O Protocolo de Intenções expôs uma dupla natureza. Por um lado, apresentou-se intimamente vinculado aos interesses que buscavam otimizar a produção, em expressões como a melhoria da produção requer a elevação de níveis de educação, e para fortalecer a ampliação das atuais dimensões de seus mercados nacionais é fundamental considerar a Educação, em uma relação estreita entre comércio e 
educação. A educação escolar foi vista como fundamento para que se consolide e desenvolva a integração comercial, especificamente com currículos voltados a temas relacionados ao trabalho, emprego, produção e inovação científico-tecnológica. Por outro lado, o documento também apontou um sentido de integração que julgamos, aqui, ser mais solidário: de superação das históricas distâncias culturais, utilizando expressões aglutinadoras. Seria uma ideia de nós, entendendo a educação como instrumento nesse processo positivo de promoção de uma coletividade comum, em demonstrações como a integração da herança cultural dos povos latino-americanos, a capacidade dos povos latino-americanos de se reencontrarem nos valores comuns e na afirmação de sua identidade ante os desafios do mundo contemporâneo, e formação de uma consciência social favorável ao processo de integração. O que podemos evidenciar é que, embora tenha sido um documento submisso aos interesses do Tratado de Assunção, abriu margem para uma utopia de integração que superasse as distâncias culturais e históricas entre os países e promovesse uma cultura de integração mais solidária, baseada na justiça social, na defesa da democracia, igualdade e liberdade dos povos (TRATADO DE ASSUNÇÃO, 1991).

No âmbito do ensino da História, apresentou possibilidade de construção de uma cultura democrática, de uma "consciência histórica e cidadã", e de uma "identidade latino-americana" a ser viabilizada na Educação Básica dos Estados Partes (SANTIAGO, 2010, p. 15).

O documento apostou na promoção do conhecimento recíproco entre os países, na superação da ideia outro, e no conhecimento de culturas e histórias como forma de construção dessa solidariedade empática, o que remeteu às sugestões, no âmbito da educação, de acréscimos de conteúdos relacionados ao MERCOSUL nos currículos escolares, sugestões de intercâmbios de alunos e professores, acesso público aos idiomas oficiais do MERCOSUL (espanhol e português) e estímulo à circulação de bens culturais e produções conjuntas.

Pesquisadoras da área do ensino da História, como Maria Silvia Cristofóli, Maria de Fátima Sabino Dias e Marise da Silveira Veríssimo viram, no MERCOSUL e MERCOSUL Educacional, a possibilidade de aproximação entre sistemas escolares brasileiros e latino-americanos. 
Ao propor a identificação e reflexão sobre as semelhanças e diferenças culturais, com vistas à estimulação de uma identidade latino-americana, ressemantiza-se a própria noção de integração. Mais do que autoproteção regional, aponta-se na direção da criação de uma consciência crítica, inspirada em uma postura com base em princípios da educação intercultural. Em síntese, uma "consciência cidadã", capaz de identificar as semelhanças, conviver solidariamente com as diferenças e lutar para vencer as desigualdades (CRISTOFÓLI; DIAS; VERÍSSIMO, 2005, p. 28, grifos das autoras).

Neste sentido, foi o Protocolo de Intenções que estabeleceu as bases do Primeiro Plano Trienal a nortear as práticas políticas dos Estados Partes. Foi através desses planos que o Setor Educacional do MERCOSUL construiu, conjuntamente, regulamentações para a esfera educacional. Após esse Primeiro Plano, implementado a partir de 1992 e prorrogado até 1998 , outros cinco documentos foram criados $^{13}$. Quando observamos a totalidade deste outros documentos, percebemos um caminho sólido de planejamento, conquista e maior complexidade no trato das integrações. Isto remete, até o presente momento, a uma história de 25 anos de construção coletiva dessa união, a partir da escolha da Educação como eixo central. Se, inicialmente, o primeiro Plano Trienal apresentou intenções gerais, aspirações e desejos, o Plano Trienal de 2011-2015 sintetizou uma rica estrutura política internacional estabelecida com órgãos, comissões, princípios, objetivos, conquistas, metas e prazos de integração.

A missão do Setor Educacional do MERCOSUL, visivelmente elaborada e reelaborada ao longo dos planos, em sua última versão, pode ser sintetizada no parágrafo abaixo.

Formar um espaço educacional comum, por meio da coordenação de políticas que articulem a educação com o processo de integração do MERCOSUL, estimulando a mobilidade, o intercâmbio e a formação de uma identidade e cidadania regional, com o objetivo de alcançar uma educação de qualidade para todos, com atenção especial aos setores mais vulneráveis, em um processo de desenvolvimento com justiça social e respeito à diversidade cultural dos povos da região (MERCOSUL, 2011, p. 10, grifo nosso).

\footnotetext{
${ }^{13}$ MERCOSUL 2000: desafios e metas para o setor educacional (1996), Plano Trienal do Setor Educacional do MERCOSUL, 1998-2000 (Segundo Plano Trienal), Plano Estratégico 2001-2005 (Terceiro Plano Trienal), Plan del Sector Educativo del Mercosur, 2006-2010 (Quarto Plano Trienal), e Plan del Sector Educativo del Mercosur, 2011-2015 (Quinto Plano Trienal).
} 
Podemos perceber a ideia de criação de um espaço comum, de circulação de alunos e professores, conhecimentos, experiências, políticas públicas e tecnologias que colaborem na promoção do (re)conhecimento mútuo e fortalecimento da igualdade social com respeito à diversidade cultural. A partir desse horizonte, o Plano de 2011 buscou atentar, concomitantemente, a três dimensões - o ensino básico, o ensino tecnológico e o ensino superior -, a partir de cinco objetivos principais:

1. Contribuir para a integração regional acordando e executando políticas educacionais que promovam uma cidadania regional, uma cultura de paz e o respeito à democracia, aos direitos humanos e ao meio ambiente;

2. Promover a educação de qualidade para todos como fator de inclusão social, de desenvolvimento humano e produtivo;

3. Promover a cooperação solidária e o intercâmbio, para a melhoria dos sistemas educacionais;

4. Promover e fortalecer os programas de mobilidade de estudantes, estagiários, docentes, pesquisadores, gestores, diretores e profissionais;

5. Acordar políticas que articulem a educação como um processo de integração do MERCOSUL (MERCOSUL, 2011, p. 13, grifo nosso).

São objetivos amplos, que remeteram a um novo contexto de produção, posterior às reformas políticas na América Latina e às crises econômicas (2001 e 2008), e que inseriram, como pautas, objetivos como paz, direitos humanos, meio ambiente, educação de qualidade, inclusão social e cooperação solidária. Esse último Plano Trienal seria um amadurecimento do tom otimista encontrado no Plano de 2006-2010. Apresenta-se como uma guinada, que desloca a posição da educação da estreita submissão ao mercado para uma compreensão do trabalho como possibilidade de humanização e superação das desigualdades sociais. O ensino tecnológico, como possibilidade de transformação, foi compreendido em conjunto com o ensino básico e o superior. Esta constatação é possível quando consideramos, especificamente, a proeminência da relação educação-mercado presente no Plano trienal de 1998, que contrasta com esta última visão. Mesmo contendo a ideia da necessidade de uma integração cultural, baseada no reconhecimento de valores comuns, o documento expressava, em 
sua primeira parte, o entendimento de que apenas a inserção dos sistemas político-econômicos na economia mundial não garantiria, por si só, o crescimento e o desenvolvimento das economias regionais. Faltaria um elemento aglutinador/potencializador, identificado na integração educacional, como estímulo permanente à integração econômica. Nesta primeira parte do documento de 1998, educação e trabalho estão relacionados de tal forma que parecia ser o objetivo central da educação a potencialização da produção. Em expressões como

[...] os sistemas educacionais serão pressionados para que continuem melhorando a qualidade da educação que oferecem e para que controlem a qualidade do resultado que obtêm, a fim de assegurar a formação de competências (saberes, práticas e atitudes) em níveis equivalentes e facilmente credenciáveis, num espírito de integração regional [...] as mudanças e inovações educacionais deverão acelerar seu ritmo, a fim de satisfazer oportunamente os requerimentos do setor laboral [...] O Setor Educacional do MERCOSUL expressa a certeza de que, no quadro descrito, a educação constitui um elemento fundamental para preparar os cidadãos para o desafio decorrente do aparecimento de novos modos e estilos de produção $(\text { MERCOSUL, 1998) })^{14}$.

Este tom direto, considerando o aluno do processo educativo como um recurso humano da produção, diminuiu significativamente nos documentos posteriores. Sobre esta questão, o último documento até assinalou, como sucesso alcançado, a consolidação recente da "concepção de educação como um direito humano e um bem público e social" (MERCOSUL, 1998), que vem se expandindo nos ordenamentos jurídicos dos países da região.

Deste modo, de acordo com o documento, poderíamos supor que mudanças estariam acontecendo nos sistemas legais dos países, no que tange, direta ou indiretamente, aos sistemas escolares, sendo motivadas pelos planos norteadores do Setor Educacional do MERCOSUL (SEM). Em alguma medida, ao longo destes vinte e cinco anos, o SEM poderia estar influenciando as políticas curriculares nacionais ou, até mesmo, as políticas que regulamentam os intercâmbios e relações internacionais. Contudo,

\footnotetext{
${ }^{14}$ Disponível em: <http://www.sice.oas.org/trade/mrcsrs/decisions/dec1398p.asp >. Acesso em: 09 jan. 2017.
} 
pesquisas recentes não são muito otimistas a este respeito ${ }^{15}$. Segundo Ivor Goodson (2007), esta relação é possível, já que os currículos oficiais, enquanto prescrições, refletem os interesses de seus governos no esforço de enquadrar as memórias como uma estratégia política de consolidação de identidades e representações. Além da forma como se efetivam, estes currículos possuem, também, uma potencialidade simbólica ao influenciar materiais didáticos, práticas de avaliação, e as formas como o poder público define suas relações com as instituições escolares, formando uma cultura que decorre dos currículos (SACRISTÁN, 2013).

Avançando em nossa discussão, em paralelo com os acontecimentos e atividades do MERCOSUL e do Setor Educacional do MERCOSUL, um novo bloco de integração consolidou-se na região. Em 23 de maio de 2008, na cidade de Brasília, contando com a presença de representantes de doze países, foi firmado o Tratado Constitutivo da União das Nações Sul-Americanas (UNASUL) ${ }^{16}$. Um bloco maior do que o MERCOSUL, com o desejo de integrar e unir toda a América do Sul.

Este processo iniciou em 2000, quando foi realizada a primeira Reunião dos Presidentes da América do Sul, e formalizada a Integração da Infraestrutura Regional Sul-Americana (IIRSA). Na III Reunião, em 2004, foi lançada a Comunidade Sul-Americana de Nações (CASA), projeto inicialmente conduzido pelo presidente venezuelano Hugo Chaves, com o objetivo de constituir um bloco econômico amplo para a região (BARNABÉ, 2011). Em 2007, este nome foi alterado para UNASUL, refletindo a ampliação das frentes de atuação do bloco que, para além de aproximar as economias, projetou-se na intenção de integrar políticas e sociedades. Essa demarcação está posta no início do texto de seu Tratado Constitutivo:

APOIADAS na história compartilhada e solidária de nossas nações multiétnicas, plurilíngues e multiculturais, que lutaram pela emancipação e unidade sul-americanas, honrando o pensamento daqueles que forjaram nossa independência e liberdade em favor dessa união e da construção de um futuro comum [...] AFIRMANDO sua determinação de construir uma identidade e cidadania sul-americanas

\footnotetext{
${ }^{15}$ Ver Gonzáles (2010), Conceição e Zamboni (2013) e Santiago et al. (2016).

${ }^{16}$ Argentina, Bolívia, Brasil, Chile, Colômbia, Equador, Guiana, Paraguai, Peru, Suriname, Uruguai e Venezuela.
} 
e desenvolver um espaço regional integrado no âmbito político, econômico, social, cultural, ambiental energético e de infraestrutura, para contribuir para o fortalecimento da unidade da América Latina e Caribe (UNASUR, 2008, p. 5, grifo nosso).

O que identificamos é que, no campo normativo, vem se consolidando um amplo bloco econômico, que busca diminuir as desigualdades internas entre seus membros via aproximação das economias, infraestruturas e recursos naturais, em um processo inicial de flexibilização das fronteiras, incentivando as migrações, o respeito irrestrito aos direitos humanos, o conhecimento mútuo de culturas, saberes e histórias, e a vigilância/defesa das instituições e valores democráticos. No âmbito da política externa, esta integração intenciona dar amplitude ao fluxo de capital, empresas e produtos, consolidando maior presença dos países sul-americanos na política internacional, colaborando, também, com o projeto atual de paz entre as nações: "um mundo livre de armas nucleares" (UNASUL, 2008, p. 5).

Consenso, respeito mútuo, harmonia, diálogo, estabilidade regional identidade e cooperação são palavras que se repetiram ao longo do documento, como princípios que deveriam nortear os futuros temas da agenda internacional e as sugestões de projetos e programas a serem desenvolvidos internamente (regional e nacionalmente). De modo ainda mais explícito que os documentos que foram citados anteriormente, o Tratado Constitutivo da UNASUL colocou em destaque a necessidade da construção de uma identidade e uma cidadania sul-americana, por vezes entendida, também, como identidade sul-americana. Houve uma sutil diminuição, quando comparado aos documentos anteriores, na ênfase da expressão América Latina, que passou a ser substituída, em grande medida, por América do Sul, e o mesmo para a ideia de uma identidade latino-americana e sua substituição por identidade sul-americana. No corpo do texto, esta identidade apareceu de modo dúbio: a) como uma essência, ou um sentimento que já existe, e que todos os indivíduos já possuem (em maior ou menor grau), remetendo a um passado a ser encontrado/relembrado; b) também como um processo, em menor intensidade, um projeto de construção que lança ao futuro, relacionando-se com as decisões políticas a serem desenvolvidas pelo bloco. 
Quando observamos o documento de instituição do Conselho SulAmericano de Educação (CSE) ${ }^{17}$, um dos conselhos ministeriais que compõem a UNASUL, datado de 30 de novembro de 2012 (Cidade de Lima), podemos indicar que não houve nenhuma relação explícita entre educação e mercado de trabalho nos princípios e objetivos do conselho, o que atribuiu certa singularidade ao documento. Dentre estes princípios, destacamos o que se refere às relações culturais entre os estados membros,

Intraculturalidad e interculturalidad: interrelación, diálogo y convivencia entre personas, colectivos, pueblos, identidades, grupos étnicos y nacionalidades, sobre la base de la valoración y el respeto a la diversidad cultural, incorporando sus saberes y conocimientos (UNASUR, CONSEJO DE EDUCACIÓN, 2012, p. 1).

Deste Conselho importa-nos, aqui, a derivação do Plano Quinquenal. Pesquisando acerca das reuniões do Conselho, pelo site do Ministério das Relações Exteriores do Brasil (ITAMARATY), identificamos que a primeira ocorreu em 31 de maio de 2013, quando foi aprovado este Plano Estratégico Quinquenal para a Educação (2013-2017) ${ }^{18}$. Apesar de não ser explícito, podemos inferir que os anteriores assuntos relativos à educação do MERCOSUL Educacional passaram a ser incorporados pela UNASUL, uma vez que, no site oficial do SEM, não houve mais nenhuma indicação de plano trienal após 2011-2015, e no plano quinquenal da UNASUL existem várias referências ao MERCOSUL Educacional e à utilização de seus dados.

Analisando de modo breve este Plano Quinquenal, indicamos que, apesar de ser um plano rico e bastante diversificado, avançou menos do que os Planos trienais do MERCOSUL Educacional, no estreitamento das relações internacionais no âmbito da educação, dado o seu tom inicial e abstrato (em que tudo aparentemente ainda precisa ser iniciado e realizado) e, principalmente, pelo expressivo abandono da ideia de uma integração cultural que implique uma consciência de integração ou, nas palavras utilizadas pelos documentos anteriores, uma identidade latino-americana/ sul-americana.

\footnotetext{
${ }^{17}$ Ver: 〈http://www.unasursg.org >. Acesso em: 03 jan. 2017.

${ }^{18}$ Disponível em: <http://www.itamaraty.gov.br/images/ed_integracao/docs_UNASUL/ RES10.2014ANEXO.pdf >. Acesso em: 03 jan. 2017.
} 
O documento detalhou onze objetivos gerais, com seus respectivos resultados esperados, atividades e metas. Convém, aqui, listarmos estes objetivos na íntegra: promover o acesso e o uso pedagógico das TIC; identificar, sistematizar, difundir e viabilizar a implementação de critérios regionais para a avaliação da qualidade e equidade na Educação; gerar mecanismos que possibilitem a certificação e validação de títulos internacionais; fortalecer as políticas de intraculturalidade, interculturalidade e plurilinguismo nos países da região; promover o desenvolvimento da profissão docente; consolidar políticas de Educação e consciência ambiental; contribuir para a consolidação e afirmação dos cidadãos como sujeitos de direitos e deveres no sistema democrático; promover a universalização da Educação; favorecer a mobilidade entre pesquisadores e estudantes; harmonizar os currículos em torno do ensino das línguas oficiais dos Estados Membros; vincular educação e mercado de trabalho como forma de impulsionar o crescimento e desenvolvimento econômico (objetivo que se apresentou de forma menos explicita do que nos Planos Trienais do SEM).

Enquanto os documentos anteriores insistiam na integração das memórias, das experiências, das histórias, através de uma mudança curricular específica nas áreas de História e Geografia, o Plano Quinquenal de 2013 restringiu a mudança curricular ao componente linguístico, ao estudo das variáveis linguísticas presentes nos países da região. Julgamos isto ser um problema, pois diminuiu a potencialidade da História e do seu ensino em encaminhar propostas que minimizem o isolamento cultural, os desconhecimentos recíprocos na região, e possibilitem projeções de futuros comuns.

Em nenhum momento o documento se utilizou de expressões como identidade, identificação, pertencimento ou consciência, conceitos reiteradamente repetidos nos documentos anteriores. Houve uma explícita opção pelo abandono da busca e valorização do componente cultural comum, seja ele encontrado no passado (documento de instituição da UNASUL), seja no futuro (SEM). O que se apresentou no documento foram caminhos mais pragmáticos de elaboração de espaços na internet, fóruns de debate, eventos de intercâmbio, aplicativos e documentos compilatórios que 
instrumentalizem, de modo prático, a formação docente, e espelhem, de maneira mais democrática, as experiências de êxito dos estados membros. A própria expressão cidadania sul-americana, horizonte que antes se referia a um modo de vida pleno e integrado entre os cidadãos (uma proposta de flexibilização das fronteiras), quando apareceu no atual documento do plano quinquenal, teve o seu potencial reduzido à esfera dos assuntos relacionados apenas à Educação, como sinônimo de democratização de saberes (pela internet e pelo fluxo migratório de pesquisadores).

Neste sentido assumimos, aqui, que este Plano Quinquenal se distanciou significativamente do tom esperançoso do Tratado Constitutivo da UNASUL e dos próprios documentos derivados do MERCOSUL Educacional. Na relação Educação e identidade latino-americana, podemos, então, afirmar que existem duas normalizações da UNASUL, antes e depois de 2013. Contudo, como nossos dados foram coletados neste mesmo ano, convém entendermos que os posicionamentos dos jovens de nossa amostra se inscrevem contextualmente muito mais nos esforços do MERCOSUL Educacional e do tom otimista da criação da UNASUL, do que nos novos rumos do Plano Quinquenal.

Ao sintetizarmos estes dois projetos de integração (MERCOSUL e UNASUL), que apresentaram em suas normativas preocupações com a educação e a identidade, podemos apontar duas conclusões provisórias:

- Identidade como projeto de futuro. Esta concepção foi mais sistematizada nos documentos do Setor Educacional do MERCOSUL. Uma educação de qualidade que, em seus conteúdos, atentasse para as histórias e culturas dos povos da região como pré-requisito na construção de uma cultura de integração, elemento tido como fundamental na manutenção das relações comerciais do bloco. Houve uma articulação entre as categorias educação, identidade, cidadania e trabalho. Esta educação escolar deveria investir no conhecimento do Outro, na intenção de formar uma identidade latina, resultado do conhecimento e reconhecimento das outras culturas e histórias dos povos do bloco. Somente a partir desta identidade, que poderíamos entender como identificação, é que 
haveria uma mudança progressiva e permanente na cultura política dos povos, a se chegar no horizonte promissor de uma cidadania regional, entendida na ideia de livre acesso e conjunto comum de leis e direitos. Para isto, o caminho que deveria ser percorrido é o de combate às desigualdades sociais, na construção de uma região mais equilibrada. Externamente, as relações comerciais deveriam promover melhor ajuste entre as economias nacionais. Internamente, a integração apareceria como possibilidade de trabalho, o que solicitou dos Estados incentivos e políticas públicas no âmbito das formações técnicas em espaços escolares. Há de se destacar que a educação, em sua modalidade técnica, apresentou muito destaque nas normativas trienais do Setor Educacional do MERCOSUL.

- Identidade com maior ênfase no passado (concepção posta no Tratado Constitutivo da UNASUL). A mesma relação entre práticas comerciais e ajuste entre as economias nacionais foi posta no documento da UNASUL. De igual modo, teve tanto a esperança de possibilitar um ajuste entre as desigualdades sociais na região a partir da integração econômica, quanto a necessidade urgente de fortalecer a identidade sul-americana (estas duas relações não aparecem no Plano Quinquenal). A principal diferença na forma como a identidade foi reivindicada pelo tratado da UNASUL diz respeito a maior presença do passado no tom das proposições. A integração foi vista como a concretude de uma história de intenções, ideias e projetos, um tributo ao pensamento daqueles que forjaram as independências e liberdade em favor desta união. Seria a possibilidade da construção da Pátria Grande, aos moldes do que foi idealizado por Simón Bolívar. E a identidade, identificada no presente (em menor grau), precisaria ser fortalecida através dos saberes do passado, conhecimentos e exemplos dos povos da região.

Podemos encontrar esta referência mais constante ao passado, inclusive, em pronunciamentos públicos. O presidente brasileiro Luiz Inácio 
Lula da Silva (2008) afirmou que a UNASUL mexeria com o tabuleiro de poder no mundo, transformando em realidade o sonho integrador dos nossos libertadores (ÚLTIMO SEGUNDO, 2008). Parafraseando o presidente venezuelano Hugo Chaves (2011), com a UNASUL teríamos 18 milhões de quilômetros quadrados, com o maior reservatório de recursos naturais para a vida, seria a utopia de um novo mundo, como diria Simón Bolívar (CORREO DEL ORINOCO, 2011). Já o presidente uruguaio José Alberto Mujica Cordano, na ocasião da posse da presidência anual da UNASUL (2014), também recuperou os ideais libertários do século XIX, afirmando que só conseguiríamos a Pátria Grande com muito compromisso. Poderíamos, ainda, citar as menções do presidente equatoriano Rafael Correa (2009), ou da presidenta argentina Cristina Kirchner (IPROFESSIONAL, 2014), que também fizeram comparações aos processos latinos de independência e aos históricos ideais de integração de toda a América do Sul.

Estes discursos públicos e otimistas se ampararam, em grande medida, na busca por aproximações culturais ou, nas palavras do sociólogo chileno Cristián Parker Gumucio (2008, p. 21), na busca pelo "componente latino", uma cultura que resultaria dos processos históricos de conquista, colonização, independência e experiências democráticas (e ditatoriais) na região sul-americana ${ }^{19}$. Acreditam haver, o que pode ser questionável, “certa homogeneidade cultural" (PARKER GUMUCIO, 2008, p. 21). Esta possível aproximação cultural vem se fazendo em paralelo ao enfrentamento de desafios, como questões regionais de infraestrutura, a construção e a

\footnotetext{
${ }^{19}$ Alguns autores (SADER, 2006; CARDOSO, 2006; CONCEIÇÃO; ZAMBONI, 2013) apontam pelo menos sete elementos compartilhados historicamente, ainda que com variações nacionais significativas. Na história mais antiga, 1) a conquista ibérica; 2) a larga duração de regimes de trabalho coercitivo impostos a amplos contingentes de nativos; e 3) a adoção precoce das instituições políticas e jurídicas do liberalismo após os movimentos de independência. Na história mais recente, 4) o influxo de amplos contingentes de imigrantes europeus, entre o final do século XIX e o início do XX, desencadeando uma nova rodada de integração e miscigenação social e étnica, que resultou em sociedades bastante heterogêneas e com graus de mestiçagem e mobilidade social significativos, quando comparados a outros continentes; 5) a ocorrência de aceleradas migrações do campo para a cidade, especialmente a partir dos anos 1930, e de uma industrialização comandada pelo Estado nacional mediante a utilização de políticas de estímulo e proteção do mercado interno; 6) o aumento das tensões sociais e políticas derivadas da entrada de novas massas urbanas no terreno da competição eleitoral e das reivindicações corporativas e da cidadania, levando à ruptura da ordem democrática e a uma sucessão de regimes autoritários em quase todos os países da região, entre as décadas de 1970 e 1980; 7) o colapso do modelo de desenvolvimento, fruto de seu esgotamento e das transformações produtivas e tecnológicas acarretadas pela globalização e pela onda pró-democracia, que varreu o continente a partir do início dos anos 1980.
} 
manutenção dos corredores bioceânicos ${ }^{20}$, a defesa da biodiversidade e da Amazônia, o abastecimento energético da região, os focos de violência internos e em fronteiras, guerrilhas, narcotráfico, corrupção política interna (PARKER GUMUCIO, 2008, p. 21), além de conflitos bilaterais pendentes, um histórico de guerras (século XIX e recentes ${ }^{21}$ ), problemas de delimitação de fronteiras, a existência do sentimento xenofóbico, a presença de uma memória de desconfiança entre as nações, uma heterogeneidade considerável de posicionamentos políticos e interesses comerciais que continuam a colidir e causar tensões no interior do bloco. Ainda, tendo visto as informações dispostas em nossa primeira parte do texto, um último desafio à integração diz respeito ao papel natural de liderança do Brasil no interior do bloco. Como manter a equidade nas decisões políticas para a região quando um único país é responsável por mais de 50\% do PIB, influencia comercialmente todos os países da região, possui uma extensa área geográfica, com diversidade de recursos naturais, um sólido mercado consumidor interno e ainda é o maior investidor e concentrador dos fluxos de capitais na região? Barrar o imperialismo brasileiro parece ser, também, um desafio à integração. O país não apresenta uma imagem confiável de longa data para os países da América Latina, dadas as experiências e acontecimentos dos séculos XIX e XX. O Brasil desenvolveu-se praticamente de forma autônoma na região. Parafraseando Edmundo O Gorman, em seu clássico A invenção da América, que afirmou que "a América é e, ao mesmo tempo, não é Europa" (O GORMAN, 1958, p. 94), também poderíamos apontar que o "Brasil é e, ao mesmo tempo, não é América Latina"22.

De uma história de denegação, desconhecimentos com relação à América Latina e um desenvolvimento à margem e de costas para o continente, o Brasil vem reivindicando, politicamente e culturalmente, nos

\footnotetext{
${ }^{20}$ No início de 2017, a proposta de construção do corredor Bioceânico avançou na região, dadas as iniciativas do presidente boliviano Evo Morales e do presidente paraguaio Horacio Cartes. Disponível em: <http://www.telesurtv.net/news/Bolivia-y-Paraguay-concretan-proyecto-de-trenbioceanico-20170102-0016.html>. Acesso em: 02 jan. 2017.

${ }^{21}$ Guerra do Paraguai (1864-1870), Guerra do Pacífico (1879-1883), Guerra do Chaco (1932-1935), Guerra Peru-Equador (1941-1942; 1980; 1995), Conflito de Beagle (1978). Além dos conflitos e atritos recentes entre Venezuela e Colômbia, Colômbia e Equador, Argentina e Uruguai, Guiana e Venezuela, Brasil e Paraguai.

${ }^{22}$ Essa paráfrase se encontra no texto O Brasil e a distante América do Sul, de Maria Lígia Coelho Prado (2001, p. 128).
} 
documentos citados, a integração regional, a identidade latino-americana e uma cidadania sul-americana aos povos da região. Curiosamente, o momento histórico do capitalismo atual, o papel do Brasil na economia regional e a tendência do regionalismo como estratégia política da economia internacional propiciaram, ao Brasil, a (contraditória) posição de destaque regional como locus de enunciação deste discurso integracionista. Isso sugere certo componente ideológico na reivindicação política da identidade: uma solicitação de identidade que se fez em meio a relações de poder, interesses político-econômicos, e desejos por aproximações e reconhecimentos culturais em um momento de avanço das políticas multiculturais.

\section{A IDENTIDADE LATINO-AMERICANA DOS JOVENS BRASILEIROS NOS DADOS DO PROJETO JOVENS E A HISTÓRIA}

Escolhemos, aqui, realizar a nossa análise a partir de um olhar sobre o todo, sobre as seis questões escolhidas, na intenção de criarmos um perfil instrumental acerca da questão do pertencimento latino-americano do jovem brasileiro. Isto permitirá criar um arquétipo que poderá ser refletido como modelo e, posteriormente, questionado em pesquisas futuras.

$\mathrm{Na}$ imagem a seguir, listamos as principais alternativas das questões 17, 18, 25, 36 e 40 do projeto Jovens e a História. Estão organizadas a partir de suas respectivas médias gerais, resultantes da totalidade da amostra brasileira (2240 jovens). 


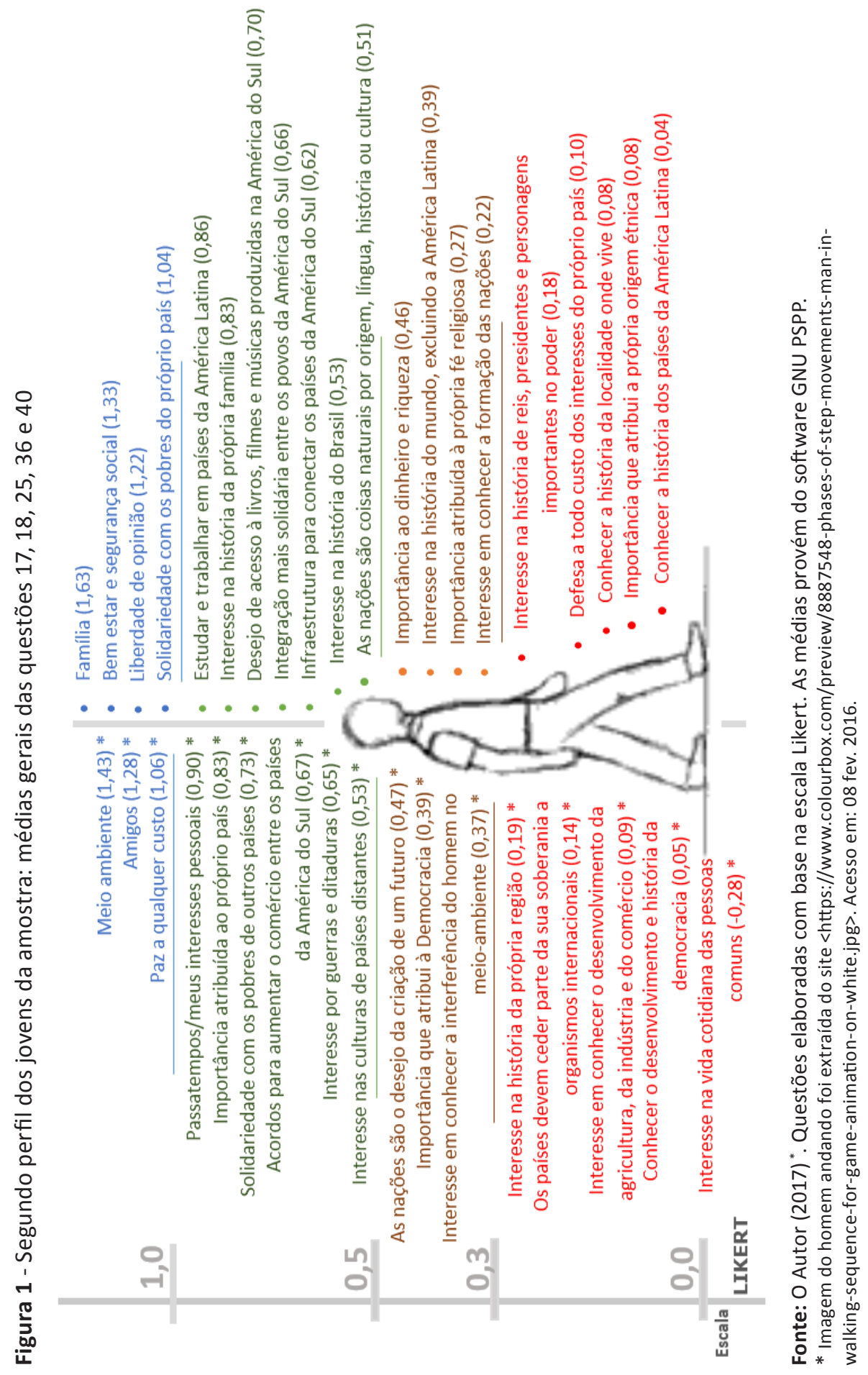


A partir destas médias, convém apontarmos que o sentimento de pertencimento manifestou-se de maneira mais complexa do que a rápida constatação de presença ou ausência. Os dados não apontaram para uma essência latina, desejo que ainda permanece em muitos dos estudos recentes que versam sobre o assunto, demonstrando se tratar mais de uma comunidade imaginária, de modo aproximado a Benedict Anderson (2008), implicando relações políticas e de poder, do que, por exemplo, a rigidez cultural de Samuel Huntington (1997), em sua divisão sólida das civilizações. Assim, os dados indicaram que não convém refletir sobre o pertencimento dos jovens de nossa amostra como vinculado a uma área cultural (localização geográfica que articula, de maneira sólida, cultura e identidade, com limites e fronteiras rígidas ${ }^{23}$ ), mas como resultado de um conjunto de ideias, configurando uma coletividade imaginada (que organiza memórias, mas não está livre de contradições).

Podemos interpretar os dados da imagem acima como a presença de certo patriotismo que precedeu, em alguns pontos; e coexistiu, em outros, com o entendimento e a aceitação dos jovens com relação aos processos de integração na região. Aparentemente, uma significativa importância foi atribuída ao próprio país e, ao mesmo tempo, houve uma pequena recusa e uma neutralidade considerável a modelos de integração que signifiquem a diminuição da soberania nacional (ONU e MERCOSUL). O índice de jovens que discordaram da ideia de perder parte da soberania (discordo totalmente + discordo) foi de $24,4 \%$ (556 jovens), contra o índice de 34,5\% (787 jovens) dos que indicaram concordar com a proposta (concordo + concordo totalmente). Os jovens que assinalaram posicionamento de neutralidade, concordando em partes, somaram 41,1\% (939 jovens).

Tem-se, podemos inferir a partir da aproximação dos dados, uma manifestação possível de um desejo de que o país seja protegido nacionalmente, de tal forma que as garantias sociais e individuais (paz, liberdade e bem estar) não sejam ameaçadas por organismos internacionais. Talvez os jovens estejam relacionando a imagem do estrangeiro a alguma ideia de perigo e ameaça política à autonomia do Estado brasileiro.

\footnotetext{
${ }^{23}$ Referimo-nos à divisão das civilizações de Huntington (1997): civilização sínica, nipônica, hindu, budista, islâmica, ocidental, latino-americana, ortodoxa e subsaariana.
} 
Contudo, este sentimento nacionalista pode ser, aqui, bastante relativizado, pois ele não se traduziu substancialmente no interesse dos jovens pela história do país $(0,10)$, do desenvolvimento das nações $(0,22)$, da democracia $(0,05)^{24}$, no conhecimento da própria região $(0,19)$, da localidade onde vive $(0,08)$ e da história das pessoas comuns $(-0,28)$. Inclusive, os jovens indicaram não ser de grande importância a "defesa a todo custo" dos interesses do país, o que os afasta sensivelmente de um nacionalismo exacerbado. Podemos indicar, possivelmente, ser este um patriotismo com um baixo adensamento de conteúdos e experiências sobre as histórias locais e regionais.

De modo geral, os jovens apresentaram baixo interesse no conhecimento da história dos países da América Latina $(0,04)$ e da sua própria origem étnica $(0,08)$, elementos fundamentais que compõem o sentimento de pertencimento latino-americano, como pudemos observar, segundo os discursos integracionistas do MERCOSUL Educacional e UNASUL. Atribuíram maior importância ao estudo da História do Brasil $(0,53)$, depois, da História do mundo $(0,39)$, da história da própria região $(0,19)$ (esta alternativa não deixou claro aos jovens o conceito de região, deixando ao cargo de suas interpretações pessoais), da localidade onde vivem $(0,08)$ e, por último, da história de países da América Latina $(0,04)$.

Contudo, este desinteresse pela América Latina não pode, aqui, ser generalizado, pois, quando observamos os dados de frequência, percebemos a existência do interesse, da ordem aproximada de $30 \%$ em nossa amostra: de 2352 jovens que responderam a questão, 30,5\% (720 jovens) assinalaram nenhum ou pouco interesse; na zona intermediária, que se configurou como médio interesse, tivemos um total de 35,4\% (835 jovens); e no que disse respeito à somatória de grande e total interesse, tivemos o índice de $34,2 \%$ (807 jovens). Assim, tivemos índices substanciais e semelhantes de

\footnotetext{
${ }^{24}$ É digno de nota que estes dados foram coletados no Brasil em um período muito próximo ao início das manifestações de 2013 (poucos meses antes) que, dentre as diversas bandeiras e reivindicações apresentadas, trouxeram elementos de um patriotismo ufanista e a reivindicação pelo retorno dos militares ao poder. Em certa medida, a baixa média apresentada pela alternativa referente ao desenvolvimento da democracia pode ser considerada como parte deste fenômeno maior, ou como indícios dele. Vale a pena considerar, também, que as manifestações tiveram, contraditoriamente, componentes à esquerda do governo federal, o que ainda pode indicar, pelo outro lado do espectro, uma situação de insatisfação com o atual modelo de democracia.
} 
desinteresse, neutralidade e interesse, o que resultou em uma média geral aparentemente baixa ${ }^{25}$. Contudo, quando somamos os que efetivamente assinalaram desinteresse, mais os que demonstraram neutralidade, tivemos um índice aproximado de $66 \%$ dos jovens.

Esta neutralidade e desinteresse que, em alguma medida tem a ver com o baixo conhecimento dos jovens sobre a região, pode ser reflexo das opções nacionalistas dos currículos escolares,

resulta de especial interés señalar aquí la supuesta falta de comprensión de los estudiantes sobre la historia de otros países de América latina. Nuevamente, tal valoración parece dar cuenta de los límites curriculares $y$ de los puntos ciegos de la formación y prácticas docentes que de un problema de comprensión de los alumnos. En efecto, una indagación sobre las representaciones de un conjunto de capacitadores docentes sobre el proceso de integración regional y sus consecuencias para la enseñanza de la Historia y la Geografía (Denkberg \& Fernandez Caso, 2004) señaló que el Estado nacional y la nación seguían siendo las referencias centrales de los diseños curriculares y las prácticas docentes (GONZÁLES, 2010, p. 09).

Especificamente sobre o caso brasileiro, podemos aproximar os nossos dados à pesquisa recente do professor Gerson Luiz Buczenko (2014), apresentada no texto Ensino de História da América e identidade histórica que, ao refletir sobre a presença da história dos países latino-americanos em manuais didáticos, concluiu pela carência de exposições críticas sobre os contextos sociopolíticos, econômicos e culturais, o que geraria déficits identitários nos estudantes. Em sua análise, identificou que a história da América costuma se apresentar nos manuais didáticos "sem uma contextualização sobre possíveis laços identitários entre os países que compõem o continente americano" (BUCZENKO, 2014, p. 1). Esta é uma análise que indica, particularmente, a possibilidade de os manuais didáticos distorcerem os esforços e aspirações do MERCOSUL Educacional e UNASUL (ou não estarem alinhados às normativas regionais).

Ainda a este respeito, a professora Circe Bittencourt (2005), em seu texto Ensino de história da América: reflexões sobre problemas de identidades, também analisando a presença da História da América em manuais, apontou

\footnotetext{
${ }^{25}$ Assim, a maioria das alternativas que analisamos refletiu esta tensão entre ser uma média neutra homogênea ou uma média com aparência homogênea de neutralidade.
} 
para a história integrada como um esforço recente de superação destes déficits. Sem as tradicionais divisões História Geral, História do Brasil e História da América, buscam constituir um tempo sincrônico que identifique as relações históricas de sociedades situadas em espaços diversos. Contudo, essa perspectiva também coloca novos problemas para o ensino da História, notadamente no que se refere à definição de conteúdos que favoreçam a construção de um sentimento de pertencimento do Brasil à América Latina (BITTENCOURT, 2005, p. 11).

Uma última pesquisa que aqui merece menção é a tese de doutorado Identidade(s) latino-americana no ensino de história: um estudo em escolas de ensino médio de Belo Horizonte, MG, Brasil, de Thamar Kalil de Campos Alves (2011). Segundo a autora, que realizou uma vasta análise em manuais didáticos, currículos oficiais, práticas de ensino e narrativas de alunos e professores, os alunos demostraram, em ambiente escolar, alguns conhecimentos e muito interesse em aprender mais sobre a história da América Latina, repousando o problema não nos manuais didáticos, como indicado anteriormente, mas na distância que possivelmente existe entre os planos de ensino, as práticas docentes e as bases e diretrizes legais.

Assim, entendendo a formação escolar como parte constituinte e como reflexo da cultura, convém compreendermos que estes dados do projeto indicaram, ao mesmo tempo, um substrato de informações e memórias locais que se mesclaram com as lembranças e saberes oriundos dos processos de formação escolar institucional. Ou, de modo ainda mais complexo, segundo o antropólogo Joël Candau (2012), estes posicionamentos podem resultar das memórias que são compartilhadas em uma mesma sociedade (incluindo também o currículo escolar, no mesmo sentido do conceito enquadramento da memória de Michael Pollak).

A partir dessa aprendizagem - adaptação do presente ao futuro organizada a partir de uma reiteração do passado -, esse homem [os jovens de nossa amostra] vai construir sua identidade, em particular em sua dimensão protomemorial. Em um mesmo grupo, essa transmissão repetida várias vezes em direção a um grande número de indivíduos estará no princípio da reprodução de uma dada sociedade. No entanto, essa transmissão jamais será pura ou uma "autêntica" transfusão memorial, ela "não é assimilada como 
um legado de significados nem como a conservação de uma herança”, pois, para ser útil às estratégias identitárias, ela deve atuar no complexo jogo da reprodução e da invenção, da restituição e da reconstrução, da fidelidade e da traição, da lembrança e do esquecimento (CANDAU, 2012, p. 106).

Sobre a valorização da origem étnica, elemento fundamental na composição da identidade latina, tal como postulam os documentos oficiais, a média geral de nossos dados foi significativamente baixa $(0,08)$. Demonstra, aparentemente, não ser uma preocupação dos jovens de nossa amostra atribuir importância à etnia, reconhecer-se como pertencentes a uma coletividade específica de costumes, tradições e histórias. Isto se evidenciou quando comparamos esta às demais alternativas da questão, que apresentaram médias muito mais altas e expressivas. É possível que os jovens tenham se identificado pouco ou não tenham se identificado com as etnias propostas no texto da alternativa (africana, europeia e indígena). Analisando os dados de frequência desta média geral, percebemos que as respostas não foram homogêneas em torno da neutralidade, mas que a neutralidade (média próxima de zero), assim como indicado anteriormente, também resultou do equilíbrio entre significativa parcela de jovens que assinalou alta importância, e outra significativa parcela que assinalou baixa importância, além daqueles que efetivamente assinalaram neutralidade. Do total de 2313 jovens, 733 (31,7\%) assinalaram baixa importância (muito pouca + pouca) à origem étnica, 708 (30,6\%) assinalaram média importância e 872 (37,7\%) assinalaram alta importância (grande + muito grande).

Ainda, acrescentando, indicamos que a média de interesse pela origem étnica diminui gradativamente da fronteira $(0,19)$ em direção à região central $(0,14)$ e litoral $(-0,12)$ do Brasil. Desta última região, Florianópolis e Porto Alegre manifestaram os menores índices da amostra geral, respectivamente, -0,29 e -0,31. Dentre as vinte e duas cidades analisadas, a maior média para esta alternativa foi a da cidade de Brasília/DF $(0,44)$. Esta questão também apresentou maior atribuição de importância nas escolas públicas de periferia $(0,13)$ do que nas privadas laicas empresariais $(-0,14)$. Este foi um dado um tanto curioso, uma vez que, aparentemente, é mais comum a classe média manter seus vínculos com a tradição imigratória europeia e 
ter o conhecimento de suas genealogias. Por fim, o tipo de cidade também, aparentemente, parece ser um critério a ser considerado com relação à valorização da origem étnica, variou inversamente conforme o tamanho da cidade (divisão proposta pelo IBGE): metrópoles $(-0,01)$, capitais regionais $(-0,01)$, centros sub-regionais $(0,20)$, centros de zona $(0,20)$ e centros locais $(0,38)$. Deste modo, de acordo com os dados de nossa amostra, podemos sugerir que a importância que os jovens atribuíram às etnias propostas diminuiu conforme aumentou o tamanho da cidade, o que denota a hipótese de que as tradições (elementos histórico/culturais, costumes, ritos, simbologias) estariam mais diluídas e sincréticas nestes locais.

Ora, com baixo interesse na história da própria região, também com baixo interesse no conhecimento da história dos países que compõem a América Latina e, ainda, com baixa atribuição de importância à origem étnica, como se fundamentaria um discurso integracionista nos dias atuais, a partir dos dados de nossa amostra? Sob que base ele vem se assentando no imaginário popular?

Nossa hipótese é a de que, na ausência de conhecimentos históricos ou memórias que possam ser compartilhadas, as decisões e identificações dos jovens estariam sofrendo interferência dos critérios locais/nacionais de moralidade, que são perpassados, em grande medida, por uma ideologia neoliberal.

Exemplos empíricos desta relação entre ações, conhecimento histórico e moralidade podem ser encontrados na tese O peso do passado: Currículos e narrativas no ensino de história das Ditaduras de Segurança Nacional em São Paulo e Buenos Aires, e no texto Entre muitos 'outros': ensino de história e integração latino-americana, da pesquisadora Dra. Juliana Pirola da Conceição, ambos publicados em 2015 (CONCEIÇÃO, 2015a; 2015b). No mesmo ano de nossa coleta de dados, a pesquisadora buscou investigar a convivência de alunos brasileiros com bolivianos em duas escolas públicas da região central de São Paulo. Uma das questões levantadas pela pesquisadora disse respeito à solidariedade com imigrantes latinos em território nacional, em situação de irregularidade (fugitivos). Como conclusão, a autora percebeu que os jovens que utilizaram a história como referência em seus argumentos 
apresentaram maior grau de solidariedade. Onde a história não estava presente, imperaram os critérios nacionais/locais de moralidade (segundo a autora, em alguns casos, em uma moral individualista, com indícios de nacionalismos extremados, aversão aos estrangeiros, completa indiferença, mobilizando tendências a denúncia e desejo de prisão dos fugitivos).

Em nosso caso, como percebemos significativa prevalência de atribuições de importância às alternativas que se relacionaram à liberdade individual e ao sucesso econômico dos jovens, julgamos que as decisões políticas tenham sido orientadas, em um efeito reflexo do momento já consolidado do neoliberalismo na região, por um conjunto de ideias mercantis que circulam atualmente na sociedade, o neoliberalismo como um modus operandi da consciência. Privacidade, individualismo, liberdade e sucesso econômico formaram um filtro conjunto de visão e de interpretação da realidade, com o qual os jovens possivelmente avaliaram as alternativas do questionário.

Em entrevista ao canal Jornalistas Livres ${ }^{26}$, a filósofa e professora Marilena Chauí realizou uma discussão sobre como as políticas neoliberais refletem nos indivíduos como ideologia neoliberal, que aqui vale recuperarmos. Para a autora, esta ideologia se apresenta como uma estratégia de convencimento que emana das práticas neoliberais (em especial, a transformação dos direitos sociais em serviços/mercadorias). Deste modo cria-se, na sociedade, a ideia de que a privatização dos serviços e direitos sociais é algo bom. Esta construção, que se encontra em um momento avançado em nossa sociedade, remodela a ideia que o indivíduo tem de si próprio, de tal forma que ele não se vê mais como pertencente a uma classe social (como trabalhador), mas através de uma imagem idealizada de empresário de si próprio, que presta serviços e negocia em condições de igualdade com o empregador. Faz parte desta ideologia a ideia de que o indivíduo arque com o ônus de saúde, previdência, educação e formação individual para que se torne mais atraente no mercado, ideia que se alinha a um individualismo extremado, o qual desobriga o Estado de suas responsabilidades a partir da ilusão da meritocracia: o indivíduo constrói a si, investe em si mesmo,

${ }^{26}$ Disponível em: 〈http://migre.me/w07p9>. Acesso em: 05 fev. 2017. 
perde a referência de classe ao se projetar em uma ilusão de consumo e se relaciona socialmente a partir de uma lógica individualista competitiva.

Esta ligação entre ideologia liberal e os posicionamentos dos jovens mostrou-se visível nas avaliações de alternativas como família $(1,63)$, liberdade de opinião $(1,22)$, estudar e trabalhar fora do país $(0,86)$, interesses pessoais, acordos comerciais $(0,67)$, infraestrutura para o comércio $(0,62)$ e desejo de acesso aos produtos da região $(0,70)$. Os jovens de nossa amostra (incluindo os de escolas públicas de periferia) avaliaram as questões relativas ao comércio internacional com a mesma atribuição de importância (ou de modo similar) que a de assuntos relativos aos seus espaços privados/ individuais. Assim, atrelada à ideia de abertura dos mercados e comércio internacional, está uma possível crença de que o sucesso econômico do país geraria, como consequência necessária, a melhoria social para todos, através da distribuição dos produtos e das ofertas formativas (formação pessoal e para o mercado de trabalho), crença que costuma caminhar junto com a defesa da privacidade e da liberdade individual.

Podemos compreender melhor esta relação, de modo breve, a partir da articulação de dois outros conceitos: imaginário e modo de vinculação.

Por imaginário, que em muito se assemelha e enriquece o entendimento do conceito rüseniano de cultura histórica, Juremir Machado da Silva (2006, p. 11) entende:

O imaginário é um reservatório/motor. Reservatório, agrega imagens, sentimentos, lembranças, experiências, visões do real que realizam o imaginado, leituras da vida e, através de um mecanismo individual/grupal, sedimenta um modo de ver, de ser, de agir, de sentir e aspirar ao estar no mundo. ...Motor, o imaginário é um sonho que realiza a realidade, uma força que impulsiona indivíduos e grupos. Funciona como catalisador, estimulador e estruturador dos limites da prática.

O imaginário seria um locus de produção de sentido, um reservatório de uma dada cultura (ou poderíamos falar em reservatórios interligados de culturas), por meio do qual cada grupo interpreta os valores imaginados a partir de sua experiência coletiva, de suas normas e de seus mitos e, ao 
fazê-lo, colabora para a transformação dos sentidos que são comuns a todos os outros grupos (CAZELOTO, 2013).

Esta ideia de armazenamento cultural, comunicável de modo imediato (relações comunicacionais interpessoais) e mediado (indiretamente via aparatos comunicacionais), podemos somar à noção de modo de vinculação, de Edilson Cazeloto (2013), que busca refletir sobre a existência de um imaginário capitalista. Para o autor, o conceito de vinculação busca dar conta da variedade de formas históricas e formas socialmente determinadas com que os vínculos entre seres humanos são construídos em sua dimensão material, de forma a produzir e reproduzir imaginários. Assim, este apontamento de Cazeloto (2013) enriquece a discussão, ao indicar a existência de um processo de vinculação entre o modo de produção capitalista e a universalização de valores mercantis, no âmbito da cultura cotidiana.

É essa perspectiva que sustenta a hipótese de que um processo de longo prazo como a abstração dos vínculos deve corresponder a um conjunto de "necessidades sociais supervenientes". No sistema capitalista, dada a propriedade privada dos meios de comunicação e a íntima relação entre a comunicação e o mercado, essas necessidades confundem-se com a própria reprodução ampliada das relações capitalistas. É nessas relações que deve ser construída a compreensão sobre a questão dos vínculos e do Imaginário(CAZELOTO, 2013, p. 49 , grifos do autor).

Esta possível relação entre imaginário e valores mercantis é o que identificamos nas atribuições de valores dos jovens de nossa amostra. Houve uma supervalorização de temas relacionados ao discurso midiático de apelo e defesa dos interesses, tanto do mercado (interesses comerciais) quanto individuais, o que permitiu considerar isto como uma maneira/ sentido de operação da consciência: o discurso ideológico liberal configura-se como filtro e quadro interpretativo da realidade, e participa das tomadas de decisões.

Assim, possivelmente, como uma forma de autopromoção, por mais que os jovens tenham se sentido ameaçados no contato com os organismos internacionais (ONU e MERCOSUL), atribuíram importância significativa aos assuntos que se relacionaram ao estreitamento dos laços culturais/ comerciais do Brasil com os países da América Latina; ao aumento do 
comércio; aos programas de estudo e trabalho; à construção de estradas e ferrovias; à integração solidária entre os povos da região, e ao maior acesso a livros, filmes, músicas e produtos em geral. Agora, em que medida estes interesses manifestados refletiriam na possibilidade da derrubada ou flexibilização das fronteiras nacionais, tal como propôs a UNASUL, ou estes interesses se alinhariam no sentido da proposição de uma unificação política para a América Latina?

A questão 41 do questionário e sua alternativa "ações para que, no futuro, a América Latina seja um único país" auxilia nesta resposta. Os dados sugeriram apenas $16,4 \%$ de aceitação (371 jovens), um índice de $36,4 \%$ de indecisão, e o maior índice de recusa dentre as questões analisadas, 44\% (1065 jovens). Além da maior recusa, esta alternativa também apresentou o menor índice de aceitação para a questão. Assim, dentre todos os temas da questão (controle sobre o trânsito de veículos; intervenção do governo na economia; igualdade entre homens e mulheres; distribuição de terras para os mais pobres; integração econômica e de moeda na América do Sul; e preservação do meio ambiente em detrimento da economia), quando questionados sobre a unificação política/fronteiriça da América do Sul, os jovens enfatizaram um posicionamento em sentido contrário. Aproximadamente metade dos jovens de nossa amostra foram totalmente contrários à unificação, os quais, somados ao índice de indecisos para a mesma alternativa, totalizou $80,4 \%$.

Talvez esta expressiva recusa tenha relação com os resultados encontrados pelas pesquisadoras Juliana Pirola da Conceição e Maria de Fátima Sabino Dias, as quais, ao investigarem as narrativas de 67 jovens, para o mesmo período, perceberam que eles articularam as ideias de subdesenvolvimento, baixa tecnologia, desigualdade, desmatamento, poluição e violência, de modo bastante vitimista, imobilizador de ações no presente, para representar os países da América Latina (CONCEIÇÃO; DIAS, 2011). Ainda em outro texto, em parceria com a pesquisadora Raquel Alvarenga Sena Venera, Juliana Pirola da Conceição sugeriu que

[...] diante da ausência de repertório sobre o passado, os jovens apreendem com a mídia as representações sobre a América Latina, recortadas apenas em problemas e se identificam com aquilo que 
imaginam ser os EUA. Os problemas contemporâneos da América Latina aparecem bastante nas narrativas dos jovens das duas escolas, entre eles, os que mais se destacaram foram tensões relacionadas ao Gasoduto, As FARC e o narcotráfico e Hugo Chaves na Venezuela como ameaça. Especialmente nas narrativas do DJ existe claramente uma memória pejorativa sendo construída (VENERA; CONCEIÇÃO, 2012, p. 148).

Convém citarmos, aqui, outro trecho que ainda colabora em nossa análise,

[...] apenas uma narrativa questionou o sentido de inferioridade que se constrói sobre o "ser latino-americano": "Hoje em dia, você diz que é americano e as pessoas não reconhecem. Americano é o estadunidense, o brasileiro não é americano, é latino." (Narrativa DJ A05) O jovem diz não existir a possibilidade de ser reconhecido como americano porque essa nomenclatura é legitimada para o estadunidense, no entanto, resta ao brasileiro ser latino. Apesar de ser uma crítica, ela vem afirmando a inferioridade dessa identidade, como se fosse uma sina. O lugar que se deseja como identificação não possui reconhecimentos pelos outros no jogo de identidade e alteridade. Se ele disser que é "americano" não será reconhecido no lugar que gostaria, mas será interpretado como um erro de linguagem. A identidade precisa do reconhecimento dos outros, ela não se processa apenas na identificação dos sujeitos, mas, essa identificação precisa jogar com aquilo que Hall chama de "marcação de fronteira simbólica” (HAAL, 2000, p. 106). Não se identificar com o lugar de posição de sujeito que é mapeado nos discursos midiáticos sobre a América Latina pode ser mais simples do que se identificar com aquilo que se acha ser a representação do "ser americano". A identificação por si apenas não garante o reconhecimento e o pertencimento a um grupo. A identificação "obedece à lógica do mais-que-um" (HALL, 2000, p. 106) e isso é um complicador para esse jovem (VENERA; CONCEIÇÃO, 2012, p. 148, grifos das autoras).

Neste sentido, a considerável recusa à perspectiva da integração pode significar a recusa ao pertencimento/enquadramento nesta representação negativa, conjunto de memórias compartilhadas que evocam exemplos de problemas (sociais, econômicos, políticos), em contraste com a idealização da representação norte-americana. O único jovem que, na pesquisa das autoras, assumiu o pertencimento latino não o fez como motivo de orgulho, mas como um fardo que precisa ser abandonado ou carregado, sendo, por isso, motivo de vergonha, de ocultamento. Soma-se a isto o aumento 
do número de imigrantes bolivianos, paraguaios e uruguaios (e de outras nacionalidades) no país, os quais, no período de nossa coleta de dados, como pudemos verificar nos dados do SICREMI, estavam migrando para o Brasil, além dos stocks aqui já estabelecidos. Via de regra, estes grupos são colocados à margem da sociedade, buscando se estabelecer economicamente em trabalhos que variam da formalidade à informalidade, sendo constantemente relacionados a uma imagem negativa de insucesso econômico, pobreza e violência. Como afirma Erving Goffman (2012), a sociedade estabelece meios de categorizar as pessoas, imputando-lhes atributos que não precisam corresponder à realidade, mas que são construções sociais virtuais, expectativas normativas que constroem identidades sociais no imaginário coletivo e que são impostas sobre as pessoas. No caso específico dos imigrantes, o autor define este fenômeno como um estigma tribal, decorrente do critério da nacionalidade. Neste sentido, a recusa em pertencer a esta representação negativa tem relação com a operação da consciência que, desvinculada da experiência (e do conhecimento histórico/científico), projeta futuros que podem ser desastrosos: no entendimento dos jovens, a unificação poderia significar que suas vidas, no futuro, se aproximariam a este conjunto de estereótipos.

Esta recusa da parte dos jovens, da perspectiva de unificação do território, também encontra respaldo nos sentidos de interpretação que provêm do passado, e que podem estar dispostos na memória cultural e social destes jovens, a exemplo do modo como os latino-americanos foram representados pela historiografia nacional. Segundo Eujanian (1998), que reflete sobre o surgimento das repúblicas latino-americanas, os Estados Nacionais fundaram sua legitimidade, soberania, e também a ideia de cidadania, sobre discursos que enfatizavam diferenças culturais, políticas, sociais e, inclusive, étnicas. Complementando este argumento, para Heloísa Jochims Reichel (1998, p. 46),

[...] a historiografia nacional criou suas representações de nacionalismo desde o período colonial, é natural que as disputas por território, os antagonismos políticos e as vivências culturais aparentemente distintas tenham sido integradas à memória nacional, servindo à afirmação e à exacerbação dos sentimentos nacionais. Fronteiras e guerras externas são temas que aparecem frequentemente 
interligados nos estudos que focalizam as relações internacionais entre os povos e os Estados. Normalmente, as guerras geradas por questões de limites internacionais tornam-se acontecimentos que marcam a memória coletiva das sociedades que as vivenciam. Ao longo da história, as lutas contra inimigos externos têm contribuído para construir ou para fortalecer o sentimento de identidade na população, seja pela comemoração da vitória, seja pela frustração da derrota.

Assim, além das representações dos latinos enquanto imigrantes pobres, que permanecem como estigmas, ainda podemos acrescentar que, em alguma medida, este imaginário também carrega a ideia do outro como um possível inimigo externo.

Concluindo nosso texto, a partir dos nossos dados, talvez seja um exagero falar em sentimento de pertencimento dos jovens brasileiros à América Latina. O que se evidenciou foi algo que se aproximou mais de um sentimento de aproveitamento dos possíveis benefícios que a integração pode vir a trazer, no campo ideológico, do que uma escolha intencional de identificação com a cultura, história, condição social e memórias compartilhadas. Exatamente, se os dados que indicaram ausência de interesse no conhecimento da história e cultura da região, de fato, coincidirem com o desconhecimento dos jovens sobre a região (informação que nos escapou, dados os objetivos do questionário), o pequeno conhecimento/interesse encontrado por nossa pesquisa, da ordem de $30 \%$, não foi suficiente para reverter os estigmas sociais e as realidades virtuais que existem na sociedade sobre a América Latina, a ponto de possibilitar uma aceitação mais significativa da integração.

Ainda, convém avaliarmos este posicionamento de aversão dos jovens não apenas como reflexo do medo ao estrangeiro, típico das zonas de fronteira, também do medo à mudança. Segundo a teoria rüseniana, existe uma relação entre o entendimento processual da história e as identidades que promovem e aceitam as mudanças como algo positivo. Diante de poucos marcos referenciais que poderiam gerar reconhecimento e sentimento de pertencimento nos jovens, um modelo possivelmente estático da história - a se ver na avaliação de nação como algo natural $(0,51)$, a sugestão de mudança proposta pelo enunciado poderia ter sido interpretada pelos 
jovens como um problema, ao desestabilizar os marcos de identificação considerados tradicionais (a exemplo da nação/país).

Como pudemos observar, por mais que os documentos do MERCOSUL Educacional tenham avançado na consideração da história e cultura latino-americana em ambiente escolar, o que se evidenciou em nossos dados foi um interesse dos jovens enviesado pela ideia da autopromoção: interesso-me pela América Latina na medida em que ela possa me oferecer algo em troca. No interior de um regionalismo econômico, que se faz sob crescentes políticas neoliberais e que refletem na maneira como os jovens estão interpretando a realidade, reforçamos, aqui, urgentemente, o papel da História em ambiente escolar como o espaço do conhecimento do outro, da história e da cultura latino-americana, a se idealizar uma integração que se paute em princípios como humanidade, solidariedade e interculturalidade.

\section{REFERÊNCIAS}

ANDERSON, B. Comunidades imaginadas: reflexões sobre a origem e a difusão do nacionalismo. Trad. Denise Bottman. São Paulo: Companhia das Letras, 2008.

ANDERSON, P. Balanço do neoliberalismo. In: SADER, Emir \& GENTILI, Pablo (orgs.) Pós-neoliberalismo: as políticas sociais e o Estado democrático. Rio de Janeiro: Paz e Terra, 1995, p. 9-23.

ALVES, Tamar Kalil de Campos. Identidade(s) latino-americana(s) no ensino de História: um estudo em escolas de ensino médio de Belo Horizonte (MG). Uberlândia: Tese de Doutorado em Educação da Universidade Federal de Uberlândia, 2011.

BARNABÉ, I. R. UNASUL: desafios e importância política. Mural Internacional (Online), v. I, p. 40-48, 2011.

BITTENCOURT, C. M. F. Ensino de história da América: reflexões sobre problemas de identidades. Revista Eletrônica da ANPHLAC, v. 4, p. 01-11, 2005. 
BRASIL. Confira os blocos politicos e econômicos dos quais o País participa. Disponível em: <http://www.brasil.gov.br/governo/2012/07/confira-osblocos-politicos-e-economicos-dos-quais-o-pais-participa>. Acesso em: 28 fev. 2017.

BUCZENKO, G. L. Ensino de História da América e identidade histórica. In: Encontro Internacional da Associação Nacional de Pesquisadores de História das Américas, 2014, Niterói. Anais Eletrônicos do XI Encontro Internacional da ANPHLAC (Niterói, 2014). NITERÓI: ANPHLAC, 2014. p. 01-16.

CAZELOTO, E. Vínculos abstratos: a construção de um imaginário capitalista. Folios: Facultad de Comunicaciones, Universidad de Antioquia, Medellín (Colômbia), n. 29, p. 35-54, 2013.

CONCEIÇÃO, J. P. Entre muitos 'outros': ensino de história e integração latino-americana. História e Diversidade, v. 7, p. 7-23, 2015a.

. O peso do passado: currículos e narrativas no ensino de história das Ditaduras de Segurança Nacional em São Paulo e Buenos Aires. Tese (Doutorado em Educação) - Faculdade de Educação, Universidade Estadual de Campinas, Campinas, 2015b, 226 f.

CONCEIÇÃO, J. P.; DIAS, M. F. S. Ensino de História e consciência histórica latino-americana. Revista Brasileira de História (Online), v. 31, p. 173191, 2011.

CONCEIÇÃO, J. P. ; ZAMBONI, E.. A educação pública e o ensino de História da América Latina no Brasil e na Argentina. Práxis Educativa (Impresso), v. 8, p. 419-441, 2013.

CORSI, F. L. Os efeitos das políticas neoliberais na América Latina. In: CARVALHO, Edemir de (Org.). Perspectivas da globalização e de suas contradições no Brasil e na América Latina. 1ed.São Paulo: LCT Editora, 2011, v. 1, p. 121-150.

CORREO DEL ORINOCO. Tras reunión con María Emma Mejía|Hugo Chávez: Unasur garantiza permanencia de nueva independencia suramericana. 
Disponível em: <http://www.correodelorinoco.gob.ve/nacionales/hugochavez-llego-hora-union-suramericana/>. Acesso em: 18 jan. 2016.

COSTA, L. C. Os impasses do Estado capitalista: uma análise sobre a reforma no Brasil. Ponta Grossa: Editora UEPG; São Paulo: Cortez, 2006.

EUJANIAN, A. Diálogos e contatos entre a historiografia dos países americanos: uma visão na perspectiva argentina. In: MARFAN, M. A. (org.). O ensino de história e geografia no contexto do Mercosul. Brasília: MEC/SEF, 1998.

FREITAS, F. J. C. O Neoliberalismo e o Consenso de Washington. Revista Científica da UNESC, v. 2, p. 1-5, 2003.

GOFFMAN, E. Estigma: notas sobre a manipulação da identidade deteriorada. Rio de Janeiro: LTC, 2012.

GONZALEZ, M. P. Los jóvenes y la historia en la perspectiva de profesores de Brasil, Argentina y Uruguay. Clío \& Asociados. La Historia Enseñada 14, 152-166, 2010.

GOODSON, I. F. Currículo, narrativa e o futuro social. Revista Brasileira de Educação, Rio de Janeiro, v. 12, n. 35, p. 241-252, maio/ago. 2007.

HARVEY, D. Condição pós-moderna: uma pesquisa sobre as origens da mudança cultural. 22. ed. Tradução de Adail Ubirajara Sobral e Maria Stela Gonçalves. Rio de Janeiro: Edições Loyola, 2012.

HUNTINGTON, S. O choque de civilizações. Rio de Janeiro: Objetiva, 1997. IBARRA, D. O neoliberalismo na América Latina. Revista de Economia Política, vol. 31, n 2, 2011.

IPROFESSIONAL. Cristina Kirchner está en Caracas para participar de la Cumbre del Mercosur. Disponível em <http://www.iprofesional.com/ notas/192681-Cristina-Kirchner-est-en-Caracas-para-participar-de-laCumbre-del-Mercosur $>$. Acesso em: 18 jan. 2016.

JORNALISTAS LIVRES. O retrato de uma catástrofe. Entrevista a Marilena Chauí. Disponível em: 〈http://migre.me/w07p9>. Acesso em: 05 fev. 2017. 
KERSTENETZKY, C. L. O Estado do Bem-Estar Social na Idade da Razão. Campus: Rio de Janeiro, 2012.

Políticas sociais sob a perspectiva do Estado do Bem-Estar Social: desafios e oportunidades para o "catching up" social brasileiro. CEDE, UFF, Niterói, 2011.

MARTINS, C. E. Globalização, dependência e neoliberalismo na América Latina. São Paulo: Boitempo, 2011.

MERCOSUL. Plano Trienal e Metas do Setor Educacional. CMC/DEC. No 13/98. 1998. In: Sistema de Informação de Comércio exterior. Disponível em: <http://www.sice.oas.org/trade/mrcsrs/decisions/dec1398p.asp >. Acesso em: 09 jan. 2017.

MERCOSUL. Plano de ação do Setor Educacional do MERCOSUL. Brasília: Setor Educativo do Mercosul, 2011. Disponível em http://portal.mec.gov. br/index.php?option=com_docman\&view=download\&alias=8674-planoacao-2011-mercosul-pdf\&Itemid=30192. Acesso em 03 jul. 2018.

MERCOSUL. Setor Educacional do Mercosul. Plano trienal do setor educacional do Mercosul (1998-2000). Buenos Aires, Argentina, 1998a. Disponível em: http://edu.mercosur.int/pt-BR/tratados/finish/7-planosplanes/410-plano-trienal-1998-2000.html. Acesso em: 03 jul. 2018.

MERCOSUL. Setor Educacional do Mercosul. Plano do setor educacional do Mercosul (2001-2005). Buenos Aires, Argentina, 2001. Disponível em: http://sicmercosul.mec.gov.br/pt-BR/component/jdownloads/finish/7/413. html Acesso em: 03 jul. 2018.

MERCOSUL 2000: desafios e metas para o setor educacional. Declaração dos Ministros da Educação do Mercosul. Buenos Aires: [S. N.], 1996.

MERCOSUR. Plan del Sector Educativo del MERCOSUR 2006-2010. Buenos Aires: Sector Educativo del Mercosur, 2006. Disponível em http:// repositorio.educacion.gov.ar:8080/dspace/handle/123456789/66172. Acesso em 03 jul. 2018. 
O'GORMAN, E. La invención de América: investigación acerca de la estructura histórica del nuevo mundo y del sentido de su devenir. México: Fondo de Cultura Económica, 1958.

PARKER GUMUCIO, C. Identidad latina e integración sudamericana. In: ORO, A. P. (org.). Latinidade da América Latina. Enfoques sócioantropológicos. São Paulo: Aderaldo \& Rothschild, p. 60-96, 2008.

PRADO, Maria Lígia. O Brasil e a distante América do Sul. Revista de História USP. São Paulo, n. 145, p. 127 - 149, 2001.

REICHEL, H. J. Produção historiográfica no Mercosul: abordagens e tendências. In: MARFAN, M. A. (org.). O ensino de história e geografia no contexto do Mercosul. Brasília: MEC/SEF, 1998.

SACRISTÁN, José Gimeno. Saberes e Incertezas do Currículo. Porto Alegre: Penso, 2013.

SANTIAGO, L. A. S. Ensino de história da América no Brasil e na Argentina (1995-2010): um estudo comparativo sobre a ótica da política de integração regional e da identidade latino-americana. 2012, 317f. Tese (Doutorado em Educação) - Universidade Federal do Paraná, Curitiba, 2012.

O Ensino de História no Setor Educacional do MERCOSUL.

Percursos (Florianópolis. Online), v. 11, p. 01-17, 2010.

SANTIAGO, L. A. S.; RANZI, S. M. F.; CARVALHO, M. A.; CARNEIRO, M. E. F. Políticas educacionais integradoras: propostas curriculares do Brasil e da Argentina. Conjectura: Filosofia e Educação (UCS), v. 21, p. 144-181, 2016.

SISTEMA CONTÍNUO DE RELATÓRIOS SOBRE MIGRAÇÃO INTERNACIONAL NAS AMÉRICAS - SICREMI. 2015 Disponível em: <http://www.migracionoea.org/index.php/es/sicremi-es/acerca-de-sicremi. html>. Acesso em: 23 nov. 2015.

SILVA, E. B. Pós-fordismo no Brasil. Revista de Economia política, vol.14, n. 13, p. 107-120, 1994. 
SILVA, J. U. A Importância da Comunidade Andina para a Economia da América Latina. Revista Gerenciais (UNINOVE. Impresso), v.5, p. 71-82, 2006.

TELE SUR. Bolivia y Paraguay crearán un corredor ferroviário. Disponível em: < http://www.telesurtv.net/news/Bolivia-y-Paraguay-concretanproyecto-de-tren-bioceanico-20170102-0016.html . Acesso em: 02 jan. 2017.

ÚLTIMO SEGUNDO. Lula: América do Sul unida mexe com tabuleiro do poder mundial. Disponível em: <http://ultimosegundo.ig.com.br/ brasil/lula-america-do-sul-unida-mexe-com-tabuleiro-do-poder-mundial/ n1237678368789.html>. Acesso em: 18 jan. 2016.

UNASUR. CONSEJO DE EDUCACIÓN. Plan operativo quinquenal. Disponível em http://www.itamaraty.gov.br/images/ed_integracao/docs_UNASUL/ RES10.2014ANEXO.pdf. Acesso em 20 jan. 2017.

UNASUR. Tratado Constitutivo. Disponível em https://repo.unasursg. org/alfresco/service/unasursg/documents/content/TRATADO_ CONSTITUTIVO_DE_LA_UNION_DE_NACIONES_SURAMERICANAS. pdf?noderef $=44 \mathrm{~d} 79020$-e810-4d55-99f7-7f0ae5db23ec. Acesso em 03 jul. 2018.

VENERA, R. A. S.; CONCEIÇÃO, J. P. da. Tensões curriculares e narrativas: o ensino de História da América Latina. Tempo e Argumento, v. 04, p. 128151, 2012.

\section{Imagem}

HOMEM ANDANDO. Disponível em: <https://www.colourbox.com/ preview/8887548-phases-of-step-movements-man-in-walking-sequencefor-game-animation-on-white.jpg>. Acesso em: 08 fev. 2016. 


\section{PENSAR E VIVER A HISTÓRIA NAS FRONTEIRAS: OS JOVENS, A HISTÓRIA (ENSINADA) E AS IMAGENS SOBRE O CONTINENTE AMERICANO NO CONTEXTO MATO-GROSSENSE}

Renilson Rosa Ribeiro

Luís César Castrillon Mendes

Osvaldo Rodrigues Junior

"Nada do que um dia aconteceu pode ser considerado perdido" (Benjamin, 1985, p. 223)

\section{COMPLEXIDADES DO CAMPO: A HISTÓRIA ENSINADA ARTICULADA AO OFÍCIO DO HISTORIADOR}

A ação docente na área das Ciências Humanas torna-se cada vez mais uma atividade complexa e desafiadora. Complexa pela diversidade teórica e metodológica inerente ao campo; desafiadora por não se restringir apenas a uma mera transmissão do conhecimento, mas disponibilizar-se para melhoria qualitativa da sociedade. Assim, espera-se que as disciplinas constituintes desta área possibilitem leituras e interpretações de mundo, de forma a propiciar intervenções na vida prática.

No caso específico da História, disciplina que desde sua criação buscou legitimar Estados nacionais, a partir dos anos finais do Setecentos, possui uma peculiaridade adicional, na medida em que pode analisar, além de sincronicamente, os acontecimentos em uma perspectiva diacrônica. Desta forma, seu ensino exige maior capacidade de abstração por parte dos alunos, uma vez que o passado distante pode, também, ser o seu objeto de estudo.

Fazer viagens no tempo, ou seja, abstrair-se do tempo presente, contemporâneo, cotidiano, não é tarefa das mais exequíveis, principalmente por estarmos imersos em um regime de historicidade presentista, nos termos de François Hartog (2014). É natural o desinteresse em estudar algo localizado distante, tanto temporal quanto geograficamente da realidade do estudante. Se esse (ultra)passado acontecimento datado temporalmente, estranho e esquisito torna-se incompreensível, é porque talvez ele esteja 
desarticulado dos interesses, anseios e problemas da contemporaneidade vivida pelo aprendiz da História.

Torna-se descabida qualquer abordagem de conteúdo em sala de aula, seja qual nível for, desancorada nos problemas sociais, políticos, culturais, emocionais e econômicos do tempo presente, principalmente os que vão interferir diretamente na vida futura dos estudantes. Assim, assuntos como a crise política, econômica, moral e ética, tão característica em nosso país na atualidade, não podem ser excluídos das salas de aula. Iniciativas como Escola Sem Partido e as reformas propostas pela Base Nacional Curricular Comum (BNCC) e a Reforma do Ensino Médio podem (e devem) servir de exemplo para a articulação com outras medidas, em tempos pretéritos, que estabelecem estreitas relações e revelam contextos, muitas vezes, parecidos.

Uma incursão na História a contrapelo, como queria Walter Benjamim (1985), pode ser uma interessante e eficaz maneira de fazer com que o aluno tenha consciência de seu papel enquanto agente histórico, capaz de ler criticamente o mundo com a capacidade de modificá-lo qualitativamente. Nisto reside, a nosso ver, reside a importância da História e outras disciplinas afins: a capacidade para a formação da cidadania, na acepção plena do termo. E o que seria esta acepção plena? Certamente a resposta convergirá para outras respostas a outros questionamentos, tais como: quais concepções de História e cidadania estamos tentando forjar? Qual o sentido de se ensinar História nos dias atuais? Qual o seu valor? Quem são os agentes de minhas narrativas e das minhas aulas? Quais eventos eu seleciono e como são selecionados? O que estabelecem os currículos e a legislação vigente? As novas demandas sociais, os agentes historicamente silenciados, discriminados ou estereotipados nas narrativas estão se fazendo presentes? Nós, enquanto professores/historiadores, permitimos que eles saiam dos bastidores e assumam seus papéis de protagonistas?

Este artigo tem por objetivo analisar as ideias históricas de estudantes do Ensino Médio, em escolas públicas e privadas do estado de Mato Grosso, que vivem em regiões fronteiriças, no sentido de perceber de que forma eles elaboraram suas imagens sobre a História enquanto disciplina escolar e sobre a chamada História da América, enquanto partes constituintes da sua consciência histórica. 


\section{VIVENDO NAS FRONTEIRAS DO TEMPO: ENTRE A BRECHA TEMPORAL E O ETERNO PRESENTE}

De acordo com Luis Fernando Cerri (2011), os debates acerca da consciência histórica mobilizaram diversos autores, que apresentam distintas compreensões desse fenômeno humano. A principal divergência consiste no entendimento da consciência histórica enquanto algo próprio da condição humana, ou como atributo de uma parcela específica da sociedade.

Raymond Aron, na obra Dimensiones de la conciencia histórica (1962), defende que toda a sociedade é portadora de uma consciência histórica, mas que a sociedade europeia é a que tem uma consciência propriamente histórica. Partindo de uma perspectiva eurocentrada, Aron observa que "son los europeos los que han dado a los hindues la conciencia de su pasado. Es la historia científica, tal como practicaron los europeos, la que provee a los japoneses cultivados de la interpretación de su pasado" (ARON, 1962, p. 73).

Em direção semelhante, o filósofo Hans-Georg Gadamer afirma que "a consciência histórica que caracteriza o homem contemporâneo é um privilégio" (GADAMER, 1998, p. 17). Desta forma, ele define que a consciência histórica seria um estágio a ser atingido por alguns grupos sociais, o que condenaria os países periféricos a inconsciência histórica. Na compreensão deste autor, a relação entre a ciência especializada e o conhecimento de massas ocorreria apenas através das instituições de divulgação.

Outro autor a tratar da questão foi Philippe Ariès (1989), que indica que "[...] no antigo regime a consciência da história pouco existia, enquanto que na nossa época ela constitui o denominador comum das nossas sensibilidades. Assim, a ausência ou a presença de um passado particular distingue duas maneiras de se estar na história" (ARIÈS, 1989, s/p).

Desta forma, Aron (1962), Gadamer (1998) e Ariès (1998) identificam a consciência histórica enquanto um estágio ou privilégio de uma parcela da sociedade, mas especificamente do homem europeu moderno.

Agnes Heller (1993) e Jörn Rüsen(2001) entendem a consciência histórica como um fenômeno humano. Isto significa que, para eles, ela é fruto das condições de pensamento e não está restrita a grupos sociais 
específicos. Portanto, a consciência histórica seria "[...] toda produção de conhecimento que envolva indivíduos e coletividades em função do tempo" (CERRI, 2011, p. 28).

Heller (1993), na obra Uma Teoria da História, indica que,

[...] a consciência histórica é inerente ao estar no mundo (desde a percepção da historicidade em si mesmo, que se enraíza na ideia de que alguém estava aqui e não está mais, e de que eu estou aqui, mas não estarei um dia) e é composta por diversos estágios, que indicam a inserção da consciência em diferentes contextos da trajetória da humanidade (HELLER, 1993, p. 28).

Para Rüsen (2001), o homem deve agir intencionalmente no mundo e só pode fazer isso ao interpretá-lo e interpretar a si mesmo. Assim, tanto Heller quanto Rüsen entendem "que o pensar historicamente é um fenômeno, antes de qualquer coisa, cotidiano e inerente à condição humana" (CERRI, 2011, p. 29).

Sobre isso, Rüsen (2001, p. 78) afirma que "a consciência histórica não é algo que os homens podem ter ou não - ela é algo universalmente humano, dada necessariamente junto com a intencionalidade da vida prática dos homens". Logo, ele a define como "a soma de operações mentais com as quais os homens interpretam sua experiência da evolução temporal de seu mundo e de si mesmos, de forma tal que possam orientar, intencionalmente, sua vida prática no tempo" (RÜSEN, 2001, p. 57).

A aprendizagem histórica é o "[...] processo de mudança estrutural da consciência histórica" (RÜSEN, 2010, p. 51), que permite aos sujeitos não apenas adquirir ou ampliar o seu conhecimento do passado, mas mudar as formas como tratamos e utilizamos esse conhecimento. Tais formas, no entender de Rüsen (2010), podem variar dos modos tradicionais aos genéticos, passando pelo exemplar e crítico.

A formação histórica, entendida como "o conjunto das competências de interpretação do mundo e de si próprio, que articula o máximo de orientação do agir com o máximo de autoconhecimento, possibilitando assim o máximo de autorrealização ou de reforço identitário" (RÜSEN, 2007, p. 95), é responsável pela articulação entre as formas e os conteúdos históricos e os seus usos práticos. 
Destarte, há uma relação explícita entre as categorias consciência histórica, aprendizagem histórica e formação histórica no pensamento ruseniano. A consciência histórica é compreendida como uma ocorrência habitual da vida humana, que permite aos homens e mulheres orientar temporalmente as suas vidas. Essa consciência sofre alterações estruturais estimuladas pela aprendizagem histórica, enquanto processo de formação histórica, que possibilita o reforço identitário, permitindo aos sujeitos interpretarem o mundo e se autocompreenderem.

Algumas pesquisas empíricas intencionaram captar a consciência histórica. Youth and History, projeto liderado por Magne Angvik e Bodo von Borries (1997), contou com a participação de jovens de 15 anos de 25 países europeus, mais Israel e Palestina, no total de 32 mil entrevistados. Dentre os resultados destaca-se que "a influência do professor de história sobre as opiniões históricas do aluno é, no mínimo, limitada, como também é limitada a influência dos currículos oficiais de história sobre o trabalho do professor e seu resultado" (CERRI, 2011, p. 44).

Desde 2006, um projeto semelhante, intitulado Jovens e a História no Mercosul, vem acontecendo, organizado por pesquisadores brasileiros, argentinos e uruguaios. De acordo com Wilian Barom (2016), este projeto trata-se de, [...] um levantamento sobre a consciência histórica, cultura política e percepções da aprendizagem escolar de História de jovens entre 15 e 16 anos na América do Sul (Brasil, Argentina, Paraguai, Chile, Uruguai). Esta coleta de dados foi feita por meio de questionários impressos, para professores e alunos, em uma sala de aula por escola, em sete tipos de escolas (Pública de excelência, pública de periferia, pública rural, pública central, privada laica empresarial, privada laica comunitária e privada confessional). O que resultou num montante de 3246 questionários aplicados a alunos e 267 a professores. Com esta aplicação concluída em 2013, pesquisadores iniciaram um processo de análise destes dados, gerando inúmeras publicações científicas (BAROM, 2016, p. 71).

Este artigo, sem a pretensão de esgotar o tema, se propõe a contribuir para o conjunto de trabalhos que vêm analisando os dados obtidos no projeto. O objetivo foi averiguar o interesse dos jovens mato-grossenses pela história regional e dos demais países latino-americanos. A localização geográfica fronteiriça dos municípios pesquisados foi considerada 
na construção da hipótese de pesquisa, qual seja, a de que os jovens de Mato Grosso apresentam maior interesse pela história regional e latino-americana.

\section{HISTÓRIA E INTERVENÇÃO NA VIDA PRÁTICA: AS IMAGENS DA/NA FRONTEIRA A PARTIR DA ANÁLISE DOS DADOS}

Entre os anos de 2011 e 2012 foi aplicado um questionário composto por quarenta e três (43) questões para quatrocentos e quarenta e nove (449) estudantes de quinze (15) e dezesseis (16) anos de escolas públicas e privadas de Ensino Médio de três cidades do Estado de Mato Grosso Cáceres, Cuiabá (capital) e Rondonópolis, sendo cento e cinquenta e um (151) estudantes de Cáceres, cento e trinta e cinco (135) de Cuiabá e cento e sessenta e três (163) de Rondonópolis. Para a realização da referida pesquisa, foram envolvidos os pesquisadores e bolsistas ligados aos Departamentos de História da Universidade Federal de Mato Grosso (UFMT), do campus de Cuiabá e Rondonópolis, e do Curso de História da Universidade do Estado de Mato Grosso (UNEMAT), campus de Cáceres.

Dentre as questões, analisamos comparativamente a de número 18. Qual seu interesse sobre a história dos seguintes lugares, com destaque para as letras b. A história da minha região, e d. Outros países da América Latina. A opção por essa questão foi fruto da problemática da pesquisa acerca do interesse dos jovens mato-grossenses pela história regional e latino-americana.

$\mathrm{Na}$ letra b, identificamos os seguintes resultados (gráfico 1). 
Gráfico 1 - Comparação da distribuição das respostas dos estudantes das amostras brasileira e de cidades do Mato Grosso à questão 18b. Qual o seu interesse pela história dos seguintes lugares: a história da minha região, em porcentagens

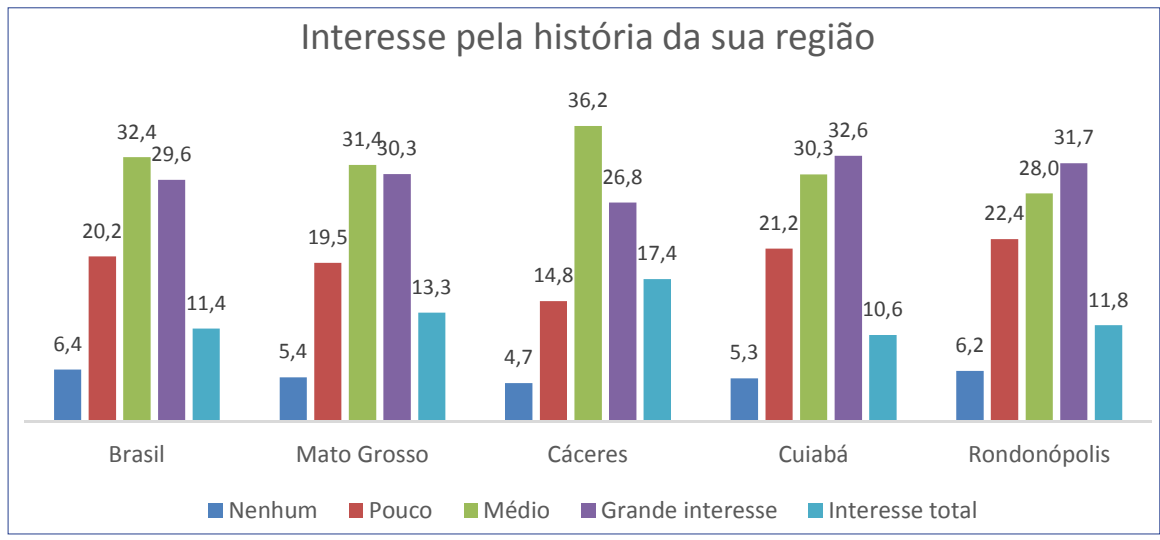

Fonte: Projeto Jovens e a História (2013). Elaboração dos autores.

Cáceres destaca-se por ter maior porcentagem de estudantes que demostra interesse total (17,45\%) pelas temáticas afeitas à História Regional, quando comparado com Cuiabá e Rondonópolis (principalmente entre os que demonstram interesse total - 10,61\% e 11,80\%, respectivamente). Se convertemos as respostas em uma escala que vai de -2 (nenhum interesse) a 2 (interesse total), as médias por cidade ficam assim: Cáceres tem a maior média (0,38), seguida de Cuiabá $(0,22)$ e Rondonópolis $(0,2)$. A distribuição da amostra de Mato Grosso, sem desagregação por cidade, apresenta 13,39\% de interesse total e 30,32\% de grande interesse, o que difere entre $1,5 \%$ e $2,0 \%$ das frequências da amostra do Brasil. Isto indica que, embora apareçam pequenas variações ocasionais, elas ocorrem em uma faixa muito restrita, dentro do desvio padrão da amostra nacional brasileira, sempre próximo a 1,0. Tem-se, portanto, um indicativo de que as amostras por cidade do Mato Grosso são consistentes com a amostra nacional (cuja média para a questão é de 0,19), sem apresentar diferenças acentuadas

O gráfico 2 oferece um parâmetro para comparação com as distribuições dos demais países da América do Sul selecionados para amostras da pesquisa. 
Gráfico 2 - Comparação da distribuição das respostas dos estudantes dos demais países da América do Sul à questão 18b. Qual o seu interesse pela história dos seguintes lugares: a história da minha região, em porcentagens

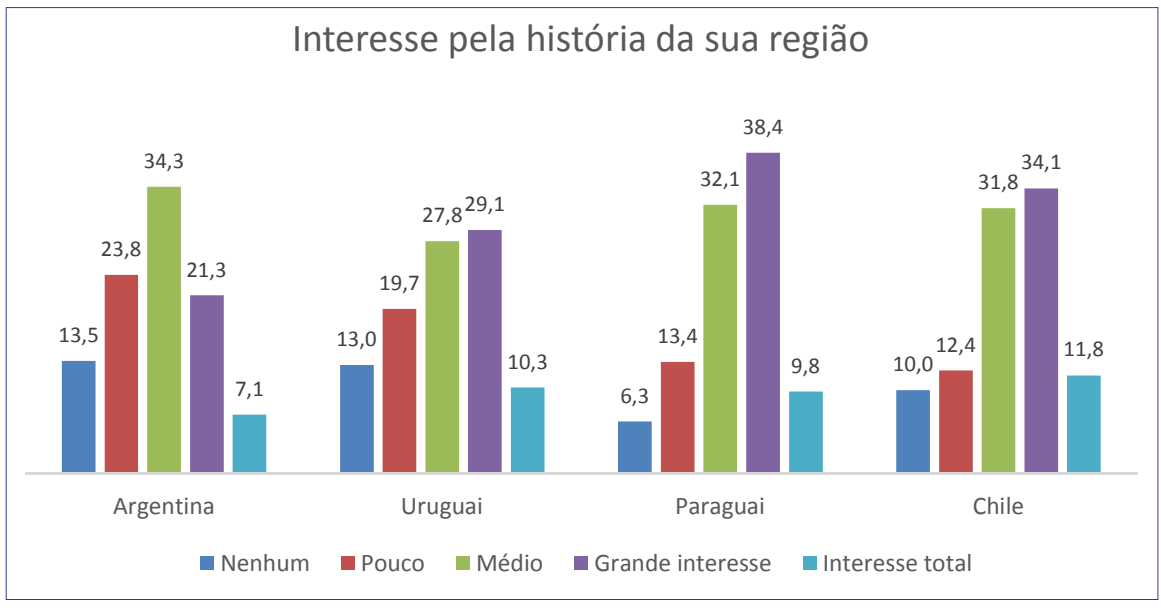

Fonte: Projeto Jovens e a História (2013). Elaboração dos autores.

Em relação aos demais países da América do Sul, o Chile destaca-se por ter uma maior porcentagem de estudantes que demostra interesse total $(11,8 \%)$ pelas temáticas afeitas à História Regional, uma leve vantagem sobre o Uruguai (10,3\%), o Paraguai (9,8\%), e a Argentina ocupa a última posição (7,1\%). Se compararmos à média do Brasil (11,4\%), observamos certa regularidade para baixo, no interesse total dos jovens pela História Regional na América Latina. Quando comparados os dados dos países da América Latina com os municípios de Mato Grosso, observa-se, também, certa regularidade no pouco interesse pelas temáticas regionais, com pequena diferença para Cáceres (17,4\%), 6\% acima da média nacional, 4,1\% da média estadual e 5,6\% acima da média chilena, a maior dentre os demais países da América Latina. Quando comparado ao dado da Argentina, a diferença sobe consideravelmente (10,3\%).

Com relação ao interesse dos estudantes nos outros países da América Latina, chegamos aos dados apresentados no gráfico 3. 
Gráfico 3 - Comparação da distribuição das respostas dos estudantes das amostras brasileira e de cidades do Mato Grosso à questão 18d. Qual o seu interesse pela história dos seguintes lugares: outros países da América Latina, em porcentagens

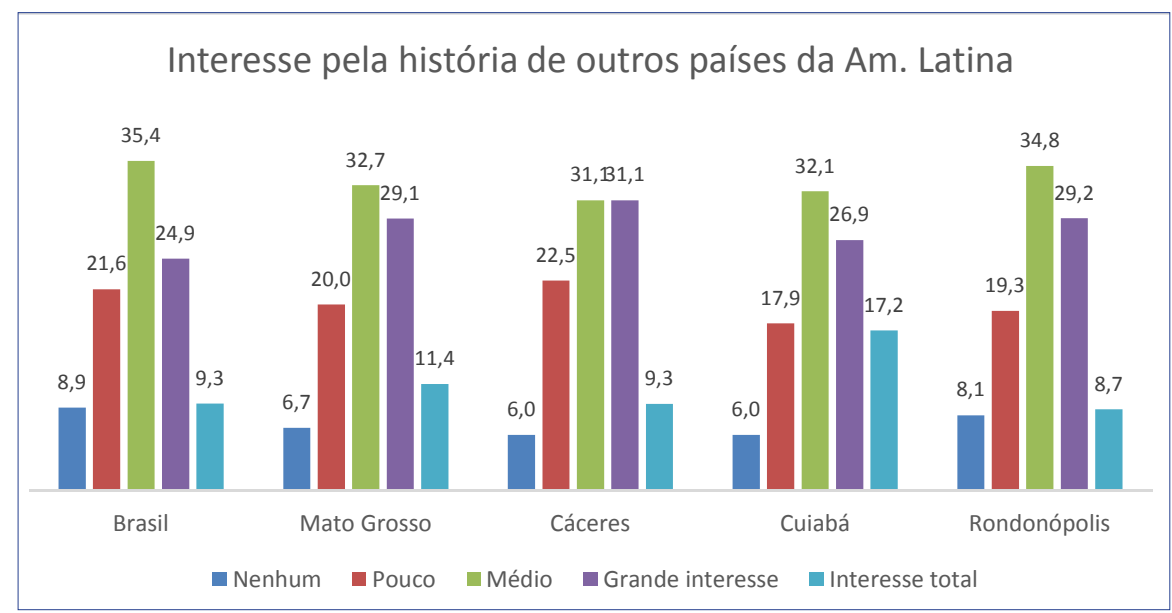

Fonte: Projeto Jovens e a História (2013). Elaboração dos autores.

No caso da apreciação do interesse pela história latino-americana, as amostragens de Mato Grosso registram, entre os estudantes, as médias de $29,1 \%$ de grande interesse e $11,4 \%$ de interesse total, o que, neste caso, difere aproximadamente entre 3,5\% e 4,0\% da amostra do Brasil. Merecem destaque, dentro do cenário mato-grossense, os dados de Cuiabá, que apontam que $17,2 \%$ dos estudantes têm interesse total pela temática, e 26,9\%, grande interesse. As amostras de Cáceres têm, respectivamente, $9,3 \%$ e $31,1 \%$. No caso de Rondonópolis, identificamos uma diferença da porcentagem do interesse total, quando comparado com Cuiabá: 8,70\%. Novamente, se trabalhamos com as médias aritméticas de cada município em questão, temos a confirmação de que o interesse por este recorte geográfico é levemente maior na capital do estado: 0,31 para Cuiabá, enquanto temos 0,15 em Cáceres e 0,11 em Rondonópolis. 
Gráfico 4 - Comparação da distribuição das respostas dos estudantes dos demais países da América do Sul à questão $18 \mathrm{~d}$. Qual o seu interesse pela história dos seguintes lugares: outros países da América Latina, em porcentagens

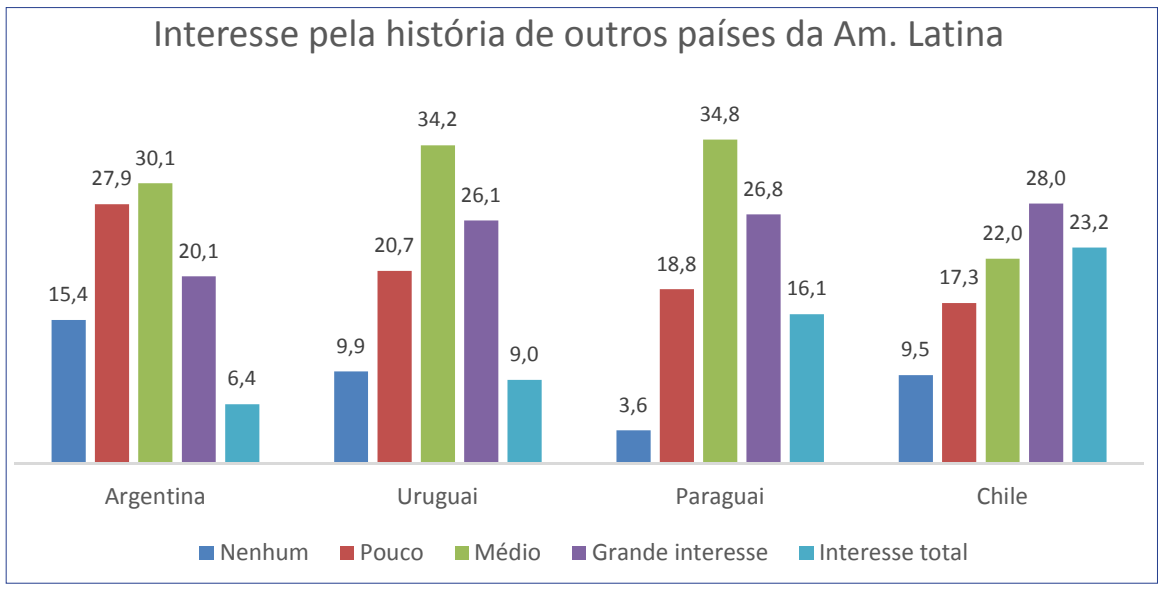

Fonte: Projeto Jovens e a História (2013). Elaboração dos autores.

No que se refere ao interesse pela história latino-americana nos demais países investigados, as amostragens novamente indicam o Chile $(23,2 \%)$ com o maior interesse total, seguido pelo Paraguai (16,1\%), Uruguai $(9,0 \%)$ e Argentina (6,4\%). Quando comparados aos dados de Mato Grosso, observa-se uma variação negativa de $11,4 \%$ no caso do Chile, e $4,7 \%$ para o Paraguai; e 2,4\% e 5\% positiva em relação a Uruguai e Argentina, respectivamente. Se comparamos o caso chileno ao brasileiro $(13,9 \%)$ e mato-grossense (11,8\%), novamente observamos o baixo interesse dos jovens pela história dos demais países da América Latina. Curioso notar que os jovens de Cuiabá $(17,2 \%)$ possuem mais interesse por essa temática do que os jovens de Cáceres (9,3\%), município mais próximo da fronteira.

Analisando qualitativamente os dados obtidos, observa-se pouco interesse dos alunos mato-grossenses pelo estudo pela História Regional, e também de outros países da América Latina, o que acaba por mitigar a hipótese previamente lançada, de que os habitantes de uma região fronteiriça teriam maior interesse por essas temáticas. 
No gráfico abaixo observa-se o interesse dos jovens pela história dos seguintes lugares:

Gráfico 5 - Respostas dos estudantes à questão 18. Qual seu interesse pela história dos seguintes lugares, em porcentagens

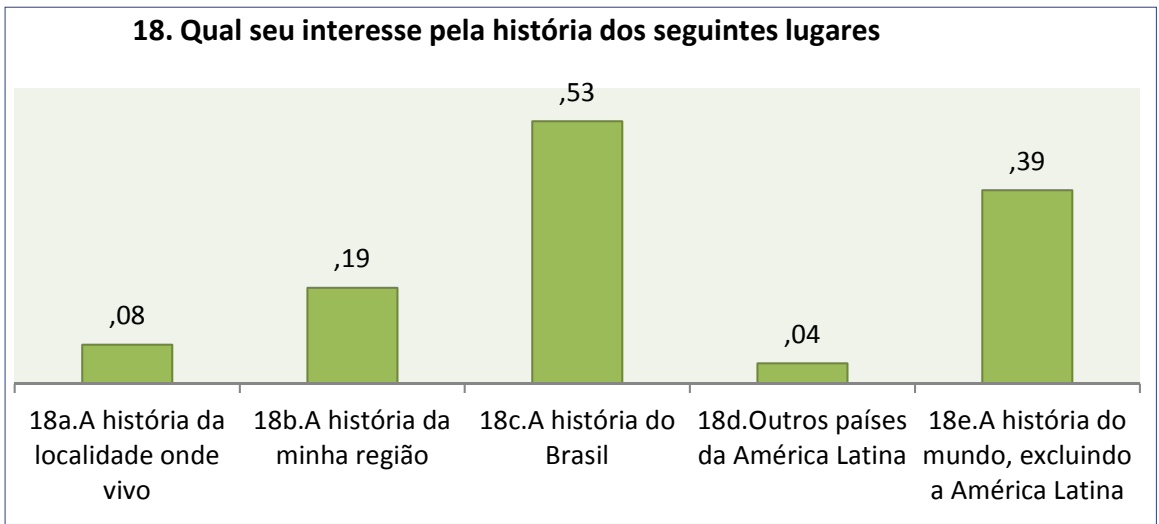

Fonte: Projeto Jovens e a História (2013). Elaboração dos autores.

Observando os dados do gráfico 5, podemos inferir que há maior interesse pela história do Brasil (53\%) e do mundo, excluindo a América Latina (39\%). Tal fenômeno evidencia o pouco interesse pela história da localidade onde os jovens vivem (08\%), sua região (19\%) e outros países da América Latina (04\%).

Elza Nadai (1993), em clássico artigo sobre a história do ensino de História no Brasil, localiza o nascimento da disciplina escolar de História no colégio D. Pedro II, no Rio de Janeiro, no ano de 1838. Filha da tradição francesa, a disciplina inicialmente configurou-se através das traduções dos compêndios franceses e da centralização no estudo da Europa Ocidental, dando pouco espaço para a História nacional. Somente com a Proclamação da República, em 1889, o ensino ganhou caráter fortemente nacionalista.

Naquele contexto, a concepção de História repousava "nas representações que procuravam expressar as ideias de nação e de cidadão embasadas na identidade comum de seus variados grupos étnicos e classes sociais constitutivos da nacionalidade brasileira" (NADAI, 1993, p. 149). Com isso, procurou-se criar uma ideia de nação totalizadora das raças. 
Vinculada ao conceito de progresso, a disciplina dedicava-se à civilização europeia ocidental, buscando identificar o Brasil a este bloco de países, principalmente a França. Desta forma, apesar de certa resistência de alguns profissionais da História, a América Latina manteve-se esquecida dos currículos.

Katia Abud (1998) observa que, "logo após a Revolução de 30 e a reorganização do Ministério da Educação e Saúde Pública, o então Ministro da Educação do Governo Provisório, Francisco Campos, comandou uma profunda modificação no sistema de ensino do país" (ABUD, 1998, p. 32).

Os programas e orientações metodológicas da Reforma Francisco Campos foram produzidos por comissões de especialistas que faziam parte de órgãos educacionais, sendo até hoje desconhecidos os nomes daqueles que formularam a proposta de História. Essa proposta abrangia a História Geral, do Brasil e da América de maneira a integrá-las na chamada História da Civilização.

A História da Civilização substituiu as antigas cadeiras de História Universal e História do Brasil, sendo o conteúdo integrado entre a chamada História Universal e a História do Brasil. O objetivo era "estabelecer uma estreita vinculação entre o estudo do passado nacional e americano com o passado europeu" (CASTRO, 1955 apud ABUD, 1993, p. 170). A História do Brasil e da América deveriam ser ensinadas de forma fragmentada, como reflexo da História europeia.

Apenas em 1942, o conjunto de decretos que ficou conhecido como Reforma Gustavo Capanema reestabeleceu o caráter autônomo da História do Brasil, aumentando, inclusive, a sua carga horária. A História da América só começa a aparecer nos currículos, com um espaço restrito, na década de 1950 ( ).

A recente polêmica envolvendo a produção da Base Nacional Comum Curricular (BNCC) permite observar permanências desse ranço eurocêntrico na história ensinada (RIBEIRO; RODRIGUES JUNIOR, 2017). A primeira versão, duramente criticada por apresentar uma perspectiva descolonizante, foi suplantada por uma terceira versão, que mantém o ensino de História eurocentrado. 
Os resultados da presente pesquisa permitem inferir que os currículos são fundamentais para o interesse ou desinteresse dos jovens estudantes por determinadas temáticas. A ausência da História da América dos currículos e da tradição escolar e a manutenção de uma perspectiva eurocêntrica corroboram para o pouco interesse dos jovens estudantes pela História Regional e dos demais países da América Latina, tendo em vista que eles não se sentem conectados aos hermanos latino-americanos.

Os resultados permitem, ainda, indagar de que forma os conteúdos sobre História Regional e História da América, ou a ausência deles, têm permitido aos jovens promoverem esses processos formativos. Isto demandaria um debate sobre os currículos, livros didáticos e demais materiais didáticos utilizados nas escolas públicas em Mato Grosso.

Na área de Ensino de História no Brasil, os debates e embates sobre o lugar do regional estão intimamente relacionados com as investigações direcionadas para a história local ${ }^{1}$. Para Maria Auxiliadora Schmidt (2007, p. 189), quando a aprendizagem histórica é pensada, precisa ser feita a seguinte questão: "por que trabalhar a história local?" Como respostas possíveis, a autora oferece as ideias de que a história local pode fornecer, aos estudantes, a busca da experiência do e no tempo, conforme defende Edward P. Thompson (1981), como critério para a seleção de conteúdos e a organização de temas históricos a serem ensinados e aprendidos a partir do princípio da formação da consciência histórica dos sujeitos (RÜSEN, 2009). Uma chave da compreensão das realidades locais estaria em sua relação com outras identidades locais, nacionais, latino-americanas e mundiais.

O universo dos alunos pesquisados, no caso de Mato Grosso, permite entender que o investimento dos professores de História e Geografia na história regional, pelo fato dos vestibulares das universidades públicas e privadas e concursos cobrarem esse tipo de conteúdo, não alterou significativamente o panorama de desinteresse dos jovens estudantes. Com a adesão das duas universidades públicas, UNEMAT e UFMT, ao Exame Nacional do Ensino Médio (ENEM), esse esforço tem sido ainda mais reduzido.

${ }^{1}$ Sobre o assunto, consultar a dissertação de mestrado de Jackson James Debona (2015), que buscou 
Por ser uma região de fronteira com a Bolívia, e ter uma história marcada pelas zonas de contato entre América Portuguesa e Espanhola no período colonial, Mato Grosso apresenta, em especial em Cuiabá e Cáceres, essas marcas sociais e culturais. Os cursos de formação de professores de História nessas cidades (UFMT/Cuiabá e UNEMAT/Cáceres) priorizaram, até o final dos anos 2010, conteúdos e fontes voltados para a História de Mato Grosso e História da América. No caso de Rondonópolis, onde também há um curso de Licenciatura em História no campus da UFMT, a temática da história regional era pautada na ênfase da localidade, ou seja, história da formação histórica da cidade, constituindo, por exemplo, a política de saída para capacitação dos professores em nível de pós-graduação².

Vale observar, também, que o Programa de Pós-graduação em História (PPGHIS) da UFMT, em Cuiabá, lócus de formação continuada de professores para o mestrado acadêmico, até a sua reestruturação, em 2010, para abertura do curso de doutorado, priorizava pesquisas sobre a história e historiografia de Mato Grosso, em interface com questões da História do Brasil e da América (GARCIA, 2003; JESUS, 2012; PERARO et al, 2011, AMEDI, 2012).

Contudo, observa-se que os esforços de inclusão das temáticas e de formação de professores para o trabalho com essas temáticas parecem não ter surtido, ainda, efeitos na prática docente. Assim, percebe-se o pouco interesse dos jovens estudantes de Mato Grosso pela História Regional e dos demais países da América Latina.

Concluindo, defendemos que esse interesse deve ser estimulado pelos processos formativos, que permitam aos educadores tratarem dos conteúdos de História Regional e da América, na direção de possibilitar uma aprendizagem histórica que permita mudanças estruturais na consciência histórica dos jovens, resultando em uma formação histórica que possibilite o reforço identitário, pois “(concretamente: todo sujeito nasce

\footnotetext{
${ }^{2}$ Partilhando dessa preocupação, Marcos Lobato Martins (2009, p. 143) conceitua a História Regional como aquela em que se "toma o espaço como terreno de estudo, que enxerga as dinâmicas históricas no espaço e através do espaço, obrigando o historiador a lidar com processos de diferenciação de áreas. A História Regional é a que vê o lugar, a região e o território como natureza da sociedade e da história, e não apenas como palco imóvel onde a vida acontece. Ela é História Econômica, Social, Demográfica, Cultural, Política etc., referida ao conceito chave de região".
} 
na história e cresce nela). O que o sujeito precisa é assenhorar-se de si a partir dela" (RÜSEN, 2007, p. 107).

\section{REFERÊNCIAS}

ABUD, Katia. O ensino de História como fator de coesão nacional: os programas de 1931. Revista Brasileira de História. São Paulo, n. 25/26, p. 163-174, set. 1992/ago. 1993.

. Formação da alma e do caráter nacional: ensino de história

na Era Vargas. Revista Brasileira de História. São Paulo, v. 18, n. 36, p. 103$114,1998$.

AMEDI, Nathália da Costa. A escrita da cidade: Cuiabá como objeto historiográfico. Revista Eletrônica Documento/Monumento. Cuiabá, v. 6, p. 73-86, 2012.

ANGVIK, Magne; BORRIES, Bodo von (eds.) Youth and History. A comparative European survey on historical consciousness and political attitudes among adolescents. Hambourg: Edition Körber-Stiftung, 1997. Vol. A.

ARIÈS, Philippe. A história marxista e a história conservador. In: O tempo da História. Rio de Janeiro: Francisco Alves, 1989, p. 30-47.

ARON, Raymond. Dimensiones de la Consciencia Historica. Madrid: Editorial Tecnos, 1962.

BAROM, Wilian C. C. As publicações do projeto Jovens e a História - 20072014. História \& Ensino. Londrina, v. 22, n. 1, p. 71-90, jan./jun. 2016.

BENJAMIN, Walter. Obras escolhidas, vol. 1. São Paulo: Brasiliense, 1985.

CARDOSO, Fernando Henrique. Desenvolvimento e identidade latinoamericana. Nossa América, Revista Memorial da América Latina. São Paulo, n. 23, 2006.

CERRI, Luís Fernando. Ensino de história e consciência histórica: implicações didáticas de uma discussão contemporânea. Rio de Janeiro: Ed. FGV, 2011. 
DEBONA, Jackson James. Entre o regional e o nacional: Mato Grosso do Sul nos livros didáticos de História - PNLD 2011. Dissertação (Mestrado em História) - Universidade Federal de Mato Grosso, Cuiabá, 2015.

GADAMER, Hans-Georg. Problemas epistemológicos das ciências humanas. In: FRUCHON, Pierre (Org.). O problema da consciência histórica. Rio de Janeiro: Editora da FGV, 1998.

GARCIA, Romyr Conde. Mato Grosso (1800-1840): crise e estagnação do projeto colonial. Tese (Doutorado em História Econômica) - Universidade de São Paulo, São Paulo, 2003.

HARTOG, François. Regimes de historicidade: presentismo e experiências do tempo. Belo Horizonte: Autêntica, 2014.

HELlER, Agnes. Uma teoria da História. Rio de Janeiro: Civilização Brasileira, 1993.

JESUS, Nauk Maria de. A capitania de Mato Grosso: história, historiografia e fontes. Revista Territórios e Fronteiras. Cuiabá, vol. 5, n. 2, p. 93-113, jul. dez. 2012.

MARTINS, Marcos Lobato. História Regional, In: PINSKY, Carla Bassanezi (Org.). Novos temas nas aulas de história. São Paulo, Contexto, 2009, p. 135-152.

NADAI, Elza. O ensino de História no Brasil: trajetórias e perspectivas. Revista Brasileira de História. São Paulo, n. 25/26, p. 143-162, set. 1992/ ago. 1993.

PERARO, Maria Adenir; BORGES, Fernando Tadeu de Miranda; JOANONI NETO, Vitale. Notas sobre a produção historiográfica acadêmica de Mato Grosso. In: GLEZER, Raquel (Org.). Do passado para o futuro: edição comemorativa dos 50 anos de ANPUH. São Paulo: Contexto, 2011, p. 145-166.

RIBEIRO, Renilson Rosa; RODRIGUES JUNIOR, Osvaldo. O labirinto das identidades no Brasil: Currículo(s) de História para os anos iniciais do Ensino Fundamental. In: RIBEIRO JÚNIOR, Halferd Carlos; VALÉRIO, 
Mairon Escorsi (Org.). Ensino de História e Currículo: reflexões sobre a Base Nacional Comum Curricular, formação de professores e prática de ensino. Jundiaí: Paco Editorial, 2017, p. 83-112.

RÜSEN, Jörn. Razão histórica. Brasília: Editora da Universidade de Brasília, 2001.

. História Viva. Brasília: Editora da Universidade de Brasília,

2007.

- ¿Que es la cultura historica? Reflexiones sobre una nueva manera de abordar la historia. [s.l.], [s.n.], 2009. . Jörn Rüsen e o ensino de História. Curitiba: Ed. UFPR, 2010. . Aprendizagem histórica: fundamentos e paradigmas. Curitiba: W.A Editores, 2012.

SADER, E. Introdução. In: SADER, E.; JINKINGS, I.; MARTINS, C. E.; NOBILE, R. (Coords.). Latinoamericana: enciclopédia contemporânea da América Latina e do Caribe. São Paulo: Boitempo, 2006. p. 29-32.

SCHMIDT, Maria Auxiliadora. O ensino de história local e os desafios da formação da consciência histórica. In: MONTEIRO, Ana Maria; GASPARELLO, Arlette M.;

MAGALHÃES, Marcelo S. (Org.). Ensino de história: sujeito, saberes e práticas. Rio de Janeiro: Mauad X; FAPERJ, 2007, p. 187-198.

THOMPSON, Edward P. A miséria da teoria ou um planetário de erros: uma crítica ao pensamento de Althusser. Rio de Janeiro: Jorge Zahar Ed., 1981. 


\section{O QUE TODO ESTUDANTE DE HISTÓRIA GOSTARIA QUE SEU PROFESSOR SOUBESSE, MAS TINHA MEDO DE DIZER}

Luis Fernando Cerri

Não nos enganemos com a paráfrase/paródia que o título deste posfácio faz com o filme de Woody Allen, de 1972. Não se tem a pretensão aqui de representar, de forma completa, o pensamento e as opiniões de todos os estudantes, e menos ainda se imagina que os estudantes de hoje tenham medo de dizer algo ao professor. Também era assim com o filme, ao abordar o tema da sexualidade no início dos anos 1970: a pretensão do diretor passava longe de querer esclarecer tudo. Pelo contrário, ao usar um humor caótico, ironizava o quanto havia de desconhecimento e preconceito em pleno período de revolução sexual. Paralelamente, guardadas todas as enormes diferenças entre os casos, estamos diante de um tema que, ao mesmo tempo, parece suficientemente conhecido e, mesmo assim, segue sendo objeto de dúvidas e desconhecimentos: o que pensam os estudantes, como se relacionam com a História na escola e na vida, como veem e agem na política, como avaliam a si mesmos.

Desta pesquisa foi possível traçar quadros sobre os diversos aspectos da realidade da aprendizagem e das ideias dos jovens, como fica claro nos textos anteriores, e nas demais publicações já surgidas a partir desta base de dados. Neste posfácio, a intenção é complementar esse panorama. Nele, encontramos situações sobre as quais não tínhamos nenhuma ideia prévia, e que nos surpreenderam, assim como constatamos realidades que já conhecíamos a partir de outras fontes de pesquisa, assim como pelo olho clínico que se desenvolve na profissão de professor. Mesmo nestes casos em que já eram esperados os resultados que encontramos, foi possível dimensionar melhor os fenômenos e responder sobre a sua medida, intensidade e dimensão.

\section{ELEMENTOS SOBRE O ESTADO DA RENOVAÇÃO METODOLÓGICA NO ENSINO DA HISTÓRIA}

Quando nos perguntamos sobre que métodos de ensino devem predominar nas aulas de História, parece claro para todos que as aulas 
expositivas e o uso do livro didático ou similares (apostilas, xerox, etc.) são importantes, mesmo porque estão nas origens da disciplina escolar como marcas de nascimento. Mas qual é a sua presença e a sua proporção na atualidade, em que sucessivas reformas educacionais, mudanças curriculares, novas concepções de ensino e aprendizagem disseminadas nos cursos de formação inicial e continuada, entre outros fatores, têm defendido continuamente o uso de métodos ativos em sala de aula? O gráfico 1 traz alguns elementos para a resposta.

Esta foi uma das questões do instrumento de coleta de dados que figurou igualmente para estudantes e professores, com a devida adaptação das respostas (por exemplo, na afirmativa a, Os estudantes ouvem as minhas exposições sobre o passado, a redação para estudantes é Ouvimos as exposições dos professores sobre o passado, e assim sucessivamente). Evidentemente, não se trata de uma medida in loco do que acontece nas salas de aula, mas do dado da percepção de docentes e discentes ouvidos na pesquisa, percepção esta que aparece mais próxima nos itens 13a, 13c e 13g. Dentre estes, os dois de maior concordância média, 13a e 13g são esperados: aulas expositivas e uso de material didático impresso são os cânones metodológicos, não apenas da disciplina, mas da própria cultura escolar. O livro didático parece reinar absoluto, o que fortalece o argumento de que qualificá-lo cada vez mais é um objetivo central para a melhoria da Educação, dada a presença desse recurso/ prática no relato de professores e estudantes. Mais de um século e meio de existência não enfraqueceram essas práticas na sala de aula: pelo contrário, são elas que predominam, em um indicativo de que todas as vertentes de metodologias ativas de aprendizagem não lograram chegar a uma posição dominante no sistema escolar, apesar de poderem ser rastreadas nas outras respostas, como veremos abaixo. Em suma, a aula magistral e o manual escolar permanecem ocupando o centro da cena. Ainda entre as concordâncias entre professores e estudantes, é relativamente inesperado o resultado do item 13c, ou seja, a percepção, coincidente entre discentes e docentes, de que nas aulas são trabalhadas diferentes explicações sobre o que ocorreu no passado. O predomínio de métodos tradicionais e o reconhecimento de que diferentes explicações 


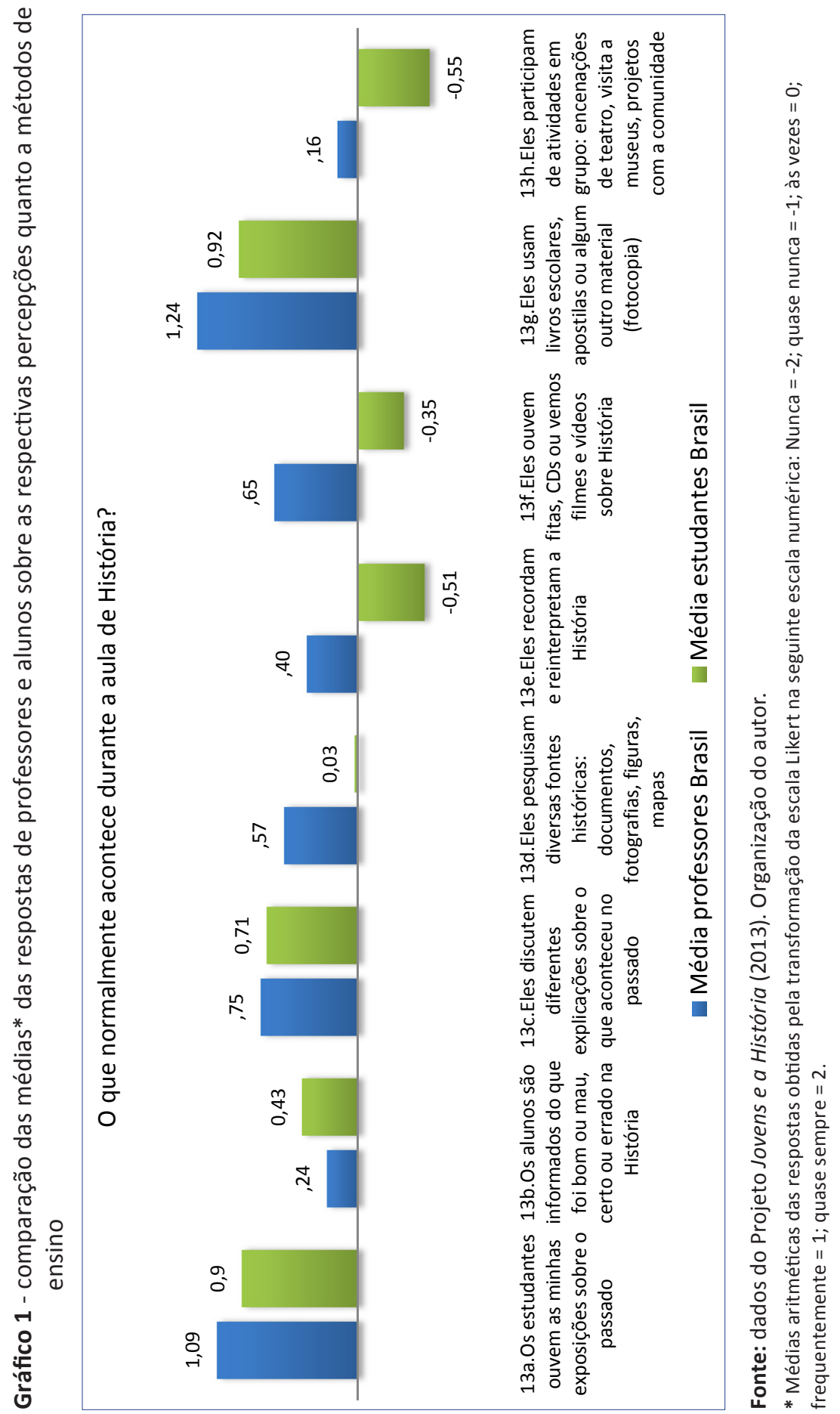


sobre o passado têm lugar frequente na sala de aula de História colocam por terra, a um só tempo, as acusações dos movimentos que enxergam doutrinação a cada passo dos professores de História, e que atribuem aos métodos ativos de Educação as mazelas da qualidade de ensino. Pelo menos nesta ampla amostra, nem uma coisa nem outra se confirmam. No que tange à análise das políticas curriculares e de formação de professores, estamos muito longe de poder afirmar que os métodos ativos no ensino de História foram aplicados em larga escala e fracassaram, o que poderia dar guarida à interpretação de que os problemas de aprendizagem que verificamos no dia a dia resultariam de falta de abordagens tradicionais. Pelo contrário, depois de todas essas décadas de debates e incentivos a métodos e abordagens baseados nas críticas aos elementos tradicionais do ensino da disciplina, é patente que estes predominam; mais que isso, os resultados aqui expostos corroboram a ideia de que esses elementos são parte do problema. Obviamente, isto merece um debate mais aprofundado e sofisticado, cujo espaço não é este.

No que tange aos métodos ativos, professores e estudantes divergem, nas médias, e para os primeiros estes métodos são mais frequentes que para os segundos. Isto pode resultar de diversos fatores: a interferência do pesquisador, por exemplo, estimulando o docente a intensificar a percepção da frequência de práticas que são vistas como corretas ou desejáveis pela universidade e pelos gestores da Educação. Outra hipótese é que professores e estudantes percebem de modo diferente a frequência de determinadas atividades no tempo, ou atribuem sentidos diferentes a determinadas atividades. Um trabalho com documento histórico reproduzido no livro didático pode ser entendido, pelos estudantes, apenas como um trabalho com o livro didático, por exemplo. De qualquer modo verifica-se, para os professores, uma percepção de que os trabalhos mais ativos e protagonizados pelos estudantes (itens 13d, 13e, 13f, 13h) são menos frequentes, com destaque para saídas de campo. Em todos estes itens, os docentes apontam uma média baixa, mas a média dos estudantes é ainda mais baixa. 


\section{(NÃO) DANDO CONTA DE UMA TAREFA BÁSICA COM CONHECIMENTO HISTÓRICO}

A aprendizagem da história é um fenômeno complexo e multifacetado. Nossa aproximação caracteriza-se por uma ampla base empírica, mas, em contrapartida disso é que pudemos nos dedicar a um número relativamente limitado de aspectos da aprendizagem. Nestes termos, foi possível tratar um objetivo básico do ensino de História, que é reconhecer e ordenar fenômenos no tempo, o que, apesar das limitações que se possa apontar, é um índice significativo de uma aprendizagem exitosa. Em outras palavras, por mais que tenhamos um leque bastante aberto de objetivos para o ensino da disciplina, o seu ponto de partida passa pelo reconhecimento de uma lógica geral da experiência histórica. A questão foi criada especificamente para esta pesquisa sul-americana, e ofereceu, aos respondentes, um conjunto de cinco períodos ou processos relevantes e gerais sobre a história da América, processos esses comuns à História nacional dos países envolvidos; ou seja, poderiam ser identificados e ordenados sem um estudo formalizado de história da América. O enunciado foi o seguinte: Coloque cada resposta segundo a ordem que aconteceram na história da América, marcando desde 1 para mais antigo até 5 para o mais recente. Não deixe de usar os números 2, 3 e 4 . As respostas foram colocadas na seguinte ordem: Época da colonização portuguesa/ espanhola, Tempo em que só havia sociedades indígenas, período de ditaduras militares, Independência e Imigração. A resposta correta, portanto, seria a sequência 21534, embora a questão permitisse uma ambiguidade, que se refere à imigração. Quando elaboramos a questão, pensamos nos processos de imigração vividos na América no final do século XIX e início do XX; entretanto, como não quisemos dar referências cronológicas, a palavra também pode ser associada aos processos de chegada dos primeiros colonizadores europeus. Entendendo dessa maneira, a sequência 21534 também poderia ser aceita como correta. A tabela 1 registra as frequências e porcentagens destas duas sequências nas respostas, que podem ser consideradas corretas, e as demais sequências, que não atendem ao enunciado. 
Tabela 1 - Análise das respostas de ordenamento de processos da História da América*

\begin{tabular}{|c|c|c|c|}
\hline País & Respostas & Frequência & Porcentagem \\
\hline \multirow{4}{*}{ Argentina } & 21534 & 344 & $37,4 \%$ \\
\hline & 21543 & 186 & $20,2 \%$ \\
\hline & Outras respostas & 389 & $42,3 \%$ \\
\hline & Total & 919 & $100,0 \%$ \\
\hline \multirow{4}{*}{ Brasil } & 21543 & 432 & $18,8 \%$ \\
\hline & 21534 & 338 & $14,7 \%$ \\
\hline & Outras respostas & 1530 & $66,5 \%$ \\
\hline & TOTAL & 2300 & $100,0 \%$ \\
\hline \multirow{4}{*}{ Uruguai } & 21543 & 53 & $24,7 \%$ \\
\hline & 21534 & 47 & $21,9 \%$ \\
\hline & Outras respostas & 115 & $53,5 \%$ \\
\hline & Total & 215 & $100,0 \%$ \\
\hline \multirow{4}{*}{ Paraguai } & 21435 & 22 & $18,4 \%$ \\
\hline & 21534 & 10 & $8,4 \%$ \\
\hline & Outras respostas & 87 & $73,2 \%$ \\
\hline & Total & 119 & $100,0 \%$ \\
\hline \multirow{4}{*}{ Chile } & 21543 & 29 & $15,9 \%$ \\
\hline & 21534 & 19 & $10,4 \%$ \\
\hline & Outras respostas & 134 & $73,6 \%$ \\
\hline & Total & 182 & $100,0 \%$ \\
\hline
\end{tabular}

Fonte: dados do projeto Jovens e a História no Mercosul (2013). Elaboração do autor.

* Foram omitidas as respostas em branco.

O dado que mais salta à vista é que as respostas erradas (outras respostas) são a maioria em todos os países, exceto na Argentina, mas é bom não perder de vista que, na tabela acima, não foram consideradas as respostas em branco. Não responder tanto pode significar desconhecimento, incapacidade de interpretar o que foi solicitado ou mesmo recusa em responder, por qualquer motivo. A amostra brasileira nos coloca exatamente no meio da classificação, em terceiro lugar, atrás de Argentina e Uruguai, e à frente de Uruguai e Chile, mais próximos destes que daqueles. Embora esses resultados precisem ser confirmados em outras pesquisas e não 
signifiquem, por si mesmos, um ranking sobre a qualidade dos resultados de aprendizagem histórica, permitem ter uma noção geral dessa realidade naquele momento.

Destacamos a necessidade de outros estudos e reflexões sobre o que, efetivamente, esse indicador significa, ou seja, trata-se de um indicador de maior ou menor aprendizagem histórica? De que tipo? Feita essa ressalva, no geral, o que o resultado indica é um alerta sobre a qualidade do ensino de História no subcontinente, ainda que seja lícito discutir que a questão engloba apenas um aspecto limitado da qualidade do ensino. Nesta seara, o resultado, novamente, deve ser pensado como um indício da realidade, e dependente de outros estudos com outras amostras e métodos.

\section{SABE-SE MAIS DE IDADE MÉDIA QUE DE DITADURA MILITAR}

Os gráficos 2 e 3 referem-se a questões que permitem uma análise do ponto de vista da atualização historiográfica dos conteúdos de ensino e aprendizagem abordados na amostra.

Gráfico 2 - Médias* das respostas dos estudantes da amostra brasileira quanto à associação de afirmativas com a Idade Média

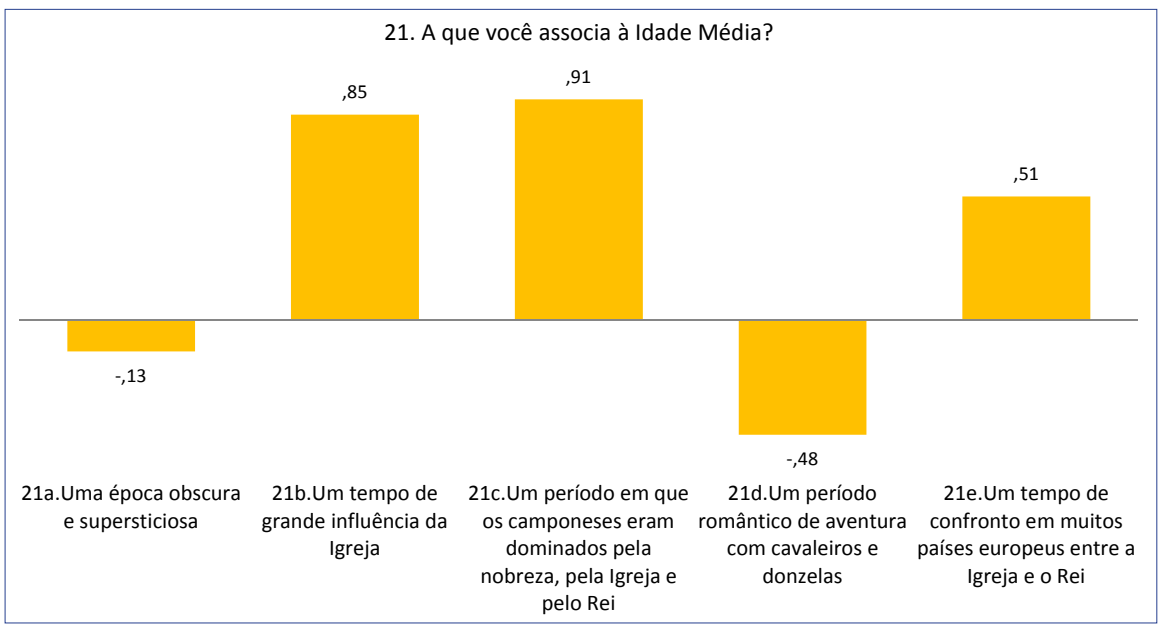

Fonte: dados do Projeto Jovens e a História (2013). Organização do autor.

* Médias aritméticas das respostas obtidas pela transformação da escala Likert na seguinte escala numérica: Discordo totalmente $=-2$; discordo $=-1$; concordo em parte $=0$; concordo $=1$; concordo totalmente $=2$. 
O questionamento à ideia de que a Idade Média foi uma idade das trevas, presente na afirmação 21a, só é encontrado na bibliografia especializada ou na escola, em livros didáticos e aulas em que predominem uma visão geral do período, que é sustentada nos trabalhos dos medievalistas a partir dos anos 1960, que colocaram essa visão em xeque. A média para a afirmativa 21a, que é de leve rejeição ao que está afirmado, é um indicativo de que, na escola, o estado atual do conhecimento histórico sobre o tema está em vias de predominar. Na mesma direção, são amplamente aceitas, pelos estudantes, as afirmativas 21b, 21c e 21e, as quais, se não são exclusivas da historiografia predominante, são consistentes com ela. Por outro lado, a afirmativa $21 \mathrm{~d}$ expressa uma visão romântica da Idade Média, com ampla presença nos meios de comunicação de massa e nos jogos eletrônicos, herdeira do romantismo novecentista europeu, obviamente rechaçada pela historiografia e pela escola.

O resumo do gráfico 2 pode ser escrito assim: pela ação da escola, principalmente, a visão historiográfica mais recente e predominante na academia foi ensinada e assimilada pelos estudantes.

Gráfico 3 - Comparação de médias* das respostas dos professores e estudantes da amostra brasileira quanto à associação de afirmativas com os regimes militares

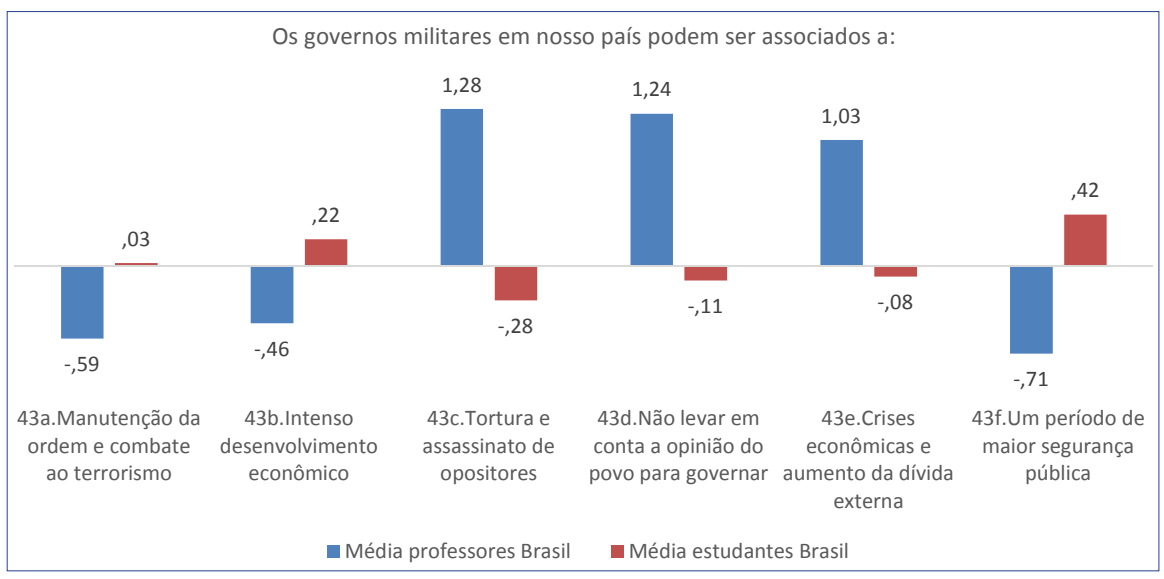

Fonte: dados do Projeto Jovens e a História (2013). Organização do autor.

* Médias aritméticas das respostas obtidas pela transformação da escala Likert na seguinte escala numérica: Discordo totalmente $=-2$; discordo $=-1$; concordo em parte $=0$; concordo $=1$; concordo totalmente $=2$. 
O gráfico 3 traz mais uma das questões que foram feitas igualmente a professores e estudantes, ao contrário da anterior, feita apenas aos estudantes. A colocação em contraste, das médias das respostas de professores e estudantes, dá sequência ao raciocínio, uma vez que consideramos que os professores de História têm incorporado a visão predominante na academia sobre os governos militares brasileiros.

A gritante divergência entre a visão dos professores (e da historiografia atual) e a visão dos estudantes leva-nos a resumir este resultado de forma inversa ao resultado da questão sobre a Idade Média: a visão historiográfica mais recente e predominante na academia não foi assimilada pelos estudantes, provavelmente porque não foi suficientemente ensinada. A hipótese a considerar aqui é que, por diversos fatores, mas principalmente pelo fato de que o formato dos currículos de História no Brasil, hoje, faz predominar um encaminhamento enciclopédico e linear de processos históricos, os tópicos da História recente ficam para o final do ano e não chegam a ser ensinados, ou são ensinados de forma aligeirada e superficial, no contexto de final de ano e necessidade de vencer o conteúdo.

Com isso, chegamos a um resultado em que ficam evidentes os avanços do ensino de História ligados à atualização historiográfica, quando tratamos de Idade Média, mas não quando tratamos de regime militar brasileiro. Deve-se levar em conta que os dados foram coletados antes das manifestações de 2013 e do enorme refluxo ideológico que se seguiu nas campanhas eleitorais de 2014 e do impeachment de Dilma Roussef. No contexto de uma enorme polêmica, subitamente abafada, sobre a Base Nacional Comum Curricular, estes dados ganham uma relevância e uma urgência ainda maior. Cabe à comunidade responder o que é mais premente em termos da contribuição da História para a formação para a cidadania.

\section{OS INTERESSES DOS ALUNOS POR HISTÓRIA (OU: UMA BOA IDEIA DE POR ONDE COMEÇAR)}

Esta pesquisa também permite traçar um panorama sobre quais são os principais pontos da lógica do interesse dos estudantes na História, como já vimos no texto da professora Leia Santiago e do professor Wilian 
Barom neste livro. Esse interesse refletirá, como veremos a seguir, tanto a própria cultura escolar e o ensino de História, com suas tradicionais prioridades temáticas, cronológicas e de recorte espacial, como também algumas características da cultura dos próprios jovens e de suas famílias. Trata-se de um item fundamental para o estabelecimento de currículos e programas, para os gestores, também para a orientação dos professores em sala de aula, no sentido de que essas informações podem ser utilizadas na definição de pontos de partida, ritmos e ênfases que repousam sobre as margens de governabilidade que os docentes têm sobre suas próprias aulas e planejamentos.

O gráfico 4 apresenta, em formato de linha, a média de interesse dos estudantes por períodos históricos geralmente abordados nos currículos. Em todos os países pesquisados, o desenho dessa linha resultante é praticamente o mesmo, e o que varia de maneira uniforme são as distâncias dessas linhas em relação ao eixo $x$ ou, em outras palavras, os padrões médios de intensidade do interesse declarado pelos respondentes em cada amostra nacional.

Gráfico 4 - Comparação de médias* das respostas dos estudantes de cada amostra nacional quanto ao interesse nos períodos da História

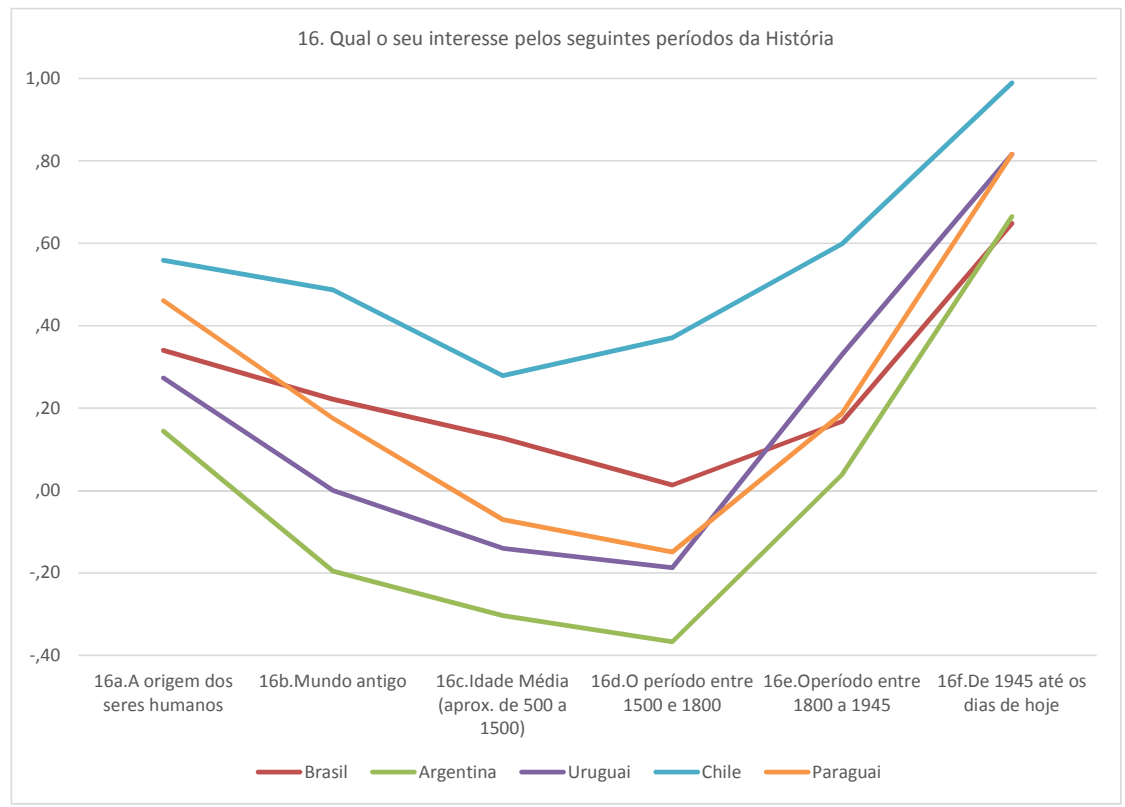

Fonte: dados do Projeto Jovens e a História (2013). Organização do autor.

* Médias aritméticas das respostas obtidas pela transformação da escala Likert na seguinte escala numérica: nenhum interesse $=-2$; pouco interesse $=-1$; interesse médio $=0$; interesse grande $=1$; interesse muito grande $=2$. 
O período de interesse mais baixo entre os estudantes, exceto na amostra chilena, é aquele conhecido como Idade Moderna ou, no caso da História da América do Sul, o período que corresponde à colonização dos espaços que, hoje, constituem os atuais países do subcontinente. No caso dos estudantes chilenos, o menor interesse médio é pela Idade Média. Em todos os casos, o maior interesse é pelo período chamado de história recente, que engloba, aproximadamente, o período após a Segunda Guerra Mundial e a atualidade. No caso da América do Sul, estaríamos tratando de processos delimitados no tempo por termos como populismo ou regimes nacional-populares, desenvolvimentismo, ditaduras militares, redemocratização e globalização/neoliberalismo. Por fim, o segundo período de maior interesse médio dos estudantes da amostra é referente à origem dos seres humanos, que pode remeter aos períodos anteriores às grandes civilizações e à invenção da escrita e, no contexto da América do Sul, à história indígena, notadamente da ocupação do espaço do continente americano e as primeiras experiências sociais e políticas destes grupos originários.

Esses resultados permitem indicar que os dois processos históricos de maior interesse dos estudantes são exatamente os aqueles que recebem menor interesse e espaço por parte dos programas oficiais. O primeiro por tratar de assuntos que, tradicionalmente, não se referiam à História, mas à Antropologia, a partir de um conceito já superado, mas ainda muito influente na prática, de que sem documentos - escritos - não há história. $\mathrm{O}$ segundo, de modo semelhante, também se bate com conceitos já superados na teoria, mas ainda influentes, de modo tácito, nas práticas dos currículos, materiais didáticos e aulas, que é a ideia de que os acontecimentos recentes não devem ser abordados pela História, porque sobre eles é mais difícil a isenção e a objetividade do historiador/professor. Esse preconceito tácito é alimentado por um currículo praticado que tende a prejudicar o estudo dos temas mais recentes, bem como por um fenômeno político recente que busca impor, ao docente, um ensino asséptico, desprovido de discussão de valores e posicionamentos, como se tal coisa fosse possível na História e demais Ciências Humanas. Pode-se perguntar, por fim, se o alto interesse dos alunos nos dois assuntos menos abordados, pelo currículo e pelas aulas, 
está relacionado; ou seja, se haveria uma relação inversamente proporcional entre o fato de ser abordado na escola e o interesse dos alunos. Os resultados do gráfico 5 podem lançar alguns dados a mais para revisar esta hipótese.

O gráfico 5 retoma o tema também tratado, neste livro, nos textos de Leia Santiago, Renilson Ribeiro, Luís César Mendes, Osvaldo Rodrigues Jr. e Wilian Barom, e traz resultados que caminham no sentido contrário aos resultados do gráfico 4 , no sentido de que reproduzem mais diretamente as práticas curriculares comuns em História, que privilegiam dois recortes clássicos: a História nacional e a História universal ou da civilização, que geralmente é uma história da Europa e suas origens médio-orientais, bem como suas projeções posteriores às grandes navegações. Em que pese a intensidade dos interesses expressos nas médias, que é distinta para cada amostra (por exemplo, as respostas dos jovens chilenos e paraguaios mostraram maior interesse geral pela História, independentemente do recorte proposto), fica claro que os dois recortes de maior interesse são, respectivamente, a história nacional e a história mundial excluindo os outros países da América Latina. Recortes menos frequentes nos currículos, como a história local, regional e da América Latina são igualmente rejeitados pelos jovens, com exceção dos chilenos, que mostram interesse significativo pela história da América Latina; e dos jovens paraguaios, em cuja amostra encontramos o maior interesse médio pela história local, regional e da América Latina.

Esse resultado é significativo para ajudar na interpretação do gráfico 4, que parecia favorecer a ideia de que, quanto mais frequente na escola, menos interessante seria um assunto para os estudantes. Como vimos, os resultados do gráfico 5 não corroboram a hipótese desta relação. 
Gráfico 5 - Comparação de médias* das respostas dos estudantes das amostras de cada país quanto ao interesse pela História em diferentes recortes espaciais

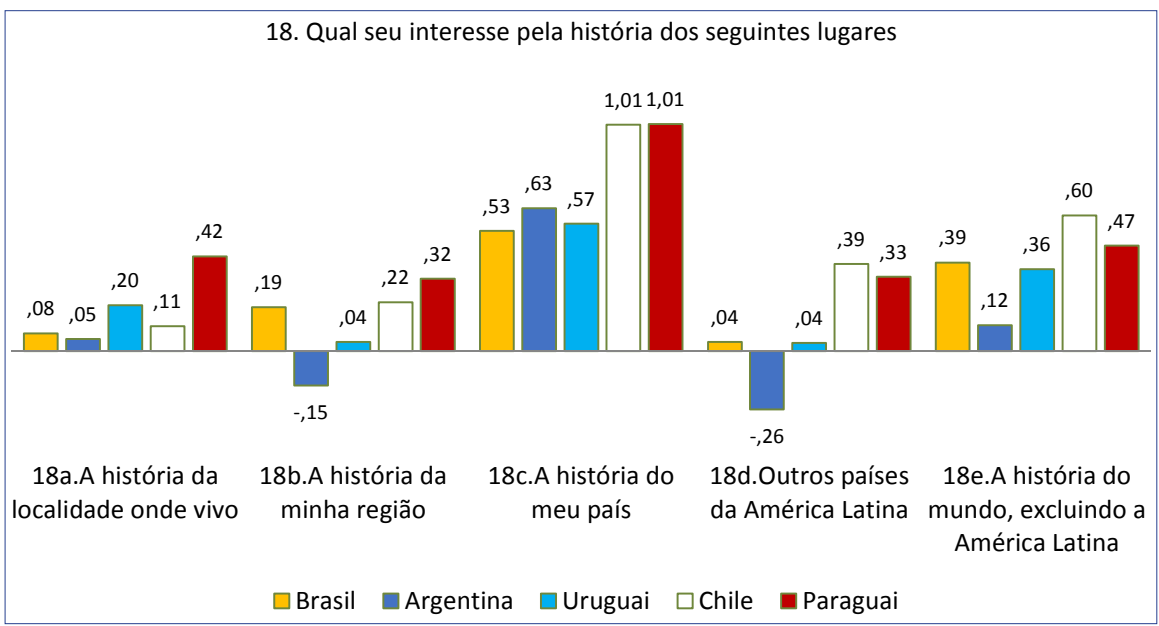

Fonte: dados do Projeto Jovens e a História (2013). Organização do autor.

* Médias aritméticas das respostas obtidas pela transformação da escala Likert na seguinte escala numérica: nenhum interesse $=-2$; pouco interesse $=-1$; interesse médio $=0$; interesse grande $=1$; interesse muito grande $=2$.

O gráfico 6, por sua vez, aponta uma hierarquia de temas de interesse dos estudantes brasileiros, com destaque para a aparente contradição entre o tema com maior interesse médio manifestado e o tema de menor interesse. Em outras palavras, enquanto a história da própria família é o item com maior média, a vida cotidiana das pessoas comuns é o único item com médias negativas de interesse, na outra ponta da hierarquia dos interesses. Também são objeto de interesse relativamente pequeno $o$ desenvolvimento da democracia, reis, presidentes e personagens politicamente importantes no poder, o desenvolvimento da agricultura, da indústria e do comércio e a formação das nações. A história política, portanto, que está entre as mais frequentes na prática curricular, recebe pouca atenção dos alunos, seja no que tange à democracia e sua história, ou à ação de próceres; seja, ainda, na trajetória de constituição das nações. Os temas que mais recebem atenção compõem uma mistura de individualismo (a história da própria família) e temas vibrantes, como guerras, ditaduras, aventureiros e descobridores, 
ou que angariam preocupação, como é o caso da interferência do homem no meio ambiente.

Gráfico 6 - Comparação de médias* das respostas dos estudantes brasileiros e desagregada por sexo quanto ao interesse por distintos temas da História

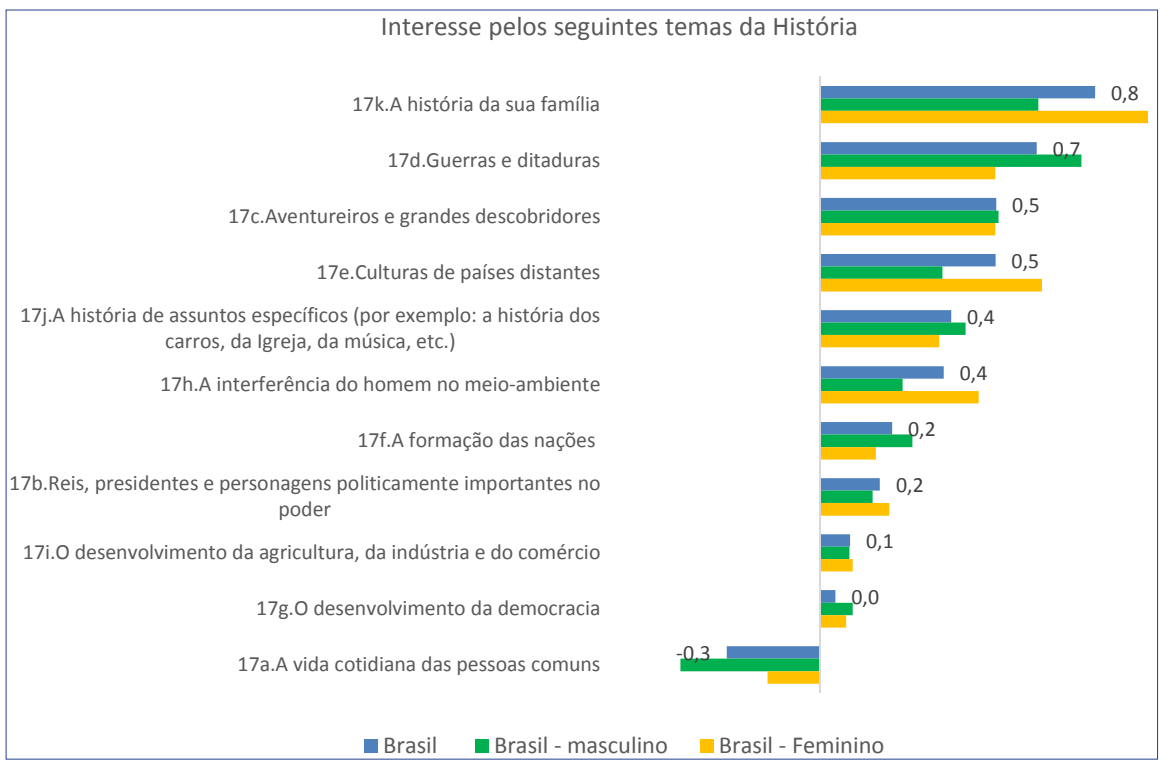

Fonte: dados do Projeto Jovens e a História (2013). Organização do autor.

* Médias aritméticas das respostas obtidas pela transformação da escala Likert na seguinte escala numérica: nenhum interesse $=-2$; pouco interesse $=-1$; interesse médio $=0$; interesse grande $=1$; interesse muito grande $=2$.

Uma abordagem tomando em conta o sexo dos respondentes indica alguns fatores que são indiferentes a essa variável: o interesse em aventureiros e grandes descobridores, reis, presidentes e personagens politicamente importantes, desenvolvimento da agricultura, indústria e comércio, bem como o desenvolvimento da democracia. Entretanto, são afetadas pela variável sexo a história da própria família, a cultura de países distantes e a interferência do homem no meio ambiente, temas em que as estudantes revelam interesse médio significativamente maior que seus colegas do sexo masculino, enquanto guerras e ditaduras recebem maior atenção destes.

A combinação de resultados do gráfico 4 e do gráfico 6 sugere que uma estratégia de ensino e aprendizagem potencialmente positiva para 
conseguir atenção e engajamento dos estudantes passa por construir conhecimentos novos, no sentido de articular a história da família do aluno com processos históricos do Brasil recente, bem como da história mundial. Assim pode-se promover, pelo menos em parte, a aproximação entre o conhecimento histórico escolar e a experiência histórica mais próxima do aluno, através da memória e dos documentos. Apesar de esta ser uma estratégia comumente usada nas séries iniciais e nos primeiros contatos com a disciplina de História no $6^{\circ}$ ano do Ensino Fundamental, não é uma estratégia disseminada no ensino da história contemporânea e do ensino do Brasil recente, que ocorre em anos mais avançados da Educação Básica. A pesquisa mostrou, em suma, que tal interesse permanece até o final da Educação Básica, e aproveitá-lo parece uma das chaves para um ensino e uma aprendizagem mais significativos.

Em suma, o passado na escola é o passado acadêmico. Não raro, não ocorre identificação alguma entre os estudantes e este passado que lhes é apresentado, mesmo no caso da História do Brasil que, tradicionalmente, reserva seu palco a elites brancas e a personagens masculinos. Trata-se de um passado que faz sentido para o perfil do estudante destinatário do ensino de História original, no século XIX, voltado à formação dos quadros dirigentes do Estado imperial, e depois da República elitista e socialmente excludente. A massificação do acesso à educação, no final do século XX, estabelece um forte descompasso entre os que estão representados na História e aqueles que a estudam, em termos de classe social, gênero e etnia, pelo menos. Por outro lado, todos sabem história, mesmo que não conheçam a (ou não se reconheçam na) História da escola e da academia, mas a sabem, cada um a partir de seu próprio ponto de vista, pessoal, familiar e comunitário. Os resultados acima permitem afirmar, tanto que esse encontro entre as histórias ainda está por ocorrer, quanto a urgência desse mesmo encontro, antes do que os estudantes tendem a não entender a história estudada como sua. 


\section{RECONHECE-SE A EXPLORAÇÃO COLONIAL, MAS NÃO SUA RELAÇÃO COM A EXPLORAÇÃO ATUAL}

O gráfico 7 traz a distribuição das respostas dos estudantes brasileiros quanto a uma situação hipotética que remete a políticas afirmativas compensatórias para as populações que sofreram prejuízos históricos em seu desenvolvimento social, educacional, econômico e político por conta de situações de trabalho compulsório, sofrimento de preconceitos e exploração econômica. Tem-se, então, um indicativo de como o conhecimento histórico interage com decisões políticas, no caso, de apoio ou rejeição a tais políticas, e as justificativas perante as possibilidades de sua efetivação.

Gráfico 7 - Distribuição das respostas da amostra brasileira de estudantes à questão sobre indenizações a descendentes de povos explorados, em porcentagens

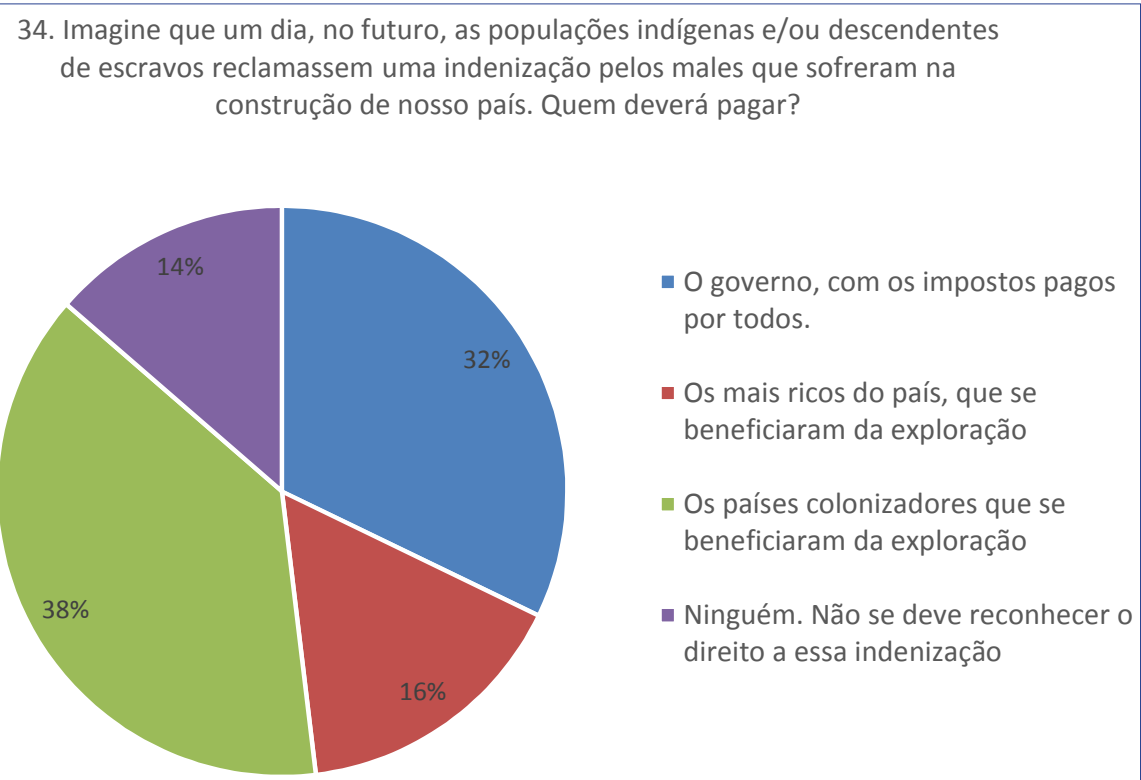

Fonte: dados do Projeto Jovens e a História (2013). Organização do autor.

A negação pura e simples da indenização hipoteticamente proposta é abraçada por uma minoria dos respondentes, $14 \%$ apenas, o que sugere a prevalência de solidariedade social, pelo menos no momento em que os dados foram coletados. A adesão à resposta de que quem deve pagar a 
indenização são os países colonizadores indica a presença predominante da ideia de um hiato entre o período de exploração legalizada e legitimada de negros índios (geralmente vista como o período colonial) e a atualidade. O que se passa é que, via de regra, tradicionalmente negros e índios aparecem durante o ensino do período colonial, geralmente em condições desfavoráveis, como escravidão, vítimas de conquista armada e exploração, e tendem a desvanecer no restante do currículo. Seja como for, as respostas sugerem que a ampla maioria dos estudantes não associa a exploração sofrida por estes grupos no passado com a riqueza dos grupos sociais dominantes na atualidade. Deste modo, a solidariedade social que transparece no resultado indica a solução para o problema a partir dos recursos do Estado nacional; ou seja, com os impostos pagos por todos. Embora os benefícios da exploração destas populações tenham sido apropriados privadamente, a solução encampada por grande parte dos estudantes da época é de socializar a indenização através do governo, ou de transferi-la a países estrangeiros, como se a dominação colonial anulasse a dominação social interna à colônia e à nação dela resultante.

\section{HISTORICIDADE, A FRONTEIRA FINAL?}

Em termos de objetivos do ensino de História, um dos mais complexos é o ensino e a aprendizagem da noção de historicidade, ou seja, da efetiva compreensão do passado como um tempo tão distinto do nosso que, se nós nascêssemos e crescêssemos nele, não pensaríamos como pensamos. Esta noção vincula-se à capacidade de entender que o outro é e pensa diferentemente porque as suas condições de vida, de cultura, de valores e assim por diante, são substantivamente diferentes da nossa. A consequência política da aprendizagem e da vivência da historicidade é a tolerância, pois, uma vez que se entende que os outros são diferentes por sua trajetória diversa, como pessoa, no tempo e no espaço, não se entende mais à diferença como resultado da falta, e nem a própria condição como uma espécie de plenitude que se espera que os outros alcancem em algum momento. A compreensão da historicidade colabora, enfim, com o efeito de descentrar o indivíduo e o grupo, enfraquecendo o etnocentrismo, fonte de grande parte dos conflitos e extremismos contemporâneos. Psicologicamente, a 
empatia é o correspondente do domínio da noção de historicidade, pois leva a uma disposição compreensiva e compassiva em relação ao outro, ao entender que, embora nossos trajetos sejam distintos, está aberta a porta para compreender os aspectos comuns para além das diferenças.

O gráfico 8 indica os resultados dos estudantes da amostra brasileira diante do desafio de colocar-se no lugar de outro rapaz ou moça no século XVII, diante de uma situação de serem forçados a um casamento por interesse. Há uma sucessão de tarefas progressivamente mais complexas no desenvolvimento da resposta. A primeira é reconhecer o período de que trata o século XVII e, em seguida, recordar-se de algumas características que tenham aprendido sobre o período. Por fim, e então entra o domínio da noção de historicidade, compreender que as características do período condicionariam a sua própria resposta diferentemente das características atuais; ou seja, criados em outros tempos, seríamos pessoas diferentes das que somos. Trata-se de ser capaz de colocar-se no lugar do outro para imaginar como ele poderia responder, em vez de responder por si mesmo, na atualidade. Entretanto, foi exatamente isso que a maioria fez.

As alternativas 31a e 31e expressam noções contemporâneas, derivadas de um aprofundamento do individualismo e de uma revisão do amor romântico que datam, pelo menos, do final do século XIX. Ainda que os estudantes nunca tenham ouvido falar do assunto nestes termos, na escola, pressupomos que eles têm a ideia de que o casamento tinha outro significado social e função no passado mais distante, tanto pelas narrativas escolares sobre a diplomacia entre os estados monárquicos quanto, entre outros fatores, pelas representações artísticas, reproduzidas na mídia, em que esse tema aparece frequentemente, por exemplo, nas múltiplas versões e adaptações da peça Romeu e Julieta. Argumentamos, então, que não é por falta de conhecimento, mas por incapacidade ou inabilidade de fazer o movimento de colocar-se no lugar do outro, que a ampla maioria dos respondentes escolhe as alternativas 31a e 31e, e respondem por si mesmos, não pelas suas contrapartes imaginárias no passado. Ou, em outras palavras, não distinguem estas contrapartes de si mesmos, indicando pouca capacidade de aplicar o conhecimento de que o passado é substantivamente diferente do presente em todas as suas dimensões. 

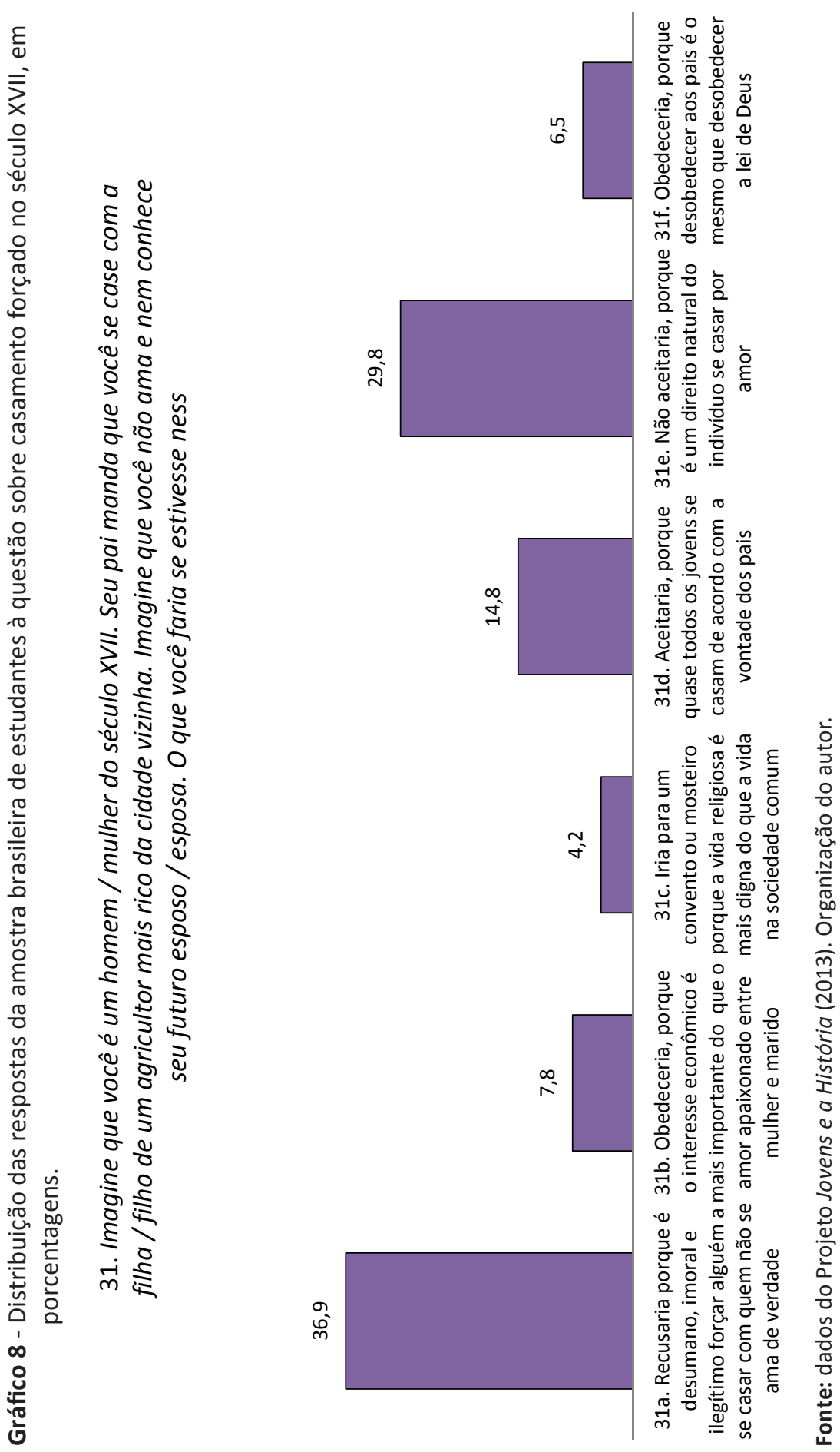
Por outro lado, um terço dos alunos respondeu assinalando as alternativas 31b, 31c, 31d ou 31f, que são compatíveis com atitudes e pensamentos possíveis no século XVII a esse tipo de problema, o que indica que, parcialmente, esse objetivo educacional foi atingido. A desagregação por tipo de escola indica que não se trata de um problema referente à qualidade de ensino, no que tange aos aspectos organizacionais e materiais que diferenciam escolas públicas e privadas. Pelo contrário, os dados apontam que os resultados variam muito pouco, no que toca a este sensível objetivo de ensino e aprendizagem. Se desagregamos os dados, separando os que responderam corretamente à questão que pedia para ordenar os cinco processos históricos, a distribuição da resposta sofre uma pequena variação. Os que respondem historicamente têm uma proporção apenas um pouco maior de estudantes que respondem corretamente a ordenação (37,9\% de ordenações corretas entre os que respondem historicamente contra 31,1\% dos que respondem não historicamente).

No ensino de História, o domínio prático da noção de historicidade não é somente um objetivo em si mesmo, também uma ponte para a formação do pensamento crítico. Dominar e colocar em uso a noção de que tanto eu quanto os outros pensamos como pensamos devido às nossas condições históricas de vida, principalmente as culturais: esta é a ponte para o entendimento da relatividade de toda opinião, sem o que se fica prisioneiro de um olhar binário e empobrecido de verdade única (a nossa) contra múltiplas mentiras ou enganos (os outros). O apagamento da historicidade é uma condição necessária, ainda que não suficiente, para o etnocentrismo. Afirmando ao revés, a superação do etnocentrismo e do autoritarismo passa pela historicidade, de um jeito ou de outro.

Há uma diferença, também, entre saber que o outro é diferente por sua história, e aplicar esse conhecimento, simulando, com sucesso, o pensamento do outro a partir de suas condições específicas. Esse exercício de letramento histórico (LEE, 2006) depende de se descentrar, de abstrair-se de si e colocar-se no lugar do outro, o que é, por sua vez, condição necessária para aprender e desenvolver a empatia, um sentimento/conhecimento cujo efeito político é a tolerância, como foi dito acima, sem a qual a completa 
convivência democrática não se viabiliza. Liga-se, assim, o desenvolvimento da noção de historicidade com o papel do ensino de História na formação cidadã.

O resultado encontrado pode ser pensado como um fator por trás da disseminação do discurso de ódio e a busca de alternativas autoritárias por parte de jovens, que se verificou mais claramente a partir de meados de 2013, momento em que a coleta de dados desta pesquisa já estava encerrada. Evidentemente não é o único fator, tanto porque já estava presente antes dessa nova conjuntura da cultura política nacional, quanto porque não está claro que tal postura política abranja a maioria dos jovens, como ocorre com as respostas não históricas da pesquisa.

Há que se considerar, também, que não se trata apenas de um desafio cognitivo para professores e estudantes. É preciso considerar fatores do desenvolvimento psicológico dos estudantes, no caso adolescentes, para os quais o contexto psicológico é de afirmação de si mesmos perante o mundo adulto, bem como de sua identificação perante o grupo, processos que podem ser dificultadores do colocar-se no lugar do outro, em muitos casos.

\section{MUITAS PONTAS SOLTAS}

Resta assumir, por fim, que muitas das possibilidades de análise destes dados não puderam ser exploradas simplesmente porque não houve tempo e gente suficiente para fazer todas as perguntas e todas as investigações possíveis. Em vez de algo a desanimar os envolvidos, trata-se de deixar as pontas soltas para estimular novas pesquisas e novos atamentos para refazer os fios da meada, que necessariamente passam por redes de colaboração, por continuar as iniciativas de investigação em perspectiva coletiva.

\section{REFERÊNCIA}

LEE, Peter. Em direção a um conceito de literacia histórica. Educar, Curitiba, n. especial, p. 131-150, 2006. 
APÊNDICE A - AMOSTRA DETALHADA POR CIDADE 


\section{Estudantes}

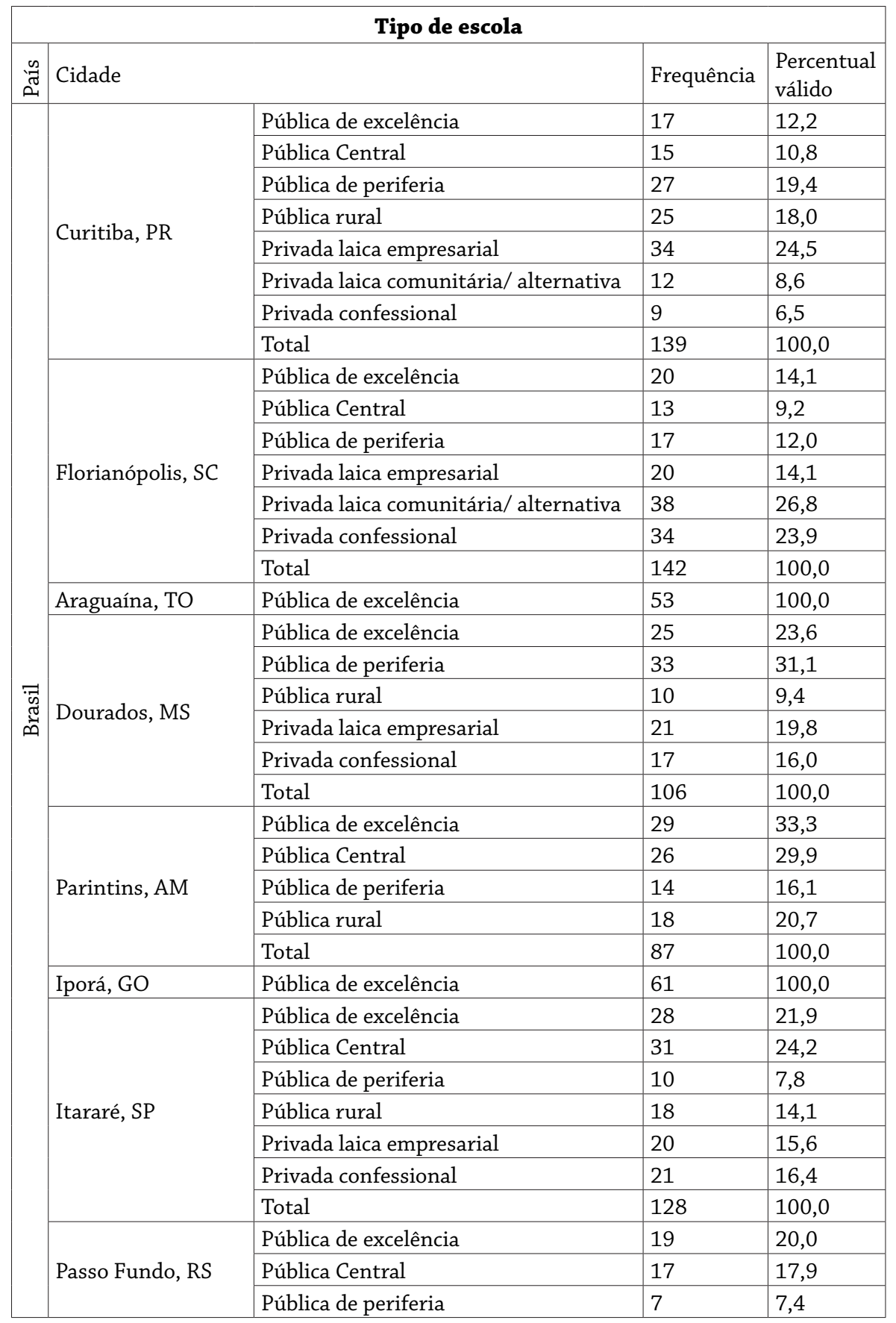


continuação

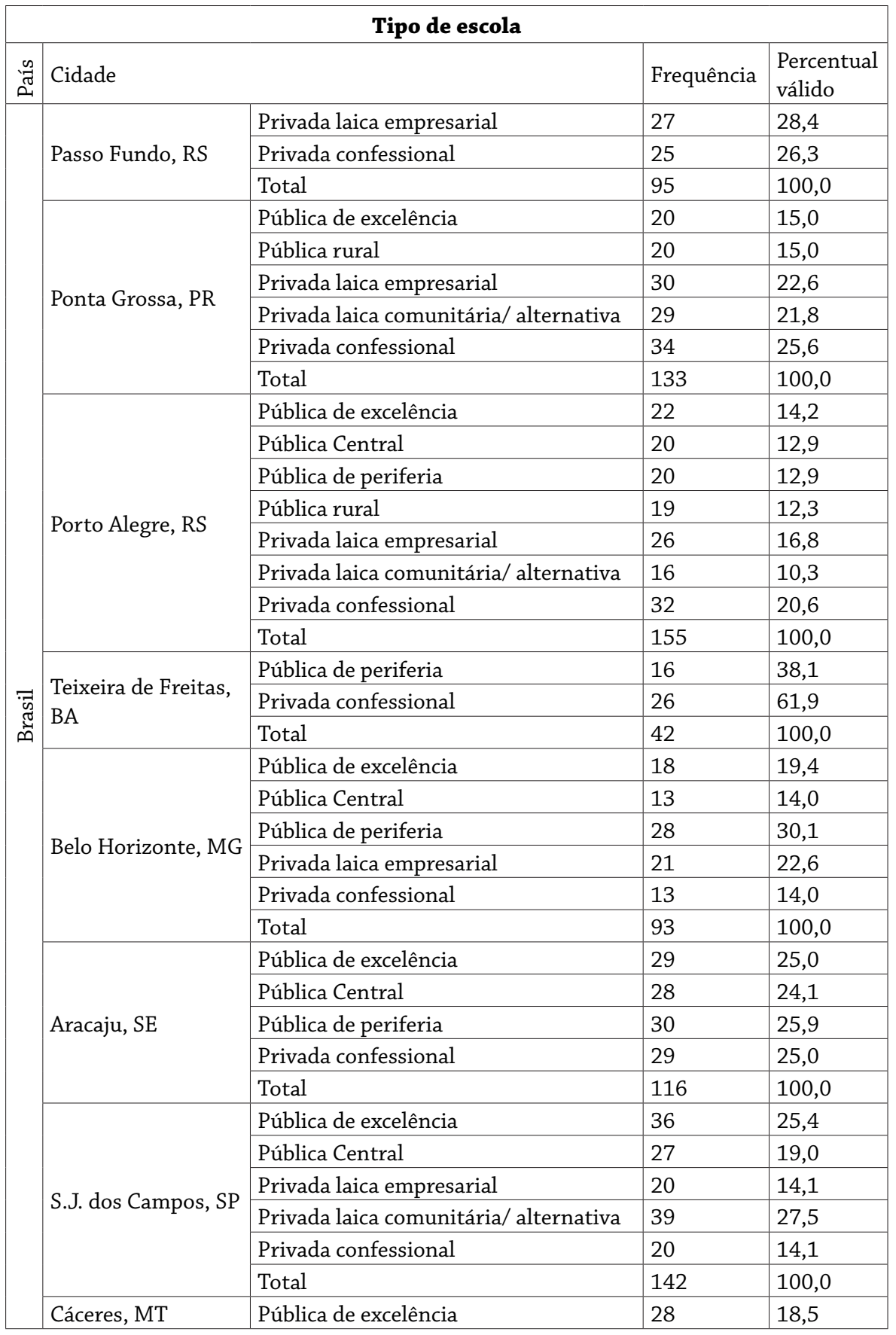


continuação

\begin{tabular}{|c|c|c|c|c|}
\hline \multicolumn{5}{|c|}{ Tipo de escola } \\
\hline ڤే & \multicolumn{2}{|l|}{ Cidade } & \multirow{2}{*}{\begin{tabular}{|l} 
Frequência \\
27
\end{tabular}} & \multirow{2}{*}{\begin{tabular}{|l|}
$\begin{array}{l}\text { Percentua } \\
\text { válido }\end{array}$ \\
17,9
\end{tabular}} \\
\hline & \multirow{7}{*}{ Cáceres, MT } & Pública Central & & \\
\hline & & Pública de periferia & 12 & 7,9 \\
\hline & & Pública rural & 10 & 6,6 \\
\hline & & Privada laica empresarial & 24 & 15,9 \\
\hline & & Privada laica comunitária/ alternativa & 25 & 16,6 \\
\hline & & Privada confessional & 25 & 16,6 \\
\hline & & Total & 151 & 100,0 \\
\hline \multirow{16}{*}{\multicolumn{2}{|c|}{ 䎹 Rondonópolis, MT }} & Pública de excelência & 17 & 12,6 \\
\hline & & Pública Central & 22 & 16,3 \\
\hline & & Pública de periferia & 27 & 20,0 \\
\hline & & Pública rural & 5 & 3,7 \\
\hline & & Privada laica empresarial & 22 & 16,3 \\
\hline & & Privada laica comunitária/ alternativa & 10 & 7,4 \\
\hline & & Privada confessional & 32 & 23,7 \\
\hline & & Total & 135 & 100,0 \\
\hline & & Pública de excelência & 28 & 17,2 \\
\hline & & Pública Central & 29 & 17,8 \\
\hline & & Pública de periferia & 28 & 17,2 \\
\hline & & Pública rural & 19 & 11,7 \\
\hline & & Privada laica empresarial & 22 & 13,5 \\
\hline & & Privada laica comunitária/ alternativa & 10 & 6,1 \\
\hline & & Privada confessional & 27 & 16,6 \\
\hline & & Total & 163 & 100,0 \\
\hline & \multirow{5}{*}{ Três Lagoas, MS } & Pública de excelência & 14 & 20,3 \\
\hline & & Pública de periferia & 28 & 40,6 \\
\hline & & Pública rural & 4 & 5,8 \\
\hline & & Privada confessional & 23 & 33,3 \\
\hline & & Total & 69 & 100,0 \\
\hline & Brasília, DF & Pública de excelência & 98 & 100,0 \\
\hline & \multirow{3}{*}{ Curiúva, PR } & Pública Central & 13 & 50,0 \\
\hline & & Pública rural & 13 & 50,0 \\
\hline & & Total & 26 & 100,0 \\
\hline & \multirow{6}{*}{ Ituiutaba, MG } & Pública de excelência & 32 & 23,5 \\
\hline & & Pública Central & 23 & 16,9 \\
\hline & & Pública de periferia & 27 & 19,9 \\
\hline & & Pública rural & 16 & 11,8 \\
\hline & & Privada laica empresarial & 19 & 14,0 \\
\hline & & Privada confessional & 19 & 14,0 \\
\hline
\end{tabular}


continuação

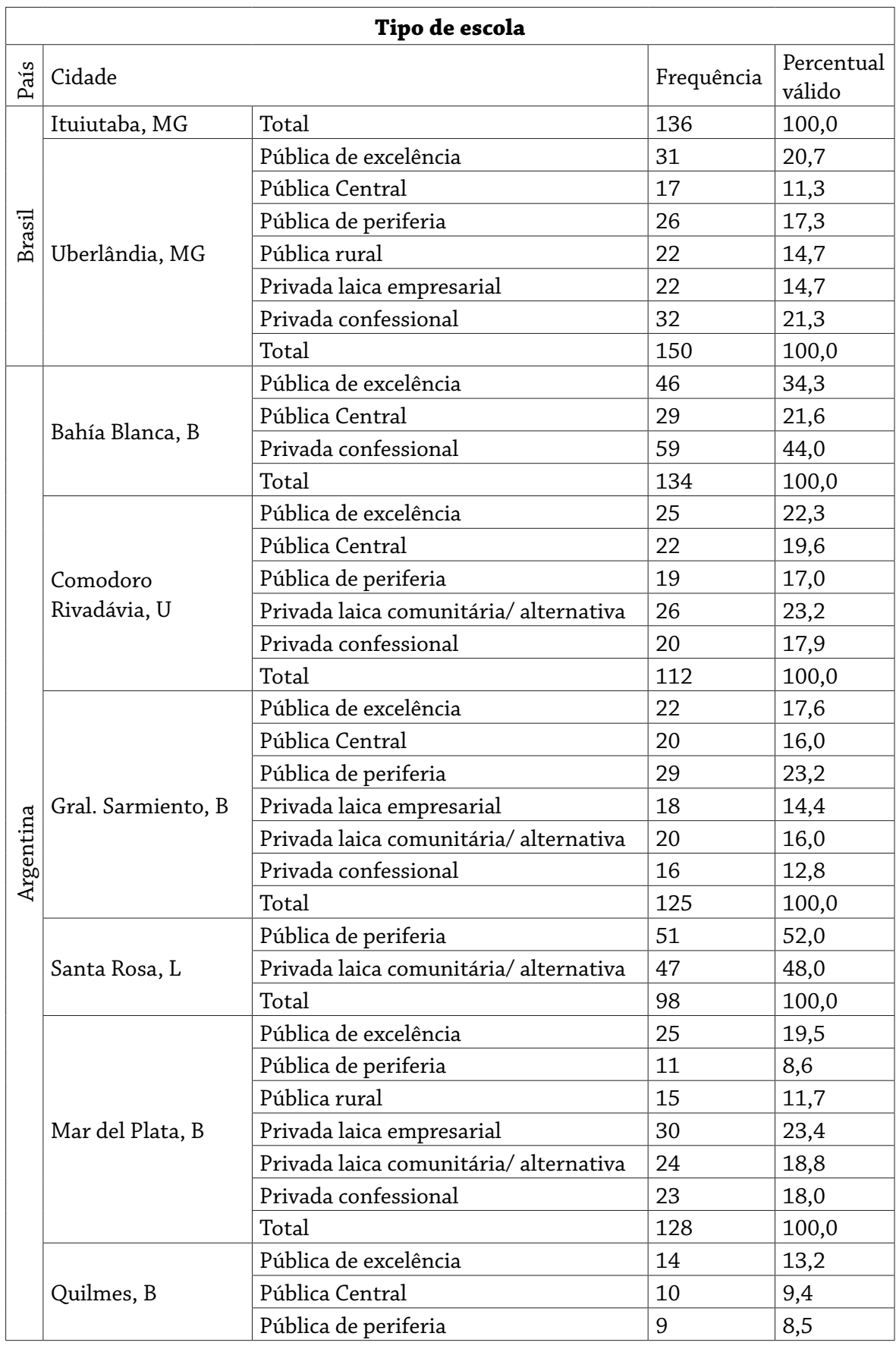


conclusão

\begin{tabular}{|c|c|c|c|c|}
\hline \multicolumn{5}{|c|}{ Tipo de escola } \\
\hline$\stackrel{n}{\pi}$ & \multicolumn{2}{|l|}{ Cidade } & Frequência & $\begin{array}{l}\text { Percentual } \\
\text { válido }\end{array}$ \\
\hline \multirow{17}{*}{ 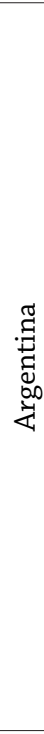 } & \multirow{4}{*}{ Quilmes, B } & Privada laica empresarial & 26 & 24,5 \\
\hline & & Privada laica comunitária/ alternativa & 18 & 17,0 \\
\hline & & Privada confessional & 29 & 27,4 \\
\hline & & Total & 106 & 100,0 \\
\hline & \multirow{6}{*}{ Santa Fe, S } & Pública de excelência & 26 & 20,8 \\
\hline & & Pública Central & 17 & 13,6 \\
\hline & & Pública rural & 26 & 20,8 \\
\hline & & Privada laica comunitária/ alternativa & 26 & 20,8 \\
\hline & & Privada confessional & 30 & 24,0 \\
\hline & & Total & 125 & 100,0 \\
\hline & \multirow{7}{*}{ La Plata, B } & Pública de excelência & 24 & 17,5 \\
\hline & & Pública Central & 24 & 17,5 \\
\hline & & Pública de periferia & 29 & 21,2 \\
\hline & & Pública rural & 17 & 12,4 \\
\hline & & Privada laica empresarial & 17 & 12,4 \\
\hline & & Privada confessional & 26 & 19,0 \\
\hline & & Total & 137 & 100,0 \\
\hline \multirow{5}{*}{ 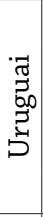 } & \multirow{5}{*}{ Montevidéu } & Pública Central & 48 & 21,1 \\
\hline & & Pública de periferia & 44 & 19,4 \\
\hline & & Pública rural & 16 & 7,0 \\
\hline & & Privada confessional & 119 & 52,4 \\
\hline & & Total & 227 & 100,0 \\
\hline \multirow{10}{*}{ 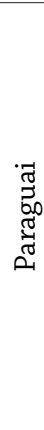 } & \multirow{7}{*}{ Assunção } & Pública de excelência & 5 & 8,9 \\
\hline & & Pública Central & 17 & 30,4 \\
\hline & & Privada laica empresarial & 15 & 26,8 \\
\hline & & Privada confessional & 19 & 33,9 \\
\hline & & Total & 56 & 100,0 \\
\hline & & System & 14 & \\
\hline & & 70 & & \\
\hline & \multirow{3}{*}{ Itá } & Pública rural & 15 & 30,6 \\
\hline & & Privada confessional & 34 & 69,4 \\
\hline & & Total & 49 & 100,0 \\
\hline \multirow{6}{*}{ 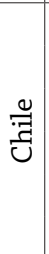 } & \multirow{6}{*}{ Santiago do Chile } & Pública de excelência & 41 & 22,5 \\
\hline & & Pública de periferia & 55 & 30,2 \\
\hline & & Pública rural & 28 & 15,4 \\
\hline & & Privada laica empresarial & 33 & 18,1 \\
\hline & & Privada confessional & 25 & 13,7 \\
\hline & & Total & 182 & 100,0 \\
\hline
\end{tabular}




\section{Professores}

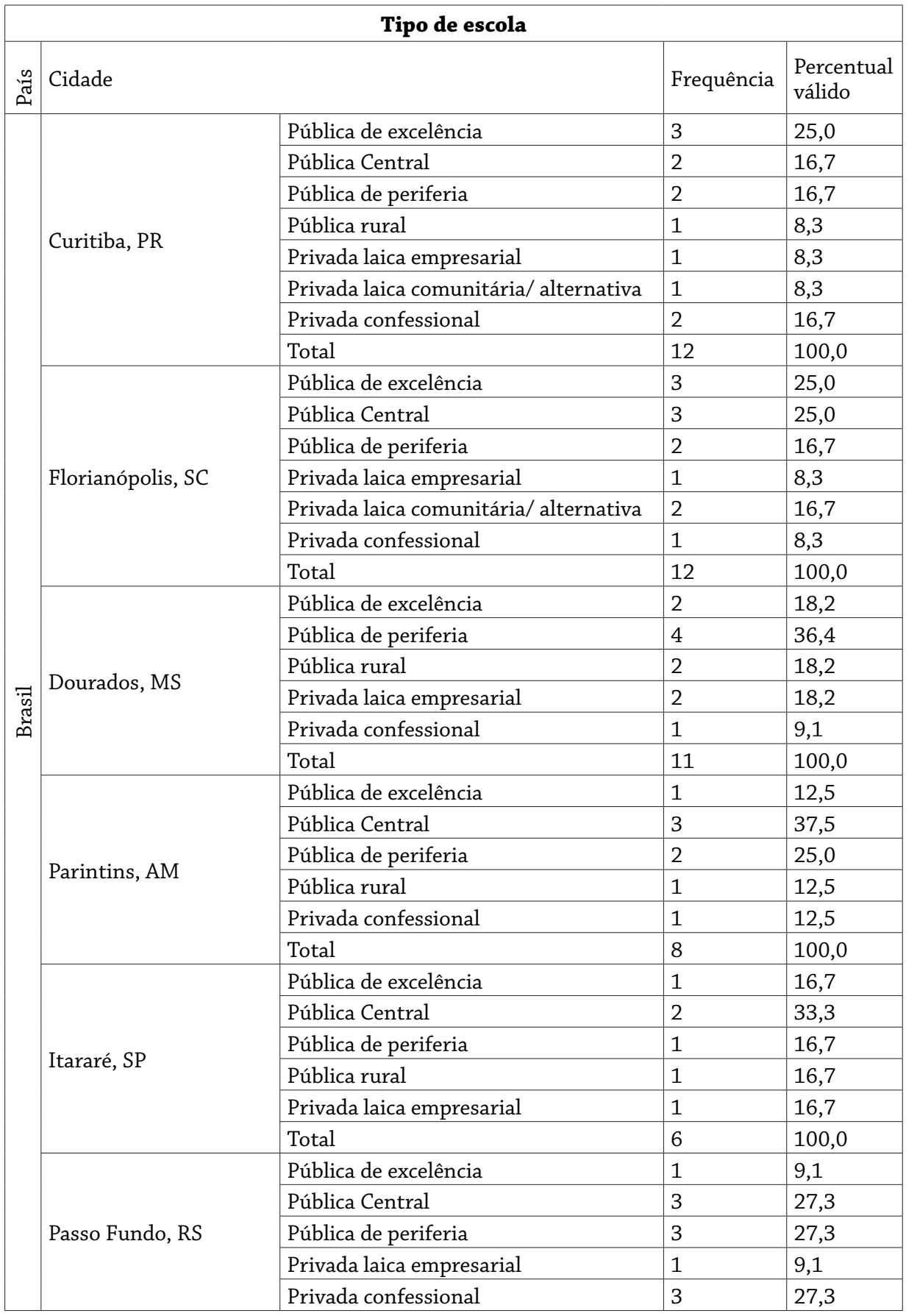


continuação

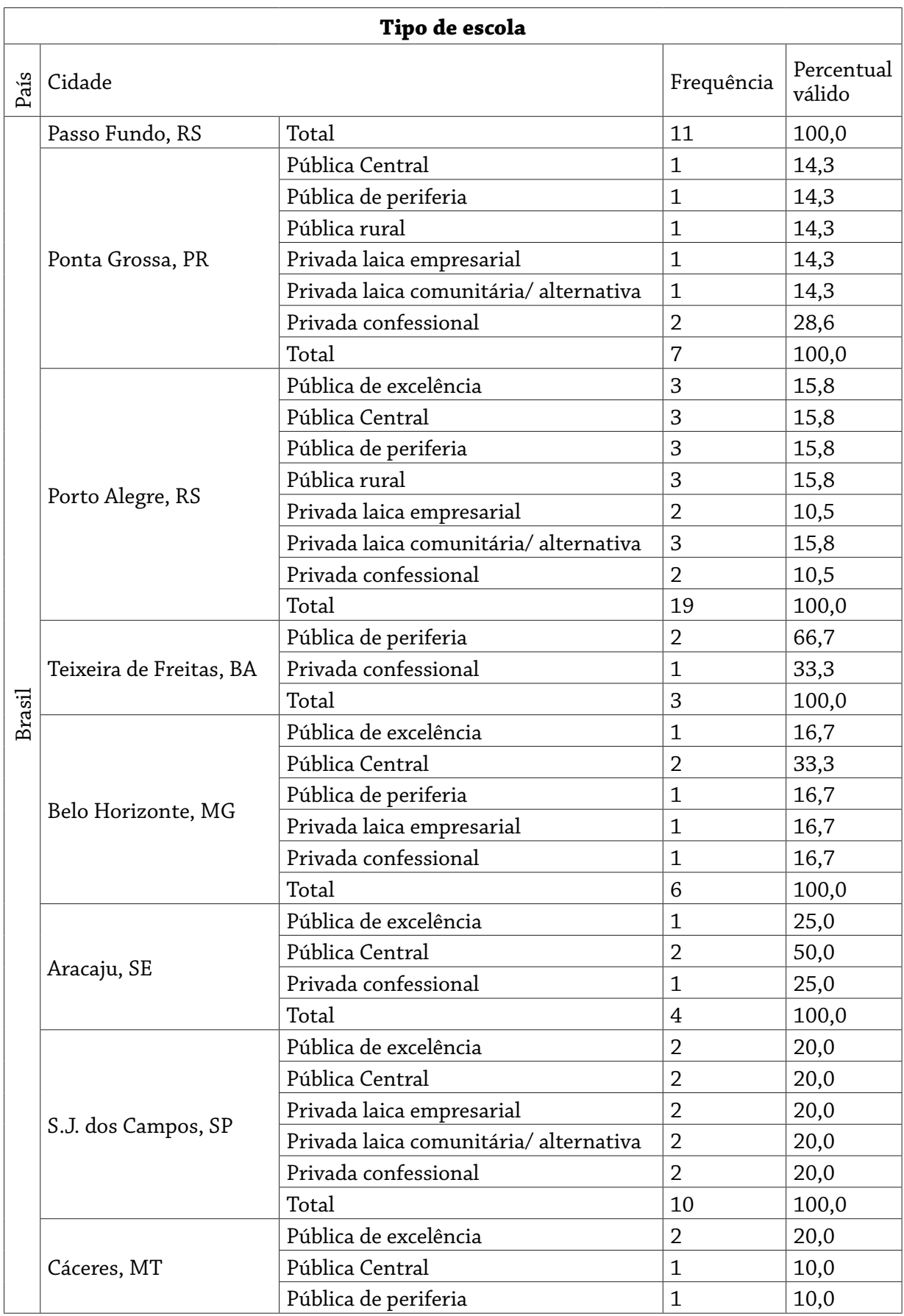


continuação

\begin{tabular}{|c|c|c|c|c|}
\hline \multicolumn{5}{|c|}{ Tipo de escola } \\
\hline مै & \multicolumn{2}{|l|}{ Cidade } & \multirow{2}{*}{\begin{tabular}{|l} 
Frequência \\
1 \\
\end{tabular}} & \multirow{2}{*}{\begin{tabular}{|l} 
Percentual \\
válido
\end{tabular}} \\
\hline & \multirow{5}{*}{ Cáceres, MT } & Pública rural & & \\
\hline & & Privada laica empresarial & 1 & 10,0 \\
\hline & & Privada laica comunitária/ alternativa & 3 & 30,0 \\
\hline & & Privada confessional & 1 & 10,0 \\
\hline & & Total & 10 & 100,0 \\
\hline & \multirow{8}{*}{ Cuiabá, MT } & Pública de excelência & 3 & 25,0 \\
\hline & & Pública Central & 2 & 16,7 \\
\hline & & Pública de periferia & 2 & 16,7 \\
\hline & & Pública rural & 1 & 8,3 \\
\hline & & Privada laica empresarial & 2 & 16,7 \\
\hline & & Privada laica comunitária/ alternativa & 1 & 8,3 \\
\hline & & Privada confessional & 1 & 8,3 \\
\hline & & Total & 12 & 100,0 \\
\hline \multirow{8}{*}{\multicolumn{2}{|c|}{ Rondonópolis, MT }} & Pública de excelência & 3 & 21,4 \\
\hline & & Pública Central & 2 & 14,3 \\
\hline & & Pública de periferia & 3 & 21,4 \\
\hline & & Pública rural & 1 & 7,1 \\
\hline & & Privada laica empresarial & 2 & 14,3 \\
\hline & & Privada laica comunitária/ alternativa & 1 & 7,1 \\
\hline & & Privada confessional & 2 & 14,3 \\
\hline & & Total & 14 & 100,0 \\
\hline & \multirow{3}{*}{ Três Lagoas, MS } & Pública de periferia & 4 & 50,0 \\
\hline & & Privada confessional & 4 & 50,0 \\
\hline & & Total & 8 & 100,0 \\
\hline & Brasília, DF & Pública de excelência & 2 & 100,0 \\
\hline & \multirow{3}{*}{ Curiúva, PR } & Pública Central & 2 & 50,0 \\
\hline & & Pública rural & 2 & 50,0 \\
\hline & & Total & 4 & 100,0 \\
\hline & \multirow{9}{*}{ Ituiutaba, MG } & Pública de excelência & 1 & 14,3 \\
\hline & & Pública Central & 1 & 14,3 \\
\hline & & Pública de periferia & 1 & 14,3 \\
\hline & & Pública rural & 1 & 14,3 \\
\hline & & Privada laica empresarial & 2 & 28,6 \\
\hline & & Privada confessional & 1 & 14,3 \\
\hline & & Total & 7 & 100,0 \\
\hline & & Ausente & 1 & \\
\hline & & Total & 8 & 100,0 \\
\hline & Uberlândia, MG & Pública de excelência & 1 & 12,5 \\
\hline
\end{tabular}


continuação

\begin{tabular}{|c|c|c|c|c|}
\hline \multicolumn{5}{|c|}{ Tipo de escola } \\
\hline שี & \multicolumn{2}{|l|}{ Cidade } & Frequência & $\begin{array}{l}\text { Percentual } \\
\text { válido }\end{array}$ \\
\hline \multirow{6}{*}{ 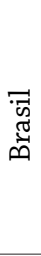 } & \multirow{6}{*}{ Uberlândia, MG } & Pública Central & 3 & 37,5 \\
\hline & & Pública de periferia & 1 & 12,5 \\
\hline & & Pública rural & 1 & 12,5 \\
\hline & & Privada laica empresarial & 1 & 12,5 \\
\hline & & Privada confessional & 1 & 12,5 \\
\hline & & Total & 8 & 100,0 \\
\hline \multirow{32}{*}{ 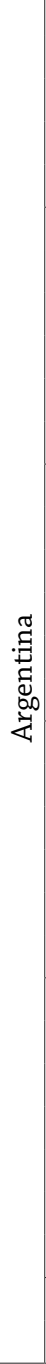 } & \multirow{5}{*}{ Bahía Blanca, B } & Pública de excelência & 2 & 22,2 \\
\hline & & Pública Central & 4 & 44,4 \\
\hline & & Privada laica comunitária/ alternativa & 1 & 11,1 \\
\hline & & Privada confessional & 2 & 22,2 \\
\hline & & Total & 9 & 100,0 \\
\hline & \multirow{6}{*}{ Comodoro Rivadávia, U } & Pública de excelência & 2 & 20,0 \\
\hline & & Pública Central & 2 & 20,0 \\
\hline & & Pública de periferia & 2 & 20,0 \\
\hline & & Privada laica comunitária/ alternativa & 3 & 30,0 \\
\hline & & Privada confessional & 1 & 10,0 \\
\hline & & Total & 10 & 100,0 \\
\hline & \multirow{6}{*}{ Gral. Sarmiento, B } & Pública Central & 1 & 14,3 \\
\hline & & Pública de periferia & 1 & 14,3 \\
\hline & & Privada laica empresarial & 1 & 14,3 \\
\hline & & Privada laica comunitária/ alternativa & 1 & 14,3 \\
\hline & & Privada confessional & 3 & 42,9 \\
\hline & & Total & 7 & 100,0 \\
\hline & \multirow{6}{*}{ Santa Rosa, L } & Pública de excelência & 3 & 23,1 \\
\hline & & Pública de periferia & 3 & 23,1 \\
\hline & & Privada laica empresarial & 1 & 7,7 \\
\hline & & Privada laica comunitária/ alternativa & 3 & 23,1 \\
\hline & & Privada confessional & 3 & 23,1 \\
\hline & & Total & 13 & 100,0 \\
\hline & \multirow{7}{*}{ Mar del Plata, B } & Pública de excelência & 3 & 20,0 \\
\hline & & Pública de periferia & 3 & 20,0 \\
\hline & & Pública rural & 2 & 13,3 \\
\hline & & Privada laica empresarial & 2 & 13,3 \\
\hline & & Privada laica comunitária/ alternativa & 3 & 20,0 \\
\hline & & Privada confessional & 2 & 13,3 \\
\hline & & Total & 15 & 100,0 \\
\hline & \multirow{2}{*}{ Quilmes, B } & Pública de excelência & 3 & 23,1 \\
\hline & & Pública Central & 2 & 15,4 \\
\hline
\end{tabular}


conclusão

\begin{tabular}{|c|c|c|c|c|}
\hline \multicolumn{5}{|c|}{ Tipo de escola } \\
\hline$\stackrel{\mathscr{7}}{\tilde{\sigma}}$ & \multicolumn{2}{|l|}{ Cidade } & Frequência & $\begin{array}{l}\text { Percentual } \\
\text { válido }\end{array}$ \\
\hline \multirow{12}{*}{ 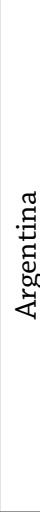 } & \multirow{5}{*}{ Quilmes, B } & Pública de periferia & 3 & 23,1 \\
\hline & & Privada laica empresarial & 2 & 15,4 \\
\hline & & Privada laica comunitária/ alternativa & 2 & 15,4 \\
\hline & & Privada confessional & 1 & 7,7 \\
\hline & & Total & 13 & 100,0 \\
\hline & \multirow{6}{*}{ Santa Fe, S } & Pública de excelência & 3 & 25,0 \\
\hline & & Pública Central & 3 & 25,0 \\
\hline & & Pública de periferia & 1 & 8,3 \\
\hline & & Pública rural & 1 & 8,3 \\
\hline & & Privada confessional & 4 & 33,3 \\
\hline & & Total & 12 & 100,0 \\
\hline & La Plata, B & System & 2 & \\
\hline \multirow{5}{*}{ 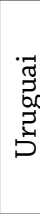 } & \multirow{5}{*}{ Montevidéu } & Pública Central & 48 & 21,1 \\
\hline & & Pública de periferia & 44 & 19,4 \\
\hline & & Pública rural & 16 & 12,5 \\
\hline & & Privada confessional & 119 & 52,4 \\
\hline & & Total & 227 & 100,0 \\
\hline \multirow{8}{*}{$\begin{array}{l}\text { శ్ } \\
\text { ప్ర } \\
\text { శ్ర }\end{array}$} & \multirow{5}{*}{ Assunção } & Pública de excelência & 5 & 8,9 \\
\hline & & Pública Central & 17 & 30,4 \\
\hline & & Privada laica empresarial & 15 & 26,8 \\
\hline & & Privada confessional & 19 & 33,9 \\
\hline & & Total & 56 & 100,0 \\
\hline & \multirow{3}{*}{ Itá } & Pública rural & 15 & 30,6 \\
\hline & & Privada confessional & 34 & 69,4 \\
\hline & & Total & 70 & 100,0 \\
\hline \multirow{7}{*}{ 茪 } & \multirow{7}{*}{ Santiago de Chile } & Pública de excelência & 2 & 13,3 \\
\hline & & Pública de periferia & 5 & 33,3 \\
\hline & & Pública rural & 2 & 13,3 \\
\hline & & Privada laica empresarial & 2 & 13,3 \\
\hline & & Privada laica comunitária/ alternativa & 1 & 6,7 \\
\hline & & Privada confessional & 3 & 20,0 \\
\hline & & Total & 15 & 100,0 \\
\hline
\end{tabular}


2. Professores

\begin{tabular}{|c|c|c|c|c|c|}
\hline صี & \multicolumn{3}{|l|}{ Cidade } & \multirow{2}{*}{$\begin{array}{l}\text { Frequência } \\
3 \\
\end{array}$} & \multirow{2}{*}{\begin{tabular}{|l|}
$\begin{array}{l}\text { Percentual } \\
\text { válido }\end{array}$ \\
25,0 \\
\end{tabular}} \\
\hline & \multirow{8}{*}{ Curitiba, PR } & \multirow{8}{*}{ Válidos } & Pública de excelência & & \\
\hline & & & Pública Central & 2 & 16,7 \\
\hline & & & Pública de periferia & 2 & 16,7 \\
\hline & & & Pública rural & 1 & 8,3 \\
\hline & & & Privada laica empresarial & 1 & 8,3 \\
\hline & & & $\begin{array}{l}\text { Privada laica comunitária/ } \\
\text { alternativa }\end{array}$ & 1 & 8,3 \\
\hline & & & Privada confessional & 2 & 16,7 \\
\hline & & & Total & 12 & 100,0 \\
\hline & \multirow{7}{*}{ Florianópolis, SC } & \multirow{7}{*}{ Válidos } & Pública de excelência & 3 & 25,0 \\
\hline & & & Pública Central & 3 & 25,0 \\
\hline & & & Pública de periferia & 2 & 16,7 \\
\hline & & & Privada laica empresarial & 1 & 8,3 \\
\hline & & & $\begin{array}{l}\text { Privada laica comunitária/ } \\
\text { alternativa }\end{array}$ & 2 & 16,7 \\
\hline & & & Privada confessional & 1 & 8,3 \\
\hline & & & Total & 12 & 100,0 \\
\hline \multirow{6}{*}{\multicolumn{2}{|c|}{ ت্ত్⿹ }} & \multirow{6}{*}{ Válidos } & Pública de excelência & 2 & 18,2 \\
\hline & & & Pública de periferia & 4 & 36,4 \\
\hline & & & Pública rural & 2 & 18,2 \\
\hline & & & Privada laica empresarial & 2 & 18,2 \\
\hline & & & Privada confessional & 1 & 9,1 \\
\hline & & & Total & 11 & 100,0 \\
\hline \multirow{6}{*}{\multicolumn{2}{|c|}{ Parintins, AM }} & \multirow{6}{*}{ Válidos } & Pública de excelência & 1 & 12,5 \\
\hline & & & Pública Central & 3 & 37,5 \\
\hline & & & Pública de periferia & 2 & 25,0 \\
\hline & & & Pública rural & 1 & 12,5 \\
\hline & & & Privada confessional & 1 & 12,5 \\
\hline & & & Total & 8 & 100,0 \\
\hline & \multirow{6}{*}{ Itararé, SP } & \multirow{6}{*}{ Válidos } & Pública de excelência & 1 & 16,7 \\
\hline & & & Pública Central & 2 & 33,3 \\
\hline & & & Pública de periferia & 1 & 16,7 \\
\hline & & & Pública rural & 1 & 16,7 \\
\hline & & & Privada laica empresarial & 1 & 16,7 \\
\hline & & & Total & 6 & 100,0 \\
\hline & \multirow{5}{*}{ Passo Fundo, RS } & \multirow{5}{*}{ Válidos } & Pública de excelência & 1 & 9,1 \\
\hline & & & Pública Central & 3 & 27,3 \\
\hline & & & Pública de periferia & 3 & 27,3 \\
\hline & & & Privada laica empresarial & 1 & 9,1 \\
\hline & & & Privada confessional & 3 & 27,3 \\
\hline
\end{tabular}


continuação

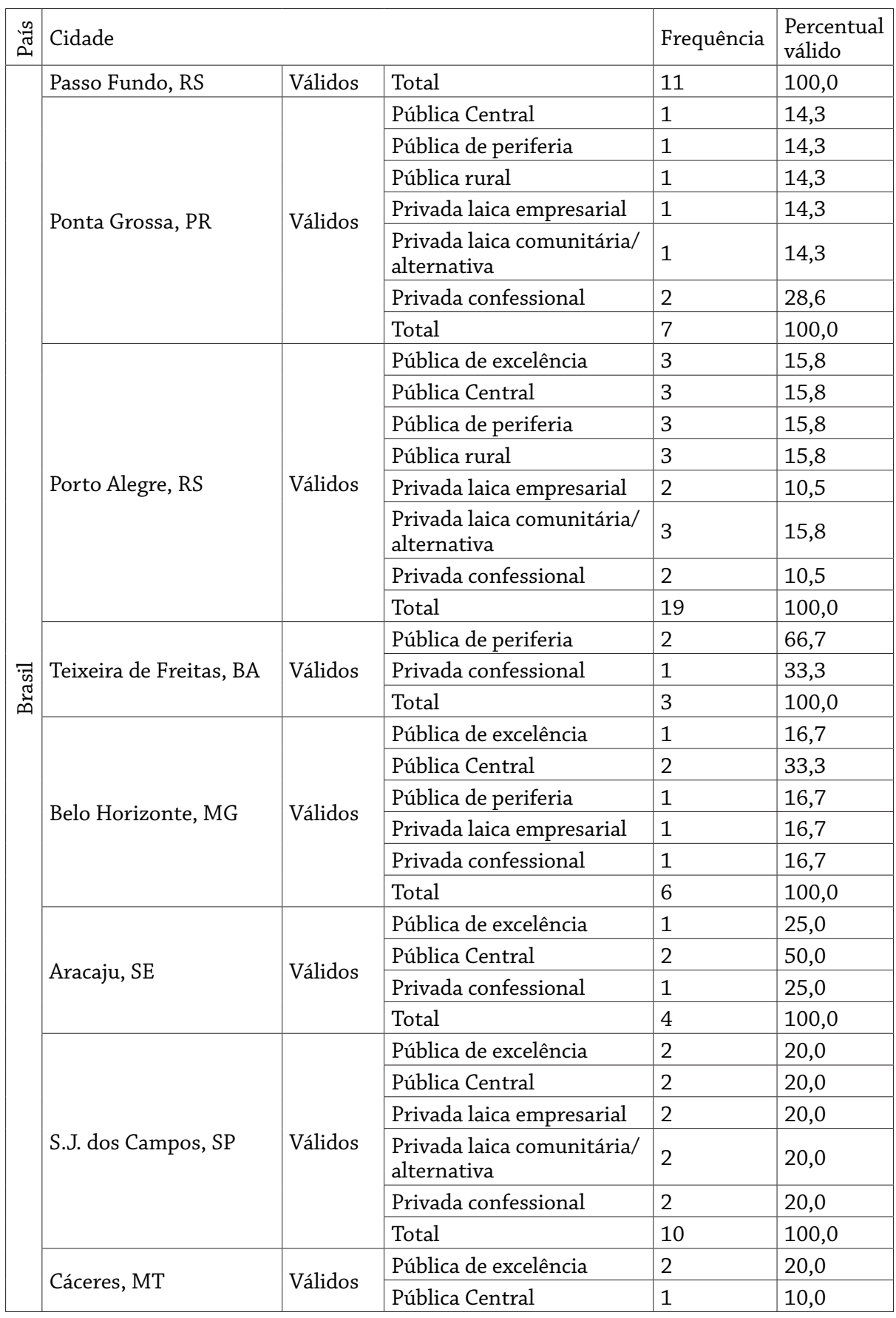


continuação

\begin{tabular}{|c|c|c|c|c|c|}
\hline$\ddot{\pi}$ & \multicolumn{3}{|l|}{ Cidade } & \multirow{2}{*}{$\begin{array}{l}\text { Frequência } \\
1 \\
\end{array}$} & \multirow{2}{*}{\begin{tabular}{|l|}
$\begin{array}{l}\text { Percentual } \\
\text { válido }\end{array}$ \\
10,0 \\
\end{tabular}} \\
\hline & \multirow{6}{*}{ Cáceres, MT } & \multirow{6}{*}{ Válidos } & Pública de periferia & & \\
\hline & & & Pública rural & 1 & 10,0 \\
\hline & & & Privada laica empresarial & 1 & 10,0 \\
\hline & & & $\begin{array}{l}\text { Privada laica comunitária/ } \\
\text { alternativa }\end{array}$ & 3 & 30,0 \\
\hline & & & Privada confessional & 1 & 10,0 \\
\hline & & & Total & 10 & 100,0 \\
\hline & \multirow{8}{*}{ Cuiabá, MT } & \multirow{8}{*}{ Válidos } & Pública de excelência & 3 & 25,0 \\
\hline & & & Pública Central & 2 & 16,7 \\
\hline & & & Pública de periferia & 2 & 16,7 \\
\hline & & & Pública rural & 1 & 8,3 \\
\hline & & & Privada laica empresarial & 2 & 16,7 \\
\hline & & & $\begin{array}{l}\text { Privada laica comunitária/ } \\
\text { alternativa }\end{array}$ & 1 & 8,3 \\
\hline & & & Privada confessional & 1 & 8,3 \\
\hline & & & Total & 12 & 100,0 \\
\hline \multirow{8}{*}{\multicolumn{2}{|c|}{ 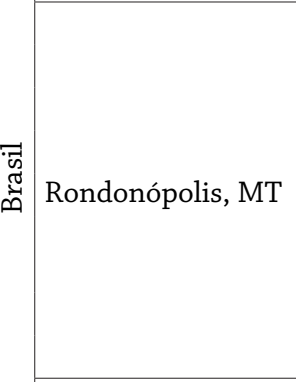 }} & \multirow{8}{*}{ Válidos } & Pública de excelência & 3 & 21,4 \\
\hline & & & Pública Central & 2 & 14,3 \\
\hline & & & Pública de periferia & 3 & 21,4 \\
\hline & & & Pública rural & 1 & 7,1 \\
\hline & & & Privada laica empresarial & 2 & 14,3 \\
\hline & & & $\begin{array}{l}\text { Privada laica comunitária/ } \\
\text { alternativa }\end{array}$ & 1 & 7,1 \\
\hline & & & Privada confessional & 2 & 14,3 \\
\hline & & & Total & 14 & 100,0 \\
\hline \multirow{3}{*}{\multicolumn{2}{|c|}{ Três Lagoas, MS }} & \multirow{3}{*}{ Válidos } & Pública de periferia & 4 & 50,0 \\
\hline & & & Privada confessional & 4 & 50,0 \\
\hline & & & Total & 8 & 100,0 \\
\hline & Brasília, DF & Válidos & Pública de excelência & 2 & 100,0 \\
\hline & \multirow{3}{*}{ Curiúva, PR } & \multirow{3}{*}{ Válidos } & Pública Central & 2 & 50,0 \\
\hline & & & Pública rural & 2 & 50,0 \\
\hline & & & Total & 4 & 100,0 \\
\hline & \multirow{8}{*}{ Ituiutaba, MG } & \multirow{7}{*}{ Válidos } & Pública de excelência & 1 & 14,3 \\
\hline & & & Pública Central & 1 & 14,3 \\
\hline & & & Pública de periferia & 1 & 14,3 \\
\hline & & & Pública rural & 1 & 14,3 \\
\hline & & & Privada laica empresarial & 2 & 28,6 \\
\hline & & & Privada confessional & 1 & 14,3 \\
\hline & & & Total & 7 & 100,0 \\
\hline & & Ausente & & 1 & \\
\hline
\end{tabular}


continuação

\begin{tabular}{|c|c|c|c|c|c|}
\hline \multirow[t]{9}{*}{$\frac{\pi}{\tilde{\pi}}$} & \multicolumn{3}{|l|}{ Cidade } & \multirow{3}{*}{\begin{tabular}{|l|} 
Frequência \\
8 \\
1 \\
\end{tabular}} & \multirow{3}{*}{$\begin{array}{l}\text { Percentual } \\
\text { válido }\end{array}$} \\
\hline & Ituiutaba, MG & \multicolumn{2}{|l|}{ Total } & & \\
\hline & \multirow{7}{*}{ Uberlândia, MG } & \multirow{7}{*}{ Válidos } & Pública de excelência & & \\
\hline & & & Pública Central & 3 & 37,5 \\
\hline & & & Pública de periferia & 1 & 12,5 \\
\hline & & & Pública rural & 1 & 12,5 \\
\hline & & & Privada laica empresarial & 1 & 12,5 \\
\hline & & & Privada confessional & 1 & 12,5 \\
\hline & & & Total & 8 & 100,0 \\
\hline & \multirow{5}{*}{ Bahía Blanca, B } & \multirow{5}{*}{ Válidos } & Pública de excelência & 2 & 22,2 \\
\hline & & & Pública Central & 4 & 44,4 \\
\hline & & & $\begin{array}{l}\text { Privada laica comunitária/ } \\
\text { alternativa }\end{array}$ & 1 & 11,1 \\
\hline & & & Privada confessional & 2 & 22,2 \\
\hline & & & Total & 9 & 100,0 \\
\hline \multirow{12}{*}{\multicolumn{2}{|c|}{ Gral. Sarmiento, B }} & \multirow{6}{*}{ Válidos } & Pública de excelência & 2 & 20,0 \\
\hline & & & Pública Central & 2 & 20,0 \\
\hline & & & Pública de periferia & 2 & 20,0 \\
\hline & & & $\begin{array}{l}\text { Privada laica comunitária/ } \\
\text { alternativa }\end{array}$ & 3 & 30,0 \\
\hline & & & Privada confessional & 1 & 10,0 \\
\hline & & & Total & 10 & 100,0 \\
\hline & & \multirow{6}{*}{ Válidos } & Pública Central & 1 & 14,3 \\
\hline & & & Pública de periferia & 1 & 14,3 \\
\hline & & & Privada laica empresarial & 1 & 14,3 \\
\hline & & & $\begin{array}{l}\text { Privada laica comunitária/ } \\
\text { alternativa }\end{array}$ & 1 & 14,3 \\
\hline & & & Privada confessional & 3 & 42,9 \\
\hline & & & Total & 7 & 100,0 \\
\hline & \multirow{6}{*}{ Santa Rosa, L } & \multirow{6}{*}{ Válidos } & Pública de excelência & 3 & 23,1 \\
\hline & & & Pública de periferia & 3 & 23,1 \\
\hline & & & Privada laica empresarial & 1 & 7,7 \\
\hline & & & $\begin{array}{l}\text { Privada laica comunitária/ } \\
\text { alternativa }\end{array}$ & 3 & 23,1 \\
\hline & & & Privada confessional & 3 & 23,1 \\
\hline & & & Total & 13 & 100,0 \\
\hline \multirow{5}{*}{\multicolumn{2}{|c|}{ Mar del Plata, B }} & \multirow{5}{*}{ Válidos } & Pública de excelência & 3 & 20,0 \\
\hline & & & Pública de periferia & 3 & 20,0 \\
\hline & & & Pública rural & 2 & 13,3 \\
\hline & & & Privada laica empresarial & 2 & 13,3 \\
\hline & & & $\begin{array}{l}\text { Privada laica comunitária/ } \\
\text { alternativa }\end{array}$ & 3 & 20,0 \\
\hline
\end{tabular}


conclusão

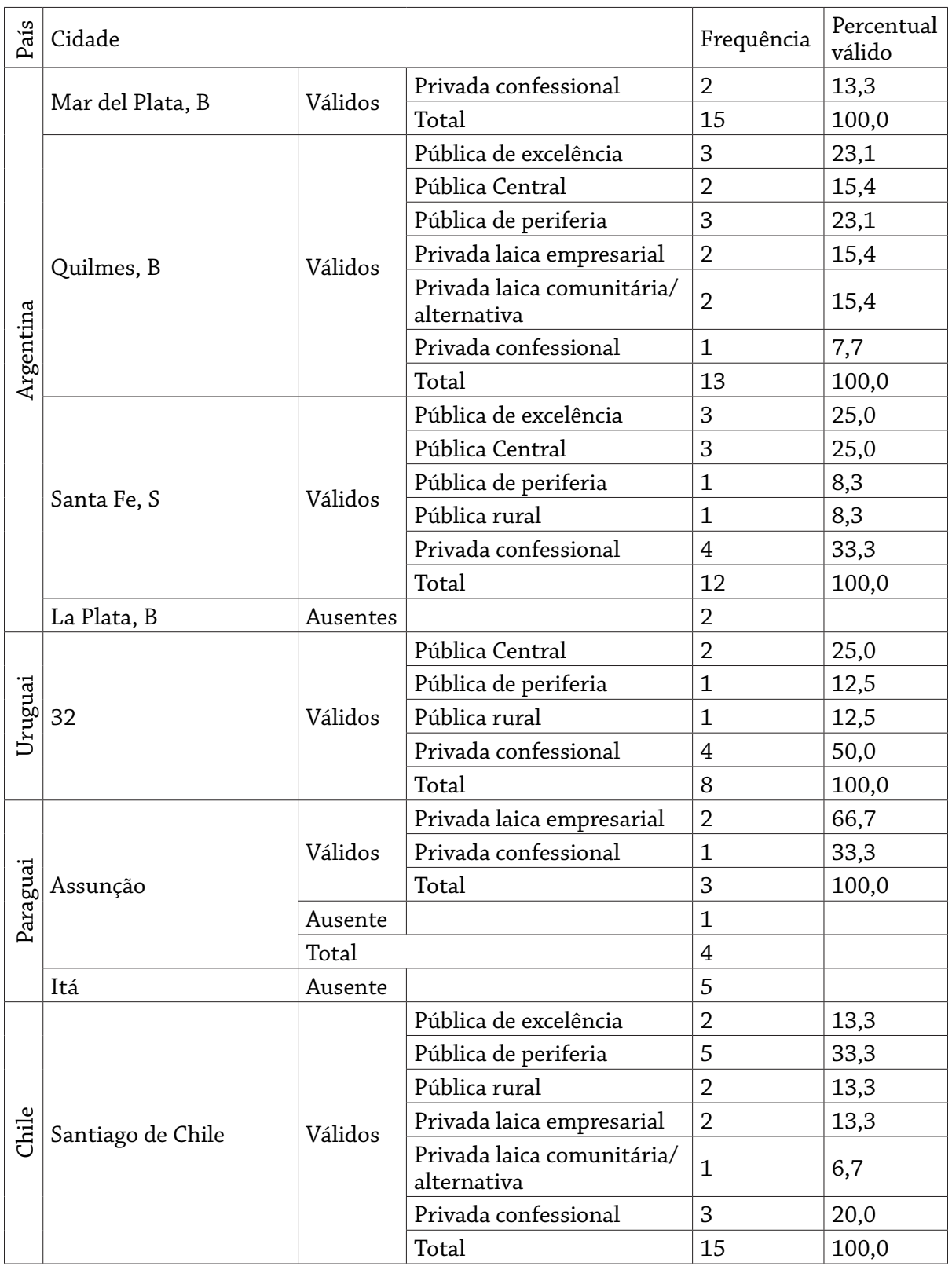


APÊNDICE B - QUESTIONÁRIOS 
Escola: $\mathrm{T} \square \mathrm{N}^{0} \cdot \square$

Os jovens e a História - Brasil

1. Sua turma foi escolhida para particípar de uma investígação envolvendo alunos de vâríos paises da Améríca do Sul.

2. Através desse questionário desejamos saber como os jovens vêem a história e conhecer algumas de suas opiniôes sobre o presente e of futuro.

3. Durante o preenchimento do questionário, não se preocupe com as respostas dos seus vizinhos de carteira. Concentre-se nas SUAS opiniôes e não na maneira como os outros acham que você devería responder.

4. Algumas perguntas seräo mais fáceis para você e mais dificeis para os outros. Não há resposta certa ou errada, por isso responda sinceramente. Se você não souber responder alguma questâo, deike-a em branco e passe às questőes seguintes.

5. Se alguma pergunta não estiver clara para vocẽ peça ajuda ao coordenador da atividade, mas de maneira que não desconcentre seus colegas.

6. O professor nâo terá conhecimento das suas respostas, e suas informaçốes se râo tratadas confidencialmente em todas as etapas desta pesquisa.

Muito obrigado por sua valiosa partícipação nesse projeto!

Prof. Dr. L. F. Cerri - UEPG - Coordenador do projeto no Brasil

Idade: $\_$Sexo: $\square$ Masculino $\square$ Feminino

1. O QUE SIGNIFICA A HISTÓRIA PARA VOCÊ?

a. Uma matéria da escola e nada mais

b. Uma fonte de coisas interessantes que estimula minha imaginaçã̃o

c. Uma possibilidade para aprender com os erros e acertos dos outros

d. Algo que já morreu e passou e que nẫo tem nada a ver com a minha vida

e. Um número de exemplos que ensinam

oque é certo e o que é errado, o que é bom e oque é mau

f. Mostra o que está por trás da maneira de viver no presente e explica os problemas atuais

G. Um amontoado de crueldades e desgraças

h. Uma forma de entender a minha vida

como parte das mudanças na história

2. QUAIS AS FORMAS EM QUE A HISTÓRIA APARECE QUE MAIS TE AGRADAM?

a. Livros escolares

b. Documentos e outros vestígios

c. Romances históricos

d. Filmes

e. Novelas e minisséries

f. Documentários na televisão

g. Falas dos professores

h. Falas de outros adultos (pais, avós)

i. Museus e lugares históricos

3. QUAIS AS FORMAS EM QUE A HISTÓRIA APARECE EM QUE VOCÊ MAIS CONFIA?

a. Livros escolares

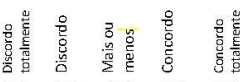

$\square \square \square \square \square$

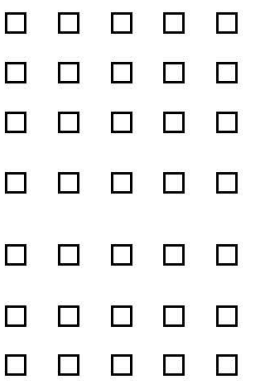

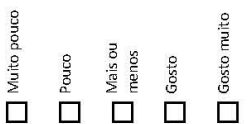

$\square \square \square-\square \square$

$\square \square \square \square \square$

$\square \square \square \square \square$

$\square \square \square \square \square$

$\square \square \square \square \square$

$\square \square \square \square \square$

$\square \square \square \square \square$

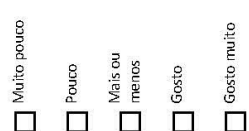

b. Documentos e outros vestígios $\square \quad \square \quad \square \quad \square \quad \square$

c. Romances históricos

d. Filmes

e. Novelas e minisséries

f. Documentários na televisão

g. Falas dos professores

h. Falas de outros adultos \{pais, avós\}

i. Museus e lugares históricos
4. EM SUA OPINIÃO, QUAL A IMPORTÂNCIA DE CADA UM DOS SEGUINTES OBJETIVOS AO SE ESTUDAR A HISTÓRIA:

a. Conhecer o passado

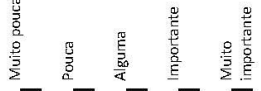
$\square \square \square \square \square$

b. Compreender o presente

c. Buscar orientação para of futuro

5. O QUE NORMALMENTE ACONTECE EM DURANTE AS AULAS DE HISTÓRIA?

a. Ouvimos as exposições dos professores sobre o passado

b. Somos informados do que foi bom ou mau, certo ou errado na História

c. Discutimos diferentes explicaçôes sobre o que aconteceu no passado

d. Pesquisamos diversas fontes históricas: documentos, fotografias, figuras, mapas

e. Nós mesmos recordamose reinterpretamos a História

f. Ouvimos fitas, $C D$ s ou vernos filmes e videos sobre História

g. Usamos livros escolares, apostilas ou algum outro material (xerox)

h. Fazemos trabalhos de grupo, teatro, visitas a museus, projetos com a comunidade

\section{EM QUE SUAS AULAS DE HISTÓRIA \\ MAIS SE CONCENTRAM?}

a. Procuramos conhecer os principais fatos da história

b. Julgamos os principais acontecimentos da história a partir do ponto de vista dos direitos humanos

c. Tentamos entender como era a vida no passado levando em conta todos os pontos de vista

d. Tentamos compreender o comportamento das pessoas do passado levando em conta o pensamento deles na época em que viveram

e. Usamos a História para entender a situação do mundo atual e descobrir as tendências de mudança

f. Estudamos de forma que seja interessante e incentive nossa imaginação

g. Aprendemos as tradiçôes caracteristicas, valores e a missão da nossa nação e de nossa sociedade

h. Aprendemos a valorizar os vestígios históricos e as construções antigas

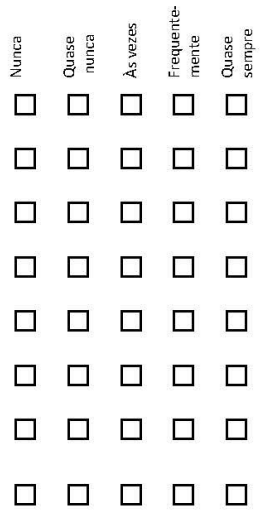

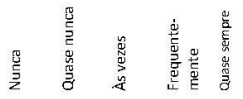

$\square \square \square \square$

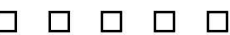

$\square \square \square$
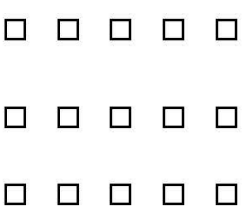

$\square \square \square \square \square$

$\square \square \square \square \square$ 
7. Qual é a sua religião? (marcar uma alternativa)
a. $\square$ Católica
b. $\square$ Evangé lica
d. $\square$ Islâmica
D.
e. $\square$ outra
f. $\square$ Nenhuma

$\begin{aligned} & \text { 8. O que a religião } \\ & \text { representa para você? }\end{aligned}$
$\begin{aligned} & \text { 9. Qual seu interesse pela } \\ & \text { politica? }\end{aligned}$

11. Qual é a ocupação do membro da familia que recebe o maior pagamento? (marque apenas uma opção, escolha a ocupação mais próxima)

\begin{tabular}{|c|c|}
\hline a) Diretor de empresa & $\begin{array}{l}\text { f) Trabalhador na agricultura/ } \\
\text { pecuária/pesca }\end{array}$ \\
\hline b) Profissão de nivel superior & $\begin{array}{l}\text { g) Operário da indústria ou } \\
\text { construção }\end{array}$ \\
\hline $\begin{array}{l}\text { c) Técnico/ profissão de níve } \\
\text { médio }\end{array}$ & $\begin{array}{l}\text { h) Operador de máquinas/ } \\
\text { motorista }\end{array}$ \\
\hline d) Funcionário de escritório & i) Trabalhador näo-qualificado \\
\hline $\begin{array}{l}\text { e) Trabalhador no comércio/ } \\
\text { mercados }\end{array}$ & j) Militar/policial \\
\hline
\end{tabular}

12. Fazendo um levantamento rápido, quantos livros existem em sua casa, fora os livros didáticos e revistas?

$\begin{array}{lll}\square \text { nenhum } & \square \text { até } 10 & \square \text { 10 a } 50 \\ \square \text { a a } 100 & \square \text { mais de } 100 & \end{array}$

13a. Qual o grau de escolaridade do seu pai?

$\square$ a. nenhuma escolaridade

$\square$ h. ensino médio incompleto

$\square$ b. primário incompleto

$\square_{\mathrm{g} \text {. ensino médio completo }}$

$\square$ c. primário completo

$\square$ h. curso profissionalizante

$\square$ d. fundamental incompleto

$\square$ i. ens. superior incompleto

$\square$ e.fundamental completo

$\square$ j. ens. superior completo

13b. Qual o grau de escolaridade da sua mãe?

$\square$ a. nenhuma escolaridade

$\square$ h. ensino médio incompleto

$\square$ b. primário incompleto

$\square$ g. ensino médio completo

$\square$ c. primário completo

$\square$ h. curso profissionalizante

$\square$ d. fundamental incompleto

$\square$ i. ens. superior incompleto

$\square$ e.fundamental completo

$\square$ j. ens. superior completo

14. Todos sabem que é dificil prever o futuro, mas qual o grau de ensino que vocë gostaria de atingir? (marcar uma alternativa)

$\square$ a. Terminar o Ensino Médio e entrar no mercado de trabalho

$\square$ b. Cursar uma universidade / curso superior

15. Coloque cada resposta segundo a ordem que aconteceram na história da América marcando desde 1 para mais antigo 1 até 5 para o mais recente. Não deixe de usar os números 2,3 e 4 !

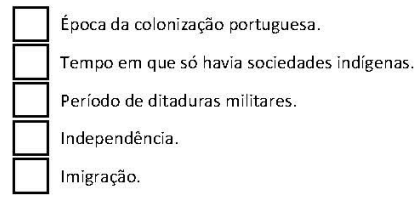

16. QUAL SEU INTERESSE PELO SEGUINTE PERÍODO DA HISTÓRIA:

a. A origem dos seres humanos

b. Mundo Antigo

c. Idade Média (aproxim. de 500 a 1500)

d. O período entre 1500 e 1800

e. O período de 1800 a 1945

f. De 1945 até os dias de hoje

17. Qual seu interesse pelos seguintes temas da história:

a. A vida cotidiana das pessoas comuns

b. Reis, presidentes e personagens

politicamente importantes no pode

c. Aventureiros e grandes descobridores

d. Guerras e ditaduras

e. Culturas de países distantes

f. A formação das naçôes

g. O desenvolvimento da democracia

h. A interferência do homem no meio ambiente

O desenvolvimento da agricultura, da indústria e do comérci

j. A história de assuntos específicos (por exemplo: a história dos carros, da Igreja da música, etc.

k. A história da sua familia

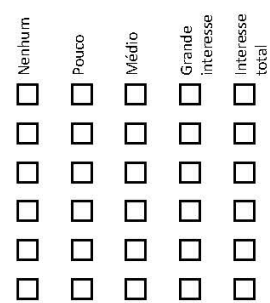

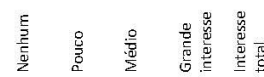

$\square \square \square \square \square \square$

$\square \square \square \square \square$
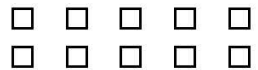

$\square \square \square \square \square$
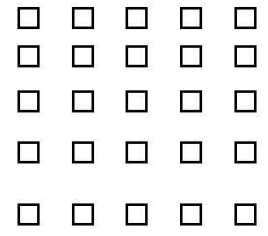

. A historia da sua familit

18. Qual seu interesse sobre a história dos seguintes lugares:

a. A história da localídade onde vivo
b. A história da minha regiâa
b. A história da minha regiâo
c. A histórīa do Brasil

d. Outros países da América Latina

e. A história do mundo, excluindo a América Latina

19. Que influência você acha que tiveram os 19. Que influencia vote achá que tiveram os
seguintes fatores na mudança da vida das
pessoas desde 1970 até hoje?

a. Invençôes técnicas e mecanização

b. Movimentos e conflitos sociais

c. Reis, presidentes e personagens politicamente importantes no poder

d. Reformas politicas $\square \square \square \square \square$ $\square$

e. Fundadores de religiöes e chefes religiosos

f. Desenvolvimento da ciência e do conhecimento $\square \square \square \square \square$

g. Guerrase conflitos $\square \square \square \square \square$

h. Interesses econômi cos e concorrência econômica $\square \square \square \square \square$

. Filósofos, pensadores e pessoas instruidas $\square \square \square \square \square \square$ j. Revoluçôes políticas $\square \square \square \square \square$ k. Problemas ambientais $\square \square \square \square \square$ I. Migrações $\square \square \square \square \square$ m. Organizaçấo dos trabalhadores $\square \square \square \square \square$ n. Esforço pessoal $\square \square \square \square \square$ o. Cientistas e engenheiros $\square \square \square \square \square$ 
20. Que influência você acha que terăo os seguintes fatores na mudança da vida da pessoas de agora até $\mathbf{2 . 0 5 0}$ ? a. Invenções técnicas e mecanizaçăo

\section{童}

b. Movimentos e conflitos sociais

c. Reis, presidentes e personagens politicamente importantes no poder d. Reformas politicas

e. Fundadores de religiőes e chefes religiosos

f. Desenvolvimento da ciência e do conhecimento

g. Guerras e conflitos

h. Interesses econômicos e concorrência econômica

i. Filósofos, pensadores e pessoas instruidas

j. Revoluçōes politicas

k. Problemas ambientais

I. Migraçōes

m. Organização dos trabalhadores

n. Esforço pessoal

o. Cientistas e engenheiros

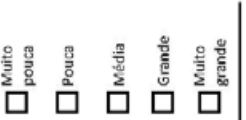

$\square \square \square \square \square$ $\square \square \square \square \square$ 맘ㅁ ㅁㅁ $\square$ ㅁㅁㅁ 마 $\square$ 무마 마 맘ㅁ ㅁㅁ 마마 ㅁㅁㅁ $\square \square \square \square \square$

$\square \square \square \square \square$

24. Que imagem você associa a Adolf Hitler?

a. Um ditador cínico e agressor culpado de

matança em massa

b. O principal opositor ao comunismo

c. Alguém que foi usado pelos industriais alemães e imperialistas

d. Um grande orador, organizador e comandante

e. Um doente mental e criminoso antisocial

f. Um criador de ordem, segurança integraçăo nacional

g. Um lutador contra a mestiçagem cultural e a infiltraç̧o estrangeira

h. O representante mais conhecido do poder totalitário e violento

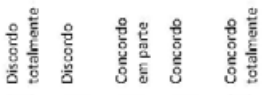

$\square \square \square \square \square$

$\square \square \square \square \square$

पव $\square \square$

$\square \square \square \square \square$

ㅁㅁ

ㅁ $\square$ व

ㅁㅁ $\square$

ㅁ $\square \square \square$

25. Que importância tem para você o seguinte:

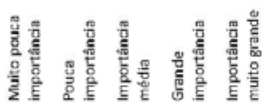

a. Familia $\square \square \square \square \square$

b. Amigos $\square \quad \square \quad \square \quad \square \quad \square$

c. Passatempos / meus interesses pessoais $\square \quad \square \quad \square \quad \square \quad \square$ d. Omeupais $\square \quad \square \quad \square \quad \square \quad \square$

e. A minha origem étnica (africana, europeia, indigena, ou outral

f. Dinheiro e riqueza que possa adquiri B. A minha fé religiosa h. Democracia cavaleiros e donzelas ए
22. A que você associa o periodo de colonizaç̧o?

a. Um período de grandes aventureiros (Colombo, Cabral, etc.)

b. Uma missäo cristã fora da Europa

c. Grandes impérios de algumas naçð̋es européias

d. O começo de um período de exploração

e. Um esforço Europeu para o progresso em outros continentes

f. Desprezo e preconceito com outras culturas (indigenas, negros, etc.)

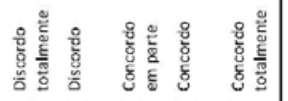

$\square$

$\square \square \square \square$

$\square \square \square$

$\square \square \square \square \square$

$\square \square \square \square \square$

$\square \square \square \square \square$

\section{A que você associa a Revolução} Industrial?

a. O começo da poluiçăa ambiental

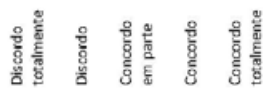

b. A origem de melhores condiçōes de vida

c. A invençăo de melhores máquinas

d. A acumulaçăo de grandes reservas de capital

e. Cidades superpovoadas e feias

f. Conflitos entre patrőes e empregados

$\square \square \square \square \square$

$\square$ c. As coisas geralmente mudam para pior.

$\square$ d. As coisas geralmente tendem a se repetir.

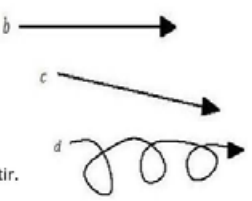

$\square$ e. As coisas geralmente vờ de um extremo ao outro.

$\square$ f. As coisas acontecem sem nenhum sentido.

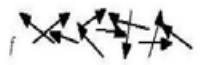

$\square$ b. As coisas geralmente não mudam. seguintes linhas você pensa que descreve melhor o desenvolvimento da história. Assinale uma opçao.

$\square$ a. As coisas geralmente mudam para melhor.

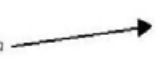

k. Solidariedade com os pobres do meu ${ }_{\text {país }} \square \quad \square \quad \square \quad \square \quad \square$

I. Solidariedade com os pobres de outros $\square \quad \square \quad \square \quad \square \quad \square$ m. Bem-estar e segurança social $\square \square \square \square \square \square$ n. Proteção do meio ambiente $\square \square \square \square \square \square$ 
27. Como você pensa que era a vida no seu país ha 40 anos?

a. Paclfica

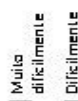

b. Explorada por um pals estrangeiro

c. Prosperae rika

d. Dêmocratica

e. Polukda

t. Agitada par prablemasentre ricas e patres

g. Agitada por conflitos pollticos

28. Como você acha que sera a vida no seu país dacul a 40 a nos?

a. Paclfica

b. Explorada por um pals estrangeiro

c. Prosperae rika

d. Democratica

e. Polukda

t. Agitada par prable mase ntre ricas e pabres

g. Agitada por conflitos pollticos

29. Como você acha que sera A SUA

VIDA dacula 40 anos?

a. Terei um trabalho prazeroso

b. Terei uma famllia felize harmoniosa

c. Terei bons amizos

d. Terei rendimentos elevados

e. Terei liberdade polltica individual

f. Participareida vida poltica

g. Tereitempo livrepara participar de

atividades interessantes de lazer

30. EM NOSSO PAIS HÁGRANDE DIFERENCA ENTRE RICOS E POBRES. OS

rloos se tornaram rlcos por que...

a. tiveram sorte

b. trabalkaram bastante

c. herdaram riquezase dinheiro

d. foram enoktase imorais

e. beneficiaram-se de um sistema econbimiko injusto

f. foram criativase / ou correram riscos. g. foram corruptos

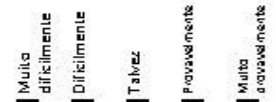

31. Imagine que voos es um homem / mulher do seculo XVII. Teu pal manda que vove se case com a fllha f fllho de um agrlcultor mak flco da cldade valnha. Imagine que vocể não ama e nem conhece seu futuro esposo fesposa. O que você farla SE ESTIVESSE NESSA ÉPOCA3 [Marcar uma alter nathap

$\square$ a. Rexusaria porque ê desumano, imoral ê ikgattimo forçar alguêm a se casar com quem nåo se ama de verdade.

$\square$ b.obedkeria, porqueo interesse exonomicos mais importante do que o amor a paikonado ent re mulher e marido.

$\square$ c. Iria para um convento ou mosteiro porque a vida religiosa \& mais digna do que a vida na sociedade comum.

$\square$ d. Aceitaria, porque quase todos $\propto$ jowenc se casam de acordo som a vontade dos $p a i$.

$\square$ e. Nă aceitaria, porque ê um direito natural do indiulduo secasar por amor.

$\square$ f. obedereria, porque desobedexer aos pais \& o mesmo que desobedkerera kei de Deus.

32. Terranova $\&$ um teritorlo Imaginarlo. Suponha que Terranosa fol ocupado pelo nosso país [A de de 1500 a 1900 . De 1900 até ho]e, Terranova fol ocupa da pelo país B. Nosso país quer Terranoua de volta e apresenta argumentos, Que Import fincla você dh aos segulmtes argumentos:
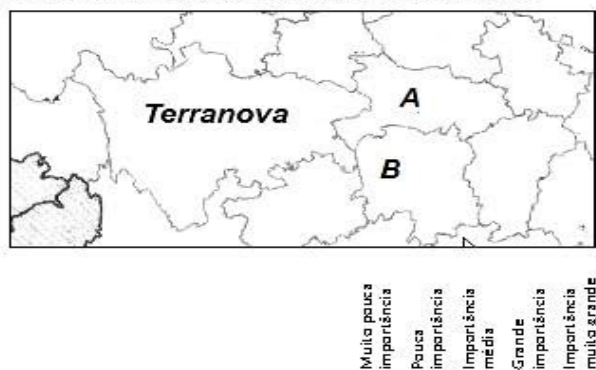

a. "O powo de Terranowa fala mossa llngua e tem nossa cultura nosso controle do que de $B^{*}$

c. "Os calanas da nassa paíse

estabe kce ram em Terranava em 1500 enquanta as da pa'ś B sá a partir de 1900*

d. Yuanda perguntados as habitantes de Terranavadisem que pretere $m$ viwer $3 a \mathrm{~b}$ nassa cantrale da que sau a cantrale de $B^{*}$

\&. "Um encontro internacional de paz examinouo caso e reconhereu o dire ito do mosso pals de ter Terranowa de wolta*

f. "Nós temos poder militare faremos uso dele para ter Terranowa de wolta*
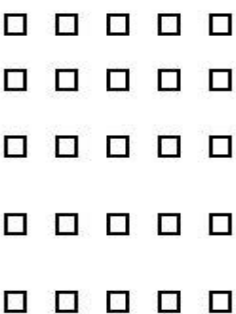

$\square \square \square \square \square$

33. ESCREYA ABAIXO O NOME DE 3 HERÓIS, ROR ORDEM DE IMPORTRNCLA PARAO SEU PAES

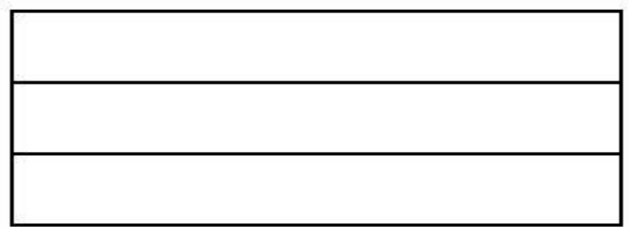

34. Imagine que um dla, no futuro, as populaçoes Indigenas ef ou descendentes de escravos reclamasse $m$ uma Indentzaça pelos males que sofreram na construção de nosso país. Quem deverá pagar? Imarcar uma alter nat hua

$\square$ a. O governo com $\propto$ im postos pagas por todos.

$\square$ b. os mais rikos do pak, que se beneficiaram da explaraça

$\square$ c. os pakes colonizadores que se beneficiaram da exploraça.

$\square$ d. Ninguém. Năose deve reconhexer o direito a essa indenizaça. 


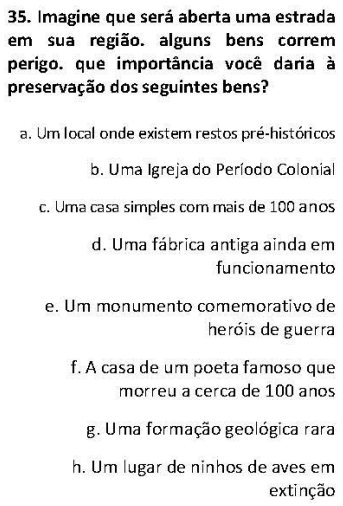

35. Imagine que será aberta uma estrada em sua região. alguns bens correm perigo. que importância você daria à preservação dos seguintes bens? funcionamento

e. Um monumento comemorativo de he róis de guerra

f. A casa de um poeta famoso que morreu a cerca de 100 anos

g. U ma formação geológica rara

h. Um lugar de ninhos de aves em exti nção

\section{QUE IDÉIAS VOCÊ TEM SOBRE AS} NACÕES E O PAÍS?

a. As naçôes nascem, crescem e morrem na História, como acontece com tudo

b. As nações são coisas naturais por uma origem, por uma língua, pela história e pela cultura

c. As naç̃es são o desejo da crỉação de um futuro, apesar das diferenças culturais do passado

d. Os países devern ceder parte da sua soberania a organismos internacionais (como a ONU, O MERCOSUL)

e. Os interesses do meu país devem ser defendidos a todo custo, inclusive por força militar

37. O que você pensa da democracia?

a. É o governo do povo, para o povo e pelo povo

b. É a melhor herança da Grécia Antiga c. É o resultado de um longo processo de experiências e erros ao longo dos tempos d. Nâo passa da aclamação de alguns líderes partidários em eleições

e. É governar em obediência da le $\mid$ e da justiça, e em proteção das minorias

f. Deverỉa incluir a proteção aos mais pobres e a garantia de emprego g. É um sistema de governo fraco que nâo serve em tempos de crise

h. É uma falsa aparência que encobre o fato de sempre serem os ricos que vence m na história

i. Nâo é autêntica enquanto homens e mulheres năo tiverem direitos iguais em todas as situaçôes
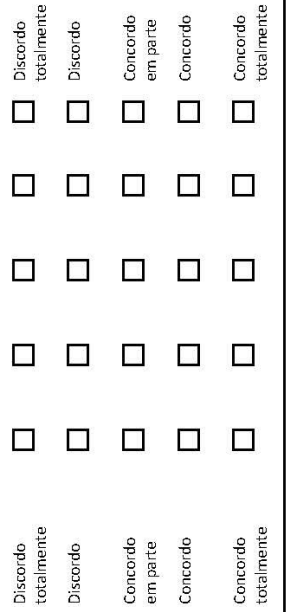

$\square \square \square \square \square$

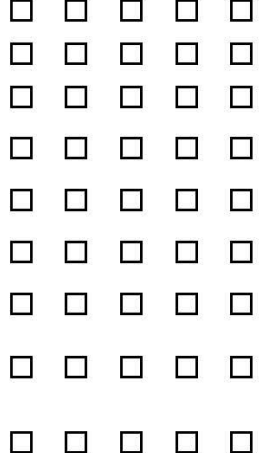

38. Como são os jovens de nosso pais? Marque apenas uma alternativa, a que você considerar mais importante.

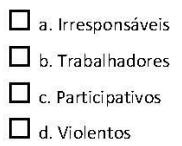

$\square$ e. Criativos

$\square$ f. Comprometidos

$\square$ g. Individualistas

$\square$ h. Solidários
39. Marque o seu grau de concordância com as afirmações abaixo.

a. Deve haver responsabilidade igual do homem e da mulher no cuidado com os filhos e no trabalho doméstico

b. Eu aceito ter amigos e amigas homossexuais

c. Para mim não há problemas em ter amigos de outras religiões d. A mulher sempre teve um papel importante nas conquistas e lutas da história

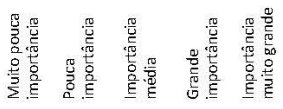

0. Sobre os processos de integração da América do Sul, que importância tem o seguinte:

a. Acordos para aumentar o comércio entre os

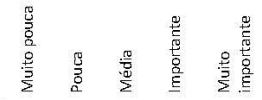
países

b. Programas que facilitem que os cidadãos estudem e trabalhem em outros paises da região

c. Construção de estradas, ferrovias, gasodutos e obras que conectem os países do continente d. Iniciativas que promovam uma integração mais so idária entre os povos da região

e. Iniciativas que dêem mais acesso a livros, filmes e músicas produzidas em outros países da América do Su

\section{OS TEMAS A SEGUIR SÃo POLÊMICOS. EM QUE VOCÊ VOTARIA A FAVOR OU CONTRA?}

a. Maior controle sobre o trânsito de veículos para diminuir os acidentes e preservar o meio a mbiente

b. Intervenção do governo na economia para garantir emprego para todos

c. Ple na igualdade entre homens e mulheres no trabalho, na administração da casa e na política d. Distribuiçâo de terra para os mais pobres, mesmo que signifique diminuir as propriedades dos mais

e. Açôes para que, no futuro, a América Latina seja um únicopaís

f. Integração econômica do MERCOSUL, incluindo uma moeda comum

g. Preservação do meio ambiente, mesmo que isso prejudique o desenvolvimento econômico

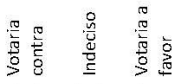

41. Marque apenas uma altemativa, a que você considerar mais importante: em sua opinião, a juventude deve:
$\square$ a. Lutar por suas ideias/ideais
$\square$ b. Divertir-se e curtir a vida
$\square$ c. Formar-se para ofuturo
$\square$ d. Assumir responsabilidades trabalhando
$\square$ e. Definir objetivos de vida para si

43. Os governos militares em nosso pais podem ser ligados a:

a. Manutenção da ordem e combate ao terrorismo.

b. Intenso desenvolvimento econômico.

c. Tortura e assassinato de opositores.

d. Nâo levar em conta a opiniâo do povo para governar.

e. Crises econômicas e aumento da divida externa.

f. Um periodo de maior segurança pública ricos

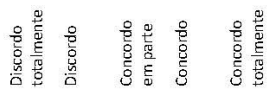

\section{京}
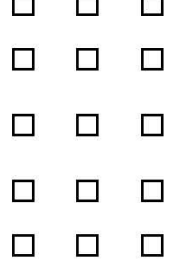

$\square \square \square \square \square$

$\square \square \square \square \square$

$\square \square \square \square \square$

$\square \square \square \square \square$

$\square \square \square \square \square$ 
E: T. N.Q.

\section{Os jovens e a História - Brasil Questionário de professores}

\section{BLOCO 1 - PERFIL}

Idade: Sexo: $\square$ Masculino Feminino

1. Qual a sua formação docente? (marcar uma alternativa)

Outro curso superior que não de formação de professores de História.

Curso superior de formação de professores de História.

Não possuo curso superior.

2 - Qual é a instituição de sua última formação? (Escreva com letra de forma.)

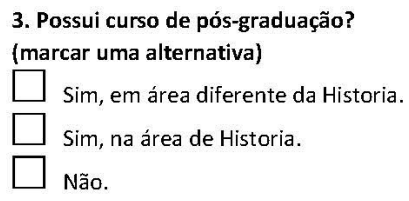

4. Há quanto tempo concluiu sua formação para lecionar, incluindo o corrente ano? (marcar uma alternativa)

$\square$ Até 3 anos

$\square$ De 4 a 8 anos

$\square$ De 9 a 15 anos

$\square$ De 16 a 25 anos

26 anos ou mais

5. Qual sua experiência como professor (a),incluindo o corrente ano? (marcar uma alternativa)

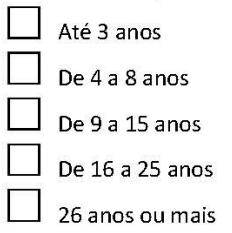

6. Em sua opinião, qual é a importância da História na formação dos seus alunos para a vida? (marcar uma alternativa

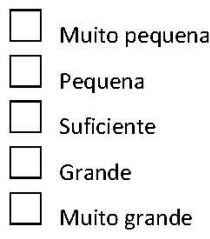

7. Dos problemas abaixo, quais estão presentes na região em que sua escola está:

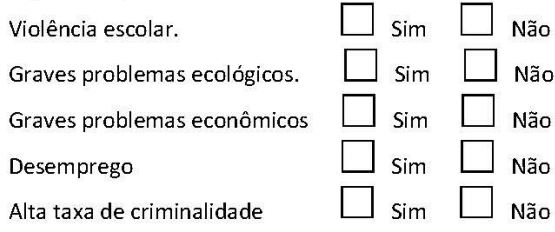

8. O que a religião significa para você? (marcar uma alternativa)

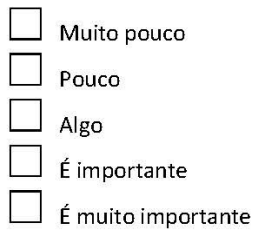

9. Qual seu interesse pela política? (marcar uma alternativa)

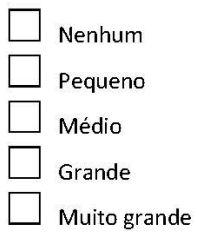

10. Sobre sua participação em política (marcar uma alternativa):
$\square$ Nunca participo
$\square$ Participo raramente
$\square$ Participo às vezes
$\square$ Participo
Participo frequentemente 
11. Nas eleições, você geralmente vota em candidatos e partidos: (marcar uma alternativa)

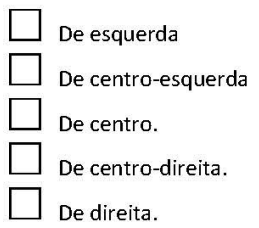

\section{BLOCO II. ENSINO E APRENDIZAGEM DA HISTÓRIA}

12. Como você avalia o grau de aprendizagem dos alunos sobre os seguintes assuntos:

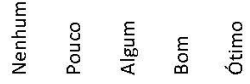

a. História Antiga.

b. Idade Média.

c. Revolução Industrial.

d. Adolf Hitler e a 2 a Guerra

Mundial.

e. Independência Nacional.

f. Formação do Estado Moderno.

g. Historia de outros países da América Latina.

h. Ditadura Militar.

i. Globalização.

j. Democracia.

13. O que normalmente acontece em durante as aulas de História?

a. Os estudantes ouvem as minhas exposições sobre o passado.

b. Os alunos são informados do que foi bom ou mau, certo ou errado na História.

c. Eles discutem diferentes explicações sobre o que aconteceu no passado.

d. Eles pesquisam diversas fontes históricas: documentos,

fotografias, figuras, mapas. e. Eles recordam e reinterpretam a História.

f.Eles ouvem fitas, CD's ou vemos filmes e vídeos sobre História.

g.Eles usam livros escolares, apostilas ou algum outro material (fotocopia).

h. Eles participam de atividades em grupo: encenações de teatro visita a museus, projetos com a comunidade.

14. Nas suas aulas, quais em quais objetivos você concentra o ensino de História

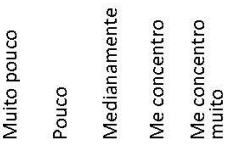

a. Eu quero que os meus alunos adquiram conhecimento sobre os principais fatos da História.

b. Eu quero que eles julguem moralmente os conhecimentos históricos de acordo com os direitos civis e humanos.

c. Eu quero que eles imaginem o passado tomando em consideração todos os pontos de vista.

d. Eu quero que eles compreendam o comportamento das pessoas no passado, reconstruindo os quadros de vida e pensamento do período em que essas pessoas viveram.

e. Eu quero que eles usem a História para explicar a situação do mundo atual e descobrir a tendências de mudança.

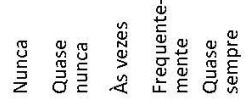

f. Eu quero que eles aprendam a reconhecer as tradições, características, valores e missão da nossa nação e sociedade.

g. Eu quero que eles aprendam a valorizar a preservação dos locais históricos e construções antigas.

h. Eu quero que eles estudem história de forma divertida $e$ fascinante.

i. Eu quero que eles interiorizem valores democráticos básicos. 
15. Quais os temas da história mais interessam aos seus alunos?

a. A vida cotidiana das pessoas comuns.

b. Reis, rainha e outras pessoas importantes.

c. Aventureiros e grandes descobridores.

d. Guerras e ditaduras.

e. Culturas de outros países e distantes.

f. A formação das nações.

g. O desenvolvimento da democracia.

h. A interferência do homem no meio-ambiente.

i. O desenvolvimento da agricultura, da indústria e do comércio.

j. A história de assuntos específicos (por exemplo: a história dos carros, da Igreja, da música, do esporte, etc.).

k. A história da sua família.

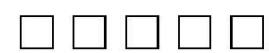

16. Quais afirmações melhor descrevem os problemas do professor de História no seu pais?

a. Não existem possibilidades suficientes para obter melhor qualificação.

b. Há súbitas e profundas mudanças políticas na interpretação da história.

c. Há poucas aulas de História no
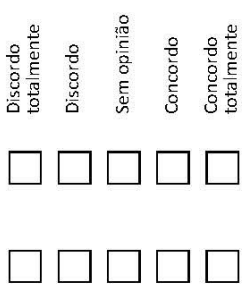

$$
\text { currículo escolar. }
$$

d. Há uma carencia de apoioe

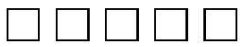

d. Há uma carência de apoio e materiais de ensino.

e. Falta de interesse por parte dos estudantes.

f. Pressão por parte da Secretaria / Ministério da Educação.

g. Existem muitas mudanças curriculares na disciplina.

h. Não há tempo suficiente para preparação da aulas.

i. Baixos salários.
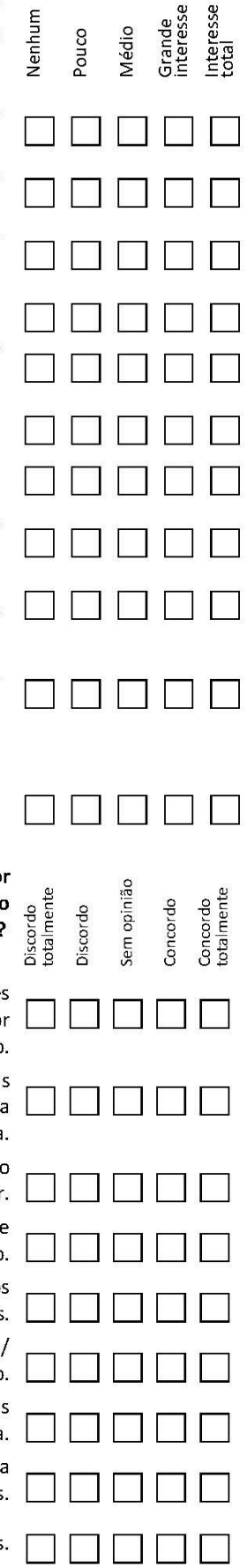

\section{BLOCO III. PASSADO, PRESENTE E FUTURO}

17. Que influência você acha que tiveram os seguintes fatores na mudança da vida das pessoas desde 1970 até hoje?

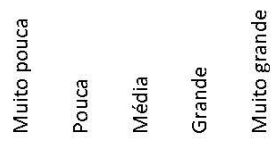

a. Invenções técnicas e mecanização

b. Movimentos e conflitos sociais

c. Reis, presidentes $e$ personagens politicamente

importantes no poder

d. Reformas políticas

e. Fundadores de religiões e chefes religiosos

f. Desenvolvimento da ciência e do conhecimento

g. Guerras e conflitos

h. Interesses econômicos concorrência econômica

i. Filósofos, pensadores e pessoas instruídas

j. Revoluções políticas

k. Problemas ambientais

I. Migrações

m. Organização dos trabalhadores

n. Esforço pessoal

o. Cientistas e engenheiros
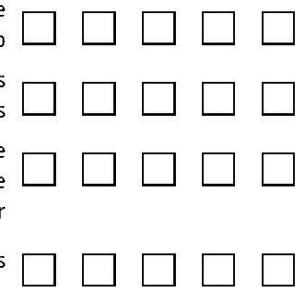

e

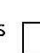

$\square$
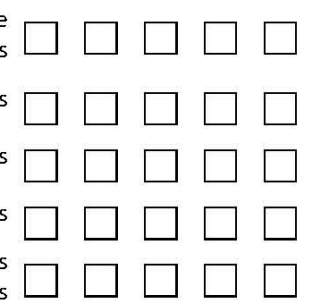


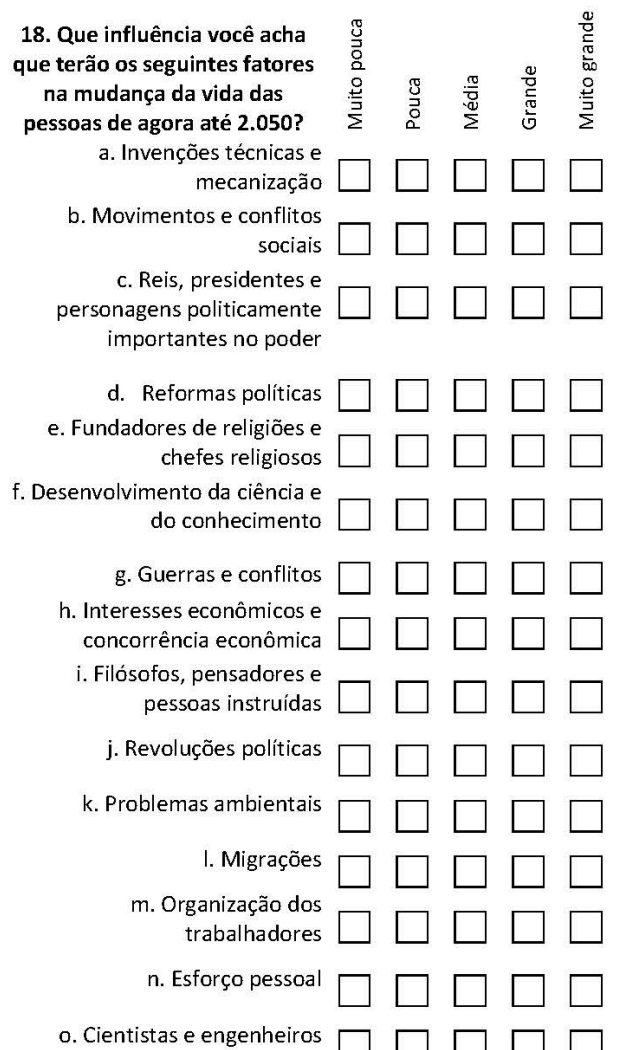

19. Marque o seu grau de concordância com as afirmações abaixo.

a. Deve haver responsabilidade igual do homem e da mulher no cuidado com os filhos e no trabalho doméstico

b. Eu aceito ter amigos e amigas homossexuais

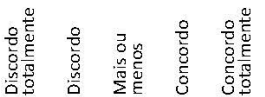

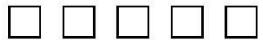

mim não há problemas em ter amigos de outras religiões

d. A mulher sempre teve um papel importante nas conquistas e lutas da história
20. Sobre os processos de integração da América do Sul, que importância tem o seguinte:

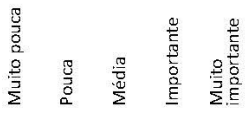

a. Acordos para aumentar o comércio entre os paises

b. Programas que facilitem que os cidadãos estudem e trabalhem em outros países da região

c. Construção de estradas, ferrovias, gasodutos e obras que conectem os países do continente

d. Iniciativas que promovam uma integração mais solidária entre os povos da região

e. Iniciativas que deem mais acesso a livros, filmes e músicas produzidas em outros países da América do Sul

\section{Os governos militares em nosso país podem ser ligados a:}

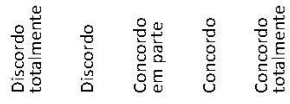

a. Manutenção da ordem e combate ao terrorismo.

b. Intenso desenvolvimento econômico.

c. Tortura e assassinato de opositores.

d. Não levar em conta a opinião do povo para governar.

e. Crises econômicas e aumento da dívida externa.

f. Um período de maior segurança pública

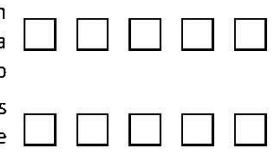




\section{SOBRE OS AUTORES}

Cristiani Bereta da Silva - Doutora em História. Professora do Departamento de História, do Programa de Pós-Graduação em História, do Programa de PósGraduação em Educação e do Mestrado Profissional em Ensino de História da Universidade do Estado de Santa Catarina (UDESC). Bolsista de produtividade em pesquisa do CNPq. E-mail: cristianibereta@gmail.com.

Luciana Rossato - Doutora em História. Professora do Departamento de História, do Programa de Pós-Graduação em História e do Mestrado Profissional em Ensino de História da Universidade do Estado de Santa Catarina (UDESC). E-mail: lucianarossato1972@gmail.com

Nucia Alexandra Silva de Oliveira - Doutora em História. Professora do Departamento de História, do Programa de Pós-Graduação em História e do Mestrado Profissional em Ensino de História da Universidade do Estado de Santa Catarina (UDESC). E-mail: nucia.oliveira@gmail.com.

Marizete Lucini - Doutora em Educação. Professora da Universidade Federal de Sergipe. Programa de Pós-Graduação em Educação - PPGED/UFS e Programa de Pós-Graduação Mestrado Profissional em Ensino de História UFRJ/UFS. Líder do Grupo de Pesquisa em História, Educação e Interculturalidade. E-mail: marizetelucini@gmail.com.

Lana M. de C. Siman - Professora da Faculdade de Educação e do Programa de Pós-Graduação em Educação da Universidade do Estado de Minas Gerais (UEMG). Correio eletrônico: lanacastrosiman@gmail.com.

Herbert de Oliveira Timóteo - Professor de História da Rede Municipal de Belo Horizonte. Mestre em Educação pela Faculdade de Educação da Universidade do Estado de Minas Gerais (FAE/UEMG). Correio eletrônico: herbert.timoteo@ gmail.com. 
João Andrade - Professor de História nas Redes Municipais de Belo Horizonte e Betim. Mestre em Educação pela Faculdade de Educação da Universidade do Estado de Minas Gerais (FAE/UEMG). Correio eletrônico: andrade1968@gmail. com.

Mariano A. Diniz Filho - Professor de História da Rede Municipal de Belo Horizonte. Mestre em Educação pela Faculdade de Educação da Universidade do Estado de Minas Gerais (FAE/UEMG). Correio eletrônico: marianodiniz@ gmail.com.

Caroline Pacievitch - Caroline Pacievitch - Licenciada em História e Mestre em Educação pela UEPG. Doutora em Educação pela Unicamp. Professora da Faculdade de Educação da UFRGS. Correio eletrônico: pacievitch@gmail.com.

Flávia Eloisa Caimi - Doutora em Educação pela Universidade Federal do Rio Grande do Sul. Pós-Doutora em Educação pela Flacso-Argentina. Professora titular do Curso de História e membro do corpo docente permanente do Programa de Pós-Graduação em Educação da Universidade de Passo Fundo. E-mail caimi@upf.br.

Letícia Mistura - Mestranda em Educação pela Universidade de Passo Fundo. Bolsista CAPES. Correio eletrônico: leticiamistura@gmail.com.

Federico Alvez Cavanna - Professor de História pelo Instituto de Profesores Artigas -IPA (Montevideo, 2001), mestre em Educação pela UEPG (2009) e doutor em História pela UFPR (2013). É professor adjunto da Universidade Estadual do Paraná (UNESPAR) no Campus de Paranaguá e no Programa de Pós-Graduação Mestrado Prof-História da UNESPAR. Correio eletrônico: federico.alvez@unespar.edu.br.

Gabriel Quirici - Professor de História pelo Instituto de Profesores Artigas - IPA (Montevideo, 2001). Diplomado em História Econômica pela Facultad de Ciencias Sociales (FCS) da Universidad de la República - Udelar (2008). É professor de História Contemporânea na FCS e na Facultad de Comunicación e Información 
(Udelar) e de Historia del Uruguay III (1830-1930) no IPA. Correio eletrônico: gquirici@gmail.com.

Léia Adriana da Silva Santiago - Graduada em História pela Universidade Federal de Santa Catarina, mestre (UFSC) e doutora (UFPR) em Educação, com pós-doutorado na Universidade Autônoma de Barcelona. Professora do Instituto Federal de Ciência e Tecnologia Goiano, no mestrado profissional em Educação Profissional e Tecnológica (ProfEPT). Correio eletrônico: leia.adriana@ifgoiano. edu.br.

Wilian Carlos Cipriani Barom - Doutor em Educação pela UEPG. Professor da Rede Estadual de Educação do Paraná e professor colaborador no Departamento de História da UEPG. Correio eletrônico: wilianbarom@yahoo. com.br.

Renilson Rosa Ribeiro - Doutor em História Cultural pela Universidade Estadual de Campinas (Unicamp). Realiza atualmente estágio pós-doutoral em Educação na Faculdade de Educação da Universidade de São Paulo (USP), sob a supervisão de Kátia Maria Abud. Professor Associado I do Departamento de História, Programa de Pós-Graduação em História e ProfHistória - Mestrado Profissional em Ensino de História da Universidade Federal de Mato Grosso (UFMT). Correio eletrônico: rrrenilsoon@yahoo.com.

Luís César Castrillon Mendes - Doutor em História pela Universidade Federal de Mato Grosso (UFMT). Realiza atualmente estágio pós-doutoral em Letras pela mesma instituição, sob a supervisão de Danie Marcelo de Jesus. Professor Adjunto A-I do Curso de História da Universidade Federal da Grande Dourados (UFGD). Correio eletrônico: Icesar69@yahoo.com.br.

Osvaldo Rodrigues Junior - Doutor em Educação pela Universidade Federal do Paraná (UFPR). Professor Adjunto I do Departamento de História, Programa de Pós-graduação em História e ProfHistória - Mestrado Profissional em Ensino de História da Universidade Federal de Mato Grosso (UFMT). Correio eletrônico: osvaldo.rjunior@gmail.com. 
Luis Fernando Cerri - Doutor em Educação pela UNICAMP. Professor Associado do Departamento de História da UEPG e docente do Programa de Pós-Graduação em Historia e do Mestrado Profissional (ProfHistória) na mesma instituição. É líder do Grupo de Estudos em Didática da História. Correio eletrônico: Ifcronos@yahoo.com.br.

\section{Sobre o livro}

$\begin{aligned} \text { Formato } & 16 \times 23 \mathrm{~cm} \\ \text { Tipologia } & \text { Chaparral Pro 11pt } \\ \text { Papel } & \text { Offset 75g (miolo) } \\ & \text { Cartão Supremo 250g (capa) } \\ \text { Impressão } & \text { Gráfica Copiart } \\ \text { Acabamento } & \text { Colado, costurado com laminação fosca e } \\ & \text { shrink individual } \\ \text { Tiragem } & 200 \text { exemplares } \\ \text { Ano } & 2018\end{aligned}$

